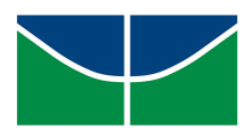

UNIVERSIDADE DE BRASÍLIA

INSTITUTO DE ARTES

DEPARTAMENTO DE ARTES VISUAIS

PROGRAMA DE PÓS-GRADUAÇÃO EM ARTE

\title{
NARRATIVA VISUAL DOS ALUNOS DA EDUCAÇÃO DE JOVENS E ADULTOS NA PERSPECTIVA DA CULTURA VISUAL
}

Margarida Helena Camurça Martins

Orientação: Professora Doutora Thérèse Hofmann Gatti Rodrigues da Costa

Dissertação de Mestrado

Brasília-DF, dezembro de 2016 


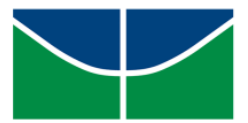 \\ UNIVERSIDADE DE BRASÍLIA \\ INSTITUTO DE ARTES \\ DEPARTAMENTO DE ARTES VISUAIS \\ PROGRAMA DE PÓS-GRADUAÇÃO EM ARTE}

Margarida Helena Camurça Martins

NARRATIVA VISUAL DOS ALUNOS DA EDUCAÇÃO DE JOVENS E ADULTOS NA PERSPECTIVA DA CULTURA VISUAL

Dissertação apresentada ao Programa de PósGraduação em Artes Visuais da Universidade de Brasília, como requisito parcial para a obtenção do título de Mestre, em Arte na linha de pesquisa de Educação em Artes Visuais.

Orientação: Professora Doutora Thérèse Hofmann Gatti Rodrigues da Costa 


\section{MARTINS Camurça Helena, Margarida.}

Narrativa visual dos alunos da Educação de Jovens e Adultos na perspectiva da cultura visual - Margarida Helena Camurça Martins, 2016.

223 fls.

Orientação: Thérèse Hofmann Gatti Rodrigues da Costa

Dissertação (Mestrado), Universidade de Brasília, Instituto de Arte, Departamento de Artes Visuais, Programa de Pós-Graduação em Arte. Brasília-DF, 2016.

1. Narrativa Visual; 2. Educação de Jovens e Adultos; 3. Cultura Visual. I. Thérèse Hofmann; II. Titulo. 


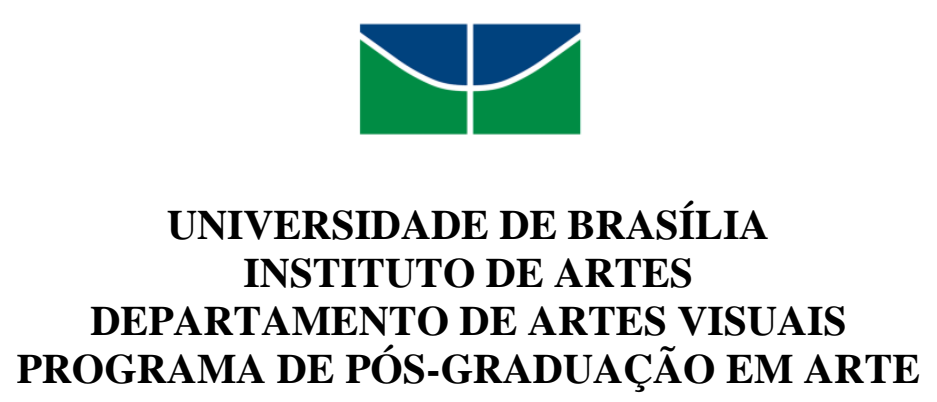

Dissertação de Mestrado - NARRATIVA VISUAL DOS ALUNOS DA EDUCAÇÃO DE JOVENS E ADULTOS NA PERSPECTIVA DA CULTURA VISUAL, aprovada em 12 de dezembro de 2016 pelos (as) Professores (as):

Profa. Dra. Thérèse Hofmann Gatti Rodrigues da Costa Orientadora (IdA / UnB)

Profa. Dra. Maria Helena da Silva Carneiro Examinadora Interna (FE / UnB)

Prof. Dr. Raimundo Martins da Silva Filho Examinador Externo - Universidade Federal de Goiás

Prof. Dr. Luiz Carlos Pinheiro Ferreira Examinador Suplente (IdA / UnB) 


\section{Dedicatória}

À Maria Margarida Camurça Martins, mãe guerreira, responsável por minha educação e formação dos valores éticos. Aos meus filhos Pedro e Mariana e netos pelo apoio, carinho e respeito. 


\section{AGRADECIMENTOS}

Aos diretores Nedma Guimarães do Centro Educacional 01 de Planaltina e Divaldo de Oliveira do Centro de Ensino Médio 03 de Ceilândia, pelo acolhimento em suas instituições educacionais.

Aos professores de Arte Nitiana Ribeiro do CED 01 de Planaltina e Ney Cirqueira do CEM 03 de Ceilândia, por abraçarem a pesquisa com seus 38 alunos e por cederem os espaços de suas curtas aulas de Arte.

Aos alunos do CED de 01 de Planaltina e do CEM 03 de Ceilândia, com seus olhares sensíveis e afetivos nos ofereceram sua visão de como olham, se olham e como produzem suas respectivas cidades. Com a participação e compartilhamento de suas histórias de vida me fizeram avivar lembranças de mim mesma e me fizeram lembrar de Paulo Freire ao afirmar: "Ninguém educa ninguém, ninguém educa a si mesmo, os homens se educam entre si mediatizados pelo mundo".

A minha orientadora Thérèse Hofmann, pelas orientações que propiciaram a mudança no percurso da pesquisa, principalmente, pela paciência em receber a todo e qualquer momento e pelos questionamentos que me impulsionaram a buscar as respostas na minha prática educativa.

Aos meus filhos Pedro e Mariana, pelas revisões e traduções dos textos em inglês, e pelo apoio técnico computacional. Ao José Angelo Belloni, companheiro de todas as horas, pelas sugestões estatísticas, como também às minhas amigas Paula, Eleuza e Márcia pelas valiosas contribuições de leituras e revisões.

Aos professores e colegas do Instituto de Arte, em especial: Professor Belidson e os colegas Cleber Xavier e Leísa Sasso pelas dicas de leituras. 
66 Sou feita de retalhos. Pedacinhos...

Sou feita de retalhos.

Pedacinhos coloridos de cada vida que passa pela minha e que vou costurando

na alma.

Nem sempre bonitos, nem sempre felizes, mas me acrescentam e me fazem ser quem eu sou.

Em cada encontro, em cada contato, vou ficando maior... Em cada retalho, uma vida, uma lição, um carinho, uma saudade...

Que me tornam mais pessoa, mais humana, mais completa.

E penso que é assim mesmo que a vida se faz: de pedaços de outras gentes que vão se tornando parte da gente também. E a melhor parte é nunca estaremos prontos, finalizados... Haverá sempre um retalho novo para adicionar à alma.

Portanto, obrigada a cada um de vocês, que fazem parte da minha vida e que me permitem engrandecer minha história com os retalhos deixados em mim. Que eu também possa deixar pedacinhos de mim pelos caminhos e que eles possam ser parte das suas histórias.

E que assim, de retalho em retalho, possamos nos tornar, um dia, um imenso bordado de "nós". 


\section{RESUMO}

A dissertação intitulada "Narrativa visual dos alunos da Educação de Jovens e Adultos na perspectiva da cultura visual" consiste numa reflexão acerca das narrativas visuais produzidas pelos alunos da Educação Básica, da Educação de Jovens e Adultos da rede pública do Distrito Federal. A pesquisa foi realizada em duas Regiões Administrativas: Planaltina e Ceilândia com o intuito de apreender as representações visuais dos alunos e refletir sobre como as visualidades presentes no cotidiano afetam a leitura do mundo e como essa leitura é influenciada pela experiência de vida do aluno. Para isso, foram elencados os seguintes objetivos: apreender a narrativa visual dos alunos na sua relação com o espaço urbano, refletir como os alunos veem a cidade onde vivem e compreender se as visualidades cotidianas afetam a leitura de mundo e como essa leitura é influenciada pela experiência de vida do aluno. O trabalho foi desenvolvido em dois Centros Educacionais da rede pública que ofertam a Educação de Jovens e Adultos, entre os meses de setembro a dezembro de 2015. A pesquisa se caracteriza pela abordagem qualitativa, utilizando como instrumentos metodológicos um questionário, composto de trinta e sete perguntas, para identificar o perfil dos alunos e um portfólio individual para organização das narrativas visuais integrado a uma dinâmica da árvore, formulário com indicações dos sonhos e perspectivas futuras. A apreensão das narrativas ocorreu em três momentos: "Lugares de lembrar a infância"; "Lugares de lembrar a cidade e sua inserção" e "Lugares de sonhar: perspectivas futuras". As produções resultaram na organização de portfólios individuais, com as narrativas visuais dos alunos com suas reminiscências da infância, perpassando a visão contemporânea da cidade e finalizando com a projeção futura. O estudo teve como referência as teorias desenvolvidas pela cultura visual, fundamentada na percepção de que as imagens contam histórias e carregam significados que são culturalmente construídos e que influenciam o nosso modo de ver e narrar o mundo. Participaram de todo procedimento metodológico oito alunos do Centro Educacional 01 de Planaltina e treze do Centro de Ensino Médio de Ceilândia, totalizando vinte e uma narrativas visuais, nas quais reverberam as experiências de vida, contadas a partir das produções de desenhos, textos, colagens de recortes de revistas e jornais; deixando evidente que a compreensão das visualidades, como práticas pedagógicas permitiram a problematização de si e do meio que nos cerca.

Palavras Chave: Narrativa Visual; Educação de Jovens e Adultos; Cultura Visual. 


\begin{abstract}
The dissertation entitled "Visual narrative of the pupils of the Youth and Adults Education in the perspective of the visual culture" consists of a reflection about the visual narrative produced by the pupils of the Basic Education and Youth and Adults Education of the public education of Distrito Federal. The research was conducted in two administrative regions: Planaltina and Ceilândia in order to grasp the visual representations of the students and reflect on how the visual arts in the daily routine affect the insight of the world and how this insight is influenced by the student's life experience. For this, the following objectives were listed: grasp the student's visual narrative in their relationship with the urban space, understand how students see the city where they live and reflect on the influence of the visual arts in the way of seeing and narrate the spaces where they live. The study was conducted in two public educational centers that offers Youth and Adult Education, between the months of September to December in 2015. The research is characterized by a qualitative approach, using a questionnaire consisting of thirty-seven questions as methodological tool to identify the student's profile and an individual portfolio to organize the visual narratives within a dynamic tree, and a form indicating dreams and future perspectives. The narratives seizure happened in three stages: "Places to remember childhood"; "Places to remember the city and its insertion" and "Places to dream: the way future perspective". The productions resulted in the organization of individual portfolios with the students' visual narratives with their childhood reminiscences, permeating the contemporary view of the city and ending with the future projection. The study had as reference to the theories developed by visual culture, based on the consciousness that the images tell stories and carry meanings that are culturally constructed and that influence our way of seeing and describing the world. Throughout the methodological procedure eight students from Centro Educacional 01 in Planaltina and thirteen from Centro de Ensino Médio in Ceilândia participated, which was twenty-one visual narratives in which they blazed their life experiences. Described using drawings, texts, clipping collages from magazines and newspaper; making it clear that the understanding of the visual arts as pedagogical practices allows questioning themselves and the environment around them.
\end{abstract}

Keywords: Visual Narrative; Youth and Adult Education; Visual Culture. 


\section{SUMÁRIO}

INTRODUÇÃ

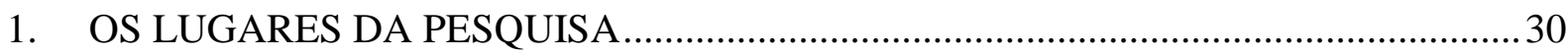

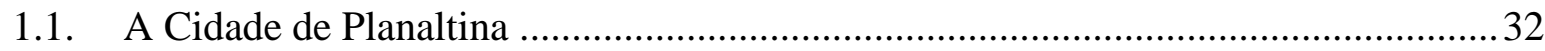

1.1.1. A Escola - Centro Educacional 01 de Planaltina “Centrão" ................................ 36

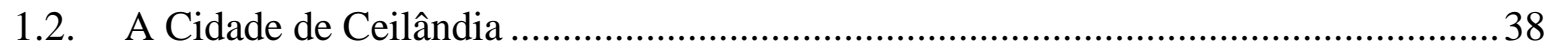

1.2.1. A Escola - Centro de Ensino Médio 03 de Ceilândia........................................... 41

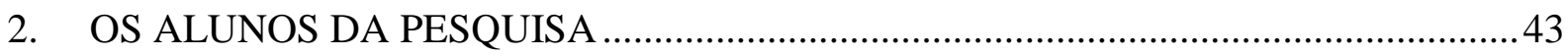

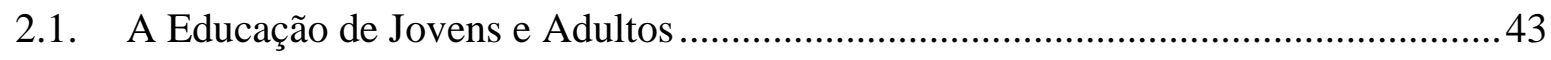

2.2. Percurso da Pesquisadora - CED 01 de Planaltina ............................................... 47

2.3. Percurso da Pesquisadora - CEM 03 de Ceilândia ..................................................50

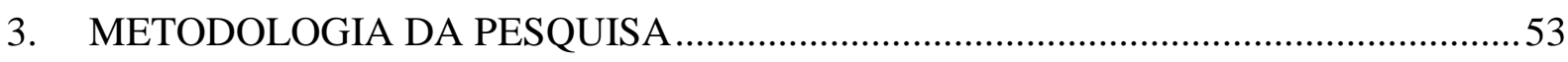

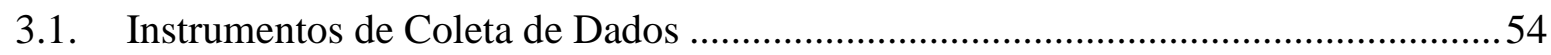

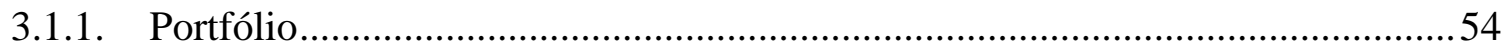

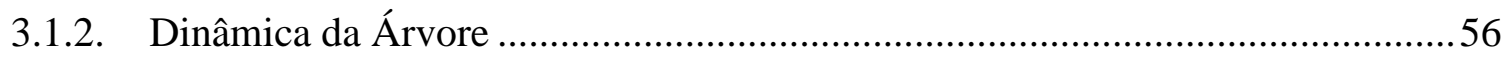

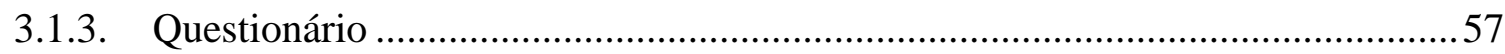

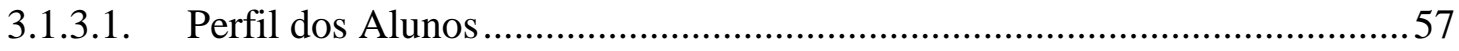

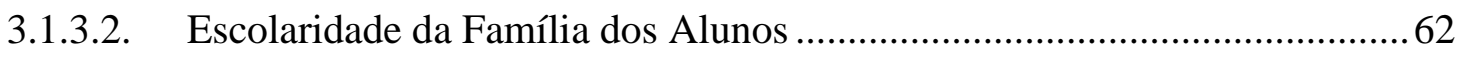

3.1.3.3. Formação Educacional e Profissional dos Alunos ...................................... 64

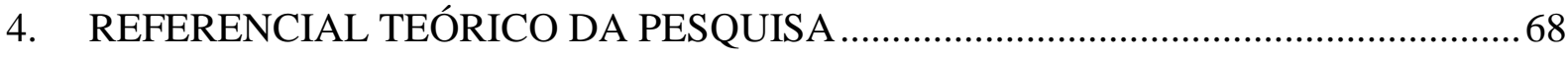

4.1. Contribuições das Teorias acerca do Conhecimento ..............................................6 68

4.2. Aproximações Epistemológicas de Freire e Vigostky .......................................... 71

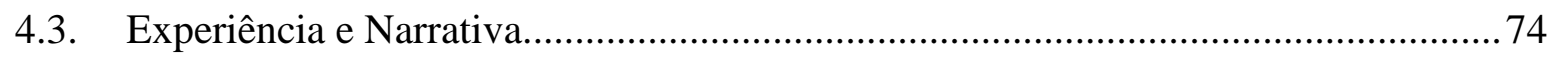

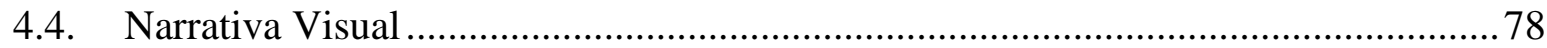

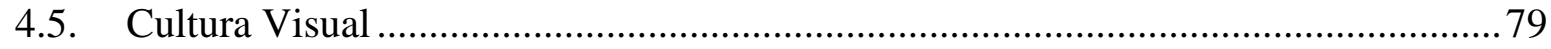

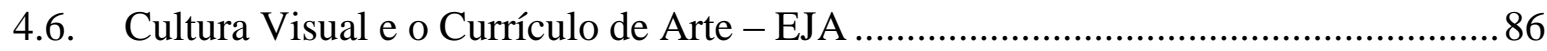

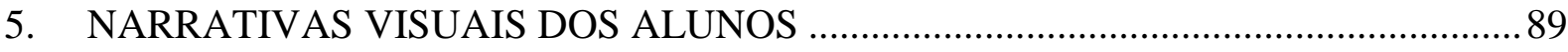


5.1. Narrativa Visual dos Alunos - CED 01 de Planaltina .92

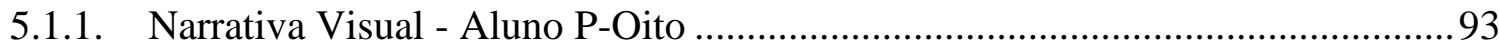

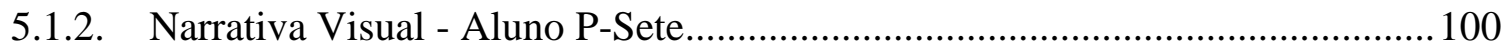

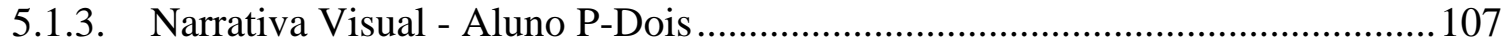

5.1.4. Narrativa Visual - Aluno P-Três ..................................................................... 113

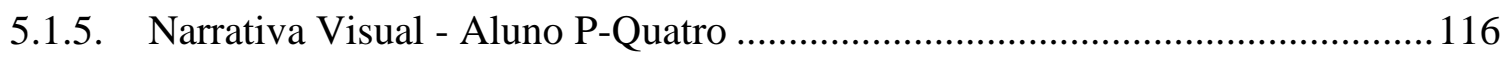

5.1.6. Narrativa Visual - Aluno P-Cinco ................................................................ 121

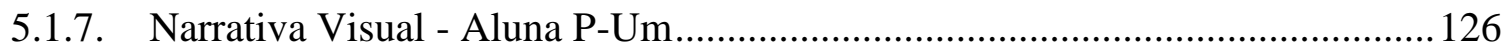

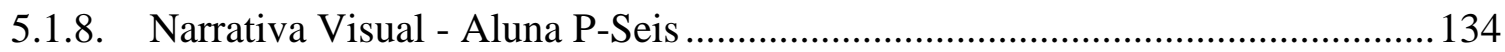

5.2. Narrativa Visual dos Alunos - CEM 03 de Ceilândia.............................................. 140

5.2.1. Narrativa Visual - Aluno C-Treze …........................................................... 140

5.2.2. Narrativa Visual - Aluno C-Dez................................................................. 147

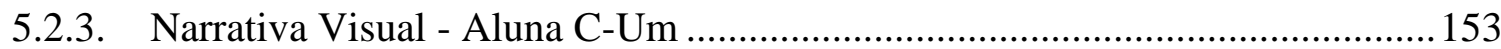

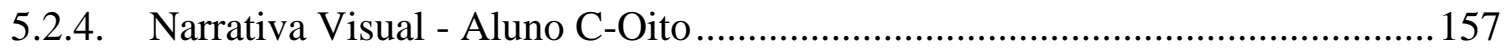

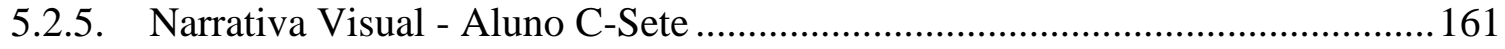

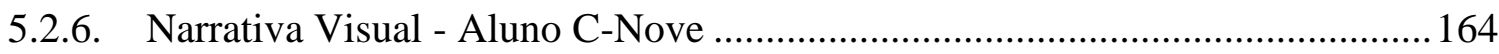

5.2.7. Narrativa Visual - Aluna C-Três …................................................................. 168

5.2.8. Narrativa Visual - Aluna C-Doze ................................................................... 171

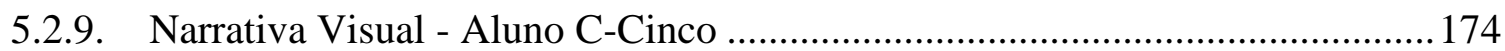

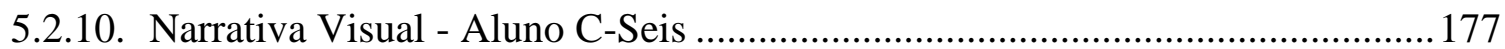

5.2.11. Narrativa Visual - Aluno C-Quatro ................................................................. 181

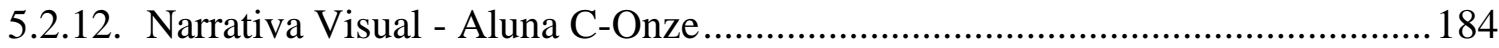

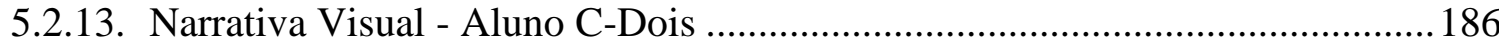

6. COSTURANDO AS NARRATIVAS VISUAIS DOS ALUNOS ................................192

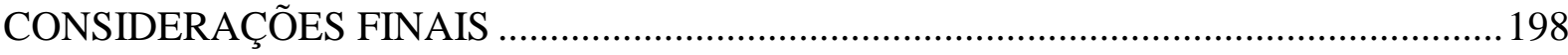

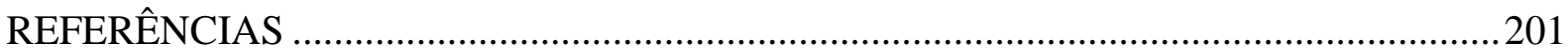

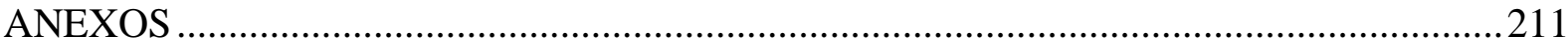




\section{LISTA DE FIGURAS}

Figura 1. Irmãos, 1968 - acervo da autora. Brasília-DF, 2015 …...........................................2 23

Figura 2. Mapa do Distrito Federal. Brasília-DF, 2016 ........................................................ 28

Figura 3. Gráfico - População do DF segundo a naturalidade. Brasília-DF, 2016................... 31

Figura 4. Mapa - Região Administrativa de Planaltina (RA VI). Distrito Federal, 2015........ 35

Figura 5. Muro: Entrada Principal - acervo da autora. CED 01 de Planaltina-DF, 2015......... 37

Figura 6. Muro: CENTRÃO - acervo da autora. CED 01 de Planaltina-DF, 2015.................. 37

Figura 7. Muro: PLANALTINA - acervo da autora. CED 01 de Planaltina-DF, 2015 .......... 37

Figura 8. Muro: YONG - acervo da autora. CED 01 de Planaltina-DF, 2015. ......................... 37

Figura 9. Espelho - acervo da autora. CED 01 de Planaltina-DF, 2015 ................................. 38

Figura 10. Mapa - Região Administrativa de Ceilândia (RA IX). Distrito Federal, 2015 .......40

Figura 11. Muro: Entrada Principal - acervo da autora. CEM 03 de Ceilândia-DF, 2015....... 42

Figura 12. Muro: Paulo Freire - acervo da autora. CEM 03 de Ceilândia-DF, 2015.............. 42

Figura 13. Muro: Immanuel Kant - acervo da autora. CEM 03 de Ceilândia-DF, 2015..........42

Figura 14. Interior da Escola - acervo da autora. CEM 03 de Ceilândia-DF, 2015. ................42

Figura 15. Sala de Aula - acervo da autora. CED 01 de Planaltina-DF, 2015 ........................49

Figura 16. Turma - acervo da autora. CED 01 de Planaltina-DF, 2015 .................................. 49

Figura 17. Sala de Aula - acervo da autora. CEM 03 de Ceilândia-DF, 2015 ........................52

Figura 18. Sala de Aula - acervo da autora. CEM 03 de Ceilândia-DF, 2015........................52

Figura 19. Confraternização - acervo da autora. CEM 03 de Ceilândia-DF, 2015.................52

Figura 20. Sala de Aula - acervo da autora. CEM 03 de Ceilândia-DF, 2015........................52

Figura 21. Formulário-Árvore - acervo da autora. Brasília-DF, 2015 ...................................57

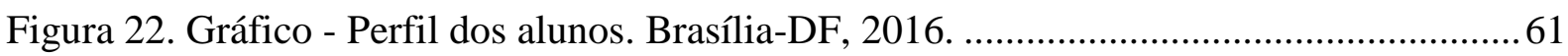

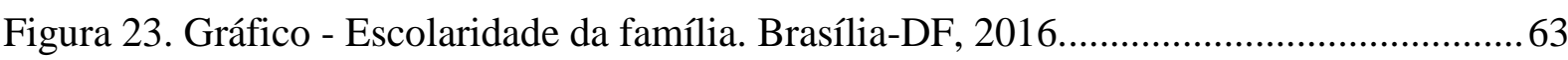

Figura 24. Gráfico - Formação Educacional e Profissional. Brasília-DF, 2016.......................66

Figura 25. Lugares de lembrar a infância - aluno P-Oito. CED 01 de Planaltina-DF, 2015....93

Figura 26. Lugares de lembrar a cidade e sua inserção - aluno P-Oito. CED 01 de Planaltina-

DF, 2015 .

Figura 27. Lugares de sonhar: perspectivas futuras - aluno P-Oito. CED 01 de Planaltina-DF, 2015.

Figura 28. Mensagem do WhatsApp - aluno P-Oito. CED 01 de Planaltina-DF, 2015.......... 98

Figura 29. Mensagem do WhatsApp - aluno P-Oito. CED 01 de Planaltina-DF, 2015...........98

Figura 30. Mensagem do WhatsApp - aluno P-Oito. CED 01 de Planaltina-DF, 2015.......... 99 
Figura 31. Mensagem do WhatsApp - aluno P-Oito. CED 01 de Planaltina-DF, 2015.

Figura 32. Lugares de lembrar a infância - aluno P-Sete. CED 01 de Planaltina-DF, 2015. . 100

Figura 33. Lugares de lembrar a cidade e sua inserção - aluno P-Sete. CED 01 de Planaltina DF, 2015.

Figura 34. Lugares de sonhar: perspectivas futuras - aluno P-Sete. CED 01 de Planaltina-DF, 2015 . 103

Figura 35. Mensagem do WhatsApp - aluno P-Sete. CED 01 de Planaltina-DF, 2015........ 104

Figura 36. Mensagem do WhatsApp - aluno P-Sete. CED 01 de Planaltina-DF, 2015 ......... 104

Figura 37. Mensagem do WhatsApp - aluno P-Sete. CED 01 de Planaltina-DF, 2015......... 105

Figura 38. Mensagem do WhatsApp - aluno P-Sete. CED 01 de Planaltina-DF, 2015 ........ 105

Figura 39. Mensagem do WhatsApp - aluno P-Sete. CED 01 de Planaltina-DF, 2015........ 105

Figura 40. Mensagem do WhatsApp - aluno P-Sete. CED 01 de Planaltina-DF, 2015......... 105

Figura 41. Mensagem do WhatsApp - aluno P-Sete. CED 01 de Planaltina-DF, 2015........ 106

Figura 42. Mensagem do WhatsApp - aluno P-Sete. CED 01 de Planaltina-DF, 2015........ 106

Figura 43. Mensagem do WhatsApp - aluno P-Sete. CED 01 de Planaltina-DF, 2015........ 106

Figura 44. Mensagem do WhatsApp - aluno P-Sete. CED 01 de Planaltina-DF, 2015 ......... 106

Figura 45. Lugares de lembrar a infância - aluno P-Dois. CED 01 de Planaltina-DF, 2015. 107

Figura 46. Lugares de lembrar a cidade e sua inserção - aluno P-Dois. CED 01 de Planaltina-

DF, 2015 .

Figura 47. Lugares de sonhar: perspectivas futuras - aluno P-Dois. CED 01 de Planaltina-DF, 2015 . 110

Figura 48. Mensagem do WhatsApp - aluno P-Dois. CED 01 de Planaltina-DF, 2015.

Figura 49. Mensagem do WhatsApp - aluno P-Dois. CED 01 de Planaltina-DF, 2015.

Figura 50. Lugares de lembrar a infância - aluno P-Três. CED 01 de Planaltina-DF, 2015..113

Figura 51. Lugares de lembrar a cidade e sua inserção - aluno P-Três. CED 01 de PlanaltinaDF, 2015. 114

Figura 52. Lugares de sonhar: perspectivas futuras - aluno P-Três. CED 01 de Planaltina-DF, 2015. 115

Figura 53. Mensagem do WhatsApp - aluno P-Três. CED 01 de Planaltina-DF, 2015. 116

Figura 54. Lugares de lembrar a infância - aluno P-Quatro. CED 01 de Planaltina-DF, 2015.

Figura 55. Lugares de lembrar a cidade e sua inserção - aluno P-Quatro. CED 01 de Planaltina-DF, 2015. 118 
Figura 56. Lugares de sonhar: perspectivas futuras - aluno P-Quatro. CED 01 de PlanaltinaDF, 2015 .

Figura 57. Mensagem do WhatsApp - aluno P-Quatro. CED 01 de Planaltina-DF, 2015..... 120

Figura 58. Mensagem do WhatsApp - aluno P-Quatro. CED 01 de Planaltina-DF, 2015.... 120

Figura 59. Mensagem do WhatsApp - aluno P-Quatro. CED 01 de Planaltina-DF, 2015.... 120

Figura 60. Lugares de lembrar a infância - aluno P-Cinco. CED 01 de Planaltina-DF, 2015.

Figura 61. Lugares de lembrar a cidade e sua inserção - aluno P-Cinco. CED 01 de Planaltina -DF, 2015.

Figura 62. Lugares de sonhar: perspectivas futuras - aluno P-Cinco. CED 01 de PlanaltinaDF, 2015. 124

Figura 63. Mensagem do WhatsApp - aluno P-Cinco. CED 01 de Planaltina-DF, 2015. .... 125

Figura 64. Mensagem do WhatsApp - aluno P-Cinco. CED 01 de Planaltina-DF, 2015. .... 125

Figura 65. Mensagem do WhatsApp - aluno P-Cinco. CED 01 de Planaltina-DF, 2015. .... 125

Figura 66. Mensagem do WhatsApp - aluno P-Cinco. CED 01 de Planaltina-DF, 2015. .... 125

Figura 67. Lugares de lembrar a infância - aluna P-Um. CED 01 de Planaltina-DF, 2015. .. 126

Figura 68. Lugares de lembrar a cidade e sua inserção - aluna P-Um. CED 01 de PlanaltinaDF, 2015.

Figura 69. Lugares de sonhar: perspectivas futuras - aluna P-Um. CED 01 de Planaltina-DF, 2015 . 131

Figura 70. Mensagem do WhatsApp - aluna P-Um. CED 01 de Planaltina-DF, 2015. 132

Figura 71. Mensagem do WhatsApp - aluna P-Um. CED 01 de Planaltina-DF, 2015......... 132

Figura 72. Mensagem do WhatsApp - aluna P-Um. CED 01 de Planaltina-DF, 2015.......... 132

Figura 73. Mensagem do WhatsApp - aluna P-Um. CED 01 de Planaltina-DF, 2015.......... 132

Figura 74. Mensagem do WhatsApp - aluna P-Um. CED 01 de Planaltina-DF, 2015.......... 133

Figura 75. Mensagem do WhatsApp - aluna P-Um. CED 01 de Planaltina-DF, 2015.......... 133

Figura 76. Mensagem do WhatsApp - aluna P-Um. CED 01 de Planaltina-DF, 2015......... 133

Figura 77. Mensagem do WhatsApp - aluna P-Um. CED 01 de Planaltina-DF, 2015......... 133

Figura 78. Lugares de lembrar a infância - aluna P-Seis. CED 01 de Planaltina-DF, 2015... 134

Figura 79. Lugares de lembrar a cidade e sua inserção - aluna P-Seis. CED 01 de PlanaltinaDF, 2015.

Figura 80. Lugares de sonhar: perspectivas futuras - aluna P-Seis. CED 01 de Planaltina-DF, 2015 . 138 
Figura 81. Mensagem do WhatsApp - aluna P-Seis. CED 01 de Planaltina-DF, 2015. 139

Figura 82. Mensagem do WhatsApp - aluna P-Seis. CED 01 de Planaltina-DF, 2015 139

Figura 83. Mensagem do WhatsApp - aluna P-Seis. CED 01 de Planaltina-DF, 2015......... 139

Figura 84. Mensagem do WhatsApp - aluna P-Seis. CED 01 de Planaltina-DF, 2015.......... 139

Figura 85. Mensagem do WhatsApp - aluna P-Seis. CED 01 de Planaltina-DF, 2015.......... 140

Figura 86. Mensagem do WhatsApp - aluna P-Seis. CED 01 de Planaltina-DF, 2015......... 140

Figura 87. Lugares de lembrar a infância - aluno C-Treze. CEM 03 de Ceilândia-DF, 2015.

Figura 88. Lugares de lembra a cidade - aluno C-Treze. CEM 03 de Ceilândia-DF, 2015...142 Figura 89. Lugares de sonhar: perspectivas futuras - aluno C-Treze. CEM 03 de CeilândiaDF, 2015. 143

Figura 90. Mensagem do WhatsApp - aluno C-Treze. CEM 03 de Ceilândia-DF, 2015....... 144 Figura 91. Mensagem do WhatsApp - aluno C-Treze. CEM 03 de Ceilândia-DF, 2015....... 144 Figura 92. Mensagem do WhatsApp - aluno C-Treze. CEM 03 de Ceilândia-DF, 2015....... 145 Figura 93. Mensagem do WhatsApp - aluno C-Treze. CEM 03 de Ceilândia-DF, 2015....... 145 Figura 94. Mensagem do WhatsApp - aluno C-Treze. CEM 03 de Ceilândia-DF, 2015....... 146 Figura 95. Mensagem do WhatsApp - aluno C-Treze. CEM 03 de Ceilândia-DF, 2015....... 146 Figura 96. Mensagem do WhatsApp - aluno C-Treze. CEM 03 de Ceilândia-DF, 2015....... 146 Figura 97. Mensagem do WhatsApp - aluno C-Treze. CEM 03 de Ceilândia-DF, 2015....... 146 Figura 98. Lugares de lembrar a infância - aluno C-Dez. CEM 03 de Ceilândia-DF, 2015.. 148 Figura 99. Lugares de lembrar a cidade e sua inserção - aluno C-Dez. CEM 03 de CeilândiaDF, 2015.

Figura 100. Lugares de sonhar: perspectivas futuras - aluno C-Dez. CEM 03 de Ceilândia-DF, 2015 . 151

Figura 101. Mensagem do WhatsApp - aluno C-Dez. CEM 03 de Ceilândia-DF, 2015....... 152 Figura 102. Mensagem do WhatsApp - aluno C-Dez. CEM 03 de Ceilândia-DF, 2015....... 152 Figura 103. Mensagem do WhatsApp - aluno C-Dez. CEM 03 de Ceilândia-DF, 2015....... 152 Figura 104. Mensagem do WhatsApp - aluno C-Dez. CEM 03 de Ceilândia-DF, 2015....... 152 Figura 105. Lugares de lembrar a infância - aluna C-Um. CEM 03 de Ceilândia-DF, 2015. 154 Figura 106. Lugares de lembrar a cidade e sua inserção - aluna C-Um. CEM 03 de CeilândiaDF, 2015.

Figura 107. Lugares de sonhar: perspectivas futuras - aluna C-Um. CEM 03 de Ceilândia-DF, 2015. 156 
Figura 108. Lugares de lembrar a infância - aluno C-Oito. CEM 03 de Ceilândia-DF, 2015.

Figura 109. Lugares de lembrar a cidade e sua inserção - aluno C-Oito. CEM 03 de CeilândiaDF, 2015. 158

Figura 110. Lugares de sonhar: perspectivas futuras - aluno C-Oito. CEM 03 de CeilândiaDF, 2015 . 159

Figura 111. Mensagem do WhatsApp - aluno C-Oito. CEM 03 de Ceilândia-DF, 2015. ..... 160

Figura 112. Mensagem do WhatsApp - aluno C-Oito. CEM 03 de Ceilândia-DF, 2015. ..... 160

Figura 113. Mensagem do WhatsApp - aluno C-Oito. CEM 03 de Ceilândia-DF, 2015. ..... 160

Figura 114. Mensagem do WhatsApp - aluno C-Oito. CEM 03 de Ceilândia-DF, 2015. ..... 160

Figura 115. Lugares de lembrar a infância - aluno C-Sete. CEM 03 de Ceilândia-DF, 2015.

Figura 116. Lugares de lembrar a cidade e sua inserção - aluno C-Sete. CEM 03 de CeilândiaDF, 2015 .

Figura 117. Lugares de sonhar: perspectivas futuras - aluno C-Sete. CEM 03 de Ceilândia-DF, 2015.

Figura 118. Lugares de lembrar a infância - aluno C-Nove. CEM 03 de Ceilândia-DF, 2015.

Figura 119. Lugares de lembrar a cidade e sua inserção - aluno C-Nove. CEM 03 de Ceilândia-DF, 2015. 166

Figura 120. Lugares de sonhar: perspectivas futuras - aluno C-Nove. CEM 03 de CeilândiaDF, 2015.

Figura 121. Mensagem do WhatsApp - aluno C-Nove. CEM 03 de Ceilândia-DF, 2015..... 168 Figura 122. Lugares de lembrar a infância - aluna C-Três. CEM 03 de Ceilândia-DF, 2015.

Figura 123. Lugares de lembrar a cidade e sua inserção - aluna C-Três. CEM 03 de CeilândiaDF, 2015. 170

Figura 124. Lugares de sonhar: perspectivas futuras - aluna C-Três. CEM 03 de Ceilândia-DF, 2015.

Figura 125. Lugares de lembrar a infância - aluna C-Doze. CEM 03 de Ceilândia-DF, 2015.

Figura 126. Lugares de lembrar a cidade e sua inserção - aluna C-Doze. CEM 03 de Ceilândia-DF, 2015. 173 
Figura 127. Lugares de sonhar: perspectivas futuras - aluna C-Doze. CEM 03 de CeilândiaDF, 2015 .

Figura 128. Lugares de lembrar a infância - aluno C-Cinco. CEM 03 de Ceilândia-DF, 2015.

Figura 129. Lugares de lembrar a cidade e sua inserção - aluno C-Cinco. CEM 03 de Ceilândia-DF, 2015. 176

Figura 130. Lugares de sonha: perspectivas futuras - aluno C-Cinco. CEM 03 de CeilândiaDF, 2015 .

Figura 131. Lugares de lembrar a infância - aluno C-Seis. CEM 03 de Ceilândia-DF, 2015.

Figura 132. Lugares de lembrar a cidade e sua inserção - aluno C-Seis. CEM 03 de CeilândiaDF, 2015. 178

Figura 133. Lugares de sonhar: perspectivas futuras - aluno C-Seis. CEM 03 de Ceilândia-DF, 2015 . 179

Figura 134. Mensagem do WhatsApp - aluno C-Seis. CEM 03 de Ceilândia-DF, 2015....... 180

Figura 135. Mensagem do WhatsApp - aluno C-Seis. CEM 03 de Ceilândia-DF, 2015....... 180

Figura 136. Mensagem do WhatsApp - aluno C-Seis. CEM 03 de Ceilândia-DF, 2015....... 180

Figura 137. Lugares de lembrar a infância - aluno C-Quatro. CEM 03 de Ceilândia-DF, 2015.

Figura 138. Lugares de lembrar a cidade e sua inserção - aluno C-Quatro. CEM 03 de Ceilândia-DF, 2015.

Figura 139. Lugares de sonhar: perspectivas futuras - aluno C-Quatro. CEM 03 de CeilândiaDF, 2015

Figura 140. Lugares de lembrar a infância - aluna C-Onze. CEM 03 de Ceilândia-DF, 2015.

Figura 141. Lugares de lembrar a cidade e sua inserção - aluna C-Onze. CEM 03 de Ceilândia-DF, 2015.

Figura 142. Lugares de sonhar: perspectivas futuras - aluna C-Onze. CEM 03 de CeilândiaDF, 2015.

Figura 143. Lugares de lembrar a infância - aluno C-Dois. CEM 03 de Ceilândia-DF, 2015.

Figura 144. Lugares de lembrar a cidade e sua inserção - aluno C-Dois. CEM 03 de CeilândiaDF, 2015 . 188 
Figura 145. Lugares de lembrar a cidade e sua inserção - aluno C-Dois. CEM 03 de CeilândiaDF, 2015 . 189

Figura 146. Lugares de sonhar: perspectivas futuras - aluno C-Dois. CEM 03 de CeilândiaDF, 2015 . 


\section{LISTA DE ABREVIATURAS}

CED Centro Educacional

CEI Companhia de Erradicação de Invasões

CEM Centro de Ensino Médio

CRE Coordenação Regional de Ensino

CODEPLAN Companhia de Planejamento do Distrito Federal

CONFAEB Congresso Nacional da Federação de Arte Educadores do Brasil

EAPE Escola de Aperfeiçoamentos dos Profissionais de Educação

EJA Educação de Jovens e Adultos

DNOCS Departamento Nacional de Obras Contra a Seca do Nordeste

GDF Governo do Distrito Federal

IAPI Instituto de Aposentadoria e Pensões dos Industriários

IBGE Instituto Brasileiro de Geografia e Estatística

MEB Movimento de Educação de Base

MOBRAL Movimento Brasileiro de Alfabetização

NOVACAP Companhia de Urbanização da Nova Capital

ONU Organizações das Nações Unidas

PNAD Pesquisa Nacional por Amostra de Domicílios

QNQ Quadra Norte Q

QNR Quadra Norte R

RA VI Região Administrativa de Planaltina

RA IX Região Administrativa de Ceilândia

SEE-DF Secretaria de Estado de Educação do Distrito Federal

UnB Universidade de Brasília

UNESCO Organização das Nações Unidas para a Educação, a Ciência e a Cultura

UNICEF Fundo das Nações Unidas para a Infância 


\section{INTRODUÇÃO}

Era o ano de 1956 quando foi publicado o Edital para o Concurso do Plano Piloto da Nova Capital do Brasil, por esse Edital o prêmio para o autor do projeto vencedor seria um milhão de cruzeiros. Observa-se que pelo edital a cidade deveria ser pensada como centro político e administrativo do país, assim, sua função governamental deveria ser priorizada nos planos propostos, como pode ser observado em nota publicada em 1957, pela Companhia de Urbanização da Nova Capital - NOVACAP, por ocasião da divulgação do concurso:

(...) A capital, cidade funcional, deverá além disso, ter expressão arquitetural própria. Sua principal característica é a função governamental. Em torno dela se agrupam todas as outras funções e para ela tudo converge.

As unidades de habitação, os locais de trabalho, os centros de comércio e de descanso se integram em todas as cidades de uma maneira racional entre eles mesmos. Numa capital, tais elementos devem orientar-se, além disso, no sentido próprio do destino da cidade: a função governamental (NOVACAP, 1957, p. 06).

Um projeto de cidade racionalmente elaborada e definida de forma que seus espaços, autossuficientes, conseguissem criar uma imagem de cidade ordenada, limpa, que respondesse aos padrões de modernidade e urbanização que se instituíam como modelo a ser seguido.

Essa proposta levou James Holston (1993) a afirmar que o urbanismo no Brasil sofreu uma forte e significativa influência do urbanismo progressista francês que tinha como metas a racionalidade, a modernidade e a eficácia, proposta que considera apenas o espaço físico e desconsidera as questões sociais. Assim, as características desse progressivo francês no Brasil apresentavam-se na medida em que o fator urbano era definido como fenômeno unicamente físico e não considerava a cidade como processo social.

O discurso predominante na época era de que o traçado do Urbanista Lúcio Costa aliado às propostas arquitetônicas de Oscar Niemeyer resultaria em uma cidade, aparentemente fria, enigmática e silenciosa nas suas linhas horizontais, modelada por uma concepção arquitetônica atrevida e inquietante, mas na realidade, uma capital acolhedora e humana, com seus problemas resolvidos. Suas características funcionais representam uma grande revolução urbanística do século XX, ideia defendida por Orico (1959).

Inaugurada em 21 de abril de 1960, a cidade já apresentava alguns problemas que dificultavam a vida dos moradores como no setor de serviços: telefonia e mobilidade urbana, desemprego, habitação, violência e o surgimento de favelas no perímetro urbano do Plano Piloto. 
Nesse contexto surge a política de erradicação de favelas/invasões empreendida pelo Governo do Distrito Federal - GDF, com o objetivo de criar as cidades satélites para abrigar essa população, demonstrando que por melhor estruturado que seja o projeto urbanístico, ele não conseguiria dar conta da pluralidade de personagens, trajetórias, escolhas de seus habitantes e nos direcionamentos que seu plano assume no momento de ser posto em prática. Assim, o projeto da Nova Capital que propunha o uso racional do espaço e a garantia de uma convivência harmônica, quando posto em prática, a experiência traçou caminhos outros, impondo outros limites e outros desenhos.

Para Ribeiro (1982) em sua arqueologia de Brasília, o surgimento das cidades satélites destinava-se a resolver o problema de habitação na capital, lembrando a criação de Taguatinga, em 1958, para abrigar cerca de 5.000 flagelados da seca do Nordeste. Para o autor, rompia-se assim, a utopia de Lúcio Costa de edificar uma cidade em que as diferenças de classes não seriam determinantes de uma política de segregação. As cidades satélites estabeleceram-se para manter o Plano Piloto imaculado da presença dos trabalhadores da construção civil. Em sua configuração urbana, a força do trabalho atuante na construção civil, aqueles que se encontravam na informalidade eram mantidos na periferia, enquanto os trabalhadores formais que vieram transferidos com o objetivo de trabalhar na administração federal habitavam o Plano Piloto.

De todos os problemas já existentes em Brasília, o que apresentava maior dimensão era o surgimento das favelas que "enfeia o Plano Piloto e contrasta com a sua exuberância arquitônica" (Paviani, 1991, p. 81).

Como podemos descrever na atualidade as contradições existentes no Distrito Federal? Qual a narrativa visual que alguns alunos da Educação de Jovens e Adultos - EJA têm da cidade?

\section{Trajetória de vida: Nova capital em tempo de construção}

A história de Brasília se entrelaça com a minha história de vida, bem como de outras pessoas que chegaram à cidade na década de 1960. Avivar essas lembranças tecidas a frio e poeira faz parte do presente estudo que tem como objetivo da pesquisa apreender as narrativas visuais produzidas pelos alunos da Educação de Jovens e Adultos sobre a cidade que vivem. Para a sua realização optou-se por duas Regiões Administrativas do Distrito Federal: Planaltina e Ceilândia. A escolha dessas regiões justifica-se por ser Planaltina uma 
cidade pré-existente à inauguração de Brasília, e a cidade de Ceilândia criada após a existência da capital.

No contexto de organização da administração pública da Nova Capital, que no ano de 1965, minha família foi compulsoriamente transferida do Nordeste. Meu pai era funcionário público lotado no extinto Ministério do Interior, no Departamento Nacional de Obras Contra as Secas do Nordeste - DNOCS, atuava no Ceará e prontamente aceitou o convite para compor o quadro de funcionários públicos da Nova Capital.

Minha mãe, filha de agricultores de café do interior do Ceará, tinha sido registrada sem o sobrenome dos pais, sendo denominada apenas de Maria Margarida. Conheceu meu pai em uma das festas religiosas que costumam acontecer nas cidades interioranas do Nordeste, como Mulungu, cidade de minha mãe e Baturité, cidade do meu pai.

Tanto quanto, meu pai quanto a minha mãe eram oriundos de lares católicos. Era costume na época, as famílias enviarem filhos e filhas para os conventos e seminários. Minha família não fugiu à regra, da família da minha mãe: três tias freiras e um tio padre e do lado do meu pai, duas tias freiras.

Meus pais se casaram no ano de 1951, minha mãe já tinha na época vinte e sete anos. Meu pai costumava brincar que ele foi o herói que a salvou do convento. Após o casamento minha mãe incorporou o sobrenome do marido, e passou a assinar Maria Margarida Martins como consta em seus documentos, entretanto por um resgate de sua subjetividade, minha mãe nunca deixou de acrescentar o sobrenome de seu pai ao se identificar. Esta é a minha família, composta inicialmente por oito pessoas (pai, mãe e seis filhos), sendo três mulheres e três homens.

Por ordem de data de nascimento, sou a terceira mulher e a quinta filha, e o único membro da família que nasceu na cidade de Floriano/Piauí. Aqui chegamos à Nova Capital, dois irmãos adolescentes e dois pré-adolescentes, eu com três anos e o mais novo recémnascido. Fomos habitar em uma das asas do Plano Piloto, a Asa Norte. Fotografia do álbum de família de 1968, figura 1, a seguir. 


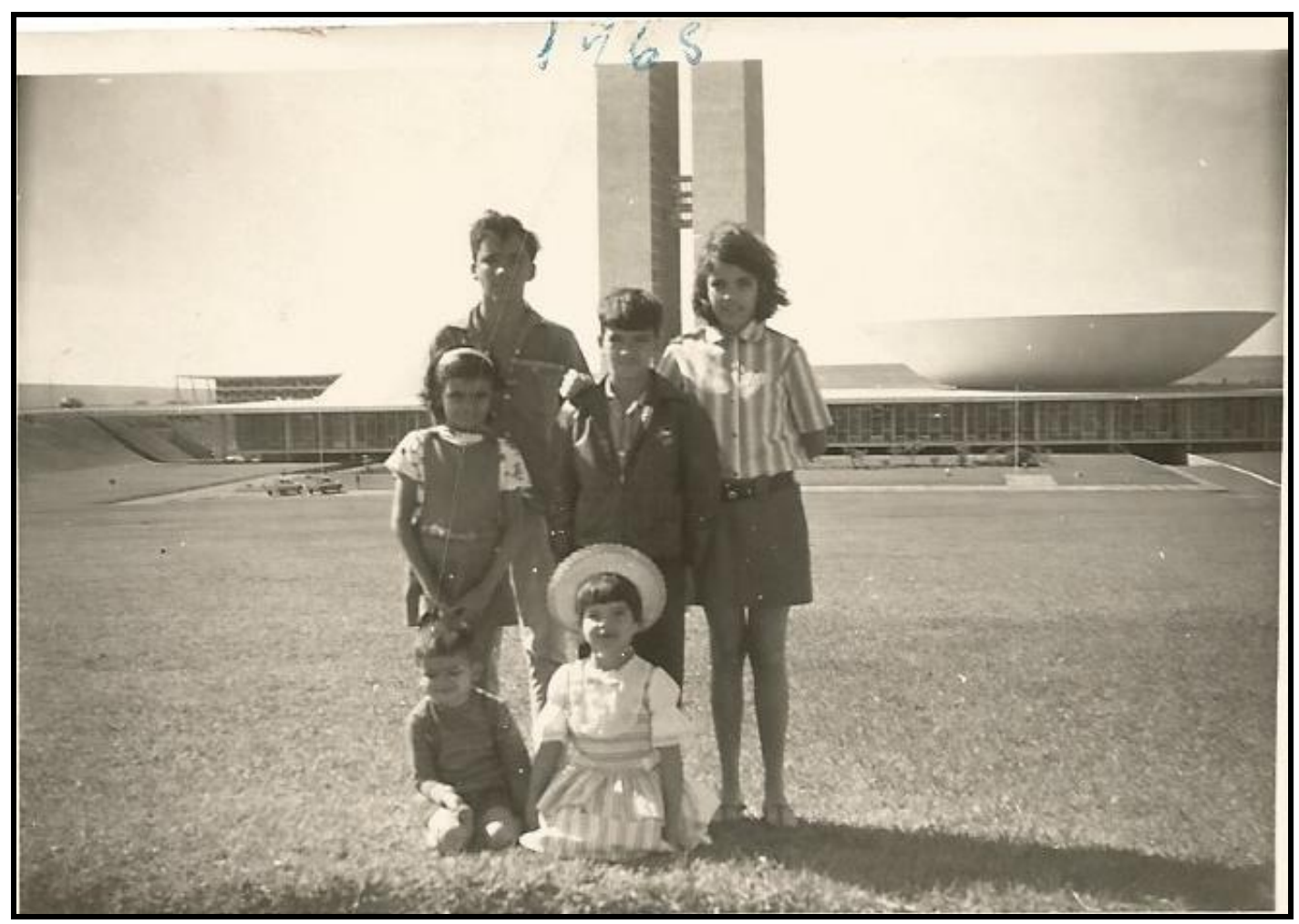

Figura 1. Irmãos, 1968 - acervo da autora. Brasília-DF, 2015.

A temperatura de Brasília no ano de 1965 era muito fria. O vento frio e a poeira erram acirrados pela profusão de obras. O clima seco favorecia os constantes sangramentos do nariz e rachaduras nos cotovelos, joelhos, pés e mãos das crianças, como bem lembra minha mãe.

A cidade oferecia poucos espaços para as crianças, como parque de diversão com balanços e escorregadores. Apenas no ano de 1971, foi inaugurado o Parque Iolanda Costa e Silva, hoje Parque Ana Lídia. Por isso, tivemos que desenvolver a criatividade para inventar nossas brincadeiras como os recursos disponíveis, como restos de materiais das obras. As manilhas eram as minhas favoritas, por elas, eu e meus irmãos corríamos e gritávamos, ouvindo o som ecoar por um maior período de tempo, subir na cagaiteira ${ }^{1}$, colher seus frutos e comê-los sentados embaixo da árvore. Costumávamos brincar de pique esconde entre paredes de tijolos soltos. No período de chuvas, o barro atolava até nossos joelhos, mas também fornecia matéria para modelar brinquedos: bolinhas, pratos e xícaras.

Era uma criança que vivia constantemente sem unha, arranhada, machucada, descabelada e emburrada. O meu apreço pelas brincadeiras de rua era muito criticado por minhas irmãs mais velhas que diziam que eu deveria ter nascido homem, visto que os homens

\footnotetext{
${ }^{1}$ Cagaiteira árvore típica do cerrado que produz um fruto pequeno com casca amarela esverdeada, polpa suculenta e ácida denominada cagaita.
} 
da minha família nasceram antes das mulheres formando casais e eu nasci antes do meu irmão mais novo, portanto a ordem foi invertida; além disso, fui a única nascida no Piauí. Esses fatos acirravam as críticas: equívoco de gênero e de naturalidade.

Minha primeira escola em Brasília era de madeira e atendia as crianças da Asa Norte. Era improvisada numa igreja e se chamava Escola Classe Paulo IV.

Em relação à vida política do país, senti a tensão dos anos da ditadura, já que meu pai procurava manter meus irmãos mais velhos próximos de casa, o que restringia as atividades de um adolescente. Enquanto isso, eu continuava gritando dentro das manilhas.

Fruto de relações parentais patriarcais, meu pai era o provedor da casa. Com a sua morte em 1974, nove anos depois da nossa transferência para Brasília, o nosso cotidiano mudou radicalmente. Os irmãos mais velhos tiveram que trabalhar e minha mãe que era dona de casa, tornou-se costureira. Os irmãos mais jovens, como eu, além de estudar ajudavam nos afazeres domésticos. Os primeiros anos foram difíceis, mas depois as coisas entraram nos eixos.

Logo que conclui o Ensino Fundamental e o Ensino Médio, na época $1^{o}$ e $2^{o}$ Graus comecei a trabalhar para reforçar o orçamento doméstico. Antes de ingressar no Ensino Superior casei e nasceram seguidamente dois lindos filhos, Pedro e Mariana. Senti na pele o que é criar filhos, tomar conta de casa e estudar ao mesmo tempo. Mesmo assim, consegui terminar minha graduação em Pedagogia.

Atualmente, minha família é constituída de minha mãe, com noventa e dois anos, cinco filhos, doze netos e seis bisnetos. Muitos se foram e outros chegaram, e eu continuo com a mesma sensação de que a cidade é meu universo. Sigo trabalhando e estudando feliz da vida, como criança gritando nas manilhas e esperando reverberar o som dos meus gritos.

Como eu e minha família, muitos chegaram à Brasília e suas histórias e experiências foram diferenciadas. Muitos abandonaram a escola por vários motivos e atualmente buscam na Educação de Jovens e Adultos retomarem requisitos para o exercício da cidadania.

Foi a riqueza das experiências vividas por mim e por outras pessoas que despertaram a curiosidade de desenvolver um estudo sobre as diversas formas de ver e narrar o espaço urbano. Como parte da minha experiência profissional é com alunos jovens e adultos recaiu sobre eles a direção da pesquisa, procurando apreender as suas narrativas visuais perpassando a infância, o momento atual e as perspectivas futuras. 


\section{Trajetórias tecidas e escolhas da pesquisa}

No filme dirigido por Tim Burton e baseado no clássico do livro Alice no País das Maravilhas $^{2}$ apresenta o seguinte diálogo entre Alice e o Gato de Cheshire ${ }^{3}$ :

Alice: O senhor poderia me dizer, por favor, qual o caminho que devo tomar para sair daqui?

- Isso depende muito para onde você quer ir, respondeu o Gato.

- Não me importo muito para onde, retrucou Alice.

- Então não importa o caminho que você escolha, disse o gato.

A partir desse trecho do filme pode ser feita uma alusão ao método seguido pelo pesquisador na sua pesquisa. Conforme sentido etimológico a palavra método vem do grego, methodos, composta de meta (através de, por meio) e de hodos (via, caminho). O que quer dizer que em uma pesquisa deve-se ordenar o trajeto através do qual se possa alcançar os objetivos propostos.

$\mathrm{Na}$ pesquisa em questão o passo inicial foi a escolha e público-alvo: o aluno da Educação de Jovens e Adultos - EJA. Esta modalidade de educação incorpora os alunos que foram afastados da escola ou que retardaram o início de sua trajetória escolar. Pessoas que já formaram sua visão de mundo pelas experiências vividas e que têm suas crenças e valores já constituídos. Esse público é diverso, em seus traços de vida, origem, idade, vivências profissionais, históricos escolares, ritmos e estruturas de aprendizagem diferenciadas.

Para a delimitação do tema da pesquisa teve como perspectiva especifica a apreensão das visualidades cotidianas dos alunos sobre a cidade em que habitam.

Dessa forma, o passo seguinte foi a definição da estratégia de coleta de informações, analise e forma de tratamento do problema a ser estudado. Ficando como objetivos da pesquisa:

- Apreender a narrativa visual dos alunos de EJA na sua relação com as visualidades no espaço urbano;

- Refletir como eles veem a cidade onde vivem;

- Compreender se as visualidades cotidianas afetam a leitura do mundo e como essa leitura é influenciada pela experiência de vida do aluno.

\footnotetext{
${ }^{2}$ Filme estadunidense-britânico de 2010, dirigido por Tim Burton e baseado no livro clássico: Alice no País das Maravilhas, escrito por Lewis Carroll. https://www.google.com.br

${ }^{3}$ Site: https://pensador.uol.com.br/autor/alice_no_pais_das_maravilhas lewis_carroll//
} 
Esses objetivos foram traçados procurando determinar o propósito da pesquisa em relação ao tema e aos resultados alcançados.

O problema da pesquisa foi gerado partindo-se do pressuposto sociocultural de que o ser humano é construtor e construído pelas interações sociais e culturais: Como os alunos da Educação de Jovens e Adultos interagem com as visualidades cotidianas? Como estas visualidades influenciam a leitura dos espaços que vivem?

Em seguida, foi a vez de pensar sob qual base teórica da pesquisa, a escolha foi a cultura visual, um campo de estudo pluridisciplinar que associa conceitos sociais e culturais de representação da realidade. A intenção foi instaurar interpretações e reflexões acerca das imagens do cotidiano e como elas interferem na compreensão do espaço habitado pelos alunos.

Assim, a fundamentação da pesquisa optou-se por discorrer sobre as teorias da psicologia histórico-cultural dos autores que contemplam os ensinamentos acerca do conhecimento, com Lev Vigostky e Paulo Freire, que acreditam que o processo de construção do conhecimento ocorre por meio da interação do sujeito historicamente situado com ambiente sociocultural onde vive.

Para falar sobre a Educação de Jovens e Adultos respaldou-se em trabalhos de autores como Celso Rui Beisiegel, Vera Masagão e Sérgio Hadadd, que discutem a educação de jovens e adultos como um campo de prática e reflexão que transborda os limites da escolarização.

Acerca da concepção de narrativa o diálogo foi travado com Walter Benjamim e o seu entendimento da narrativa como expressão da experiência. Além de Benjamim, foi de fundamental importância, o trabalho de Clandinin e Connelly que propõem uma abordagem de pesquisa qualitativa para a compreensão e interpretação das dimensões pessoais e humanas além dos métodos tradicionais de pesquisa.

Os conceitos que fundamentam a cultura visual são aqueles produzidos por Fernando Hernández, Raimundo Martins e Irene Tourinho, dentre outros.

Para a coleta que subsidiou a geração de dados, utilizou-se alguns instrumentos de pesquisa, como o questionário, composto de trinta e sete questões fechadas, para identificar o perfil do aluno da pesquisa, o portfólio para a organização das narrativas individuais dos alunos e a dinâmica da árvore que resultou no formulário com indicações dos sonhos e perspectivas futuras dos pesquisados. 
Por meio desses instrumentos foi possível compor a narrativa visual dos alunos, constituída do material impresso ancorada na imagem e no texto, como uma linguagem que conta histórias do contexto sociocultural e apresenta a maneira como os alunos visualizam o cotidiano e interpretam as imagens que circulam pelos diversos meios de tecnologias de informação e comunicação. A pesquisa foi desenvolvida em sala de aula, considerada como espaço privilegiado de vivências, interações e mediações para a produção de narrativas visuais respaldada na cultura visual.

A escolha do tema de pesquisa ganhou ênfase com a percepção da escassez de pesquisas destinadas a narrativa visual dos alunos da Educação de Jovens e Adultos na perspectiva da cultura visual. Bem como, na incipiente abordagem dos estudos da cultura visual, no atual currículo da Secretaria de Estado de Educação do Distrito Federal, no componente curricular de Arte destinado à EJA.

Tendo em vista a relevância do tema, espera-se que esta pesquisa fomente elementos que possam contribuir para o ensino e aprendizagem da Arte, como campo de organização dos saberes educacionais, artísticos e culturais, em contraposição a uma educação intelectualista que prevalece os estudos de obra de arte, desconsiderando o cotidiano saturado de imagens que produzem mensagens e informações visuais.

A escrita do texto tem como ponto de partida a construção da Nova Capital, em seguida se deteve no surgimento das Regiões Administrativas, para assim, justificar os lugares da pesquisa configurada como espaço urbano que os alunos de EJA vivem, e onde foi realizada as apreensões das narrativas visuais produzidas pelos alunos das duas instituições educacionais da rede pública de ensino do DF: uma em Planaltina e outra em Ceilândia, conforme mapa do Distrito Federal, figura 2.

Dentre as diversas Regiões Administrativas do Distrito Federal, as escolhas foram por Planaltina por ser uma cidade pré-existente à inauguração de Brasília, desde o ano de 1859, e Ceilândia, cidade criada após a inauguração de Brasília, nos anos de 1971 e 1972. Assim, procurou-se contrapor duas realidades: uma já existente e outra que passa a existir após a inauguração de Brasília. 


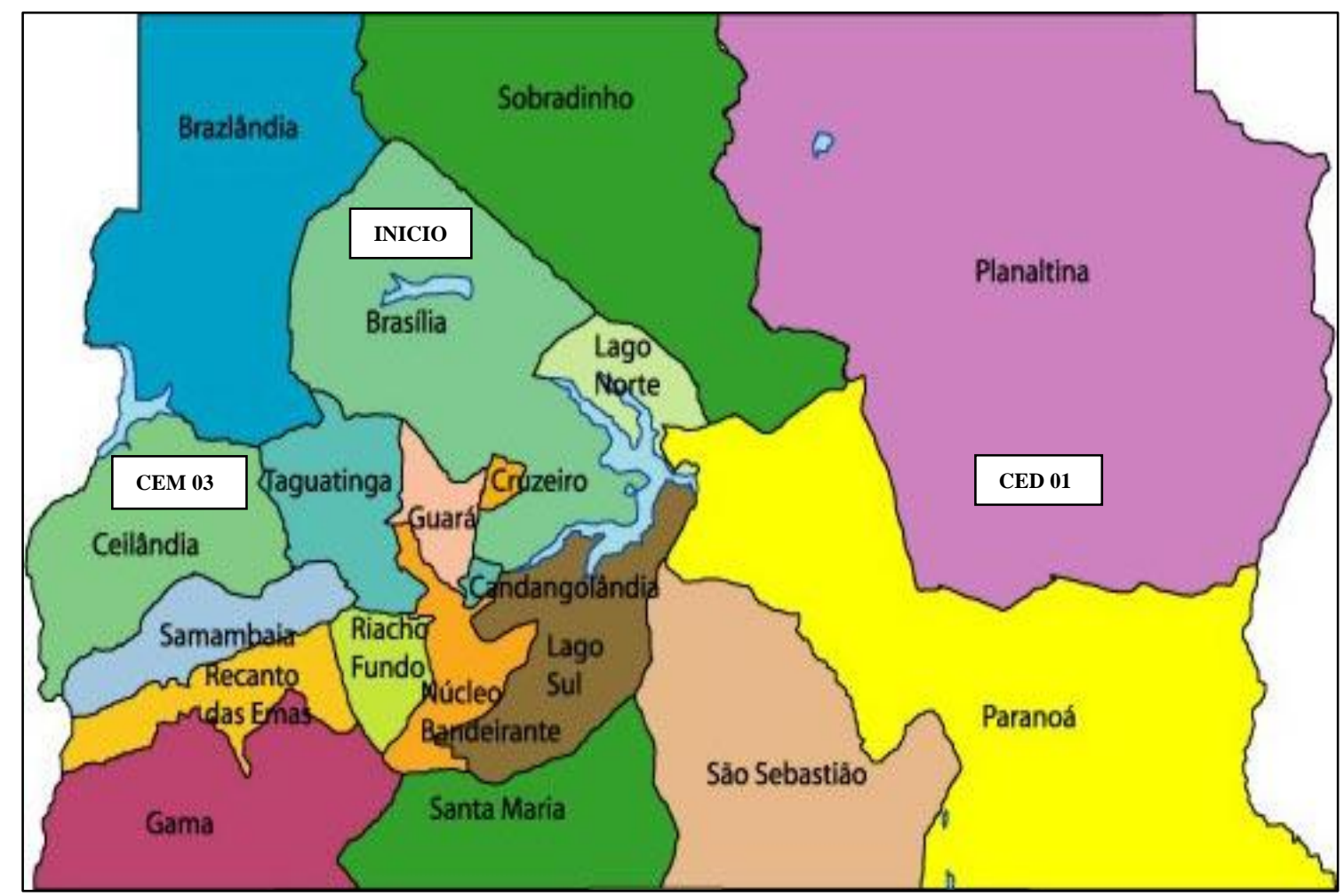

Figura 2. Mapa do Distrito Federal ${ }^{4}$. Brasília-DF, 2016.

A seleção das duas instituições educacionais, uma em cada Região Administrativa, teve como critérios: a oferta da Primeira Etapa do Terceiro Segmento de Educação de Jovens e Adultos; a localizada no espaço urbano e a antiguidade. O Centro Educacional 01 de Planaltina é a escola mais antiga de Planaltina, criada em 1961 e o Centro de Ensino Médio 03 de Ceilândia, foi construído em 1971, juntamente com a cidade.

A pesquisa foi organizada da seguinte forma: uma introdução, seis capítulos e as considerações finais.

No capítulo 1 , Os lugares da pesquisa, discorreu-se sobre a construção da Nova Capital, destacando o movimento migratório dos trabalhadores da administração pública, da construção civil e de pessoas que vieram em busca de melhores condições de vida. Em seguida, foi realizado um pequeno histórico das Regiões Administrativas da pesquisa: Planaltina e Ceilândia e suas respectivas escolas da modalidade de Educação de Jovens e Adultos.

O segundo capítulo, Os alunos da pesquisa, foi realizado um resumo da EJA no Brasil, desde as propostas de erradicação do analfabetismo dos anos 1960 e a mudança no perfil do aluno de EJA na atualidade. E, os percursos da pesquisa para o desenvolvimento da prática pedagógica nas escolas e apreensões das narrativas visuais dos alunos da Educação de 
Jovens e Adultos sobre os espaços urbanos das Regiões Administrativas de Planaltina e Ceilândia.

No capítulo 3 Metodologia da pesquisa, detalhou-se sobre a metodologia qualitativa empregada na pesquisa, bem como os instrumentos utilizados na geração de informações, tais como: questionário, portfólio e a dinâmica da árvore, com seu formulário. O questionário foi utilizado para identificação dos alunos jovens e adultos, estruturado com questões para assimilar aspectos socioeconômicos dos alunos, a escolaridade de sua família e a formação educacional e profissional dos alunos. O portfólio e o formulário-árvore constituíram-se as narrativas visuais produzidas, individualmente, pelos alunos.

No quarto capítulo, Referencial teórico da pesquisa abordou-se sobre as contribuições teóricas oriundas da psicologia histórico-cultural e as aproximações epistemológicas de Freire e Vigotsky. Além dos referenciais acerca da experiência e narrativa, narrativa visual e da cultura visual, observando a ausência do enfoque da cultura visual no Currículo em Movimento da Secretaria de Estado da Educação do Distrito Federal, destinado para essa modalidade de educação.

No capítulo 5, Narrativas visuais dos alunos, apresentou-se o portfólio individual dos alunos das duas escolas, expondo as leituras das narrativas visuais dos alunos, atravessado por leituras, diálogos e reflexões de experiências vividas refletindo sobre o olhar no que os alunos olham, como se olham e como reproduziram os espaços urbanos em que vivem.

No sexto capítulo, Costurando as narrativas visuais dos alunos refletiu-se sobre as narrativas visuais produzidas pelos alunos das escolas CED 01 de Planaltina e CEM 03 de Ceilândia da modalidade de Educação de Jovens e Adultos, sobre os espaços urbanos em que habitam. Narradas nas diferentes experiências de vidas, nos espaços de brincadeiras, nas diferenças espaciais e de convivência e na desigualdade social.

Nas Considerações finais, momento em que foram expostos o desenvolvimento e os resultados da pesquisa sobre as narrativas visuais dos alunos da Educação de Jovens e Adultos. 


\section{OS LUGARES DA PESQUISA}

Ainda é comum o entendimento do espaço como vazio, vácuo, estático e sem articulação. Este parece ser o entendimento durante a ocupação do espaço do Distrito Federal: uma ação de planejamento estatal. Entretanto, a migração massiva em direção à construção da capital provocava uma ocupação não planejada do território e demonstrava a necessidade de ampliação de áreas para acomodar os novos trabalhadores da construção civil, ou seja, a população de trabalhadores não absorvida nos acampamentos das construtoras. Com essa lógica de espaço foi criada a cidade-satélite de Taguatinga, em 1958, o primeiro loteamento fora do perímetro planejado.

Segundo Oliveira (2008), após a decisão de se criar a primeira cidade-satélite, a NOVACAP transferiu, não só parte dos trabalhadores da construção, como também as "invasões" que vinham se formando para Taguatinga e, no final do ano de 1958, o loteamento previsto para 15 mil habitantes já abrigava 10 mil, tornando-se ponto de chegada dos "novos bandeirantes", que vinham para a nova fronteira.

Dados da Companhia de Planejamento do Distrito Federal - CODEPLAN e do Instituto Brasileiros de Geografia e Estatística - IBGE indicam que em 1957, a população na Nova Capital era de 12.283 habitantes, representando uma densidade humana de 2,1 habitantes por quilômetro quadrado. Em três anos o território que define o Distrito Federal, atinge um contingente populacional de 140.164, espalhado no Plano Piloto e em oito cidadessatélites: Taguatinga, Gama, Sobradinho, Núcleo Bandeirante, Cruzeiro, Candangolândia, Planaltina e Brazlândia. Consequentemente, a maciça população que vinha de outros estados em direção à construção da capital provocou uma ocupação não planejada do território.

É possível visualizar a evolução migratória no Distrito Federal, nos dados da CODEPLAN, sobre a população no período de 1960-2010, figura 3. Os dados são referentes ao fluxo migratório e o nascimento de pessoas no Distrito Federal, entre os anos de 19602010, indicando que a migração constituída, principalmente pelo Nordeste, seguida pela região Sudeste, tende a diminuir, sendo superada pelo número de nascimentos no território do Distrito Federal. 


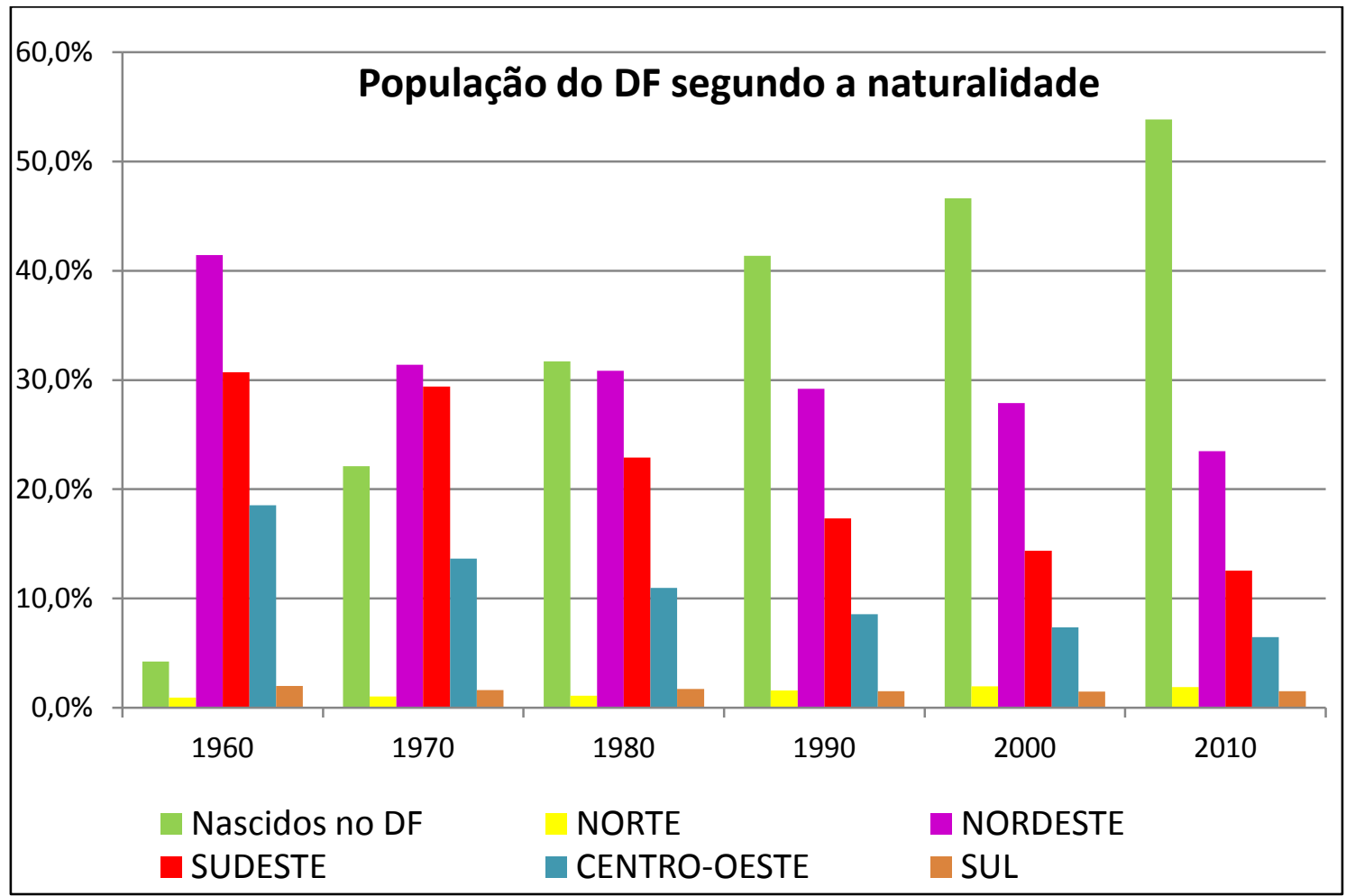

Figura 3. Gráfico - População do $\mathrm{DF}^{5}$ segundo a naturalidade. Brasília-DF, 2016.

As transformações ocorridas no período da ocupação do Distrito Federal estabeleceram novas dinâmicas fazendo-se necessário rever o conceito de espaço, não como vazio, mas sim como um território em movimento contínuo. Essa é a visão do geógrafo Milton Santos que pensou o espaço a partir de diferentes significados historicamente definidos, e compreendido como um conjunto de formas representativas de relações sociais do passado e do presente, e por uma estrutura representada por relações que estão acontecendo e se manifestam por meio de processos e funções. "O espaço é um verdadeiro campo de forças cuja formação é desigual. Eis a razão pelas quais a evolução espacial não se apresenta de igual forma em todos os lugares" (Santos, 1978, p.122).

Esta definição de espaço subsidiou o nosso entendimento do espaço no Distrito Federal, por suas características e por seu funcionamento, pelo que ele oferece a alguns e recusa a outros, pela seleção de localização realizada entre as atividades e possibilidades dos homens, enfim, o espaço como resultado de uma práxis coletiva que reproduz as relações sociais e culturais.

\footnotetext{
${ }^{5}$ Fonte: CODEPLAN, Evolução dos Movimentos Migratórios para o Distrito Federal 1959-2010. Demografia em Foco $\mathrm{n}^{\circ} 7$. Brasília, 2013.
} 


\subsection{A Cidade de Planaltina}

Diferentemente do que pensam alguns, a região destinada à construção da Nova Capital não era um cerrado em meio ao absoluto nada. Existiam povoados e cidades anteriores, como por exemplo, Planaltina ${ }^{6}$.

Planaltina é um núcleo existente desde o século XIX (1859), juntamente com Brazlândia (1934), que se constituíram em localidades que foram anexadas ao território do Distrito Federal. Luziânia (1746), Formosa (1843) e Planaltina de Goiás (1790) são municípios goianos fronteiriços que perderam área para a formação do Distrito Federal.

A cidade de Planaltina está localizada a Nordeste do Distrito Federal. Segundo Bertran (1994), Planaltina é parte da Estrada Real ${ }^{7}$ que liga o litoral atlântico às margens do Guaporé, na fronteira boliviana. Essa rota incidiu sobre o trecho do Planalto Central onde se encontram os tributários dos rios: Maranhão (afluente do Tocantins), Preto (afluente São Francisco) e os rios São Bartolomeu e Descoberto (afluente do Paraná).

Segundo Joffily (1977), a primeira referência da ocupação de Planaltina encontra-se em Bartolomeu Bueno da Silva Filho, quando saiu de São Paulo em 1772, para o interior de Goiás, a fim de explorar as minas de ouro e de esmeralda. Os caminhos abertos foram utilizados para o escoamento de metais e para a arrecadação de dízimos territoriais para a Coroa e deram origem a diversas vilas e arraias.

O seu povoamento foi marcado por duas atividades: a mineração e a agropecuária. A mineração iniciou o processo de ocupação na busca de metais preciosos que atraiu para as zonas mineradoras uma vasta população livre e escrava, possibilitando intenso comércio entre as regiões da Colônia. Mas, foi a agricultura e a pecuária as responsáveis pela fixação do colonizador.

\footnotetext{
${ }^{6}$ Planaltina (RA VI), maior Região Administrativa do DF em área territorial, equivalente a $1.534,69 \mathrm{Km}^{2}$, sendo que a maior parte do território é composta por chácaras e sitos, sendo considerara área rural. Cálculo efetuado pela Companhia do Desenvolvimento do Planalto Central, tomando como referência os memoriais descritivos dos limites das Regiões Administrativas, lançadas sobre a base cartográfica 1:10.000. Incluem-se na Área Rural, os Parques Nacionais, Reservas Florestais, Áreas de Proteção Ambiental, etc.

${ }^{7}$ Estrada Real também chamada dos Currais, Estrada do Sal, Picada da Bahia de acordo com a época e com a função que adquiria ao longo do tempo, foi aberta em 1730 e ligava a Bahia com Goiás e Mato Grosso. Ela cortava terras do Planalto Central que hoje pertencem ao Distrito Federal. Formosa/GO (antigo Arraial dos Couros); Planaltina/DF (antigo mestre d'Armas), Sobradinho/DF, Corumbá de Goiás/GO e Pirenópolis/GO (antigo Arraial de Meia Ponte) foram os primeiros povoados surgidos ao longo dessa estrada, que cruzava também a região de mineração da APA da Cafuringa e diversas sesmarias, colônias onde hoje está assentada Brazlândia.
} 
Com o declínio da mineração no final do XVIII, a economia passou a ter por base a agricultura e a pecuária. Com o objetivo de incentivar a formação de povoamento, as autoridades coloniais cediam sesmarias ${ }^{8}$ aos agricultores e mineradores.

Como é possível observar, a formação da população que vai constituir a Nova Capital, sofre intersecção de múltiplas culturas que vão conferir diferentes identidades aos seus diversos espaços. Planaltina é um exemplo, tendo como núcleo original o Setor Tradicional com sua arquitetura do século XVIII, convivendo com as interferências urbanas que afluíam com as migrações oriundas dos Estados do Brasil.

Bertran (1994) relata que no Diário de Viagem do quinto governador, General da Capitania das Minas de Goiás (1778-1783), Luís da Cunha Meneses faz referência a Mestre D’Armas, ferreiro e perito habilidoso que consertava as armas dos forasteiros que passavam pela região, e que gerou o nome daquela região formada por pequenas fazendas de gado e de agricultura de subsistência.

Conforme Bertran (1994), e baseados no registro do Livro de Impostos Rurais de Santa Luzia, atual Luziânia, afirma que em 1810, o Sítio de Mestre D’Armas era composto por sete sesmarias, abrigando cerca de 200 famílias. Em 1811, a população da região, sofrendo de uma epidemia ${ }^{9}$ e sentido a gravidade da situação, fez uma promessa para São Sebastião, prometendo-lhe que seria doado um pedaço de terra para a construção de uma capela caso a comunidade fosse livrada daquele mal. Após o milagre alcançado o Sítio passou a ser denominado de Arraial de São Sebastião de Mestre D’Armas. Passando o marco da fundação da cidade a ser o dia 20 de janeiro, dia de São Sebastião, padroeiro da cidade. Essa data perdurou até o ano de 1967, quando ocorreu a mudança da data de inauguração da cidade para o dia 19 de agosto (Decreto $n^{\circ} 571$ ).

Durante muito tempo a administração do território de Mestre D’Armas foi disputada pelas Vilas de Santa Luzia (Luziânia) e de Julgado de Couros (antigo nome de Formosa). A contenda provocou, por várias vezes, a alteração do nome do local e, várias anexações e desanexações levando o povoado a pertencer ora ao Julgado de Couros, ora a Santa Luzia, de acordo com as forças políticas e econômicas.

\footnotetext{
${ }^{8}$ As sesmarias eram terrenos incultos e abandonados, entregues pela Monarquia portuguesa às pessoas que se comprometiam a colonizá-los dentro de um prazo previamente estabelecido. O vocábulo sesmaria derivou do termo sesmar (avaliar, estimar, calcular) ou, ainda, poderia significar um território que era repartido em seis lotes, nos quais, durante seis dias da semana, exceto no domingo, trabalhariam nos sesmeiros.

${ }^{9}$ Não há registro da doença que provocou a epidemia, mas algumas doenças já eram conhecidas, tais como malária, diarreia, sífilis, hepatite, pneumonia, coqueluche, tuberculose, varíola, catapora, sarampo e uma gama de febres: tifoide e terçãs, ou as inflamatórias intestinais que se espalhavam pelo contato.
} 
Em 1859, quando foi criado o Distrito Municipal de Formosa, Planaltina desligou-se de Formosa e foi elevada à categoria de Vila de Mestre D'Armas, cuja instalação ocorreu em 20 de fevereiro de 1892 , com a aclamação da $1^{\circ}$ Intendência e com a inauguração da Cadeia Pública e da Escola, em 1893.

Naquele mesmo ano, em 1893, chega a Vila a Comissão Cruls ${ }^{10}$. Durante cerca de dois anos a Vila serviu de ponto de apoio para a Comissão que, ao final de suas pesquisas, elaborou um relatório técnico apontando as vantagens da localização da Nova Capital Federal na região. O Sítio de Mestre D’Armas ficou incluído nos limites do Quadrilátero demarcado pela Comissão Exploradora do Planalto Central. Recebeu o nome de Planaltina em 14 de julho de 1917, quando foram instaladas indústrias, empresas de curtume, fábrica de calçados, usina hidrelétrica e a estrada de rodagem ligando Planaltina a Ipameri/GO.

Em 1955, uma nova Comissão, delimitou a área e o sítio da Nova Capital. O quadrilátero do Distrito Federal aumentou, dividindo o território de Planaltina em duas partes. Uma parte que se encontrava sob jurisdição de Planaltina, abrangia todo o Plano Piloto e a maior parte do território onde hoje se constitui o Distrito Federal. A outra parte continuou a pertencer ao Estado de Goiás, com o nome de Planaltina de Goiás.

Com a inauguração de Brasília em 1960, Planaltina integrou-se à geografia e ao complexo administrativo da Nova Capital, ganhando infraestrutura urbana como luz elétrica, água encanada, telefone, transporte, dentre outros. A região continuou a receber moradores transferidos das diversas invasões formadas nas proximidades do Plano Piloto, provocando um rápido crescimento da população. Vários setores como Vila Vicentina, Setor Residencial Leste (Vilas Buritis I, II e III), Setor Residencial Norte A (Jardim Roriz) e o Setor Tradicional sofreram esse crescimento populacional.

Com isso, surgiu a necessidade de elaboração de um plano de urbanização com o objetivo de garantir uma ordenação estrutural e proteger o patrimônio cultural da cidade, capazes de comportar os novos moradores. Tais mudanças alteraram a organização dos espaços da cidade e das relações sociais, o que ocorreu também com o Setor Tradicional que, na atualidade, convive com os contrastes entre construções modernas e a conservação dos seus monumentos e de suas praças representadas pela Igreja São Sebastião ${ }^{11}$, o Casarão de

\footnotetext{
${ }^{10}$ Comissão responsável pelos primeiros estudos que culminaram com a demarcação de uma área de $14.400 \mathrm{~km}{ }^{2}$ (Quadrilátero Cruls) para a implantação da Nova Capital.

${ }^{11}$ A Igrejinha foi sede da paróquia desde seu estabelecimento em 1811, até a construção da nova Igreja Matriz, em 1980. Em 1911, ela sofreu sua primeira restauração.
} 
Dona Neguinha $^{12}$ e o Museu Histórico ${ }^{13}$ situados na Praça São Sebastião, a Casa das Artes ${ }^{14}$, o Casarão Azul ${ }^{15}$, a Casa do Idoso ${ }^{16}$, o Hotel "O Casarão"17 e o Colégio Franciscano Irmã Maria Assunta ${ }^{18}$, localizados na Praça Salviano Monteiro. Na parte tradicional da cidade foi acrescida uma nova área, o Setor Leste (Vila Buritis). Desde então a cidade tem sofrido inúmeras alterações urbanísticas com a implantação de loteamento para receber as invasões e a população de baixa renda de várias partes do país que não podem fixar se no Plano Piloto. Assim, foi criado o Setor Residencial A (Jardim Roriz) e ampliado o Setor Tradicional, conforme mapa da Região Administrativa de Planaltina, figura 4, mapa de Planaltina - RA VI.

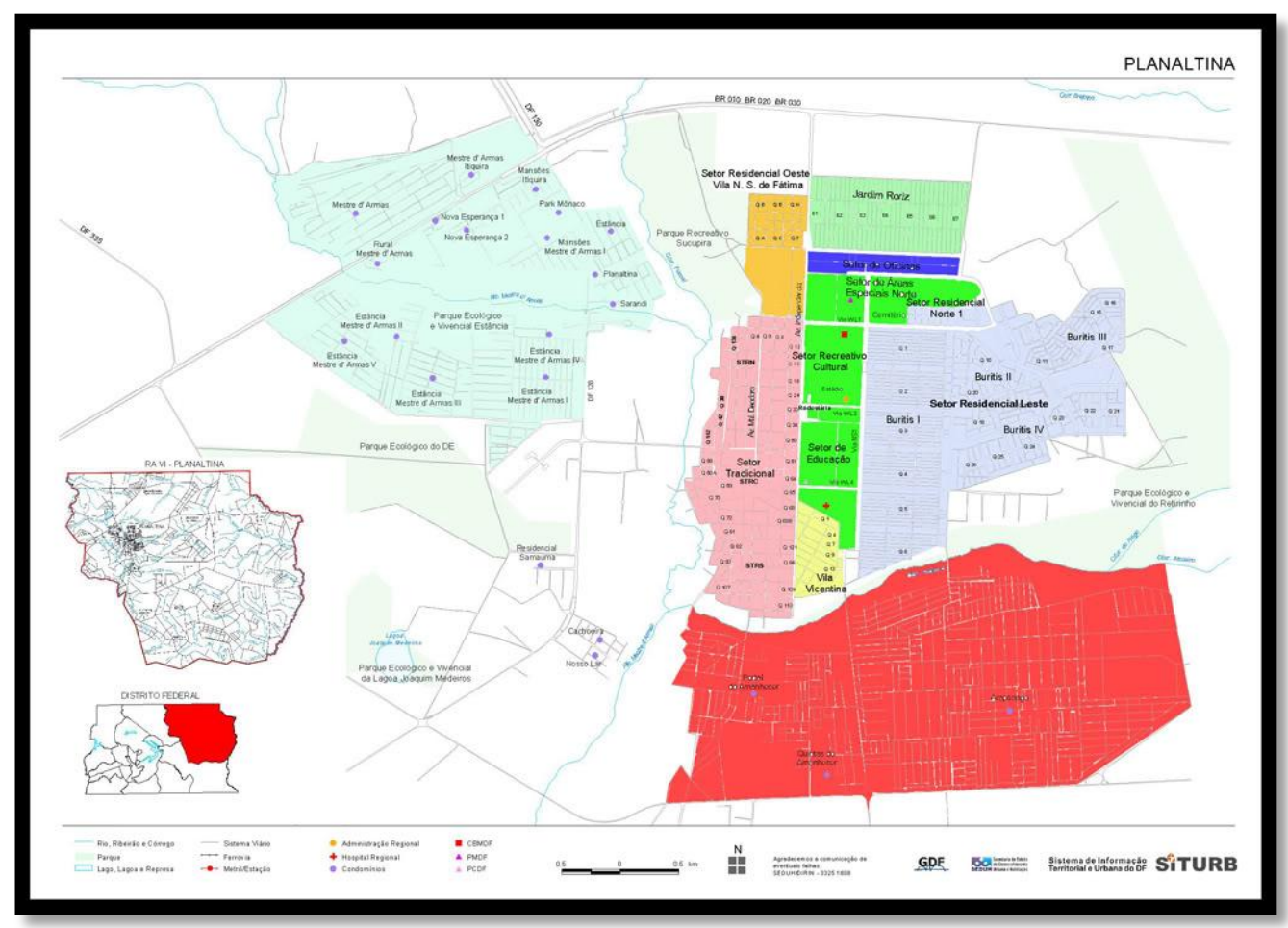

Figura 4. Mapa - Região Administrativa de Planaltina ${ }^{19}$ (RA VI). Distrito Federal, 2015.

\footnotetext{
${ }^{12}$ O Casarão de Dona Neguinha é uma casa antiga localizada na Praça de São Sebastião. Sua edificação é datada de $27 / 12 / 1945$.

${ }^{13}$ A casa onde se encontra o Museu Histórico e Artístico de Planaltina foi a residência da família Afonso Coelho Campos. Foi construída em 1905 e tombada em 1973, ano que abrigou uma exposição de objetos históricos de Planaltina. O acervo é composto por fotos e utensílios usados pelas famílias tradicionais.

${ }^{14}$ Localizada no Setor Tradicional, na Praça Salviano Monteiro, a Casa das Artes teve a sua construção por volta dos anos de 1926, é uma construção pós-colonial. O edifício já foi residência, loja de tecidos e utensílios domésticos e bar.

${ }^{15}$ O Casarão Azul data de 1921, foi usado como residência, hospedagem e hospital.

${ }^{16}$ Construída no final do século XIX foi comprada por Salvador Ribeiro de Freitas. Sua esposa, conhecida como Dona Morena, antes de morrer em 1983, pediu que a casa fosse transformada em uma instituição para o acolhimento de idoso e promoção de atividades direcionadas ao lazer dos idosos.

${ }^{17}$ Em 1922 o Hotel hospedou parte da Comissão do engenheiro Balduíno Ernesto de Almeida que veio assentar a Pedra Fundamental. Em 1961, o Hotel recebia muitos hospedes que trabalhavam na construção de Brasília.

${ }^{18} \mathrm{O}$ edifício do Colégio Franciscano Irmã Assunta ocupa uma área extensa com salas de aula, salas de reunião, banheiro e capela que era utilizada por alunos e professores. Atualmente o prédio é alugado para uma instituição privada.

${ }^{19}$ Fonte: http://www.skyscrapercity.com
} 


\subsubsection{A Escola - Centro Educacional 01 de Planaltina "Centrão"}

É nesse lugar, especificamente, no Centro Educacional 01 de Planaltina que foi realizada a pesquisa. O que hoje é denominado "Centrão" foi fundado em 1961, para atender a comunidade em nível ginasial. Com aumento da população estudantil, em 1973, o então Colégio de Planaltina transfere suas instalações físicas e passa a denominar-se Centro Educacional 01 de Planaltina. Atualmente, a principal característica da escola é a diversidade nas modalidades de ensino. A escola atende a população de Arapoanga, Buritis I, II e III, Estância, Vale do Amanhecer, Setor Sul, Mestre D’Armas, Vila Roriz e Setor Central.

Foi para lá que me dirigi! No percurso lembrava as aulas do curso de Pedagogia, principalmente, das lições de Paulo Freire (1982, p. 31): “O homem se identifica com sua própria ação: objetiva o tempo, temporaliza-se, faz-se homem-história”. Paulo Freire ensina a ação do homem como ser social e histórico de sua realidade, no seu agir no tempo e no espaço e concretizando transformações de sua realidade.

Paulo Freire também nos ensina que a escola é o espaço de diálogos, de projeto e de realizações transformadoras. Mas também, um lugar de cuidar do presente e do futuro, lugar de aprendizado e liberdade, um lugar de sonho e utopia. Sonho de uma sociedade mais justa e utopia como anuncio de um mundo melhor.

O nome "Centrão" é uma referência ao tamanho da escola. Cercada por um grande muro, no qual um dos lados traz a identificação da escola e a arte do grafite produzida pelos alunos, figuras 5, 6, 7 e 8 a seguir. Em seu interior, a escola é limpa e organizada. Os corredores das salas de aula são regulados para orientar o deslocamento de alunos e professores. A escola possui dois laboratórios de informática, e o melhor de tudo, funcionando perfeitamente. Um dos laboratórios é destinado à pesquisa e o outro e de livre acesso, ambos de uso dos professores e alunos. 


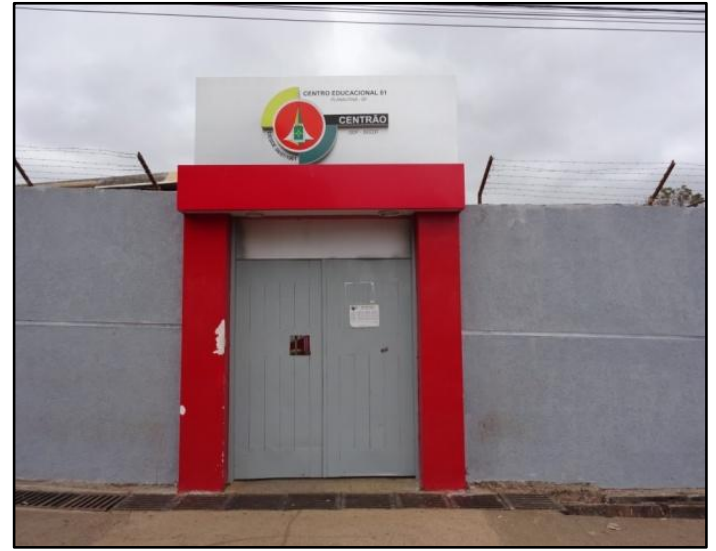

Figura 5. Muro: Entrada Principal - acervo da autora. CED 01 de Planaltina-DF, 2015.

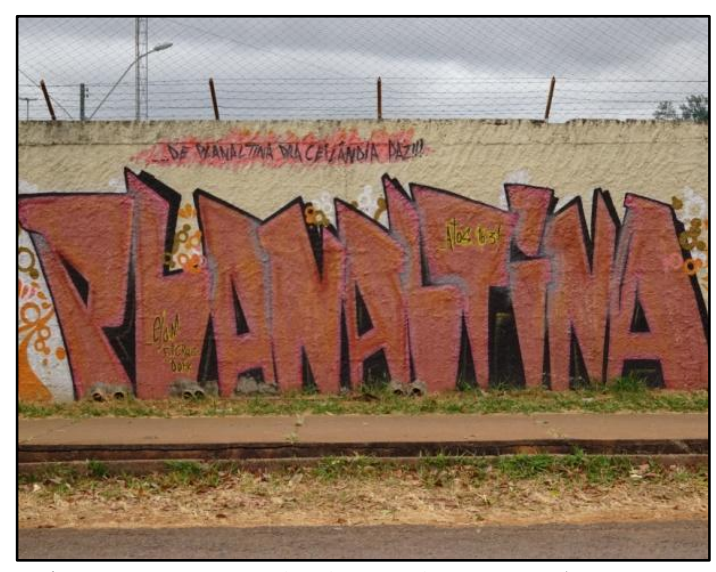

Figura 7. Muro: PLANALTINA - acervo da autora. CED 01 de Planaltina-DF, 2015.

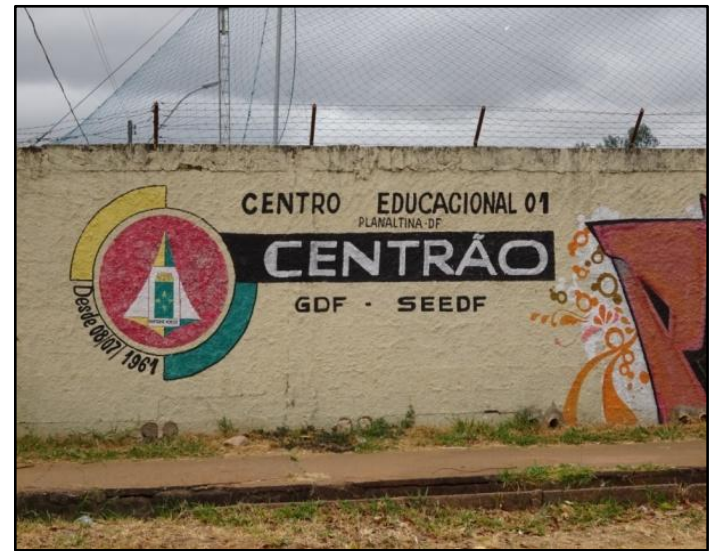

Figura 6. Muro: CENTRÃO - acervo da autora. CED 01 de Planaltina-DF, 2015.

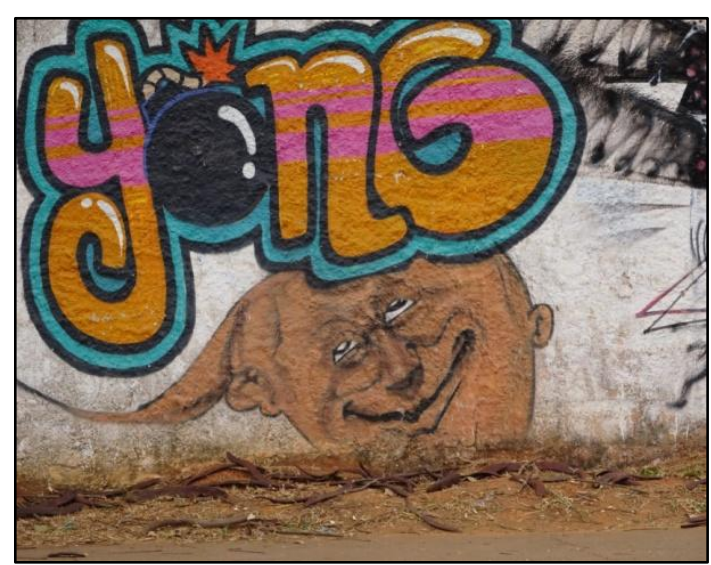

Figura 8. Muro: YONG - acervo da autora. CED $01 \mathrm{de}$ Planaltina-DF, 2015.

Em um dos blocos funciona o refeitório, provido de mesas e cadeiras para que os alunos possam fazer suas refeições. Cabe lembrar que o direito à alimentação escolar foi estendido aos alunos do Ensino Médio e da Educação de Jovens e Adultos, pela Lei no 11.947 de 16 de junho de 2009. A escola também oferece como opção para os alunos uma cantina particular.

O que mais chamou a atenção foi a limpeza dos banheiros destinados ao uso dos alunos: limpos, brancos com detalhe de ladrilhos na paredes, pias com bancadas, sabonete, papel toalha e papel higiênico. Tudo funcionando em perfeitas condições.

A escola possui vários espelhos como consta na figura 9, espalhados pelos corredores, que segundo a diretora, tem por objetivo refletir a imagem da comunidade do "Centrão", para que se olhem e se identifiquem como pessoas pertencentes a esse espaço de aprendizagem e de trocas de experiências. 


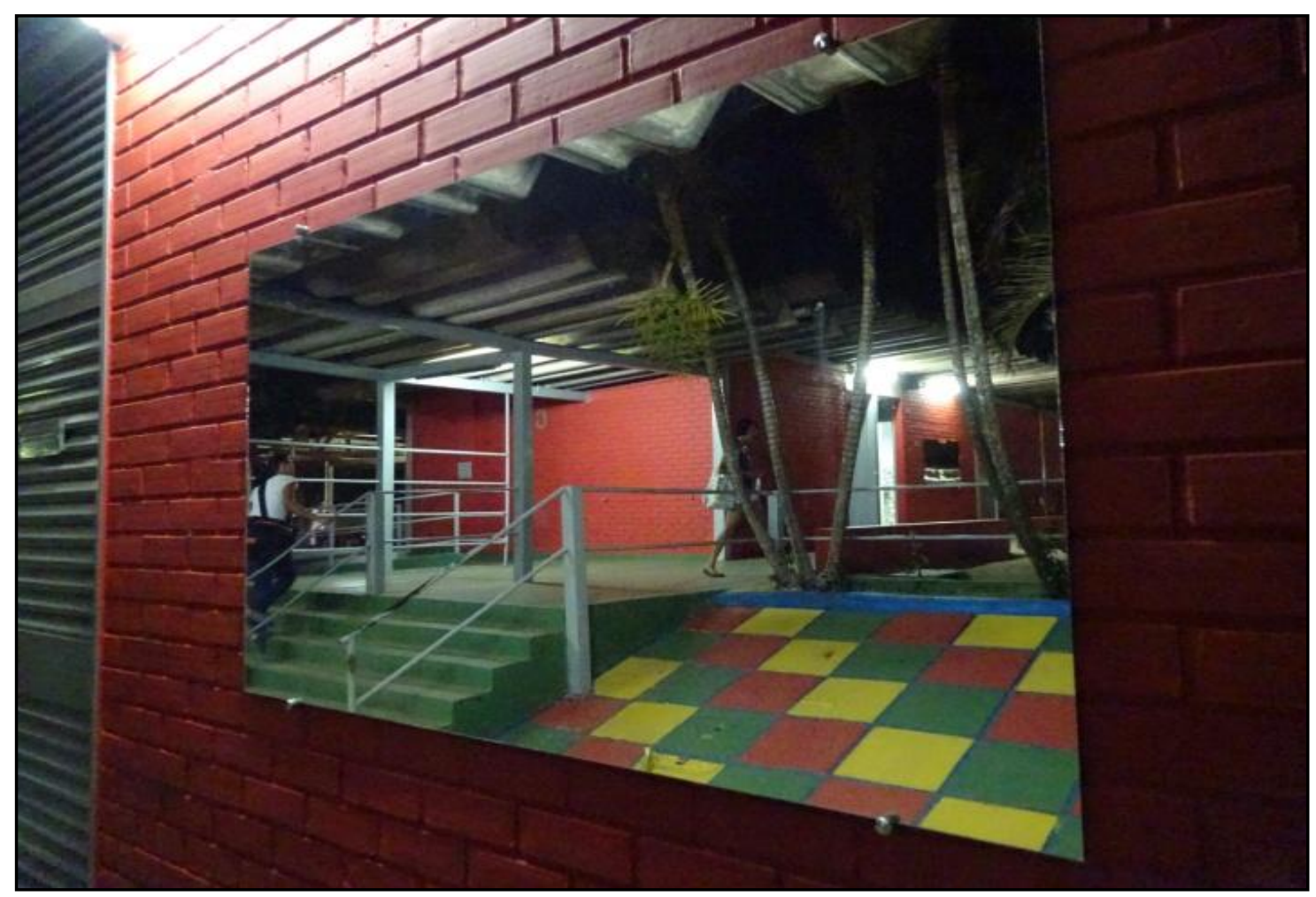

Figura 9. Espelho - acervo da autora. CED 01 de Planaltina-DF, 2015.

Diferentemente de outras escolas públicas, que no lugar do conhecimento, se encontram sujeiras, mato, infiltrações, problemas estruturais, fios expostos, pichação, enfim, do sucateamento da educação; a nossa primeira impressão é que no "Centrão" a organização do espaço escolar foi além da "maquiagem" que o torna um ambiente de aprendizagem acolhedor e digno.

\subsection{A Cidade de Ceilândia}

Ceilândia $^{20}$ é a maior Região Administrativa do Distrito Federal, em termos populacionais. A sua origem data do final da década de 1960, teve como objetivo inicial coibir a proliferação das favelas no Distrito Federal. Esse era um dos principais problemas enfrentados pelo Governo do Distrito Federal - GDF, que detectou cerca de oitenta e dois mil habitantes que ocupavam territórios estratégicos, nas proximidades do Plano Piloto. Por essa razão foi implantada a Campanha de Erradicação de Invasões - CEI, entre os anos de 1971 e 1972. Na época, o GDF cadastrou os barracos existentes nas vilas periféricas ao Núcleo

\footnotetext{
${ }^{20}$ Ceilândia (RA IX), segundo dados da Pesquisa Distrital por Amostra de Domicílios do Distrito Federal PDAD/DF - 2013, Ceilândia possui 451.872 habitantes, número esse, maior em quase o dobro de habitantes da segunda maior Região Administrativa de Samambaia (RA XII) com 228.356 habitantes.
} 
Bandeirante, transferidos para um novo espaço denominado Ceilândia ${ }^{21}$. Foram criados 17.619 lotes, de 10x25 metros, que deveriam acolher os moradores das invasões do IAPI, das Vilas Tenório, Esperança, Bernardo Sayão e Colombo; dos Morros do Querosene e do Urubu; Curral das Éguas e Placa das Mercedes.

Em meio à lama, poeira, falta de água e de trabalho foram transferidos, com a promessa de "legalização" dos terrenos a baixo custo e instalação de infraestrutura como escolas, água encanada e eletricidade. Ceilândia foi projetada em formato de barril e dividida originalmente em quatro grandes áreas: Ceilândia Norte, Ceilândia Centro, Ceilândia Sul e Guariroba. Conforme figura 10, mapa de Ceilândia.

Paviani (1987), ao interpretar a constituição do espaço urbano em Brasília, afirma que Ceilândia revela a construção injusta do espaço, pois a nova localidade não dispunha de lugares de trabalho, já que nas favelas e acampamentos da periferia do Núcleo Bandeirante, o trabalho estava próximo. Transferidos para Ceilândia, viram desestruturar o seu cotidiano, uma vez que passou a demandar demorados percursos para o trabalho, além dos gastos com os deslocamentos.

Para Wright (apud Paviani, 1987), a favelização histórica ao arredor da Nova Capital decorreu da transladação forçada dos favelados para lugares mais e mais distantes o possível do Plano Piloto, com a "erradicação das invasões".

Segundo Oliveira (2008), Ceilândia foi criada para receber as populações oriundas das remoções da Campanha para Erradicação de Invasões, que era inicialmente, um setor habitacional em Taguatinga que se ampliou. Apesar da vinculação da proximidade com a primeira cidade-satélite, sua malha urbana não é contínua e nem segue o mesmo desenho, é uma ampliação não integrada devido a um córrego que funcionou como uma faixa de "amortecimento" entre os dois núcleos. Para o autor, Ceilândia era vista como a segregação da segregação.

Como assinala Paviani (1987), os "invasores" são os sem-terra, os sem-teto e parte da massa de empobrecidos que se encontram em todas as grandes cidades brasileiras. São as vítimas da opressão gerada pela sociedade e da violência que contra eles se pratica. Para o autor, essa violência e opressão aparecem de forma camuflada como, por exemplo, compressão salarial, analfabetismo, doenças endêmicas, desemprego, subemprego, lacunas de trabalho, e todo tipo de segregação. Assim, a Nova Capital vai se formando com os mesmos

\footnotetext{
${ }^{21}$ O nome Ceilândia foi sugerido em 1970 pelo Secretário de Serviços Sociais Otomar Lopes Cardoso, oriundo da sigla CEI (Campanha de Erradicação das Invasões) acrescida da palavra "lândia", de origem norte-americana (land) para significar cidade.
} 
problemas de outras cidades e, na ânsia de organizar a espacialidade, termina por adotar uma política de marginalização da população de pobres e de trabalhadores informais.

Atualmente, Ceilândia sofre com sucessivas subdivisas e geram diversos outros bairros, como Setor “O”, Expansão, P-Norte, P-Sul, QNP e QNR, locais densamente povoados, além de abrigar dois condomínios urbanos irregulares em estágio avançado de consolidação: Sol Nascente e Pôr do Sol.

Assim, mesmo uma cidade planejada para o uso racional do espaço, como no caso de Brasília, não conseguiu prever as desvirtuações do seu plano diretor, já que a realidade impunha outra dinâmica plena de pluralidade de personagens, trajetórias, escolhas e direcionamentos.

O que nos leva a entender que a criação de cada cidade satélite do Distrito Federal é resultado de um processo histórico espacial com características próprias que as diferenciam.

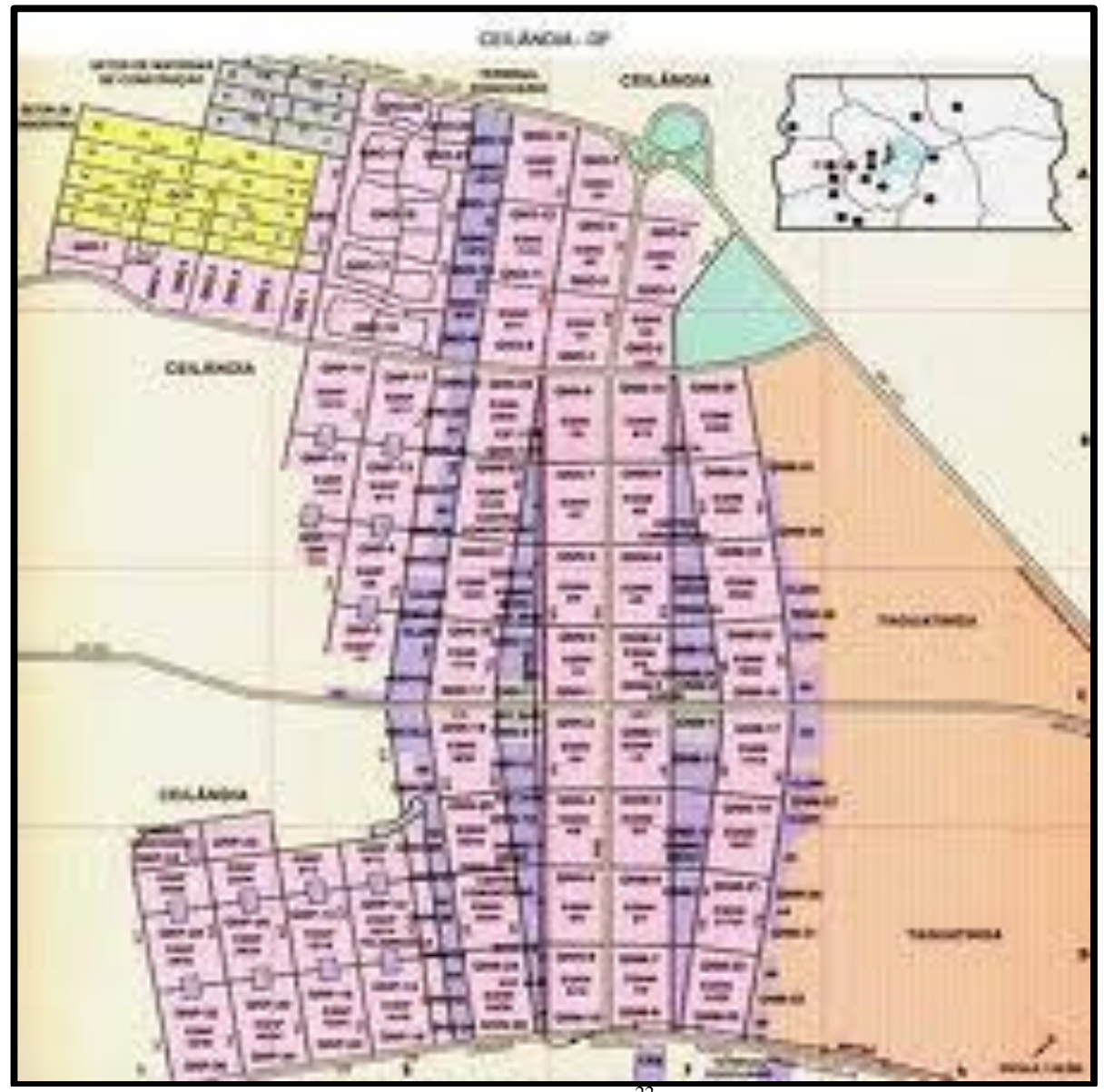

Figura 10. Mapa - Região Administrativa de Ceilândiaa ${ }^{22}$ (RA IX). Distrito Federal, 2015.

22 O projeto urbanístico da região é do arquiteto Ney Gabriel de Souza. São dois eixos cruzados em ângulo de 90 graus, formando a figura de um barril, conforme pode ser observado no mapa da região. Fonte do Mapa: google.com.br. 


\subsubsection{A Escola - Centro de Ensino Médio 03 de Ceilândia}

Desconhecia Ceilândia! O que sabia a seu respeito é que foi formada a partir de diversas favelas, então, na minha imaginação preconceituosa, pensava ser uma cidade feia, com uma escola pichada e alunos mal-educados. Qual foi a minha surpresa quando cheguei ao Centro de Ensino Médio 03! Um universo composto por aproximadamente três mil alunos, divididos nos turnos matutino, vespertino e noturno. Eles chegam ao CEM 03 oriundos de diversos locais: das quadras próximas, da Ceilândia Norte, Setor “O”, Setor "P”, Expansão, Recanto das Emas, Samambaia e Águas Lindas.

A Escola oferece o Ensino Médio nos três anos do ensino regular no turno matutino, para alunos em idade/série regular. O que mais me chamou a atenção é que a escola oferece Educação de Jovens e Adultos $\left(1^{\circ}, 2^{\circ}\right.$ e $3^{\circ}$ Segmentos $)$ no turno vespertino, aos alunos com distorção idade/série. No turno noturno, a escola possui quatorze turmas de EJA. O total dos alunos de EJA (1.864 alunos) nos turnos diurno e noturno ultrapassa a quantidade de alunos do Ensino Médio regular (1.052 alunos), o que confirma os dados do Censo Escolar de 2011 ao evidenciar que o país avançou em sua meta de universalizar o ensino e manter os jovens por mais tempo na escola; isto quer dizer que a evasão caiu, entretanto, a reprovação aumentou, atingindo 13,1\%, o maior número desde 1999. Esses dados justificam a situação encontrada no CEM 03 de Ceilândia.

Fisicamente, a escola possui espaços abertos internos, com gramados e árvores entre os blocos de sala de aula. Esses jardins são bem tratados, o que torna o ambiente de ensino e aprendizagem acolhedor e favorece a circulação da comunidade escolar.

A escola conta com trinta salas de aula, três laboratórios: um de informática e dois de ciências, um auditório e uma biblioteca, além do espaço administrativo (direção, sala de professores, secretaria e coordenação). As salas são divididas entre aquelas equipadas com bancadas e pias e outras com carteiras. Todas elas possuem ar condicionado. A escola é limpa, organizada e funciona atenta aos horários. O Projeto Político-Pedagógico - PPP da escola assegura que:

Infelizmente, ainda enfrenta-se o problema da resistência da maioria dos responsáveis em comparecer a escola para acompanhar a vida escolar do aluno. Os casos que mais necessitam de acompanhamento ainda causam certo transtorno pela falta de parceria entre escola e pais, o que gera um descontentamento por parte dos professores, direção e orientação educacional. Neste caso, um dos parceiros desta escola é o Conselho Tutelar, que atende prontamente ao nosso chamado (PPP/CEM 03, 2015). 
Diante de situações de insucesso acadêmico é comum as escolas e seus educadores responsabilizarem as famílias dos alunos por não assumirem a sua parte no processo educativo escolar. Entretanto, estudos como o de Szymanski (2003, p. 68), ressaltam ser comum ouvir os membros da equipe escolar afirmar, que as famílias são "desestruturadas, desinteressadas, carentes e, no caso de comunidade de baixa renda violentas". A autora afirma que por mais que os pais ausentes e desinteressados possam gerar desinteresse e afastamento de crianças e jovens das atividades escolares, existe uma generalização indevida dessa explicação.

Em seus muros a arte em grafite dos alunos do CEM 03, conforme figuras 11, 12, 13, e 14 .

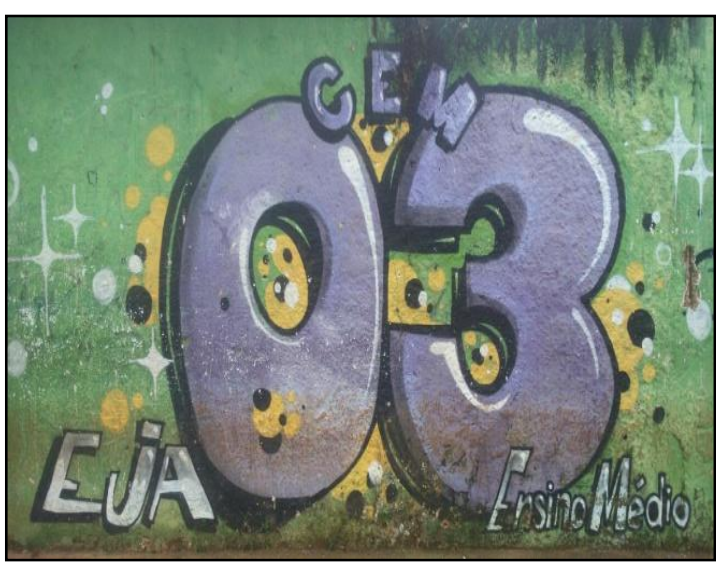

Figura 11. Muro: Entrada Principal - acervo da autora. CEM 03 de Ceilândia-DF, 2015.

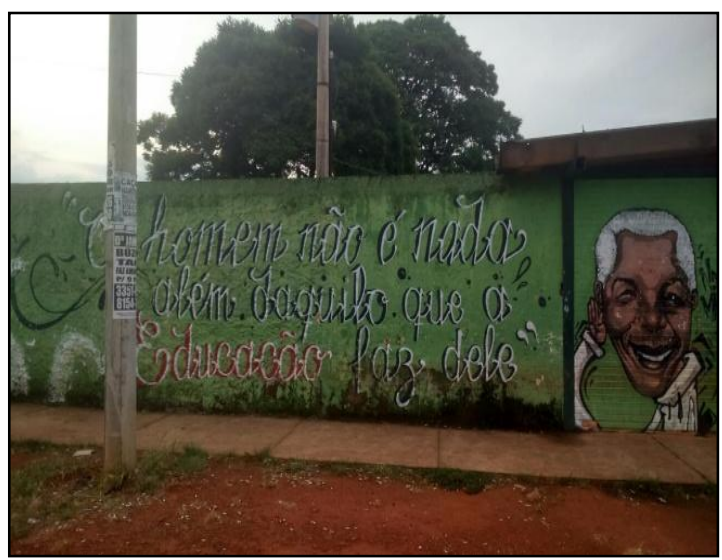

Figura 13. Muro: Immanuel Kant - acervo da autora. CEM 03 de Ceilândia-DF, 2015.

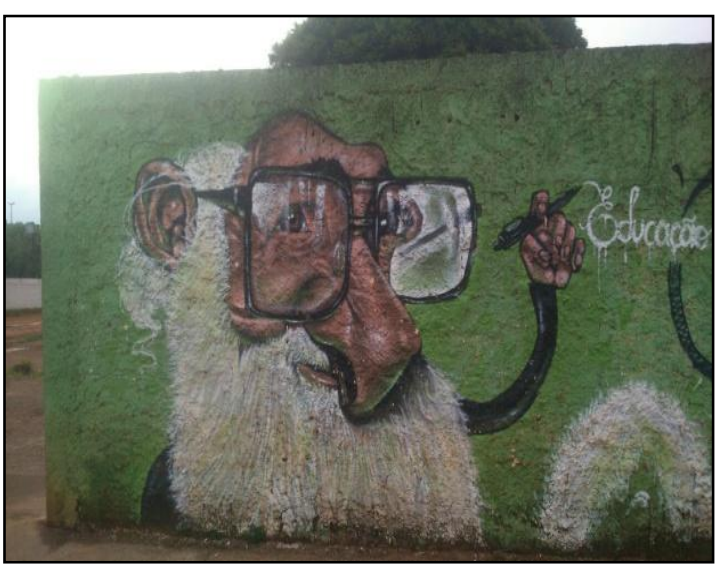

Figura 12. Muro: Paulo Freire - acervo da autora. CEM 03 de Ceilândia-DF, 2015.

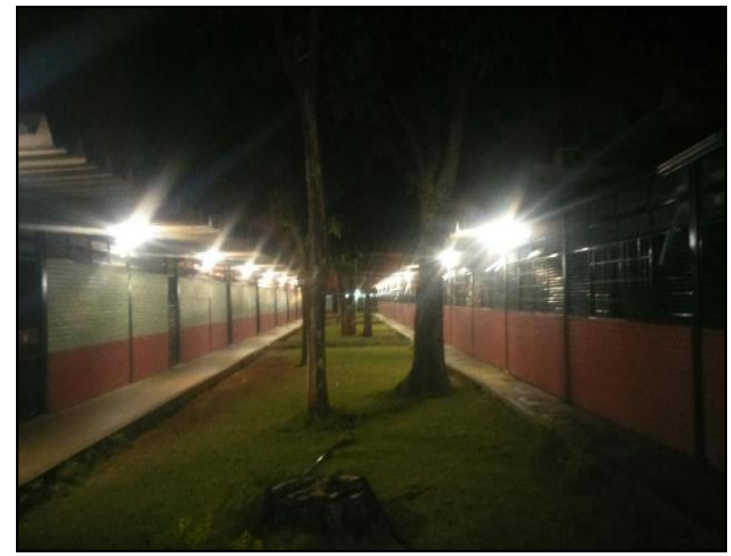

Figura 14. Interior da Escola - acervo da autora. CEM 03 de Ceilândia-DF, 2015. 


\section{OS ALUNOS DA PESQUISA}

Os alunos da Educação de Jovens e Adultos fazem parte de uma modalidade especifica da educação básica destinada à inclusão escolar de alunos que, por diversos motivos, foram excluídos, anteriormente, da educação.

São pessoas de experiências vividas que já desenvolveram suas crenças e seus valores. Diferentemente das demais modalidades de ensino, os alunos de EJA são jovens e adultos com diversos traços de vida, origens, idades, vivências profissionais, históricos escolares, ritmos e estruturas de aprendizagem. Vivem no mundo adulto do trabalho, tem responsabilidades sociais e familiares e formaram seus valores éticos e morais a partir da experiência e do ambiente da realidade cultural em que estão inseridos. Por isso, constituem uma diversidade muito grande, muitas vezes com baixo estima, buscam na EJA, o crescimento intelectual e profissional.

\subsection{A Educação de Jovens e Adultos}

A educação de Jovens e Adultos é uma modalidade de ensino, amparada por Lei e voltada para alunos que não tiveram acesso, por algum motivo, ao ensino regular na idade apropriada. Propõe-se atender um público ao qual foi negado o direito à educação durante a infância e/ou adolescência, seja pela oferta irregular de vagas, seja pelas inadequações do sistema de ensino ou pelas condições socioeconômicas desfavoráveis.

Numa perspectiva histórica, a educação de jovens e adultos torna-se um tema de política pública, a partir dos anos 40. Apesar de constar em textos normativos como, por exemplo, na Constituição de 1934, somente dez anos depois são concretizadas algumas iniciativas para oferta da escolarização aos que foram excluídos do sistema formal de ensino. Assim, em 1942, foi criado o Fundo Nacional de Ensino Primário e em 1947 o Serviço de Educação de Adultos e a Campanha de Educação de Adultos. Essas iniciativas continuaram na década de 50 com a fundação da Campanha de Educação Rural (1952) e Campanha de Erradicação do Analfabetismo (1958).

Dentre elas destacou-se a Campanha Nacional de Educação de Adultos, iniciada em 1947 como política governamental e com o entendimento da educação de adultos como peça fundamental para alavancar os níveis escolares da população. Beisiegel (2004), acredita que essa campanha assumiu papel indutor, provocando a iniciativa das unidades federadas por 
meio da regulamentação da distribuição de fundos públicos para a estruturação tanto da educação primária como para os jovens e adultos. Segundo Ribeiro (1997), essa orientação política viabilizou a criação e permanência do ensino supletivo integrado às estruturas dos sistemas estaduais de ensino, dando lugar à instauração no Brasil de um campo de reflexão pedagógica em torno do analfabetismo e suas consequências psicossociais, apesar de não ter produzido nenhuma proposta metodológica específica para a alfabetização de adultos.

Um modelo pedagógico próprio para a educação de jovens e adultos surgiu na década de 60 com Paulo Freire. Suas ideias passaram a nortear as experiências de educação de adultos nas diversas ações, como por exemplo, o Movimento de Educação de Base (MEB), o movimento de Cultura Popular do Recife em 1961, os Centros Populares de Cultura da União Nacional dos Estudantes. Ribeiro (1997) assinala que embaladas pela efervescência política e cultural do período, essas experiências evoluíam no sentido da organização de grupos populares articulados a sindicatos e outros movimentos sociais.

O destaque da pedagogia de Paulo Freire foi preconizar a urgência de uma educação de adultos de forma crítica, voltada para a transformação social e não apenas à adaptação da população a processos de modernização conduzidos por forças exteriores. O método consistia no diálogo como princípio central do processo educativo com o objetivo de despertar nos educandos adultos a consciência de seu papel de sujeito de aprendizagem, de produção de cultura e de transformação do mundo.

No ano de 1964 inicia o fechamento político e institucional que leva ao desaparecimento dessas ações educativas inspiradas no modelo freireano, ficando a educação de adultos sob a responsabilidade das igrejas, associações de moradores, organizações de base e outros espaços comunitários.

A educação de adultos voltou a ser preocupação governamental somente a partir de 1969, quando foi organizado o Movimento Brasileiro de Alfabetização - MOBRAL, atuando em nível nacional e voltado para a alfabetização dos adultos. Segundo Paiva (1982), o MOBRAL procurava, por um lado responder aos marginalizados sistema escolar e, por outro atender aos objetivos políticos dos governos militares. Como objetivos do programa Paiva afirma que:

Buscava-se ampliar junto às camadas populares as bases sociais de legitimidade do regime, no momento em que ela se estreitava junto às classes médias em face do AI5 , não devendo ser descartada a hipótese de que tal movimento tenha sido pensado também como instrumento de obtenção de informações sobre o que se passava nos municípios do interior do país e na periferia das cidades e de controle sobre a população, ou seja, como instrumento de segurança interna (PAIVA, 1982, p. 99). 
O programa foi executado diretamente pelo Ministério da Educação com amplos recursos na montagem, controle e centralização desde a orientação e supervisão pedagógica até a produção de material didático. A intenção era que o MOBRAL fosse uma ação que seria finalizada após a extinção do analfabetismo no Brasil. Para Haddad (1991), o MOBRAL contribui para legitimar a nova ordem política e respondia às orientações de agências internacionais ligadas à Organização das Nações Unidas - ONU, principalmente a Organização das Nações Unidas para a Educação, a Ciência e a Cultura - UNESCO, que defendia o combate ao analfabetismo e a universalização de uma educação elementar como estratégia de desenvolvimento socioeconômico e manutenção da paz.

Apesar dos recursos do governo federal, o MOBRAL foi muito criticado por não ser capaz de desenvolver o domínio rudimentar da escrita. Totalmente desacreditado foi extinto em 1985. A sua estrutura foi assimilada pela Fundação Educar de apoio técnico e financeiro às iniciativas de governos estaduais e municipais e entidades civis.

A partir desse momento histórico, a Fundação Educar abria mão do controle político pedagógico, e, vários programas acolheram educadores ligados à experiência de educação popular. Haddad (1991) observa que nesse período foi possível a confluência do ideário da educação, até então desenvolvido nas experiências de educação não formal com a promoção da escolarização de jovens e adultos por meio de programas mais extensivos da educação básica.

A Lei Federal 5692/71, consagrava a extensão da educação básica obrigatória de 4 para 8 anos (primeiro grau) e dispôs as regras básicas para o provimento de educação supletiva aos jovens e adultos. Assim, pela primeira vez, a educação de jovens e adultos teve um enquadramento legal, distinguindo as suas funções como de suplência, relativa à reposição de escolaridade; o suprimento, relativo ao aperfeiçoamento ou atualização; e a aprendizagem e qualificação, referentes à formação para o trabalho e profissionalização. Era previsto também, a flexibilidade para aqueles que não haviam realizados ou completado na idade própria a escolaridade obrigatória. O resultado é que a educação de jovens e adultos se proliferou de diversas formas: cursos supletivos, centros de estudo e ensino a distância, cada qual com sua característica específica.

Nos cursos supletivos vigorava a seriação, a presença obrigatória e a avaliação no processo, entretanto, o aluno podia acelerar o tempo estipulado para a conclusão de um grau de ensino. Nos centros de estudo era oferecido o material didático em módulos e sessões de estudos; a frequência era livre, a avaliação feita periodicamente por disciplina e módulo. Uma 
das primeiras experiências de educação a distância foi realizada via televisão em regime de livre recepção, em tele postos que combinavam a reprodução de programas em vídeo, uso de materiais didáticos impressos e acompanhamento de monitores. Além dessas possibilidades, também eram previstos os exames supletivos periódicos como mecanismo de certificação, sem a exigência ou frequência à sala de aula.

Estudos realizados por Beisiegel (1999) apontam que a extensão da escolaridade obrigatória para oito anos, proposta pela Lei 5692/71, representava um enorme desafio, já que colocava em condição de déficit educativo um enorme contingente da população adulta, à qual o ensino supletivo estaria a serviço. Entretanto, essa mesma legislação limitou a obrigatoriedade da oferta pública do ensino de primeiro grau apenas às crianças e adolescente na faixa etária de 7 a 14 anos.

O Direito à educação básica aos jovens e adultos somente foi ampliado pela Constituição Federal de 1988. Haddad (1991) afirma que na época da promulgação do texto constitucional, o ensino supletivo já tinha sido implantado em todo território nacional de modo heterogêneo. Observa também, que a insuficiência da cobertura da demanda, a dificuldade de ordem política, administrativa, financeira e pedagógica, limitavam a extensão e a qualidade do ensino oferecido. Assim, passou a predominar a oferta por meio de modalidades não presenciais, nas quais a baixa interação professor-aluno e a flexibilidade de organização se associavam a baixos custos de funcionamentos.

Haddad (1991) chama a atenção para o fato de que os programas correspondentes às séries iniciais (Suplência I) deram sequência as experiências de alfabetização influenciadas por Paulo Freire, o que determinou alguma identidade pedagógica, com maior liberdade tanto no que se refere aos promotores e locais de funcionamento dos cursos quanto à duração e periodização das etapas.

Já os cursos de Suplência II (Séries Finais do Ensino Fundamental) eram submetidos as regulamentações impostas pelos Conselhos de Educação. Para o autor, existe uma homogeneidade na reprodução dos conteúdos do ensino regular, na organização das disciplinas e na sequência; entretanto, são poucas as experiências inovadoras em termos de desenvolvimento de novos eixos curriculares e novas formas de organizar os tempos e espaços de aprendizagem.

Ainda para Haddad (1991), a dificuldade de construção de uma identidade pedagógica do ensino supletivo e de sua adequação às características específicas da população a que se destina é a juvenilização da clientela. O modelo de inspiração freireana, que serviu como 
referência para educadores aproximarem o ensino da realidade dos alunos, tinha como foco os educandos trabalhadores e adultos desescolarizados, que mesmo morando nas grandes cidades, mantinham vínculos com uma cultura rural.

Atualmente, a clientela dos cursos de Educação de Jovens e Adultos torna-se cada vez mais jovem e urbana, em função da dinâmica escolar brasileira e das pressões do mundo do trabalho. Dessa forma, a EJA passou a ser também um mecanismo de aceleração de estudos para adolescentes e jovens com baixo desempenho no ensino regular.

Haddad (1992) afirma que falar sobre a Educação de Jovens e Adultos no Brasil é o mesmo que falar sobre os males do sistema público regular de ensino e das precárias condições de vida da maioria da população. Para o autor, a EJA é uma educação para os pobres, para jovens e adultos das camadas populares, para os excluídos do desenvolvimento e dos sistemas educacionais de ensino, no entanto, se constitui como uma oportunidade de melhoria das condições de vida, de superação da exclusão.

Por isso, segundo Haddad (1992), uma massa considerável de excluídos do sistema formal de ensino, seja por se encontrarem em condições de vida precárias, seja por terem tido acesso a uma escola de má qualidade, ou mesmo não terem tido acesso à escola, acaba por se defrontarem com a necessidade de realizar sua escolaridade onde o domínio do conhecimento ganha cada vez mais importância.

\subsection{Percurso da Pesquisadora - CED 01 de Planaltina}

O primeiro contato na Região Administrava de Planaltina foi com a Coordenação Regional de Ensino (CRE da Secretaria de Estado de Educação do Distrito Federal). Portando os ofícios da Universidade de Brasília e da Escola de Aperfeiçoamento dos Profissionais de Educação (EAPE) que me permitiam adentrar a escola e realizar a pesquisa. A opção foi por uma turma de EJA do terceiro segmento, no turno noturno, na disciplina de Arte.

No dia 09/09/2015, me encaminhei à escola, onde fui recebida pela diretora do Centro, Professora Nedma Guimarães, que recomendou a turma da Primeira Etapa do Terceiro Segmento de EJA, da professora Nitiana. A professora cedeu o $2^{\circ}$ horário (20h às 20h:45). Horário ideal para a instalação dos equipamentos e arranjo das cadeiras em círculos.

O primeiro momento com a turma de 20 alunos aconteceu no dia 28/09/2015, quando apresentei o projeto de pesquisa para os alunos e apliquei o questionário. Apesar do curto tempo de aula, foi possível provocar os alunos com algumas perguntas: como vocês olham a 
cidade de Planaltina? Como vocês se olham na cidade em que moram? Eles permaneceram em silêncio, eu continuei a perguntar: como vocês olham o futuro da cidade? Apenas um aluno respondeu: "Essa cidade não tem nada de interessante". Eu respondi já no término da aula, que nos próximos encontros verificaríamos o fundamento da resposta do aluno.

Em 05/10/2015, o segundo momento deu-se início às narrativas visuais por meio de produções de desenhos, colagem, textos ou qualquer outra forma pelos alunos, sobre o tema "Lugares de lembrar a infância". Os alunos podiam escolher como representar a infância no papel. Para tanto, foi disponibilizado todo o material didático (papel, lápis de cor, giz de cera, canetas hidrográficas, colas, tesouras, jornais, revistas etc.) para livre manuseio. Quinze alunos participaram da aula, e nesse momento, foi informado que havia sido criado um grupo no WhatsApp e um endereço de e-mail para quem quisessem enviar fotografias da cidade, com o intuito de que os alunos olhassem a cidade e registrassem em suas passagens pelas ruas, as percepções sobre o espaço urbano onde vivem. A maioria aderiu à ideia do grupo no WhatsApp. Tanto o grupo do WhatsApp, como o de e-mail possuíam o nome de Visualidades - CED 01 de Planaltina.

O terceiro momento foi adiado em virtude da greve dos professores, que durou vinte e nove dias. Quase dois meses após o primeiro encontro, o retorno ao estudo foi reiniciado em 23/11/2015. Apesar das trocas de mensagens e envio de fotografias por parte dos alunos pelo WhatsApp, observei que houve uma ruptura que colocava em risco todo o trabalho. Por isso, com muito cuidado fiz uma pequena rememoração do que foi realizado. Trabalhamos naquele dia o tema "Lugares de lembrar a cidade e sua inserção". Percebi que vários alunos preferiram representar por meio de desenhos, colagens de gravuras de jornais e textos na forma como eles olham a cidade hoje: o agora.

Mais uma interrupção com o feriado do dia do evangélico. Duas semanas depois, em 07/12/2015, foi trabalhado o último tema "Lugares de sonhar: perspectivas futuras". Percebi ao mesmo tempo, um silêncio e uma reflexão das prioridades dos sonhos. Todos tinham sonhos, eles só não sabiam por onde começar. Nessa aula apenas treze alunos participaram das atividades.

Observei que após a greve, vários alunos não voltaram para a escola, mesmo com as medidas adotadas pela direção do Centro em informar por meio de telefonemas o encerramento da greve dos professores. Situação semelhante encontrada no CED 01 de Planaltina após a greve foi tema da reportagem do Jornal da Band, da Rede Bandeirantes de TV, do dia 2 de junho de 2015, sobre a greve de professores da rede pública em cinco Estados 
brasileiros, afirmando que uma das consequências das constantes paralisações são alunos desmotivados e o aumento da evasão escolar.

Sobre a evasão na EJA, Haddad (2007, p. 205) afirma que é elevada em programas de EJA, em função não só de fatores internos aos processos de ensino e aprendizagem, mas também por fatores externos vinculados às difíceis condições de vida dos alunos: as dificuldades de aprendizagem e as condições financeiras que fazem com que jovens e adultos cumpram jornadas de trabalho árduas; dificuldades de conciliar a escola, família e trabalho; entre outros motivos que levam os jovens a evadir.

A evasão no CED 01 de Planaltina pode ser observado na lista de chamada da turma composta por 29 alunos, evidenciando um fluxo irregular de presença: no dia 28/09/2015 (1 ${ }^{\circ}$ momento) contava com 20 alunos $68 \%$ da turma no início do semestre, no dia 05/10/2015 (2 momento) com 15, no dia 23/11/2015 ( $3^{\circ}$ momento) com 11 e no dia 07/12/2015 (4 momento) 13 alunos; o semestre terminou com a presença de apenas $32 \%$ da turma.

As figuras 15 e 16 trazem fotografias de dois momentos de sala de aula e da turma de Planaltina.

Apesar da greve e dos constantes feriados a pesquisa de campo no CED 01 de Planaltina foi concluída com trinta e nove narrativas visuais. Sendo apreendidas oito narrativas de alunos que concluíram os quatros momentos da prática pedagógica, constituindo assim, o portfólio com vinte quatro narrativas visuais, além de mensagens enviadas pelo aplicativo WhatsApp, expostas no capitulo intitulado 5.1. Narrativas Visuais dos alunos do CED 01 de Planaltina.

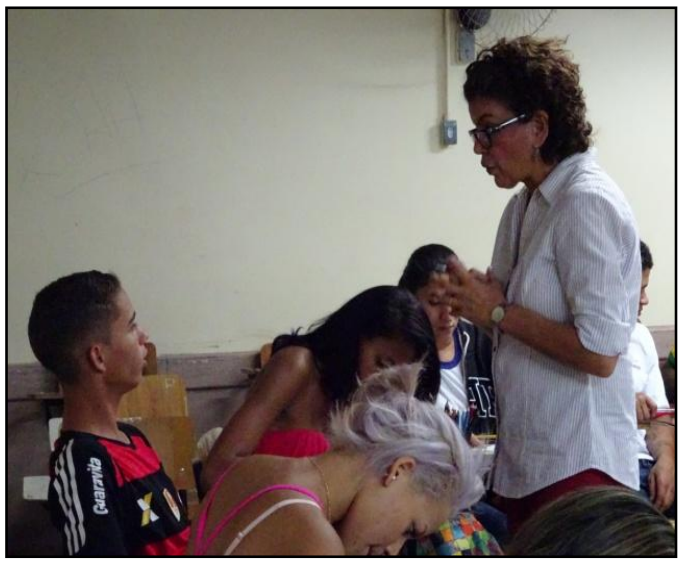

Figura 15. Sala de Aula - acervo da autora. CED 01 de Planaltina-DF, 2015.

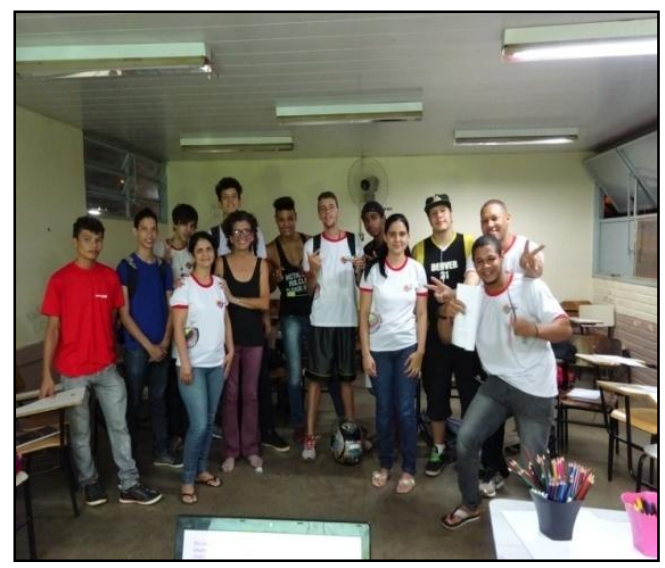

Figura 16. Turma - acervo da autora. CED $01 \mathrm{de}$ Planaltina-DF, 2015. 


\subsection{Percurso da Pesquisadora - CEM 03 de Ceilândia}

Na Região Administrativa de Ceilândia o procedimento adotado foi o mesmo de Planaltina. No dia 11/09/2015, fui recebida pelo Diretor da escola Divaldo de Oliveira, que juntamente com a Coordenação Pedagógica do Centro de Ensino Médio 03 de Ceilândia, me encaminharam para uma turma da Primeira Etapa do Terceiro Segmento de EJA, no turno noturno.

O professor da turma de Arte, Ney Cirqueira, me recebeu com muito carinho, principalmente quando descobrimos uma coisa em comum: ele foi aluno da minha orientadora na graduação. O professor reprogramou suas aulas, tendo em vista que ele atuava na Linguagem Cênica e cedeu o espaço na turma para a pesquisa em Artes Visuais.

Também, em Ceilândia, foi liberado o segundo horário para que eu pudesse organizar a sala de aula. Assim, no dia 07/10/2015, aconteceu o primeiro encontro para apresentação do projeto de pesquisa e a aplicação do questionário para os dezoito alunos presentes. Da mesma maneira, indaguei aos alunos de como eles olham e se olham na cidade que eles moram, percebi com isso que os alunos de Ceilândia são mais falantes. Falaram muito sobre a violência, drogas e falta de segurança. Informei sobre o grupo de WhatsApp e do endereço de e-mail, Visualidades - CEM 03 de Ceilândia, para quem quisesse fotografar os espaços urbanos e enviar fotos da cidade. Para minha surpresa, o número de alunos que aderiu à ideia foi menor que em Planaltina, apenas sete alunos.

A respeito da greve dos professores, o CEM 03 de Ceilândia aderiu de forma parcial, não havendo assim, ruptura dos momentos de aulas.

No segundo momento, iniciou-se a prática pedagógica com o tema "Lugares de lembrar a infância", no dia 21/10/2015, com a participação de dezessete alunos.

No dia, 28/10/2015, terceiro momento, foi trabalhado o tema "Lugares de lembrar a cidade e sua inserção na cidade", com a participação de quinze alunos.

No quarto encontro, dia 04/11/2015, quatorze alunos trabalharam o tema "Lugares de sonhar: perspectivas futuras", e percebi a dificuldade de projetarem o futuro e as expectativas futuras.

Lembrei-me da pesquisa de Oliveira e Saldanha (2010), com 296 estudantes do ensino fundamental e médio das escolas públicas e privadas. $\mathrm{O}$ trabalho consistia numa resposta discursiva à seguinte pergunta: "Como você vê seu futuro?" As pesquisadoras observaram que os estudantes diferem em poucos itens, como por exemplo, ingressar em uma 
universidade ou confiar nos dirigentes do país, ao passo que se assemelham na maioria, como conclusão dos estudos e conseguir emprego que trouxesse qualidade de vida. A conclusão das autoras foi de que os estudantes de escolas públicas e privadas diferem em poucas questões e possuem aspirações similares quanto à forma como idealizam o futuro.

Em Sobrosa et all (2014), as autoras investigaram as expectativas em relação ao futuro profissional de 200 jovens estudantes do Ensino Médio, de duas escolas públicas estaduais no interior do Rio Grande do Sul, oriundos de classes socioeconômicas desfavorecidas. Constatou-se que a maioria dos estudantes acredita que seu futuro profissional está relacionado tanto ao esforço pessoal para conquistar sucesso profissional e pessoal e boas condições financeiras, quanto a exercer uma profissão que lhes traga satisfação pessoal.

As autoras observaram que os jovens são otimistas em relação ao futuro profissional e esperam conquistar sucesso nos diversos contextos de vida. No entanto, os participantes reconhecem a necessidade de se esforçarem para atingir seus objetivos e desfrutarem da satisfação que o trabalho pode proporcionar, uma vez que percebem os aspectos negativos associados à instabilidade do mercado de trabalho.

No CEM 03, em todos os momentos de aula foram percebidas uma diminuição do número dos alunos. A lista de presença no início do semestre constava de trinta e dois alunos, no final do semestre restavam apenas quatorze alunos, percentual de $65 \%$ de desistência.

Os estudos realizados pelo Fundo das Nações Unidas para a Infância - UNICEF, em parceria com a Campanha Nacional pelo Direito à Educação, constataram que o trabalho infantil, o fracasso escolar, as desigualdades sociais e a baixa renda das famílias são fatores determinantes para a evasão escolar de crianças e adolescentes. Bem como a Pesquisa Nacional por Amostra de Domicílios - PNAD (2009), informa que cerca de 3,7 milhões de meninos e meninas entre 4 e 17 anos de idade estão fora da escola no Brasil.

Muitos são os fatores que cooperam para a evasão escolar e podem ser provocados dentro da própria escola, como a repetência escolar motivada muitas vezes pela falta de uma didática adequada; condições precárias na estrutura física da escola, via de regra esquecida pelos governantes federais, estaduais e municipais; dificuldades de acesso a instituição de ensino; a inexistência de transporte público para conduzir o estudante até a escola; espaço físico sem mobiliário e material didático básico; e falta de merenda escolar, são outros aspectos que podem ser decisivos para manter o estudante dentro da sala de aula.

Em Ceilândia, como não houve adesão total à greve dos professores, foi possível fazer um quinto encontro: a confraternização com os alunos, uma forma de agradecer o carinho e a 
disposição em participar da pesquisa. Compartilhamos bolo e refrigerante, enquanto apresentava para os alunos os registros dos momentos em sala por meio de fotografias expostas em slides, e parte da pesquisa apresentada na Conferência de Artes Educadores do Brasil - CONFAEB, ocorrido em Fortaleza-CE nos dias 05 a 08 de novembro de 2015, em que participei como comunicadora. Após a exibição do texto e fotografias, foi possível perceber o sentimento de importância e autoestima ao ter alguém preocupando-se com eles: "Estava em Fortaleza e nem sabia" (fala de um dos alunos). As fotografias a seguir são dos momentos de sala de aula da prática pedagógica e da confraternização, figuras 17, 18, 19 e 20 .

A pesquisa em Ceilândia foi concluída com quarenta e seis narrativas visuais, sendo que, dos dezoito alunos participantes, treze participaram dos quatros momentos da prática pedagógica, totalizando 39 narrativas visuais, além das mensagens enviados pelo aplicativo do WhatsApp, expostas no capitulo 5, subtítulo 5.2. Narrativas Visuais dos alunos do CEM 03 de Ceilândia.

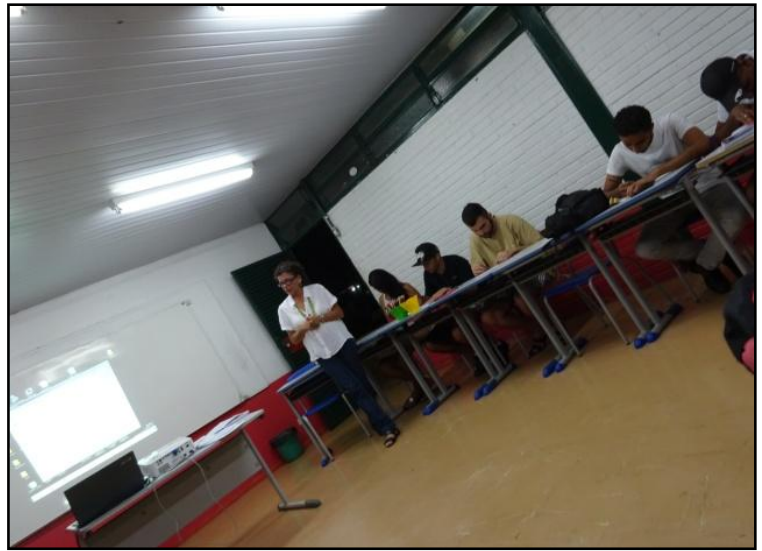

Figura 17. Sala de Aula - acervo da autora. CEM 03 de Ceilândia-DF, 2015.

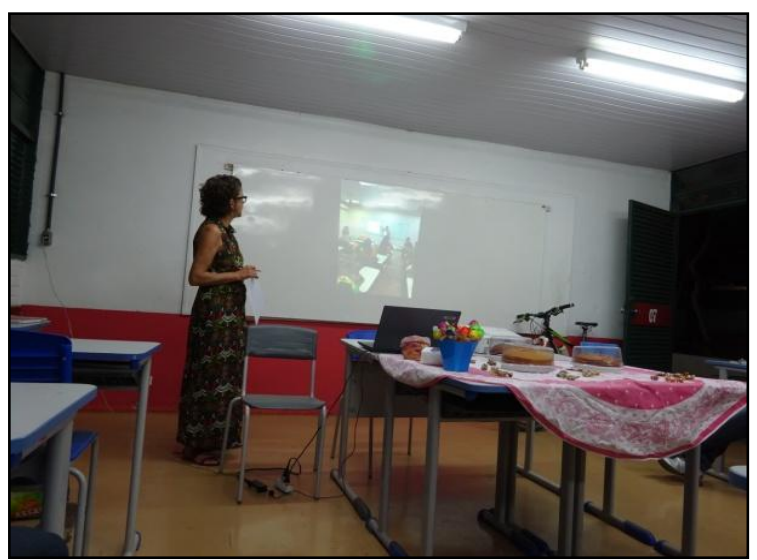

Figura 19. Confraternização - acervo da autora. CEM 03 de Ceilândia-DF, 2015.

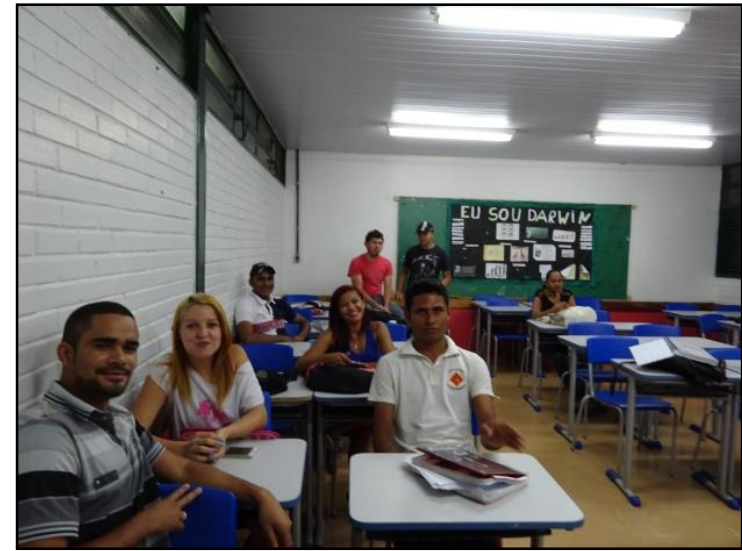

Figura 18. Sala de Aula - acervo da autora. CEM 03 de Ceilândia-DF, 2015

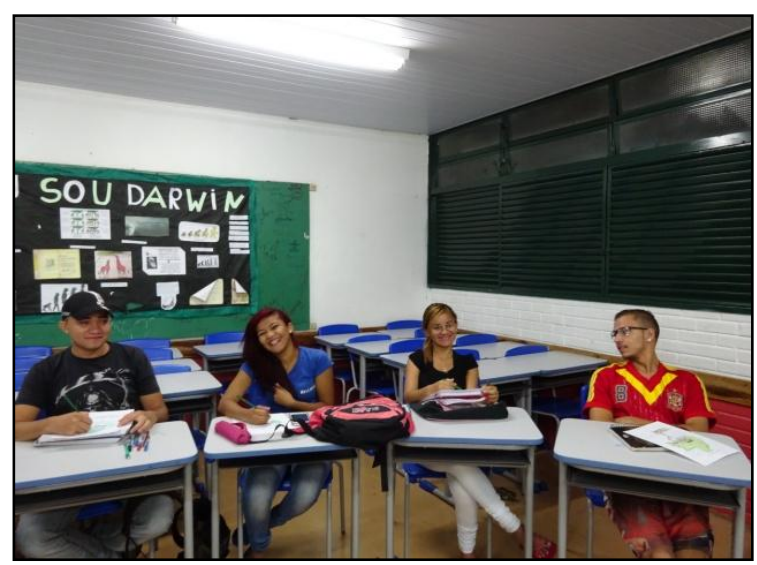

Figura 20. Sala de Aula - acervo da autora. CEM 03 de Ceilândia-DF, 2015. 


\section{METODOLOGIA DA PESQUISA}

Para a pesquisa elegeu-se a metodologia qualitativa que pode ser aplicada a vários estudos. Como sinalizam Lüdke e André (2012), uma das características básicas da metodologia é ter o ambiente natural como fonte direta de dados e o pesquisador como seu principal instrumento. A metodologia qualitativa é baseada na ideia de que os indivíduos têm uma visão sensorial subjetiva e situacional do mundo, ao invés de enxergá-los como uma verdade objetiva. Por isso, ela supõe o contato direto do pesquisador com o ambiente e a situação onde o fenômeno a ser investigado ocorre.

Para os autores, a pesquisa qualitativa é rica em dados descritivos, com um plano aberto e flexível, que a realidade é entendida de forma complexa e contextualizada, constituindo para o observador um desafio, com capacidade para:

[...] tolerar ambiguidades, capaz de trabalhar sobre sua própria responsabilidade, inspirar confiança, comprometido, autodisciplinado, sensível, maduro e consistente, e capaz de guardar informações confidenciais.

[...] o observador deve-se preocupar em se fazer aceito, decidindo quão envolvido estará nas atividades e procurando não ser identificado com nenhum grupo particular (LÜDKE e ANDRÉ, 2012, p. 17).

Os pesquisadores que optam pela abordagem qualitativa não se preocupam com representatividade numérica, mas intentam o aprofundamento da compreensão de um grupo social.

Nesse tipo de pesquisa, o pesquisador é ao mesmo tempo sujeito e objeto de sua pesquisa. Como especifica Deslandes (apud Minayo, 1994), o desenvolvimento da pesquisa é imprevisível e o conhecimento do pesquisador é parcial e limitado e tem como objetivo produzir informações acerca de um tema.

Para Minayo (2000), a pesquisa qualitativa trabalha com o universo de significados, motivos, aspirações, crenças, valores e atitudes que correspondem a um espaço mais profundo das relações, dos processos e dos fenômenos que não podem ser reduzidos à operacionalização de variáveis. Ainda para o autor, as características da pesquisa qualitativa são: objetivação do fenômeno, hierarquização das ações de descrever, compreender, explicar, precisão das relações entre o global e o local em um determinado fenômeno, observância das diferenças entre o mundo social e o mundo natural; respeito ao caráter interativo entre os objetivos buscados pelos investigadores, suas orientações teóricas e seus dados empíricos; a 
busca de resultados os mais fidedignos possíveis e oposição ao pressuposto que defende um modelo único de pesquisa para todas as ciências.

Em se tratando de pesquisa em educação, Triviños (1987), critica o procedimento da racionalidade científica, mostrando que ele pressupõe a previsão futura do fenômeno, não considerando o caráter dinâmico e mutável dos fenômenos sociais.

Em referência a pesquisa em educação, André (2000), salienta que numa abordagem qualitativa, a teoria vai sendo construída e reconstruída no processo de pesquisa. A análise ocorre paralelamente à observação, na medida em que o pesquisador seleciona aspectos que devem ser explorados e decide quais os que devem ser abandonados. O autor afirma que a pesquisa na modalidade qualitativa permite apreender o caráter complexo e multidimensional dos fenômenos educacionais, além de captar os diferentes significados das experiências vividas e auxiliar na compreensão das relações entre os indivíduos, seus contextos e ações.

\subsection{Instrumentos de Coleta de Dados}

Como observa Moreira (2002), o pesquisador qualitativo pauta seus estudos na interpretação da interpretação, ou seja, o pesquisador lida com a interpretação de entidades que, por sua vez, interpretam o mundo que nos rodeiam. Como o objeto de estudo das ciências humanas e sociais são as pessoas e suas atividades, os pesquisadores adotam em alguns instrumentos para a coleta de dados. Nesta pesquisa foram utilizados portfólio e o questionário como instrumentos que passamos a discorrer a seguir.

\subsubsection{Portfólio}

O portfólio foi utilizado para organizar as narrativas visuais produzidas pelos alunos. A escolha do procedimento e por entender que está em consonâncias com as mudanças nas concepções de ensino aprendizagem ocorridas nas últimas décadas do século XX.

O portfólio tem sua origem nas artes visuais, como uma "pasta fina e de grande dimensão, onde os artistas e fotógrafos colocavam amostras do seu trabalho, visando uma apreciação por parte de especialistas ou professores". Segundo Villas-Boas (2006 apud Rodrigues, 2009), a primeira utilização do portfólio na educação foi em 1940 no Oltville School no Alabama, como a denominação de folder, onde os trabalhos dos estudantes eram guardados e posteriormente mostrados aos pais. A sua utilização surge novamente nos anos 
1980, como uma forma de organização dos trabalhos tanto no ensino primário, secundário e universitário. Para Bizarro (2001, apud Rodrigues, 2009), “o portfólio é um instrumento de avaliação intrinsecamente adequado às necessidades e às especificidades do seu autor, que reflete o seu processo de aprendizagem e o prepara para a autonomia". Ainda ressalta que se trata de uma construção pessoal, que ganha forma através de uma seleção consciente e organizada dos aspectos a introduzir no portfólio. A configuração que cada indivíduo dá ao seu portfólio, torna-o num trabalho pessoal que reflete as experiências vivenciadas ao longo do seu aprendizado.

Para Tierney et al, (1991, apud Rodrigues, 2009), "o portfólio tem uma dupla funcionalidade, na medida em que pode assumir uma dimensão estruturante e organizadora, como assume uma função reveladora e estimulante nos processos de desenvolvimento pessoal". Acrescenta ainda que a funcionalidade do portfólio nas práticas educativas surge como uma abordagem no campo da educação, o que vem colocar em evidência novas aprendizagens e novas formas de avaliação.

Para Veiga Simão (2004, apud Rodrigues, 2009), “o portfólio como metodologia possibilita um registro contínuo das aprendizagens, dos progressos e das experiências, resultantes do exercício das atividades".

Hernández (1998) define o portfólio como sendo um continente de diferentes classes de documentos (notas pessoais, experiências de aula, trabalhos pontuais, controle de aprendizagem, conexões com outros temas fora da escola, representações visuais, etc.) que proporciona evidências do conhecimento que foi construído, das estratégias utilizadas e da disposição de quem o elabora em continuar aprendendo. Para Veiga Simão (2005, apud Rodrigues, 2009), os portfólios podem dar origem à outra ideia de sala de aula, tornando-o num local onde as aprendizagem se vão construindo em conjunto e individualmente ao ritmo de cada aluno.

Na nossa pesquisa, o portfólio possui um caráter descritivo e reflexivo no qual se trabalhou as narrativas visuais produzidas pelos alunos em suas experiências de vida. Ele foi dividido em três momentos da prática pedagógica. O primeiro momento denominado "Lugares de lembrar a infância", buscou refletir as diferentes formas de se perceber a infância, suas especificidades, suas características, interesses e necessidades, bem como os caminhos percorridos pelos primeiros anos na escola, seus marcos, suas transformações, a partir das seguintes proposições: O que vem à sua mente ao falar de suas lembranças de infância. Onde você nasceu? Quem são seus pais? Qual a história de seu nome? Quem te 
nomeou? Porque este nome? Quais as lembranças de infância que você guardou? O que costumava fazer? Quais as brincadeiras favoritas? Com quem você brincava? Quando foi o seu primeiro dia de aula? Como era a sua professora ou professor? E sua escola? Você lembra quem eram os seus amigos? Como você se divertia? O que gostava de fazer?

No segundo momento nomeado de "Lugares de lembrar a cidade e de sua inserção", foram trabalhadas as vivências fora de casa, com a comunidade: experiência na escola, no trabalho, na igreja e na vizinhança. Quais as dificuldades, contradições, ansiedades e aspirações você evidencia no espaço da cidade?

No terceiro e último momento, "Lugares de sonhar: perspectivas futuras", quais os sonhos, desejos, objetivos e projetos de vida que pretende realizar? A realização dos seus sonhos está alicerçada em quais fatores? O que tenho que fazer para realizar os meus sonhos?

Para a produção das narrativas visuais foram disponibilizados aos alunos diversos materiais, dentre eles o formulário - árvore resultando em várias produções como: desenhos e textos, colagem de gravuras de jornais e revistas.

\subsubsection{Dinâmica da Árvore}

Nessa dinâmica, foi apresentado um desenho de uma árvore em um papel ofício A4, figura 21, no qual os alunos escreveram na copa da árvore um sonho, um desejo, um objetivo ou um projeto de vida que pretende realizar (quais os sonhos, desejos, objetivos e projetos de vida que pretende realizar?). Em seguida, os alunos escreveram ao lado das raízes em que está firmado as suas ações (a realização dos seus sonhos está alicerçado em quais fatores? Em Deus, na família, nos amigos na capacidade individual de realizar as suas ações, na perseverança, autoestima e etc.). No tronco, os alunos escreveram algumas ações para concretizar o que foi sonhado e/ou projetado (o que tenho que fazer para realizar os meus sonhos?).

A dinâmica constituiu a terceira parte do portfólio e resultou em um formulário sobre as perspectivas futuras dos alunos, concluindo a atividade pedagógica com a identificação do passado (infância), presente (cidade) e futuro (perspectivas futuras). 


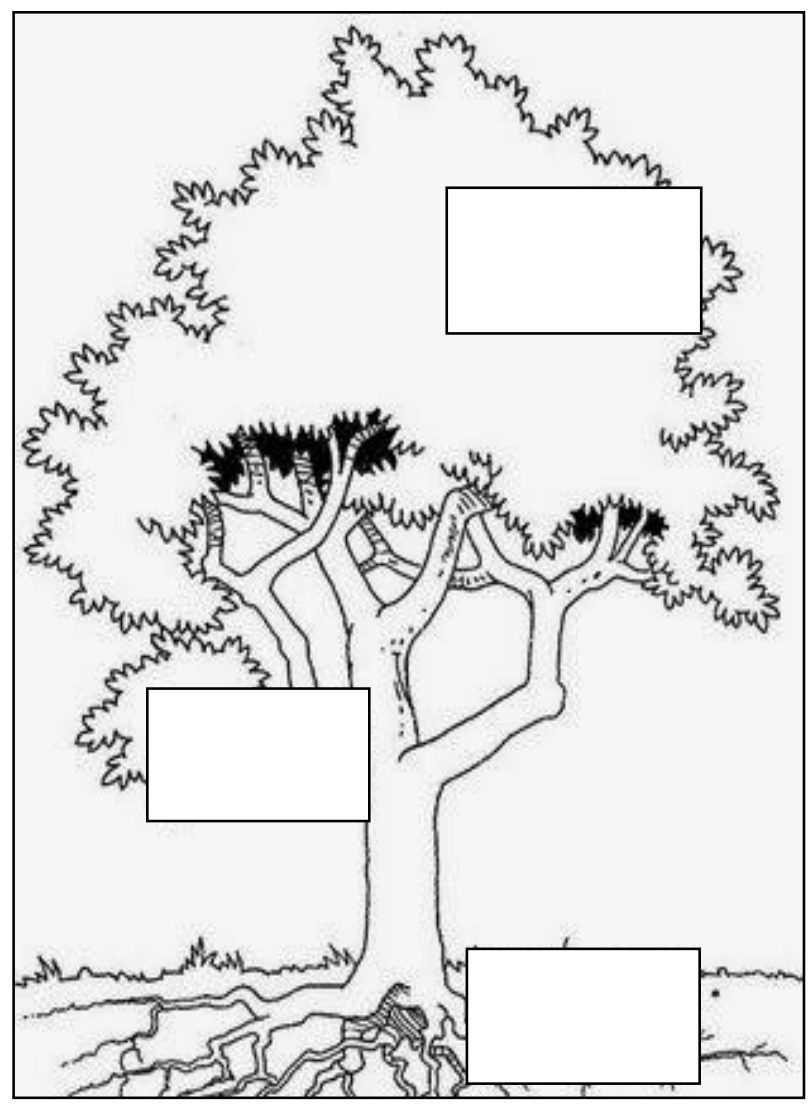

Figura 21. Formulário-Árvore - acervo da autora. BrasíliaDF, 2015.

\subsubsection{Questionário}

A aplicação do questionário foi realizada no primeiro contato da pesquisadora com a turma após a explanação da natureza da pesquisa, sua importância e a necessidade de obter respostas. A intenção era despertar o interesse dos alunos para que eles respondessem o questionário. A partir dele foram gerados dados sobre o perfil dos alunos; a escolaridade da família dos alunos e a formação educacional e profissional dos alunos do CED 01 de Planaltina e do CEM 03 de Ceilândia.

\subsubsection{Perfil dos Alunos}

No CED 01 de Planaltina, o questionário foi aplicado em 28/09/2015 na turma de EJA, do terceiro segmento, do turno noturno. A turma era composta por vinte alunos que responderam a primeira questão sobre a Unidade da Federação de nascimento. O resultado indicou que $60 \%$ dos alunos nasceram no Distrito Federal, seguidos por Goiás 15\%; Minas 
Gerais, São Paulo e Piauí com 5\% em cada Estado. Dos vinte alunos, dois deles não responderam.

No CEM 03 de Ceilândia, o questionário foi aplicado em 07/10/2015, também para uma turma de EJA, terceiro segmento do turno noturno. Dezoito alunos reponderam as trinta e sete questões. A primeira questão sobre a Unidade da Federação de nascimento, os dados indicaram que $67 \%$ dos alunos nasceram no DF; $17 \%$ no PI, 5,6\% nos estados da BA e SP; um aluno não respondeu a questão.

Os dados obtidos nas duas Regiões Administrativas indicaram que a maioria dos alunos de EJA nasceu no Distrito Federal, contrariando o pensamento comum de que os alunos de EJA são migrantes nordestinos de áreas rurais em busca de melhores condições de vida nos espaços urbanos, e sim, jovens que evidenciam as conhecidas deficiências do sistema escolar regular público.

Em relação à idade, em Planaltina $85 \%$ dos alunos têm entre 18 e 22 anos, e apenas três alunos referentes a 15\% da turma, têm 39, 43 e 46 anos. No CEM 03 de Ceilândia os dados são similares ao de Planaltina e apontam o predomínio de jovens entre 18 a 21 anos representando 77,8\% da turma; quatro alunos têm 25, 27, 30 e 44 anos de idade equivalendo a $22,2 \%$ da turma.

Os dados apreendidos nas duas Regiões são indicativos de juvenilização da EJA, processo que começou a ser observado na década de 1990, quando ocorre uma demanda para a modalidade de EJA, até então destinada ao público adulto. Diferentemente do que consta o histórico da EJA no Currículo em Movimento da Educação Básica - Educação de Jovens e Adultos da Secretaria de Estado de Educação do Distrito Federal, que afirma que:

\footnotetext{
A Educação de Jovens e Adultos (EJA) é uma modalidade de educação básica destinada ao atendimento de pessoas jovens, adultas e idosas da classe trabalhadora que, ao longo da sua história, não iniciaram ou mesmo interromperam sua trajetória escolar em algum ou em diferentes momentos de sua vida. (SEEDF, 2014, p. 09).
}

Esse dado (85\%) expressa que a maioria dos alunos não interrompeu a educação básica. Eles saíram do ensino regular diurno em função da distorção idade/série. Segundo Haddad (2000) os dados sobre a defasagem entre idade e série no ensino regular apontam nessa direção. Dados (IBGE, 1997) constatam a existência de 5,3 milhões de pessoas de 15 a 18 anos frequentando a escola em situação de defasagem de ano ou mais. Segundo o autor, a entrada precoce dos adolescentes das camadas mais pobres no mercado de trabalho formal ou informal provocou a sua transferência para os programas de educação destinados à população adulta. 
Quando indagados sobre a categoria de cor ou raça em que estão incluídos, no CED 01 de Planaltina, 55\% dos respondentes se consideram pardos, seguidos de $20 \%$ que se avaliam brancos e amarelos, e apenas 5\% afirma ser da cor preta. Apesar de quatro alunos correspondentes a $20 \%$, responderem que são da raça amarela, não foi identificado na turma nenhum aluno com características orientais ou asiáticas. Da mesma forma, na cor preta, foi observado que o percentual informado é menor do que foi percebido na turma, indicando que não houve compreensão na escala cor ou raça da referida questão.

Já no CEM 03 de Ceilândia, em relação à cor, a maioria se considera parda 55,6\%; na cor ou raça branca $22,2 \%$, igualmente na cor ou raça preta $(22,2 \%)$.

Os dados obtidos nas duas Regiões Administrativas confirmam a análise feita por Florestan Fernandes (1978). Para o sociólogo, os negros saídos de um sistema que por quase quatro séculos sugou-lhes a energia, a moral e a fé em si mesmos se deparam sozinhos, sem garantias sociais, sem um sistema de compensação social e sem apoio institucional na transição para o trabalho livre. Sem as medidas compensatórias, a classe dominante ficou isenta de qualquer responsabilidade com as pessoas que deram o sangue para conferirem riqueza. Os senhores, o Estado e a Igreja deram as costas aos libertos, conferindo-lhes a responsabilidade única sobre suas vidas. Assim, abruptamente, o ex-escravo passou a condição de senhor de si mesmo, tendo que prover seu sustento e de sua família, sem condições materiais.

Ainda, segundo Fernandes (1978), a abolição não conseguiu compensar séculos de exploração, exclusão e indignidade. Os negros e mulatos, sem formas de adentrar no capitalismo emergente, continuaram sendo incorporados à condição de subalterno do sistema político social:

\footnotetext{
A abolição não trouxe um sistema de compensação social. Os negros comemoraram sua liberdade, só mais tarde entendendo que suas condições de vida não teriam mudanças estruturais como sonharam: "sob a aparência da liberdade herdaram a pior servidão, que é a do homem que se considera livre, entregue de mãos atadas à ignorância, à miséria, à degradação social" (FERNANDES, 1978, p.59).
}

A consequência é que o negro se sente diferente. Essa diferença é concretizada em sua desvalorização que é reafirmada nas anedotas, nos provérbios populares, nas propagandas comerciais. Isso deixou marcas traumáticas no povo negro. A religião católica ao justificar a escravidão golpeou o negro em sua dignidade, porque foi rebaixado à condição de um ser não humano. A ciência, com suas teorias sobre raça, no século XIX justificou a escravidão. Todas essas diferenças identitárias foram dadas pelo homem branco, por isso, o negro encontra-se num espaço conflituoso, identificando no silêncio e na negação do racismo e do preconceito 
uma forma de não sofrer para existir. Desta forma, é mais fácil se considerar como pardo do que como negro. Isso fica claro nas respostas dos alunos à questão cor ou raça.

Em relação à situação conjugal, no CED 01 de Planaltina a maioria é solteira correspondendo a $65 \%$, seguido por $20 \%$ em união estável e $5 \%$ casados, $5 \%$ divorciado ou outros 5\%. A grande maioria, $70 \%$, não possuem filhos, $15 \%$ possuem um filho, $10 \%$ possuem dois filhos e apenas $5 \%$ possui quatro filhos. Reposta semelhante dos alunos do CEM 03 de Ceilândia, a maioria 66,7\% é solteira e 77,8\% afirmam não possuir filhos.

No CED 01 de Planaltina, a questão referente a religião ocorre um pequeno diferencial entre o evangélico $44,4 \%$ e católico $33,3 \%$; os alunos que informaram que não possuem religião, corresponde a $16,7 \%$ e os que afirmam ser espírita $(5,6 \%)$. Na questão referente a ser ou não ser praticante, $50 \%$ afirmam que sim; 38,9\% consideram não praticantes. Dois alunos não responderam a questão.

Os dados sobre religião obtidos no CEM 03 de Ceilândia apresentam pouca diferença entre a Católica, 35\%, e a Evangélica, 30\%, em seguida, 25\% que alegam não possuir nenhuma religião; seguidos de outras religiões, $10 \%$, e, apenas $5 \%$ declaram serem adeptos do Espiritismo. 55\% afirmam ser praticantes e $40 \%$ apesar de possuírem religião, não as praticam. Dois alunos não responderam.

As informações obtidas são indicativas do aumento dos números de evangélicos no Distrito Federal, registrado pelo Censo/2010 do IBGE, com uma diminuição de 10 pontos percentuais entre o número de fiéis da Igreja Católica e o aumento de 7,3 no número de evangélicos.

Fato que causou estranhamento, principalmente em Planaltina por possui um complexo religioso como o Vale do Amanhecer, movimento doutrinário e religioso baseado em referências cristãs e espíritas. Seus templos e casas estão espalhados pelos setores da cidade, ao lado do Morro da Capelinha, local que é palco da apresentação teatral ao ar livre, a Paixão e a Morte de Cristo da religião Católica. O espetáculo costuma ser acompanhado por uma multidão de pessoas vindas de várias partes do Brasil e do exterior.

Em termos de moradia, a maioria do CED 01 de Planaltina, 55\% moram com os pais; $20 \%$ assinalaram outra forma de moradia, $15 \%$ vivem com cônjuge ou companheiro e 5\% vivem na casa de família ou hospedaria, 5\% responderam que moram com outras pessoas. Já no CEM 03 de Ceilândia, a maioria dos alunos é 55,6\% mora com os pais. 
Questionados sobre o turno de trabalho, em Planaltina a maioria dos alunos, 60\%, trabalham; 67\% deles em horário integral e os demais em meio período. No CEM 03 de Ceilândia, 55,6\% da turma trabalha oito horas por dia.

Dados do IBGE (2010) apontam que no Brasil o número de jovens vem diminuindo desde a década de 1980; a população entre 15 e 24 anos é de cerca de 34 milhões; embora nasçam mais homens que mulheres, nesta faixa etária estão divididas em partes iguais em razão da maior mortalidade de rapazes vítimas da violência (homicídios e acidentes de trânsito); $81 \%$ vivem em áreas urbanas (27,8 milhões) e apenas $19 \%$ na zona rural. Na cidade, eles estudam e trabalham, estudam e não trabalham ou simplesmente trabalham, já que, para muitos, o trabalho é a possibilidade de experimentar a condição juvenil na esfera de sociabilidade: lazer, cultura, consumo, autonomia, independência e prazer. Muitos destes jovens encurtam sua permanência na escola em função das necessidades econômicas que os empurram para o mercado de trabalho prematuramente.

A figura 22 ilustra os perfis dos alunos do CED 01 de Planaltina e do CEM 03 de Ceilândia.

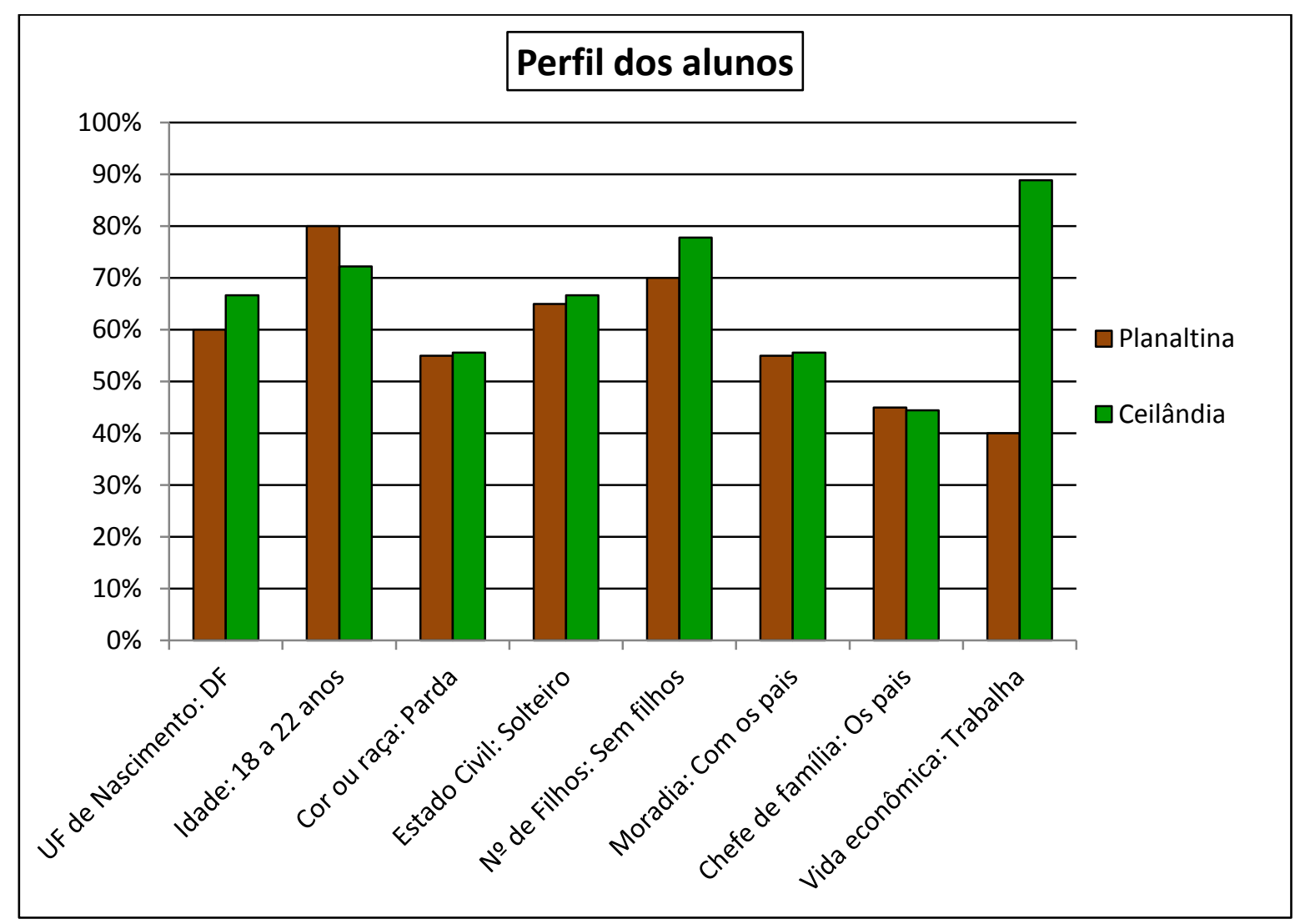

Figura 22. Gráfico - Perfil dos alunos. Brasília-DF, 2016. 


\subsubsection{Escolaridade da Família dos Alunos}

Quando indagados sobre quem é o chefe da família, no CED 01 de Planaltina, 30\% respondem ser o cabeça da família, $25 \%$ a mãe, $20 \%$ o pai e $10 \%$ afirmam ser o cônjuge, o irmão/irmã e outra pessoa, 5\% alegam morar com outra pessoa. No CEM 03 de Ceilândia, a metade das casas é chefiada pela mulher, $50 \%$, demonstrando um aumento na proporção de famílias chefiadas por mulher e comprovada pelos dados do IBGE (1991-2000).

A constatação do aumento do percentual da mãe como chefe de família remete ao conceito de Diane Pearce (1978) sobre a "feminização da pobreza". Ela associa o processo de empobrecimento das mulheres ao aumento na proporção de famílias pobres chefiadas por mulher. Para a autora, essas famílias são aquelas onde há apenas um adulto do sexo feminino e nenhum adulto do sexo masculino. Embora a autora reconheça que há mulheres pobres que vivem em famílias chefiadas por homens que são pobres, ela concentra sua análise nas mulheres que são pobres porque são mulheres.

No CED 01 de Planaltina, sobre a escolaridade do chefe da família, os alunos declaram que a maioria, 35\%, têm o Ensino Médio incompleto; 20\% o Ensino Fundamental incompleto; $15 \%$ possuem o Ensino Médio completo; $10 \%$ o Ensino Superior incompleto; Ensino Fundamental completo, Ensino Superior incompleto e Pós-graduação, e os que não sabem responder têm o mesmo percentual de $5 \%$.

No CEM 03 de Ceilândia, no item sobre a escolaridade do chefe da família predominou o Ensino Médio incompleto com 53,3\%; seguidos de 27,8\% com Ensino Fundamental incompleto. Dados semelhantes foram encontrados em Planaltina.

Em relação à escolaridade do pai, no CED 01 de Planaltina, 50\% dos respondentes afirmam que o pai possui o Ensino Fundamental incompleto; 10\% informam que o pai é analfabeto. Outros responderam que o pai possui o Ensino Fundamental completo, 10\%, o Ensino Superior completo, 10\% e não sabem responder (10\%). Quanto ao Ensino Médio incompleto, $5 \%$, igualmente ao Ensino Médio completo (5\%). No caso da mãe, $50 \%$ possuem o Ensino Fundamental incompleto, seguidos por 20\% com o Ensino Médio completo; $10 \%$ com o Ensino Superior completo equivalente a $10 \%$, e que não sabem responder (10\%). Apenas 5\% informam que a mãe não estudou, possui o Ensino Fundamental completo e o Ensino Superior incompleto.

Observa-se que em Planaltina pais e mães dos alunos têm perfis de escolaridade similares, com 50\% em ambos os grupos com o Ensino Fundamental incompleto, enquanto 
dentre os chefes de família somente $20 \%$ estão nesta categoria. Isto mostra que o chefe da família é mais escolarizado que a mãe e o pai indicando que, na maioria dos casos, a função do chefe da família é exercida pelo mais escolarizado.

Já no CEM 03 de Ceilândia, sobre o grau de instrução do pai, 50\% possuem o Ensino Fundamental incompleto; de dezoito alunos que responderam o questionário dois alunos afirmaram que os pais não estudaram, dois informaram que desconhecem a escolaridade. $\mathrm{O}$ grau de instrução das mães apresentam níveis similares ao do pai, 50\% possuem o Ensino Fundamental incompleto, conforme se vê na figura 23.

Os dados obtidos nas duas Regiões Administrativas remetem ao abandono da escola antes de completar o ensino fundamental ou médio, fenômeno observado por Gentili (2001) ao discutir os efeitos da hegemonia neoliberal que transforma tudo em mercadoria, inclusive a educação que passa de direito à mercadoria, aumentando os processos de exclusão. Por outro lado, o aluno impelido para o mercado de trabalho desde cedo encontra vários empecilhos para continuar os estudos como: cansaço decorrente de longa jornada de trabalho, o desemprego, a falta de autoestima que diante das dificuldades financeiras deixa a escola. Além disso, pais analfabetos e desestimulados não encontram perspectivas em mandar seus filhos à escola. Geralmente, os pais têm ou tiveram uma escolarização inferior aos filhos.

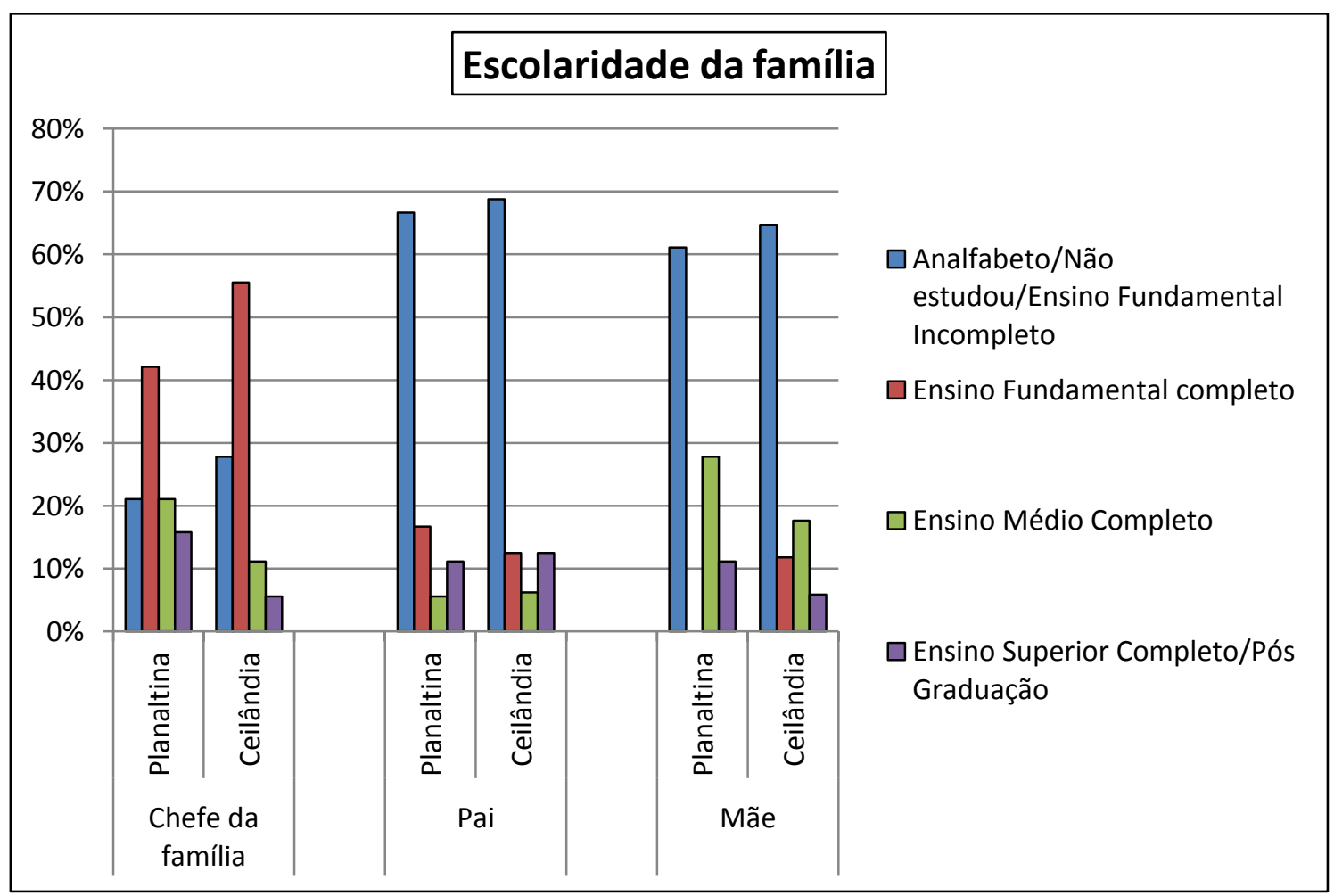

Figura 23. Gráfico - Escolaridade da família. Brasília-DF, 2016. 
Sobre a participação do aluno na vida econômica da família no CED 01 de Planaltina, $40 \%$ trabalham e contribuem para o sustento da família; 35\% não trabalham, e são sustentados por outras pessoas; $15 \%$ trabalham e são responsáveis pelo seus sustentos e apenas $10 \%$ trabalham e são os principais responsáveis pelo sustento da família. No CEM 03 de Ceilândia, $33,3 \%$ alegam que trabalham e são responsáveis pelo o próprio sustento e contribuem com o sustento da família.

\subsubsection{Formação Educacional e Profissional dos Alunos}

No CED 01 de Planaltina, em relação ao tipo de escola que frequentou durante toda a vida, $70 \%$ afirmam que sua educação foi realizada, exclusivamente, na escola pública. 25\%, a maior parte da formação na escola pública, e 5\% cursaram na escola particular. Dados similares foram encontrados no CEM 03 de Ceilândia, onde 77,8\% afirmam que toda a educação foi realizada na escola pública.

Arroyo (2006) assinala que, geralmente, os alunos de EJA são pessoas com baixo poder aquisitivo, que consomem, de modo geral, apenas o básico à sua sobrevivência. O lazer fica por conta dos encontros com as famílias ou dos eventos da comunidade.

Para Arroyo (2006), o objetivo da volta à escola, geralmente é para continuar os estudos, satisfação pessoal, conquista de um direito, sensação de capacidades e dignidade ou simplesmente, um diploma, e finalmente, o mais comum, conseguir um trabalho melhor e mudar sua situação econômica.

Acerca do grau de expectativa em relação ao término do Ensino Médio, no CED 01 de Planaltina, 55\% afirmam ter altíssima expectativa, 35\% terem alta expectativa, enquanto $10 \%$ afirmam ter baixa expectativa. Indagados sobre o que pretende fazer após o término do Ensino Médio, $40 \%$ pretendem continuar estudando e trabalhando; $30 \%$ apenas continuar estudando; $25 \%$ só trabalhando e $5 \%$ não têm a menor ideia. Dos que afirmam que pretendem continuar trabalhando, 55\% vão trabalhar onde for possível e $45 \%$ exclusivamente na área de seus interesses. Aqueles que optam por continuar estudando pretendem ingressar em uma Universidade (45\%). Os que optam por cursos profissionais de nível médio, representam 25\%; o curso de Pós-Graduação Strictu Sensu ficam com 15\% e Especialização em PósGraduação com $10 \%$.

No CEM 03 de Ceilândia, sobre o grau de expectativa em relação ao término do Ensino Médio, 33,3\% informam ter alta expectativa, seguidos por 27,8\% manifestaram serem 
indiferentes e três alunos não responderam. A metade dos alunos, 50\%, pretende continuar estudando, seguidos de 27,8\% que querem trabalhar e estudar simultaneamente. Quando questionados sobre trabalho, os alunos responderam que $61,1 \%$ desejam trabalhar na área de interesse, seguidos por trabalhar onde for possível $(33,3 \%)$.

Em relação à expectativa acadêmica, 50\% responderam que pretendem ingressar na universidade, seguidos de 16,7\% que desejam cursar a Educação Profissional de nível médio.

A partir dos dados é possível afirmar que a mobilidade social é o que move o término do Ensino Médio e a entrada em uma faculdade. Eles acreditam que a educação pode propiciar um trabalho melhor ou a profissão sonhada.

Os alunos do CED 01 de Planaltina, quando indagados sobre a principal fonte de informação, $80 \%$ mencionaram o acesso a internet com principal fonte; 30\% programas de TV; $10 \%$ jornal impresso e outros; apenas $5 \%$ afirmam ter o Rádio como fonte de informação. Questionados sobre a frequência de busca da informação, 50\% afirmam que diariamente, 20\% semanalmente e ocasionalmente. Dois alunos não responderam. No CEM 03 de Ceilândia, 83,3\% buscam diariamente informação na internet. Acerca do tipo de leitura preferida dentre as opções oferecidas no questionário, $44,4 \%$ dos respondentes optam por outro tipo de leitura, enquanto 77,8\% afirmam ler de 1 a 3 livros por ano.

Até a década de 1990, a televisão era o principal canal de lazer e informação, atualmente ela foi superada pelas tecnologias de informação e comunicação - TIC, constituindo-se a internet a principal fonte de informação e lazer.

Perguntados sobre preferências de leitura 30\% respondem que outros tipos leitura em relação às opções da questão; $15 \%$ informam que não leram nenhum livro, $15 \%$ indicam que gostam de livros de esporte e lazer, autoajuda e religião; $10 \%$ gostam de literatura nacional e $5 \%$ de política e literatura estrangeira. Dois alunos não responderam. Para os que gostam de ler, $45 \%$ afirmam ler cerca de 1 a 3 livros por ano; $35 \%$ afirmam ler de 4 a 7 livros por ano e $5 \%$ informaram ler de 8 a 12 livros por ano e três alunos não responderam (15\%).

Procurando identificar se os alunos do CED 01 de Planaltina tem domínio da tecnologia de informação e comunicação, $45 \%$ afirmam que têm experiência com o microcomputador; $35 \%$ têm alguma noção, seguidos de $15 \%$ que afirmam possuir muita experiência e um aluno não respondeu. No CEM 03 de Ceilândia, os dados apontam que $38,9 \%$ têm alguma noção no manuseio de microcomputadores. Estes dados indicam que os alunos de EJA entenderam que o domínio dos meios digitais é fundamental para garantir uma melhor inserção no mundo do trabalho e da informação. 
A formação educacional e profissional dos alunos do CED 01 de Planaltina e do CEM 03 de Ceilândia estão sintetizadas no gráfico da figura 24.

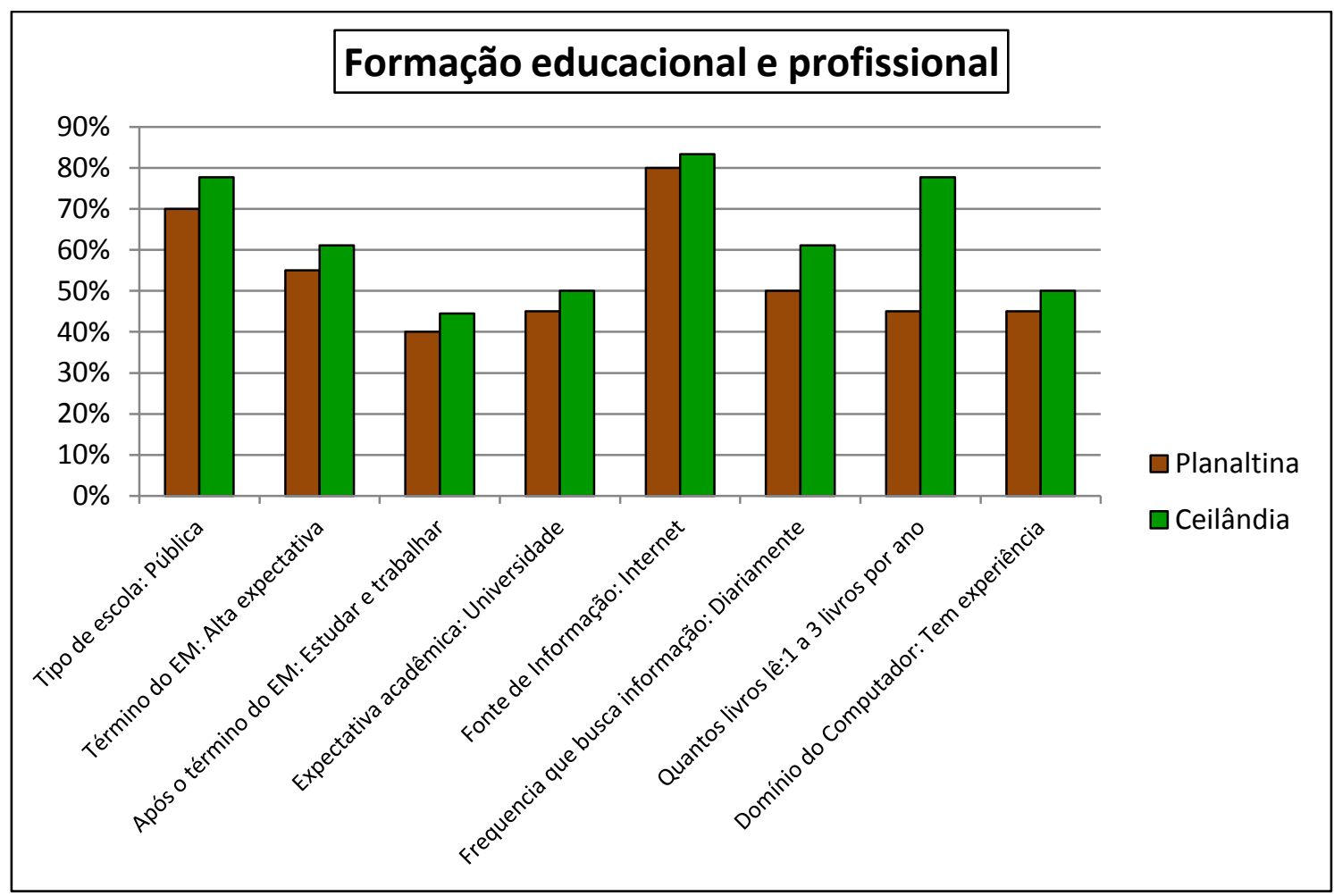

Figura 24. Gráfico - Formação Educacional e Profissional. Brasília-DF, 2016.

Quando questionados sobre o atendimento médico/hospitalar, os alunos do CED 01 de Planaltina afirmaram quem tem acesso aos serviços básicos de saúde. $85 \%$ procuram a rede pública de saúde e $15 \%$ a rede particular. $55 \%$ afirmam ter realizado consulta de rotina no último ano; $20 \%$ consultaram o médico entre 1 a 5 anos e $10 \%$ dos alunos afirma que mais de 5 anos. Um aluno não respondeu. Ao questionar sobre doenças crônicas todos os alunos responderam não possuir nenhuma doença. Já no CEM 03 de Ceilândia, 83,4\% procuram atendimento médico na rede pública de saúde; 55,6\% utilizam de consulta de rotina anual, seguidos por $27,8 \%$ que não lembram quando foi a uma consulta médica, 94,4\% afirmam que não possuem nenhuma doença crônica.

Desejando saber se a turma de Educação de Jovens e Adultos do CED 01 de Planaltina, conta com alunos com necessidades educativas especiais, perguntou-se: "Você é portador de necessidade especial/deficiência?" 80\% afirmam que não; $10 \%$ afirmam possuir alta habilidade; 5\% necessidade visual e outras. No CEM 03 de Ceilândia, 66,7\% informam não possuir nenhuma deficiência, 16,7\% afirmam possuir problema visual e 11,1\% alegam possuir alta habilidade. 
Querendo saber sobre a saúde bucal dos alunos do CED 01 de Planaltina, 40\% alegam que só vão ao dentista em caso de dor; $30 \%$ rotineiramente; $20 \%$ nunca foram ou não se lembram; 5\% a cada 6 meses ou 1 ano e esporadicamente. No CEM 03 de Ceilândia, 33,3\% afirmam que só procuram o dentista em caso de dor.

Para avaliar a saúde mental dos alunos do CED 01 de Planaltina foi perguntado se o aluno teve alguma dificuldade ou crise emocional no último ano. 65\% afirmam que não; 30\% respondem que sim e um aluno não respondeu. Quando indagados se já procuraram algum atendimento psiquiátrico em algum período da vida, $70 \%$ afirmam que não, $25 \%$ respondem que sim e um aluno não respondeu. No CEM 03 de Ceilândia, 66,7\% alegam não ter tido nenhuma crise emocional no último ano e, 93,3\% declaram que nunca foi à consulta com um psiquiatra.

Na convivência com as turmas de EJA do CED 01 de Planaltina e do CEM 03 de Ceilândia foi possível constatar a juvenilização dos alunos, dado corroborado por Ribeiro (2015) ao afirmar que ela foi intensificada tanto no Brasil como nos países da América Latina em virtude das deficiências do sistema escolar. A prática da repetência estabelecida e sucessivamente promovida por esses sistemas escolares são na verdade uma das razões que ocasionam a defasagem entre idade e série. Assim, a Educação de Jovens e Adultos necessita ser repensada considerando as características dessa clientela: mais jovem e urbana, em busca de certificações da Educação Básica e de melhores condições de vida. 


\section{REFERENCIAL TEÓRICO DA PESQUISA}

\subsection{Contribuições das Teorias acerca do Conhecimento}

Como ocorre a construção do conhecimento humano?

Para responder a pergunta foram desenvolvidas várias teorias. Dentre elas a de Lev Semenovich Vigotsky que enfatiza o caráter transformador da atividade humana. Em sua visão o sujeito é herdeiro da evolução filogênica e cultural e o seu desenvolvimento ocorre na relação homem-mundo.

Por essa concepção, na interação com os outros o indivíduo elabora seus conhecimentos. Dessa forma o conhecimento tem sua gênese nas relações sociais, sendo produzido na intersubjetividade e marcado por condições culturais, sociais e históricas.

Para Vigotsky (1984), o homem produz seus conhecimentos por meio da linguagem nas inter-relações com outros sujeitos e pela apropriação do saber da comunidade em que o indivíduo vive. Assim, são construídos instrumentos e signos linguísticos como elementos facilitadores da relação entre o homem e mundo.

Os instrumentos foram criados pelo homem para exercer a sua atividade, servem de mediadores com o meio. Os instrumentos potencializam o corpo e a mente humana. Externamente, a atividade do homem é mediada por instrumentos técnicos que favorecem e ampliam as suas ações sobre os objetos. Quando a sua mão não alcança o alvo que deseja, o homem procura ou constrói um objeto que favoreça a sua ação. $\mathrm{O}$ uso desses recursos pode não advir simplesmente da presença deles no seu campo perceptual, mas de sua capacidade inventiva e criadora em busca de resolução de um problema. O homem, por desenvolver imagens mentais, conserva em sua experiência e guarda o instrumento, passando a usá-lo como mediador em outras situações.

Nesta perspectiva, o trabalho humano une a natureza ao homem e cria a cultura e a história do homem, desenvolve a atividade coletiva, as relações sociais e a utilização de instrumentos. Os instrumentos são utilizados pelo trabalhador, ampliando as possibilidades de transformar a natureza, sendo assim, um objeto social.

Segundo Vigotsky (1984) o mesmo ocorre com a utilização de instrumentos psicológicos - os signos linguísticos que serve de mediadores para a interação sócio afetiva e cognitiva dos indivíduos, desenvolve suas funções psicológicas superiores, aquelas ligadas à consciência, que marcam o seu desenvolvimento como pessoa - sua ontogênese. A atividade 
humana regulada pelos instrumentos psicológicos dá origem ao pensamento e permite ao indivíduo controlar o seu próprio comportamento, as suas ações sobre os outros homens. O que permite ao ser humano conservar, registrar e transmitir suas experiências favorecendo a continuidade de sua história.

A capacidade humana para a linguagem faz com que o homem crie os signos, meios que auxiliam a função psicológica superior e permitem ao homem realizar operações cada vez mais complexas sobre os objetos. Segundo Vigotsky, com o uso dos signos ocorrem duas mudanças qualitativas no pensamento humano: o processo de internalização e a utilização de sistemas simbólicos. A internalização está relacionada ao recurso da repetição onde o indivíduo apropria-se da fala do outro, tornando-a sua. Já os sistemas simbólicos organizam os signos em estruturas complexas e articuladas. Essas duas mudanças demonstram a importância das relações sociais na construção de processos psicológicos e no desenvolvimento dos processos mentais superiores. Os signos são internalizados e compartilhados pelo grupo social, permitindo o aprimoramento da interação social e a comunicação entre os sujeitos.

Nesta perspectiva, todas as funções psicológicas superiores, aquelas ligadas à consciência, como estabelecer relações, planejar, comparar e lembrar supõem um processo de representação mental. Entretanto, lidar com essa representação significa possibilitar ao homem libertar-se do espaço presente, em estabelecer relações mentais na ausência das próprias coisas, imaginar, planejar, ter intenções. Assim, quando se trabalha os processos mentais superiores que se distinguem do funcionamento psicológico típico dos seres humanos, as representações mentais da realidade exterior são na verdade os principais mediadores a serem considerados na relação homem-mundo.

As funções psicológicas superiores aparecem duas vezes no desenvolvimento do indivíduo. A primeira vez, no nível social, entre as pessoas - nível interpsicológico. A segunda vez, no nível individual, no interior do indivíduo - nível intrapsicológico. É a partir da internalização da cultura mediada por outro individuo, que o sujeito se constitui como singular. Vigotsky (1998) assinala que tudo o que constitui o sujeito já esteve antes no âmbito social, isto quer dizer que antes de fazer parte do intrassubjetivo, os processos psicológicos fizeram parte da intersubjetividade. Esse movimento ocorre pela internalização, que possibilita ao sujeito se apropriar do que existe no externo por meio da mediação de signos apropriados na relação com outros, para torná-la interna. Assim, o sujeito constrói a si e aos outros. 
Como o desenvolvimento ocorre do nível social para o individual, exige-se a utilização de instrumentos para transformar a natureza e, a forma, o planejamento, a ação coletiva, a comunicação social. Pensamento e linguagem associam-se devido à necessidade de intercâmbio durante a realização do trabalho. Assim, o grupo cultural fornece ao indivíduo um ambiente estruturado onde os elementos são carregados de significado cultural. Visto que os significados das palavras fornecem a mediação simbólica entre o indivíduo e o mundo. Para Vigotsky, é no significado da palavra que a fala e o pensamento se unem em pensamento verbal. Pensamento e linguagem iniciam-se pela fala social passando pela fala egocêntrica e atingindo a fala interior que é o pensamento reflexivo.

Nessa linha de pensamento, a fala egocêntrica da criança é a interiorização de uma linguagem social que ocorre inicialmente como uma forma de regulação do comportamento do outro. À medida que a criança se desenvolve, a fala egocêntrica expressa e permite uma auto regulação, o controle e o planejamento do próprio comportamento, ou seja, a fala egocêntrica assinala a passagem de uma linguagem social externa para uma linguagem individual interna (pensamento).

A fala egocêntrica emerge quando a criança transfere formas sociais e cooperativas de comportamento para a esfera das funções psíquicas interiores e pessoais. No início do desenvolvimento, a fala do outro dirige a ação e a atenção da criança, que se utiliza dela de forma a afetar a ação do outro. Durante esse processo, a criança passa a entender a fala do outro e a usar essa fala para regulação do outro. Ela começa a falar para si mesma, assumindo a função autorreguladora, e é assim que o indivíduo torna-se capaz de atuar sobre suas próprias ações por meio da fala.

O surgimento da fala egocêntrica indica a trajetória da criança, na qual o pensamento parte dos processos socializados para os processos internos. A fala interior ou discurso interior é a forma de linguagem interna, que é dirigida ao sujeito e não a um interlocutor externo. Essa fala interior se desenvolve mediante um lento acúmulo de mudanças estruturais, fazendo com que as estruturas de fala que a criança já domina, tornem-se estruturas básicas de seu próprio pensamento. A fala interior não tem a finalidade de comunicação com outros, portanto, constitui-se como uma espécie de dialeto pessoal, sendo fragmentada, abreviada.

Enfim, no convívio social, a experiência interpessoal possibilita o processo de elaboração e reelaboração de sentidos que organizam e integram a atividade psíquica dos participantes da relação. Este movimento relacional cria múltiplas possibilidades de significação, construídas no momento da relação, a partir de uma dinâmica complexa entre o 
pessoal e o social, que só pode ser compreendida no contexto de mútuas e contínuas influências, fazendo aparecer novas reorganizações que surgem em cada experiência intersubjetiva.

O meio como fonte de conhecimento, na perspectiva histórico-cultural é construído a partir da atividade relacional dos indivíduos com os elementos naturais e sociais que o constituem. Esse meio é natural e social e resultado das relações culturais. Essa noção de cultura, integrante do processo de construção de conhecimento, é a concepção central para a aprendizagem, e está incorporada na experiência dos indivíduos.

\subsection{Aproximações Epistemológicas de Freire e Vigostky}

As ideias de Vigotsky foram gestadas na Rússia pós Revolução Bolchevista ${ }^{23}$; entretanto, aqui no Brasil, em meados do século XX, surge o pensador Paulo Freire que tem em comum com Vigotsky a ideia da educação como uma prática ética, política e social. Ambos teóricos, mesmo vivendo e produzindo em épocas diferentes e realidades diversas, possuem preocupações semelhantes sobre os problemas educativos dos dois continentes.

A primeira aproximação entre os dois pensadores está na base epistemológica. Tanto Paulo Freire como Vigotsky utilizam alguns conceitos do marxismo para a fundamentação de sua teoria. Vigotsky se apropria do marxismo quando ressalta o papel dos instrumentos para a transformação da natureza, para então elaborar a noção de signo e sua função na transformação do psiquismo humano. O materialismo dialético e histórico é utilizado para a compreensão do contexto e as ações do sujeito, entendendo o fenômeno psicológico como algo vivo, em constante movimento (Petrônia e Souza, 2009). Os conceitos de práxis, de luta de classe e alienação de Marx contribuem para a formulação da proposta de Paulo Freire (Santos, 2000).

Os dois pensadores entendem o sujeito como um ser histórico-cultural. Para Vigotsky, o homem só se constitui mediado pela história porque, ao longo de seu desenvolvimento, sofre influência da cultura e da história na qual está inserido. Já para Paulo Freire, o homem se encontra inserido em uma realidade social que deve ser utilizada como ponto de partida para a sua compreensão (Santos, 2000). O homem deve ser compreendido em sua totalidade e não como um sujeito isolado, em que pensar e agir criticamente a realidade na busca de

\footnotetext{
23 A Revolução Bolchevique de 1917 foi resultado de uma série de eventos políticos na Rússia, como a eliminação da autocracia russa, a instalação do Governo Provisório e o estabelecimento do poder do partido bolchevique. O resultado do processo foi a criação da União Soviética que durou até 1991.
} 
transformá-la, faz parte da sua natureza, no caminho de sua humanização (Paulo Freire, 1999).

Tanto Paulo Freire, quanto Vigotsky defendem que na interação e nas relações sociais os sujeitos se constituem e produzem conhecimento (Santos, 2000). Outro ponto de intersecção entre os dois pensadores é a importância dada ao diálogo por Paulo Freire e à Linguagem por Vigotsky.

Para Vigotsky (1998), a linguagem influencia o desenvolvimento do pensamento, e é por meio dela que o indivíduo transforma o concreto em abstrato, passa do âmbito do real para o simbólico, permitindo que o sujeito formule representações. A linguagem é constituída socialmente, por isso carrega tudo o que há de produção na sociedade.

Em Paulo Freire (1996, 1999), o diálogo é a fonte de comunicação entre os sujeitos, o que permite que se aproximem e expressem suas opiniões, estabelecem uma relação bidirecional, em que ambos possam aprender e ensinar, promovendo o desenvolvimento da consciência crítica.

Os dois pensadores afirmam que o conhecimento se constrói a partir da experiência. Freire (1996) afirma que o conhecimento deve ser construído partindo-se da necessidade reconhecida no cotidiano do sujeito. Para Marques e Oliveira (2005, p.5), “conhecer, na teoria freireana, é uma aventura pessoal num contexto social". Em Vigotsky, o conhecimento ocorre a partir do que é sabido pelo indivíduo de seu cotidiano, do que ele internalizou ao longo de seu desenvolvimento, por meio das relações sociais estabelecidas, como produção cultural (Vigotsky, 1998).

Outro ponto no qual as ideias dos dois pensadores se assemelham, é em relação aos métodos de ensino que consideram inadequados. Ambos apresentam críticas à educação como simples transmissão de conhecimento, ao modo de ver o sujeito como individual, a-histórico, como se o seu saber não sofresse influência da cultura e o indivíduo não estivesse inserido em uma sociedade.

Moura (1998), assinala que tanto Paulo Freire como Vigotsky preocupavam-se com os problemas que afetavam a sociedade como a fome, a miséria, as injustiças, a opressão, ou seja, todas as formas de exclusão social, principalmente o analfabetismo; considerado como uma forma de "castração" dos sujeitos (Paulo Freire) e uma "interrupção no processo de desenvolvimento" (Vigotsky), constituindo-se como resultado de uma sociedade desigual e injusta. Ambos buscam a gênese histórica do analfabetismo e as suas consequências na vida dos sujeitos, procurando analisar as causas político-pedagógico para o fracasso escolar das 
crianças, traduzido na repetência, na exclusão e na expulsão precoce, que resulta no analfabetismo adulto.

Para Moura (1998), os dois entendem que a educação não é um ato de memorização mecânica desvinculada de um universo existencial. Ambos atribuem à linguagem um papel preponderante na vida dos sujeitos. Também atribuem à palavra um estatuto central de seus estudos e pesquisas. A palavra, como o signo responsável pelo desenvolvimento cultural dos sujeitos, já que ela é o signo cultural de mediação, responsável pela transformação das funções naturais de inteligência do sujeito para as funções superiores ou culturais. Em Paulo Freire, a palavra possui duas dimensões: ação e reflexão, que são unificadas na práxis. A palavra é a mediadora do homem com o mundo e tem a função de transformar o mundo.

Ainda para Moura (1998), tanto em Paulo Freire quanto em Vigotsky, a leitura e a escrita ao serem "interpretadas", "construídas" e "internalizadas" pelos sujeitos, não só se consolidam como um ato cognoscente, mas também, engendram outros processos cognoscentes e interventivos. Para os dois, a "apropriação" da linguagem escrita é o resultado da relação entre o desenvolvimento da linguagem verbal, do pensamento e da representação da realidade. Para a autora, em Vigotsky essa representação se faz a princípio, em forma de "rascunho mental", por meio do pensamento, da linguagem interior, para chegar ao processo de ensino-aprendizagem, à produção da linguagem enquanto um sistema de comunicação real.

Outro ponto de convergência entre Paulo Freire e Vigotsky, são as influências socioculturais sobre as capacidades cognitivas dos sujeitos. Paulo Freire afirma que a aprendizagem ocorre nas relações entre os seres humanos num espaço que não é apenas físico, mas histórico e cultural. Vigotsky assegura que o desenvolvimento das funções superiores ou da inteligência cultural do homem não é tão somente uma evolução fisiológica e biológica, mas histórica e cultural. Ambos entendem o homem como ser portador e produtor de cultura, um ser de relações socioculturais possibilitadas pelo trabalho, pela ação e transformação da natureza.

Eles dão ênfase ao diálogo como estruturante das relações sociais. Em Paulo Freire e Vigotsky a relação sujeito-sujeito e sujeito-mundo são indissociáveis. Isso fica claro na fala de Paulo Freire (1992, p. 68) quando ressalta que, "Ninguém educa ninguém, ninguém educa a si mesmo, os homens se educam entre si, mediatizados pelo mundo".

Os dois entendem que os conteúdos da experiência histórica do homem não estão consolidados somente nas coisas materiais, mas principalmente, nas formas verbais de comunicação produzidas entre os homens. É por meio da linguagem que se dá a interiorização 
dos conteúdos, pois ela faz com que a natureza social das pessoas se torne também sua natureza psicológica.

O termo experiência tem sido empregado para nomear diversas situações, como por exemplo, no sentido filosófico, no qual a apreensão de uma realidade por parte de um sujeito, uma forma de ser, um modo de fazer, uma maneira de viver, ou seja, a experiência, é um modo de conhecer algo imediatamente antes de todo juízo formulado acerca do apreendido; também pode ser a apreensão sensível da realidade externa, sendo essa realidade dada por intermédio da experiência.

Para a psicologia e a psicanálise, a experiência é aquisição prática, pelo indivíduo, dos conhecimentos que o contato direto com os eventos físicos ou mentais lhe proporciona. As duas áreas do conhecimento tem em comum a ideia de que a experiência remete àquilo que foi aprendido, experimentado e que em algum momento foi vivido pelo indivíduo na sua história de vida ${ }^{24}$.

Essa mesma ideia encontra-se em Vigotsky ao explicar que a imaginação nutre-se de materiais tomados da experiência vivida pelo indivíduo. Quanto mais rica for a experiência humana, tanto maior será o material colocado à disposição da imaginação, ou seja, a capacidade criadora está relacionada à ampliação da experiência cultural do sujeito.

\subsection{Experiência e Narrativa}

Em Walter Benjamim (1994), a narrativa é a expressão da experiência: “o narrador retira da experiência o que ele conta: sua própria experiência ou a relatada pelos outros" ( $p$. 201). Por apresentar características de oralidade, a narrativa mantém as tradições e as conserva diferentemente do romance que trata do sentido da vida, encerrando sempre a história com um final que é imposto ao leitor. Assim, para Benjamin (1994), a narrativa seria a forma de comunicação mais adequada ao ser humano já que reflete a experiência humana.

Narrar alguma coisa consiste, segundo Benjamin (1984), na "faculdade de intercambiar experiência” (p. 213), uma vez que ela reconstrói à medida que é narrada. Em seu texto sobre "O Narrador", o autor afirma que "a narrativa contempla a experiência contada pelo narrador e ouvida pelo ouvinte, que por sua vez, ao contar aquilo que ouviu, transforma-se ele mesmo em narrador por já ter amalgamado à sua experiência a história ouvida".

\footnotetext{
${ }^{24}$ Ver Cabral, Álvaro. Dicionário de Psicologia e Psicanálise, Rio de Janeiro: Expressão e Cultura, 1979.
} 
A união entre experiência e narrativa como expressão, tem sido bastante utilizada como técnica metodológica de pesquisa nos meios acadêmicos. Pela narrativa é possível se aproximar da experiência, tal como ela é vivida pelo narrador.

Essa é a concepção de Clandinin e Connnely (2011) ao desenvolver estudos que têm como foco a compreensão de como os indivíduos ensinam e aprendem. O objetivo dos autores é identificar como a temporalidade se conecta com as transformações e a aprendizagem. Como pesquisadores narrativos, defendem que o objeto de estudo é a própria educação como forma de experiência que acontece narrativamente. Os autores partem da compreensão de experiência como histórias vividas e narradas, sendo a pesquisa narrativa o método utilizado para compreender e interpretar as dimensões pessoais e humanas para além de esquemas fechados, recortados e quantificáveis. Segundo os autores, a narrativa pode ser um instrumento de pesquisa, mas também um método, já que possibilita ao pesquisador apreender a experiência humana. Para os autores a investigação narrativa:

É uma forma de compreender a experiência. É um tipo de colaboração entre pesquisador e participante, ao longo de um tempo, em um lugar ou série de lugares, e em interação com milieus. Um pesquisador entra nessa matriz no durante e progride no mesmo espírito, concluindo a pesquisa ainda no meio do viver e do contar, do reviver e recontar, as histórias de experiências que compuseram as vidas das pessoas, em ambas perspectivas: individual e social (CLANDININ e CONNELLY, 2011, p. 51).

Nessa perspectiva, os autores entendem a pesquisa narrativa como alternativa para a compreensão das histórias vividas e narradas como possibilidade de interpretar as dimensões pessoais e humanas além de esquemas fechados, recortados e quantificáveis.

Esse também é o entendimento construído por Josso (2010) ao propor um trabalho de pesquisa a partir da narração das histórias de vida. Entretanto, esta narrativa proposta por Christine Josso é uma reflexão de si mesmo: as heranças, continuidades, rupturas, projetos de vida, aquisições de experiência, dentre outros que permitem perceber as mutações sociais e culturais na vida singular e sua relação como os contextos da vida escolar e social.

$\mathrm{Na}$ verdade, a abordagem autobiográfica é um processo de investigação dos diferentes momentos de si mesmo, configura-se por vincular a produção de conhecimentos dos sujeitos adultos. Levando-os a tomar consciência de si e de suas aprendizagens experienciais, vivendo o papel de ator e investigador da sua própria história.

Para Josso (2007), nessa autobiografia o sujeito se desloca numa análise entre o papel vivido de ator e autor de suas próprias experiências, que se intercruzam com as histórias coletivas e permitem as pessoas compreenderem a sua vida cotidiana, suas dificuldades e 
contrações, as tensões e problemas que esta lhes impõe ao mesmo tempo traduz as estruturas micro sociais. Segundo a autora:

Falar de recordações-referências é dizer, de imediato, que elas são simbólicas do que o autor compreende como elementos constitutivos da sua formação. A recordaçãoreferência significa, ao mesmo tempo, uma dimensão concreta ou visível, que apela para as nossas percepções ou para as imagens sociais, e uma dimensão invisível, que apela para emoções, sentimentos, sentidos e valores. [...] São as experiências que podemos utilizar como ilustração numa história para descrever uma transformação, um estado de coisas, um complexo afetivo, uma ideia, como também uma situação, um acontecimento, uma atividade ou um encontro. E essa história me apresenta ao outro em formas sócio-culturais, em representações, conhecimentos e valorizações, que são diferentes formas de falar de mim, das minhas identidades e da minha subjetividade. Assim, a construção da narrativa de formação de cada individuo conduz a uma reflexão antropológica, ontológica e axiológica. (JOSSO, 2004, p. 4041).

Para a autora, as recordações e as referências constitutivas da formação quando narradas e centradas na análise e interpretação das histórias de vidas escritas, permitem colocar em evidência a pluralidade, a fragilidade e a mobilidade de nossas identidades ao longo da vida.

Cunha (1997) defende as narrativas como produtoras de conhecimentos que, ao mesmo tempo em de fazem veículos, constroem os condutores, visto que ao narrar, o ser humano simultaneamente produz e compartilha novos conhecimentos com seus interlocutores. Ao falar e escrever sobre si, o narrador estabelece uma forma de comunicação que transita entre dois mundos inseparáveis: o individual e o coletivo, pois a dualidade "eu" e “outro" está impressa tanto no contador de histórias, quanto no ouvinte das histórias.

A palavra narrativa do étimo latino narrare significa relatar, contar uma história, combinar histórias de vida a contextos sócios históricos. Ao mesmo tempo em que as narrativas revelam experiências individuais, elas podem lançar luz sobre as identidades dos indivíduos e as imagens que eles têm de si mesmo. Elas também são constitutivas de fenômenos sócios históricos específicos nos quais as biografias se enraízam.

Como observam Bauer e Gaskell (2002), o objetivo das narrativas não é apenas reconstruir a história de vida do informante, mas compreender os contextos em que essas biografias foram construídas e os fatores que produzem mudanças e motivam ações. Os autores advertem que nas entrevistas narrativas a memória é seletiva, onde nem todos os eventos são lembrados, alguns são esquecidos deliberada ou inconscientemente. Neste sentido, o importante é o que a pessoa registrou de sua história, o que experimentou o que é real para ela e não os fatos em si. Para os autores as narrativas são representações ou interpretações do mundo e, por isso não estão abertas a comprovação e não podem ser 
julgadas como verdadeiras ou falsas, pois expressam a verdade de um ponto de vista em determinado tempo e espaço, em um contexto sócio e histórico. Não se tem acesso direto às experiências dos outros, se lida com representações dessas experiências ao interpretá-las a partir da interação estabelecida.

Para Martins e Tourinho (2009), a pesquisa narrativa se debruça sobre questões epistemológicas que ajudam a compreender e explicar como práticas culturais, sociais e visuais que marcam a trajetória e a subjetividade dos indivíduos, seus modos de perceber, interpretar e narrar. Preocupam-se também, com a compreensão de como essas práticas configuram ideias, conceitos e representações do nosso cotidiano.

Em Martins (2009), narrar é contar algo sobre o mundo, sobre a existência, sobre o outro ou sobre si mesmo.

É uma maneira de descrever cenários, reinventar a vida, recriar histórias, mas, sobretudo, de recontar eventos, realidades, conflitos, problemas, dúvidas e sentimentos que revelam diferentes versões e perspectivas dos seres humanos. Romances, crônicas, novelas televisivas, ensaios, histórias em quadrinho, tirinhas, fotografias de família, filmes, canções, piadas e até mesmo fatos nas páginas policiais são maneiras de contar, são ações ou acontecimentos que o narrador, ao registrá-los, pode torná-los focos de interesse para posterioridade (MARTINS, 2009, p. 33).

Para o autor as narrativas são revelações orais, escritas, sonoras e visuais que se articulam a partir de vários acontecimentos ou eventos de interesse humano que se unem em uma mesma ação. Uma teia de ideias engendradas por meio de palavras ou escritas e/ou som e imagens são as condições para que as revelações sejam reconhecidas como narrativa.

Como enfatiza Assis (2015, p. 119), a narrativa é um tecido feito de memórias de experiências vividas que revelam dimensões cognitivas, sensíveis e epistemológicas que ajudam na reelaboração dos desejos, dos sonhos e das necessidades; tecidas no interior das práticas e dos discursos culturais institucionalizados, como a família, a escola, a profissão, a religião, elas expõem os modos, os sentidos sobre nós mesmos, sobre os outros e sobre o mundo.

Sabemos que a narrativa pode ser sustentada pela linguagem articulada, oral ou escrita, pela imagem fixa ou móvel, pelo gesto ou pela mistura ordenada de todas essas substâncias. Nesse aspecto, o ponto fundamental da pesquisa é o entendimento das narrativas como espaço investigativo e a possibilidade da imagem se apresentar como narrativa visual, podendo significar a partir de sua própria estrutura e tornando-se capaz de problematizar a multivivência humana. 
Nesta perspectiva, os desenhos, colagens, mensagens de WhatsApp e outras linguagens visuais produzidas pelos alunos de EJA, permitiram construir e reconstruir, com entrecruzamento, percepções e novas significações sobre os temas levantados. Assim, cada visualidade produzida pelos alunos se tornaram ferramentas de reflexão tanto da trajetória da pesquisa quanto dos códigos da nossa visualidade cotidiana.

\subsection{Narrativa Visual}

A apropriação do conceito de imagem de Deleuze e Guattari (apud, Martins, 2008, p. 32) se torna fundamental para explicar o sentido que damos à narrativa visual. Para os autores, as imagens se comportam como membranas que se desprendem da matéria, de superfícies, objetos e estruturas e nos intrigam e questionam porque nos interpelam. Ao serem visualizadas as imagens se deslocam com desenvoltura e mobilidade e ao penetrarem a mente, criam pegadas simbólicas que oferecem conexões rizomáticas.

O grande desafio é como enfatiza Hernández (2007) adquirir um "alfabetismo visual crítico, que permita a análise e a interpretação da multiplicidade de textos existentes na contemporaneidade, tais como, os textos visuais, auditivos, corporais". Esses textos estão postos para serem lidos e compreendidos da mesma forma que um texto escrito.

A narrativa visual seria a compreensão desses textos, ancorados na imagem como uma linguagem que conta uma história, já que apresenta códigos visuais captados no contexto sociocultural e expressam os aspectos cotidianos, tornando possível uma narrativa.

Para o entendimento das narrativas visuais foi fundamental se respaldar nos estudos da cultura visual que considera as visualidades como objeto central, como produtora de significados na vida cotidiana, e definidora de como essas imagens são apropriadas, significadas e resignificadas pelos indivíduos. Para Martins (2014, p. 7), esse campo de estudo se caracteriza por um trânsito entre diferentes áreas do conhecimento que contribuem com seus elementos teóricos e metodológicos, para identificar o universo visual e os modos como este universo produz nossos modos de ver o mundo. 


\subsection{Cultura Visual}

O pensamento positivista de origem francesa tem sua raiz em Auguste Comte (17981857), a sua ideia foi de criar uma ciência capaz de analisar e diagnosticar a sociedade a partir da aplicação das mesmas leis e princípios das ciências da natureza para a explicação e previsão de fenômenos sociais. Nesse contexto, as imagens foram postas de lado pelas correntes de análise empírica, visto que o pensamento positivista ao estabelecer critério de verdade absoluto, subestimou as representações visuais como outra maneira de transmissão de conhecimento e de entendimento do mundo e suas relações.

Somente a partir do final do século XIX e início do século XX é que ocorre uma reaproximação entre a imagem e escrita, na literatura o poeta Frances Mallarmé passa a considerar a visualidade da letra e do branco do papel como elemento de seus poemas. $\mathrm{Na}$ arte, os trabalhos de Picasso e Braque, como os papiers collés introduzem na obra artísticas materiais não artísticos, letras, fragmentos retirados de jornais, partituras musicais. Essa articulação entre imagem e o texto passa a ser uma constante no nosso universo visual contemporâneo.

Atualmente, como observa Hernández (2007, p. 24), "vivemos e trabalhamos em um mundo visualmente complexo", por isso, "devemos ser complexos na hora de utilizar todas as formas de comunicação, não apenas a palavra escrita".

Nesse contexto, surge a cultura visual como um novo campo de estudo e investigações que busca enfocar o universo visual e os modos como este universo produz nossos modos de ver o mundo. Segundo Martins (2014), esse campo se caracteriza por um trânsito entre diferentes áreas do conhecimento que contribuem com seus elementos teóricos e metodológicos, que vinculados uns aos outros favorecem as representações de nosso tempo e leva-nos a repensar as narrativas do passado.

Para esse campo de estudo as imagens são elaborações complexas de sentidos, redes de significados e proliferações de sentidos ligados aos contextos culturais. Tornando-se não apenas representações da realidade, mas também, construtoras de realidades. Como salienta Martins:

A cultura visual se configura como um campo amplo, múltiplo, em que se abordam espaços e maneiras como a cultura se torna visível e o visível se torna cultura. Corpus de conhecimento emergente, resultante de um esforço acadêmico proveniente dos Estudos Culturais, a cultura visual é considerada um campo novo em razão do foco visual com prioridade da experiência do cotidiano (MARTINS, 2004, p. 160). 
Nessa perspectiva segundo o autor, por meio da cultura visual é possível desvelar o cotidiano intermediáticos no qual as imagens são portadoras de significados e de respostas subjetivas construídas numa relação dialógica entre o intérprete e a imagem.

Para situar esse campo de investigação é necessário à recorrência às ideias do educador espanhol Fernando Hernández, que se tornou conhecido por pensar a cultura visual não como um território disciplinar, mas como base para uma definição transdisciplinar de conhecimentos e sua proposta de reorganizar o currículo por projetos. Por esta proposta o professor deixa de ser o "transmissor de conteúdos" para se transformar em um pesquisador e o aluno passa a ser sujeito do seu aprendizado, visto que eles são os protagonistas do processo de criação, procurando respostas e soluções para os problemas levantados.

A sua base de pensamento tem forte influência do filósofo e pedagogo norte americano John Dewey $^{25}$ que defendia a educação como fator de humanização e transformação social.

Hernández (2007) centra o seu interesse nos diferentes materiais visuais para a compreensão das formas pelas quais as pessoas dão sentido às diversas produções culturais ao mesmo tempo que, as experiências cotidianas com o universo cultural criam e disputam significados. Para Hernández,

\begin{abstract}
A expressão cultura visual refere-se a uma diversidade de práticas e interpretações críticas em torno das relações entre as posições subjetivas e as práticas culturais e sociais do olhar. [...] do movimento cultural que orienta a reflexão e as práticas relacionadas a maneira de ver e de visualizar as representações culturais e, em particular, refiro-me às maneiras subjetivas e intrassubjetivas de ver o mundo e a si mesmo (HERNÁNDEZ, 2007, p. 22).
\end{abstract}

Nesse sentido, a cultura visual para o autor, significa associar conceitos sociais e culturais das representações de realidade em instaurar interpretações, questionamentos, reflexões e críticas nas maneiras de visualizar o cotidiano na compreensão social das imagens que nos cercam como expressão de se ver no mundo.

Tavin (2008, p. 11) em seu estudo ao mapear os antecedentes da cultura visual na arte educação nos Estados Unidos nas décadas de 50, 60 e 70, encontra em Vicent Lanier, June King McFee, Laura Chapman e Brent e Marjory Wilson, os educadores que desafiaram os

\footnotetext{
${ }^{25}$ John Dewey na passagem do século XIX para o século XX criticou o sistema educacional norte-americano com seus métodos e técnicas de memorização e transferência do conhecimento; propondo novas técnicas pedagógicas para uma aprendizagem significativa. Seu pensamento deu origem a Escola Nova, pautada no princípio de que a escola deveria atuar como um instrumento para a edificação da sociedade através da valorização das qualidades pessoas de cada indivíduo.
} 
paradigmas dominantes na época, ao colocar imagens da cultura popular como objetos legítimos de estudo na arte educação nos Estados Unidos.

Para Tavin (2008) a contribuição de Vicent Lanier em 1957, está no fato de ter deslocado as fronteiras da arte educação para além das fronteiras eruditas e incorporar a cultura popular, mais voltada para o cotidiano do aluno. June King McFee em 1968, ao explorar a reação entre responsabilidade social e visual e as dimensões físicas do meioambiente, introduz, na arte educação, objetos e imagens da cultura popular e da cultura de massa para que os alunos pudessem avaliar criticamente, atribuindo-lhes significado cultural. Laura Chapman em 1967 oferece alternativas para o estudo da arte de massa para a construção de uma cidadania esclarecida. Brent e Marjory Wilson em 1977 propõem o estudo dos mundos gráficos das crianças, para identificar como as crianças aprendem a desenhar, o que desenham, como modificam seu trabalho e quais os modelos e fenômenos culturais que influenciam suas escolhas gráficas. Para o autor, coletivamente, esses referenciais colocaram as imagens da cultura popular como objetos legítimos de estudo na arte educação.

Nesta perspectiva, o termo cultura visual surge de uma necessidade de mudança impulsionada pelas práticas culturais relacionadas ao olhar, ou seja, como vemos, percebemos e nos relacionamos com o mundo imagético do nosso cotidiano. Ela surge como um campo de estudos relacionado à construção do visual na arte, nas mídias e na vida cotidiana, tendo a imagem como objeto central e por meio da qual são produzidos significados em contextos culturais, ou conforme as palavras de Hernández: "as maneiras subjetivas e intrassubjetivas de ver o mundo e a si mesmo" (2007, p. 22). Assim, Hernández, com o termo cultura visual, sugere um novo rumo para a educação das artes visuais.

A mudança no ensino da arte na escola formal proposta por Hernández (2007) traz explicita a crítica ao planejamento e à elaboração dos currículos escolares, considerados discrepantes quando relacionados à realidade das crianças e dos jovens, visto que os alunos, fora da escola, estão em contato com os diversos meios de comunicação, com uma variedade de imagens, com novas e atraentes tecnologias. As mudanças ocorridas nas diversas áreas sociais tornam inviável a mesma forma de pensar e estruturar a educação.

A proposta de Hernández (2007) pressupõe uma prática educativa fundamentada nas relações sociais, na vivência, na interdisciplinaridade, na reflexão crítica e na autonomia. Ela parte da concepção que o fazer pedagógico é também uma prática política e que não se reduz ao processo de ensino-aprendizagem. Nesta perspectiva, "a Cultura Visual explora as ambivalências, os interstícios e lugares de resistência da vida cotidiana pós-moderna, 
buscando formas de trabalhar com as informações visuais desta nova realidade" (Hernández, 2000, p. 47).

Por essa proposta, os conteúdos são estudados por meio de questões problematizadoras, numa perspectiva globalizadora, inter-relacionando diferentes informações, a partir de um determinado eixo temático. $\mathrm{O}$ entendimento de globalização na educação é no sentido de que "a criança estabeleça relações com outros aspectos de seus conhecimentos anteriores, ao mesmo tempo, vai integrando novos conhecimentos significativos" (Hernández, 1998, p. 50).

A intenção é formar seres pensantes capazes de se posicionar com autonomia diante das diversas linguagens: visual, verbal, sonora ou imagética. Nesse sentido, a principal preocupação dos educadores é mediar e instrumentalizar os alunos para que eles possam fazer suas próprias associações, atribuir significados e emitir opiniões, numa autonomia construída por meio do diálogo entre o aluno, a imagem e o mediador, de forma a derrubar conceitos préformulados, tais como, a obra de arte como algo inatingível ou/e a passividade frente às imagens.

O objetivo é possibilitar a criação de estratégias para facilitar a aprendizagem e a construção do conhecimento. Ensinar o aluno a aprender, a encontrar o nexo, a estrutura, o problema vinculado à informação que se quer e que permite a aprendizagem de forma interdisciplinar.

Sua proposta fica mais clara com o trabalho pensado e desenvolvido na escola Pompeu Fabra de Barcelona e narrado no texto Cultura Visual como um convite à deslocalização do olhar e ao reposicionamento do sujeito (2011, p. 31). Nesse texto o educador espanhol Fernando Hernandez busca responder a seguinte pergunta: Qual é a sua posição ante a cultura visual?

Sua resposta tem como ponto de partida a reflexão sobre a importância da imagem no mundo contemporâneo bombardeado por inúmeros textos imagéticos. O primeiro aspecto discutido pelo autor é a delimitação pedagógica da Cultura Visual, alertando sobre os riscos de redução do tema e enfatizando o hibridismo e o vínculo com outras áreas do conhecimento. O que torna a Cultura Visual, segundo Hernández:

- É um campo de estudo transdisciplinar ou adisciplinar que indaga sobre as práticas culturais do olhar e os efeitos desse olhar sobre quem vê. 
Nesse aspecto, Hernandez identifica uma trama teórico-metodológica que engloba o pós-estruturalismo $^{26}$, os estudos feministas ${ }^{27}$, estudos culturais ${ }^{28}$ e a nova história da arte ${ }^{29}$, dentre outros, com o entendimento da imagem como textos visuais portadores e mediadores de significados e posições discursivas, que contribuem para pensar o mundo e a nós mesmos como sujeitos.

- Um guarda-chuva debaixo do qual se incluem imagens e artefatos do passado e do presente que dão conta de como vemos e somos vistos por esses objetos.

Aqui há influência dos estudos culturais e o seu entendimento dos produtos culturais como representações ou expressões de experiências por intermédio de sistemas codificados de símbolos, ou seja, os efeitos da paisagem visual dos sujeitos na construção cultural do olhar e da identidade. Para Hernandez, este guarda-chuva se articula em torno da dualidade olhardizer. Criar oportunidade de desenvolvimento do olhar crítico, para que as informações sejam transformadas em saberes construídos à luz da criticidade, ou como nos vemos no que vemos.

- Uma condição cultural que, especialmente na época atual, está marcada por nossa relação com as tecnologias da aprendizagem e comunicação que afeta como vemos a nós mesmos e ao mundo.

\footnotetext{
${ }^{26}$ Em termos filosóficos o Pós-estruturalismo é um conjunto de investigações contemporâneas sob forte influência de Nietzsche, nega ou transforma os princípios teóricos do estruturalismo e propõe um pensamento de recusa aos fundamentos tradicionais da filosofia, como as ideias de verdade, objetividade e razão. Tendência observada entre os intelectuais franceses, destacando-se no campo filosófico: Jacques Derrida, Gilles Deleuze, Jean-François Lyotard; na Psicanálise: Jacques Lacan; no campo político e sociológico: Louis Althusser e Michel Foucault e na análise literária: Roland Barthes e Maurice Blanchot. Além destas referências, também pode ser considerados pós-estruturalistas: Giogio Agamben, Jean Baudrillard, Judith Butler, Félix Guatarri, Fredric Jameson, Julia Kristeva, Sarah Kofman, Philippe Lacoue-Labarthe e Jean-Luc Nancy.

27 Filosofia que reconhece que homens e mulheres têm experiências diferentes e reivindica que pessoas diferentes sejam tratadas não como iguais, mas como equivalentes. As feministas denunciam que a experiência masculina tem sido privilegiada ao longo da história, enquanto a feminina, negligenciada e desvalorizada. Elas demonstraram, ainda, que o poder foi e ainda é, predominantemente masculino e seu objetivo original foi a dominação das mulheres, especialmente de seus corpos. O movimento feminista contemporâneo é o reflexo das transformações do feminismo original, predominantemente intelectual, branco e de classe média, configura-se como um discurso múltiplo e de variadas tendências, embora com bases comuns. As feministas destacam que a opressão de gênero, de etnia e de classe social perpassa as mais variadas sociedades ao longo dos tempos. Esta forma de opressão sustenta práticas discriminatórias, tais como o racismo, o classicismo, a exclusão de grupos de homossexuais e de outros grupos minoritários.

${ }^{28} \mathrm{O}$ Estudos Culturais tem origem na movimentação e grupos sociais que buscam se apropriar de instrumentos, ferramentas conceituais e saberes que emergem de suas leituras do mundo, repudiando aqueles que se interpõem, ao longo dos séculos, aos anseios por uma cultura pautada por oportunidades democráticas, assentada na educação de livre acesso. Um a educação em que as pessoas comuns pudessem ter seus saberes valorizados e seus interesses contemplados. Desde o seu surgimento, os Estudos Culturais configuram espaços alternativos de atuação para fazer frente às tradições elitistas que persistem exaltando uma distinção hierárquica entre alta cultura e cultura de massa, entre cultura burguesa e cultura operária, entre cultura erudita e cultura popular.

${ }^{29}$ Nova história da arte é a denominação resultante dos desafios e questionamentos sofridos pela História da Arte que derivam de um enorme alargamento de campo, da multiplicação dos objetos e das múltiplas perspectivas de análise, originadas pela evolução dos estudos culturais, que fez implodir e alargar o campo tradicional, pondo em causa a própria subsistência da História da Arte.
} 
É possível perceber o que, para o autor, não é cultura visual: não é um quê (objetos, imagens), nem um como (um método de análise e interpretação do que vemos), mas sim um cruzamento de olhares, sem uma ordem estabelecida (os do passado e os do presente). Nessa perspectiva, os objetos não têm vida, mas adquirem sentido pela experiência de quem os olha e os possui. Ao mesmo tempo, os objetos são fonte de conhecimento, que nos instigam a aprender com eles, exploram as fontes das quais se nutrem não apenas nossa maneira de ver/olhar, mas os significados que nós fazemos, e que formam parte de outros relatos e referências culturais.

Ao explorar as representações que os indivíduos, de acordo com suas características sociais, culturais e históricas, constroem da realidade e como se representa para compreender as próprias representações; muda-se o foco do olhar e do lugar de quem se vê. Dessa forma, na cultura visual não há leitores, como enfatiza a tradição do olhar ocidental sobre a arte e as imagens; mas sim construtores e interpretes na medida em que a apropriação não é passiva nem dependente.

Como atenta Lampert (2015, p. 247), a escola como um espaço de criação de percepções, instauradora de sentido sobre o cotidiano deve definir estratégias para estudar genealogia, definições e funções da vida cotidiana pós-moderna, refletindo mais sobre a perspectiva do consumidor do que a perspectiva do produtor de visualidades.

Observa-se que a noção de cultura visual é interdisciplinar e busca referências nas diversas áreas do conhecimento, podendo ser entendida a partir de Hernández, “como espaço de relação que traça pontes no vazio, que se projeta entre o que vemos e como somos vistos por aquilo que vemos" (2011, p. 34); um espaço que permite a experiência com a imagem, incorporando problematizações que escapam à tradicional abordagem da arte na educação. Daí a necessidade de revisar os sentidos da relação das artes visuais com a educação.

Dessa forma, a abordagem pautada na cultura visual vai além do estudo do material visual, mas reflete e analisa como o universo visual, subentendido como aquilo que se vê e a visualidade - modos de ver e as tecnologias da visão estão nos constituindo, ou seja, como elas são produzidas, distribuídas e utilizadas socialmente, como prática cultural que produz e negocia significados. Para Hernández (2000, p. 52), a cultura visual contribui para que os indivíduos fixem as representações sobre si mesmas e sobre o mundo e sobre seus modos de pensar-se, melhor dizendo, como olhamos e como nos olhamos e como produzimos o mundo.

Na concepção de Hernández (2000) somente vemos aquilo que faz sentido dentro de nossas vivências socioculturais, o que determina que a visualidade esteja relacionada com os 
contextos imagéticos culturais e com os significados que construímos em torno deles. Além disso, os significados das imagens são construídos nas interações sociais e culturais que realizamos com elas. Os contextos sociais e culturais dão existência aos materiais visuais atribuindo-lhes significados, sendo que o sentido não emana das imagens, mas dos diálogos produzidos entre elas e as pessoas, e estes diálogos mediados pelos contextos culturais e históricos.

Hernández (2000) utiliza a metáfora do rizoma e do fractal de Deleuze e Guattari para indicar que as diferentes perspectivas de estudo, que caracterizam os estudos da cultura visual derivam de uma estrutura multidisciplinar. Como o rizoma, constitui-se não de uma massa homogênea, mas de uma pluralidade de atores e comunidades. Como o fractal, possui várias interfaces em permanente interação e expansão. Os estudos culturais constituiu-se um espaço intersticial onde as relações se reconstroem a partir de circunstâncias, de informações e posições de sujeitos que configuram o olhar.

Como assinalado por Martins (2015, p. 24) em seu texto: A cultura visual e a construção social da arte, da imagem e das práticas do ver, "o olhar sempre está traspassado por condições e referentes que se superpõem tais como classe, raça, idade, estilo de vida, preferências sexuais e muitas outras". Significando que no estudo desse campo é importante a intersecção destes elementos para o esclarecimento das operações e formas de visualização e de posições discursivas complexas.

No Brasil, como observa Dias (2008, p. 38), a cultura visual é um campo emergente de pesquisa transdisciplinar e trans-metodológica, que estuda a construção social da experiência visual, deslocando a atenção da cultura de elite, para a visualização do cotidiano.

O entendimento das imagens como uma rede de significados e relações que não obedecem a uma estrutura de causa-efeito, indica que elas ligam, com sua teia de relações, contextos e significados político, religiosos, psicológico, econômico ou social. Como observa Nascimento (2012), as interpretações visuais têm uma cultura que afeta tanto o processo de produção como o de recepção e as imagens são construídas a partir de um repertório cultural, forjado no passado, e que, no presente, fixam e disseminam modos de compreensão do mundo.

Nessa dinâmica, compreende-se as narrativas visuais como um instrumento capaz de refutar os discursos e construções hegemônicas do mundo contemporâneo. Sendo os sentidos construídos numa relação dialógica entre o intérprete e a imagem, como salienta Martins (2007), ao se desprender do seu contexto, a imagem gera uma multiplicidade de novas 
significações, tecendo sentidos num processo relacional que envolve montagem, seleção, recorte e exclusão.

Tecer este conhecimento é indagar sobre nós mesmos, refletir sobre as forças que restringem nossas vidas e compreender que nossa identidade se constitui a partir de um outro olhar sobre nossa própria trajetória.

Esta é a proposta de Hernández (2015), ao ressaltar a necessidade de uma formação de professores em um contexto de mudanças e que considere outros espaços que não apenas os institucionalizados das artes visuais e da docência. Para Hernandez (2015, p. 29): "ser docente, pai e mãe não são realidades essenciais, senão sociais, discursivas, e como tais, modificáveis, produtos de cada época e contexto". Nesta perspectiva temos a pesquisa desenvolvida por Cardonetti e Oliveira (2015, p. 53), utilizando o diário individual produzido no decorrer do semestre pelos alunos como um "espaço narrativo dos pensamentos, expressando em versões textuais e/ou visuais as impressões que havíamos tido das intervenções". A experiência mostrou que o compartilhamento das narrativas dos diários pode ser visto como um espaço disparador do pensar.

Estas experiências têm demonstrado que os deslocamentos perceptivos e conceituais da cultura visual ampliaram os "espaços e maneiras como a cultura se torna visível e o visível se torna cultural" (Martins, 2015, p. 91).

\subsection{Cultura Visual e o Currículo de Arte - EJA}

Conhecer como a cultura visual é apresentada na proposta curricular de Arte para a Educação de Jovens e Adultos, nos levou à reflexão sobre a organização do currículo: se ele contempla as visualidades contemporâneas e atende às demandas da modalidade de Educação de Jovens e Adultos.

O interesse foi perceber quais as significações que permeiam o currículo de EJA da Secretaria de Estado de Educação do Distrito Federal. Em seu estudo acerca dos currículos Santos (2000) observa a existência de duas grandes tendências que marcam os estudos e as práticas curriculares. De um lado, aquelas que veem o currículo como um conjunto de conteúdos e de outro lado, aqueles que defendem a ideia de que o currículo se constitui das experiências e vivências na escola ou sob sua supervisão.

A segunda tendência, apontada por Santos (2000) permeia o currículo EJA, envolvendo as situações práticas, os problemas do cotidiano e as experiências dos alunos. A 
instauração do diálogo na escola se torna fundamental para consolidar os saberes construídos por meio da prática profissional reflexiva, pela qual são construídas novas significações.

Diferentemente do currículo como conjunto de conteúdo, ou seja, o currículo como prescrição, Irene Tourinho (2008, p. 71) compreende-o como um artefato social e histórico sujeito a mudanças. Sugere a construção de um currículo com o poder de contribuir para fortalecer o sentido de pertencimento entre alunos, professores e bens culturais. Para isso, é necessário, segundo a autora, repensar categorias e conceitos que conduzem o pensamento educacional e problematizar processos que ocorrem dentro ou fora das escolas e salas de aula.

Ainda, em relação ao currículo de Arte, Tourinho (2009), em seu artigo Currículo para além das grades: de porões a terraços, praças e jardins, analisa quatro propostas curriculares do ensino de Arte e observa que estes documentos, ora privilegia uma concepção técnica-universalista - currículo como expressão de tudo que existe na cultura, ora se pauta em uma perspectiva processual-culturalista - currículo como espaço de cultura que se faz na interação e negociação entre alunos e professores.

O Currículo em Movimento da Educação Básica - Educação de Jovens e Adultos da Secretaria de Educação do Distrito Federal (2014), pode ser entendido como partidário das experiências culturais dos alunos, ao considerar:

\footnotetext{
Os estudantes da EJA [...], são sujeitos com conhecimentos e experiências (empíricas) dos saberes feito, com trajetórias constituídas no exercício de suas práticas/relações sociais, com experiências, acumuladas que os tornam partícipes de seu próprio aprendizado. Esses saberes já constituídos se tornam currículos importantes na medida em que falam de seus lugares e atravessam todos os processos construtivos das aprendizagens significativas (SEEDF, 2014, p. 22).
}

A estrutura curricular tem como eixos integradores: cultura, trabalho e tecnologias. Entendendo-se como cultura a acumulação dos saberes constitutivos do ser humano em sua amplitude; como trabalho, a produção social da vida e parte essencial dos sujeitos estudantes da EJA; e a inclusão das tecnologias como inserção social, tanto digital como socialização e diálogo com o mundo.

O conteúdo de Arte está incluído na área de conhecimento: Linguagens Códigos e suas Tecnologias e Redação, abrangendo Língua Portuguesa, Língua Indígena, Língua Estrangeira Moderna e Arte em suas diferentes linguagens: cênica, plástica e musical, além da Educação Física.

A compreensão da disciplina de Arte como linguagem, segundo análise de Tourinho (2009, p. 55), prevalece a ideia de obra de arte, desconsiderando-a no mundo saturado de 
mensagens e informações visuais, sonoras, gestuais, orais e outras metáforas para pensar a cultura estética.

É possível perceber pouca sintonia entre o que está sendo discutido na academia e o que está sendo executado na sala de aula. Apesar do currículo apresentar aspectos inovadores da arte como linguagem, representação, comunicação e compreensão do mundo, ainda predomina, no cotidiano escolar, práticas pedagógicas tradicionais, distantes da dinâmica do nosso tempo.

Victorio Filho em seu artigo, Enfretamentos contemporâneos no ensino formal das artes: cultura visual, o corpo e a arte (2013), alega que o ensino de arte ainda se apresenta territorializado no espaço curricular de proteção e pertencimento. Um sistema que muitos de seus professores desconhecem ou conhecem parcialmente, tendo como objetivo a ideia de aprimoramento cultural e educação estética.

Entretanto, o autor observa que a educação estética é entendida como tributária dos padrões estéticos ocidentais, interferindo no critério para as escolhas dos conteúdos e privilegiando a história e obra de arte. Consequentemente os saberes estéticos e ou poéticos do cotidiano são descartados como se não fizessem parte da formação dos alunos e do componente curricular de Arte.

O resultado, segundo Victorio Filho (2013), é que o ensino de arte nas escolas, ao eleger o conjunto de obras legitimados pelo sistema comercial do mercado outorgado pela produção da história e pela crítica oficial da arte, desqualifica as fontes de saberes relativos à diversidade cultural, as imagens, as criações poéticas e as identificações estéticas.

O autor propõe o investimento na cultura visual, nas formas de ver, na constituição dos olhares, na tessitura dos modos de ver e viver. Para isso, sugere reconhecer o olhar no corpo que o realiza, ou seja, trazer para a discussão "o corpo do aprendiz que vibra em sua singularidade e fortalece os coletivos nos quais acontece, nos quais se movimenta e dos quais faz o movimento" (Victorio Filho, 2013, p. 3206).

A partir dos estudos sobre a cultura visual podemos afirmar que prevalece uma distância nos debates travados nas universidades e o que está sendo executado em sala de aula, sinalizando que o ensino público de Arte no Distrito Federal, pode também, além de das diretrizes curriculares que o orientam, acolher a cultura visual na incorporação de reflexões acerca das visualidades cotidianas. 


\section{NARRATIVAS VISUAIS DOS ALUNOS}

O entendimento de escola como espaço de vivências, interações e mediações culturais nos impulsionou a interagir nos espaços escolares do CED 01 de Planaltina e do CEM 03 de Ceilândia, com os objetivos de apreender a narrativa visual dos alunos de EJA na sua relação com as visualidades no espaço urbano; refletir como eles veem a cidade onde vivem e compreender se as visualidades cotidianas afetam a leitura do mundo e como essa leitura é influenciada pela experiência de vida do aluno. Para isso, foram planejados quatro momentos vivenciados nas aulas da disciplina Arte.

No primeiro momento foi apresentada aos alunos a proposta de trabalho com seus objetivos, e aplicado o questionário. Os outros momentos foram destinados às produções das narrativas visuais, em três fases e temas: "Lugares de lembrar a infância", "Lugares de lembrar a cidade e sua inserção" e "Lugares de sonhar: perspectivas futuras".

Em todos os momentos buscou-se compreender como os alunos representam e desvelam visualmente os fragmentos de lembranças da infância, da cidade e sobre as suas perspectivas futuras. Tendo em mente que as imagens dissolvem-se nas lembranças, dispersam-se na imaginação, evaporam-se nas mentes, relatos e memórias, como afirma Raimundo Martins (2010), acreditamos que as narrativas visuais dos alunos jovens e adultos das escolas referendam seus modos de ser, viver, pensar, sentir, brincar, sonhar e relacionar-se com seu cotidiano no espaço urbano que vivem.

A compreensão de que as imagens, como produto social, histórico e cultural, "traduzem noções, crenças e valores, registram informações culturais e práticas de diferentes períodos" (Martins, 2007, p. 53) foi o motor para apreender as narrativas visuais dos alunos. A intenção era levá-los a vivenciar suas visualidades com as reproduções de seus olhares é como esclarecem Alice Martins e Raimundo Martins (2014, p. 7), “impulsionar para compreender as experiências e os artefatos visuais que nos projetam no mundo e/ou que nos colocam em diálogo com o mundo".

Nesse contexto, Michel de Certeau (2002) ao refletir sobre a insuficiência e a inconveniência dos métodos acerca dos estudos do cotidiano, discute o desenvolvimento de um outro conhecimento - o da escola e de suas práticas cotidianas, daqueles que nela atuam. Sugerindo para isso, a análise das práticas microbianas, singulares e plurais, entendendo ser necessário: 
Seguir o pulular desses procedimentos que, muito longe de ser controlados ou eliminados pela administração panóptica, se reforçaram em uma proliferação ilegitimada, desenvolvidos e insinuados nas redes de vigilância, combinados segundo táticas ilegíveis, mas estáveis a tal ponto que constituem regulações cotidianas e criatividades sub-reptícias que se ocultam somente graças aos dispositivos e aos discursos, hoje atravancados, da organização observadora. (CERTEAU, 2002, p. 175).

Nessa perspectiva, Certeau (2002, p. 40) ao discutir a cristianização forçada dos indígenas da América do Sul pelos colonizadores hispânicos, observa que olhando de fora, os nativos pareciam submeter-se totalmente ao conformar-se com as expectativas do conquistador; entretanto, eles "metaforizavam" a ordem dominante, fazendo funcionar as leis e suas representações num outro registro, no quadro da própria tradição. Os indígenas subvertiam as leis do colonizador para fins e referências próprias, embora não rejeitassem, as contornavam.

Segundo Certeau (2002, p. 63), essas escrituras invisíveis só são lembradas por novas circunstâncias quando atingidas por toques. A memória é tocada pelas circunstâncias e não está fixada ao passado, como um tempo morto e desvinculado de um aqui e agora. Muito pelo contrário, são esses registros imagéticos que afetam nossas vivências e nos fazem nos posicionar diante do mundo.

A presença e a circulação de uma representação não indicam, de modo algum, o que ela é para seus usuários, é preciso analisar a sua manipulação pelos praticantes que não a fabricaram para poder apreciar a "diferença ou a semelhança entre a produção da imagem e a produção secundária que se esconde nos processos de sua utilização" (Certeau, 2002, p. 40). Nesse sentido, o autor propõe "a construção de frases próprias com um vocabulário e uma sintaxe recebidos", acreditando que pelas maneiras de usar essa produção, pelas invenções cotidianas, pelas maneiras de fazer, incide nos usuários, a exemplo dos povos indígenas, uma "bricolagem" na economia cultural dominante, segundo os interesses e regras próprias de seus usuários. Assim, a legitimidade da "autoridade", a expressão daquilo que é "aceito" como “crível”, se constrói pelas representações que vão se articulando em torno dela. Para essa articulação, segundo o autor, são necessários sinais de reconhecimentos e acordos realizados acerca das condições de possibilidades para que seja aberto um espaço onde se desenvolva. São essas representações aceitas que inauguram e ao mesmo tempo exprimem essa nova credibilidade.

Por sua vez, Martins (2012, p. 145) afirma que o modo como captamos as imagens por nossos olhos e acrescentamos também os demais sentidos, "afetam e refletem aspectos do nosso entorno, como as relações sociais e o modo de vida: a percepção de qualquer imagem é 
afetada pelo que sabemos, pensamos e, especialmente, pelas nossas convicções e crenças". Essa afirmação nos leva a pensar que as imagens incorporam uma forma de ver, que por sua vez, interferem na nossa maneira de interpretar, como também, o que vemos não afeta apenas a nossa interpretação do mundo, mas o nosso modo de viver.

A proliferação de imagens no mundo contemporâneo tem levado ao desenvolvimento de diversas pesquisas que procuram demonstrar que a compreensão de textos e imagens é sempre uma narrativa, já que ao ler ou olhar um texto, inserimos elementos que vemos ou lemos numa estrutura narrativa que nos ajuda a produzir sentidos sobre eles. Ao olhar uma imagem associamos informações que captamos a outras imagens que conhecemos de forma simbólica ou codificada.

Nessa perspectiva, as visualidades cotidianas que nos cercam transformam não só o nosso mundo e as nossas identidades, mas têm um papel cada vez mais importante na construção de nossa realidade social.

Nesse aspecto, destaca-se a pesquisa realizada por Nunes e Martins (2014, p. 169), em uma escola da rede pública da cidade de Goiânia/GO, que teve como objetivo entender a constituição de subjetividades na mediação com artefatos culturais em sala de aula. A autora observa que existe uma distância entre os conhecimentos escolares e os conhecimentos do cotidiano infantil nas práticas pedagógicas, e aponta a educação da cultura visual como um convite para educar a infância líquida ${ }^{30} \mathrm{em}$ uma sociedade caracterizada pela incerteza.

Além disso, as visualidades nos levam a refletir sobre as estratégicas de controle do espaço público e de resistência por meio da busca do anonimato e das formas singulares de apropriação do espaço da cidade.

Como definição de cidade utilizamos aquela contida no estudo de Raquel Rolnik (1988), como sendo um espaço de confluência de dinâmicas econômicas, políticas, sociais, demográficas, culturais e simbólicas, por isso, a cidade é uma complexa realidade que envolve todas estas dinâmicas. Para a autora, a cidade guarda marcas de vários tempos e processos sociais no espaço urbano construído, materializando assim, sua própria história como uma espécie de escrita no espaço, tornando-a uma realidade plural e polifônica, já que o espaço pertence a diferentes sujeitos e grupos sociais. Nesse entendimento, os grupos sociais tanto constroem a cidade quanto um tecido de relações sociais e representações.

\footnotetext{
${ }^{30}$ O termo 'líquido' foi utilizado por Bauman (2001) para explicar a pós-modernidade, associando à leveza, a qual, por sua vez, denota mobilidade e inconstância. No caso, a autora utilizou o termo infância líquida para definir a impossibilidade de definição ou demarcação de conhecimentos sobre o que é ser criança na contemporaneidade.
} 
A dinâmica da cidade é reveladora de processos sociais mais amplos que dizem respeito não só ao bairro e à cidade onde está situado, mas também, às características de zonas urbanas de metrópoles contemporâneas. É com base nesse conhecimento que se procura compreender a narrativa dos alunos que foram orientados a "passear" pela cidade e registrar o seu olhar na passagem pela rua. A intenção era apreender algumas percepções dos alunos como flâneur ${ }^{31}$.

A palavra foi utilizada por Walter Benjamin (2000) para discorrer sobre o poeta Baudelaire e sua relação com a cidade de Paris. Segundo Benjamin (2000), Baudelaire percebeu as transformações que ocorriam no espaço urbano com a industrialização, exigindo um novo olhar, urgente e necessário para esse novo homem, para que assim ele buscasse se entender frente a tantas transformações.

Esse novo olhar que surgia entre a multidão era o do flâneur. Para Benjamin (2000, p. 56), aquele que "vê a cidade sem disfarces", aquele que possui a arte de flanar percorrendo os sentidos da cidade, o que possui o saber integral da cidade, do seu perto e do seu longe, do seu presente e do seu passado.

Ao perambular pelas ruas das cidades de Planaltina e Ceilândia, os alunos procuraram apreender imagens da cidade, tornando-se uma espécie de flâneur urbano, a andar a esmo, olhar e captar imagens recortadas do mundo da cidade.

A apreensão destas visualidades foi realizada a partir da produção de desenhos colagens, textos e também, embora opcional, as imagens e mensagens enviadas pelo aplicativo do WhatsApp. Estas imagens se tornaram narrativas que contam histórias, evidenciam cenários socioculturais que expressam os aspectos cotidianos e desvelam a forma como os alunos veem a cidade e interagem em seus espaços.

\subsection{Narrativa Visual dos Alunos - CED 01 de Planaltina}

A seguir a exposição das apreensões das narrativas visuais dos alunos do Centro Educacional 01 de Planaltina, "Centrão", composta pela produção de oito alunos que participaram dos quatros momentos da prática pedagógica e suas respectivas expressões do espaço urbano da cidade de Planaltina.

\footnotetext{
31 A palavra francesa flâneur do verbo flâner (passear) aparece significando "vagabundo", "vadio", "preguiçoso". O termo foi apropriado por Charles Baudelaire para designar uma pessoa que anda pela cidade a fim de experimentá-la. A ideia foi utilizada por Walter Benjamin para descrever um produto da vida moderna e da Revolução Industrial capaz de desvelar fenômenos urbanos e da modernidade.
} 


\subsubsection{Narrativa Visual - Aluno P-Oito}

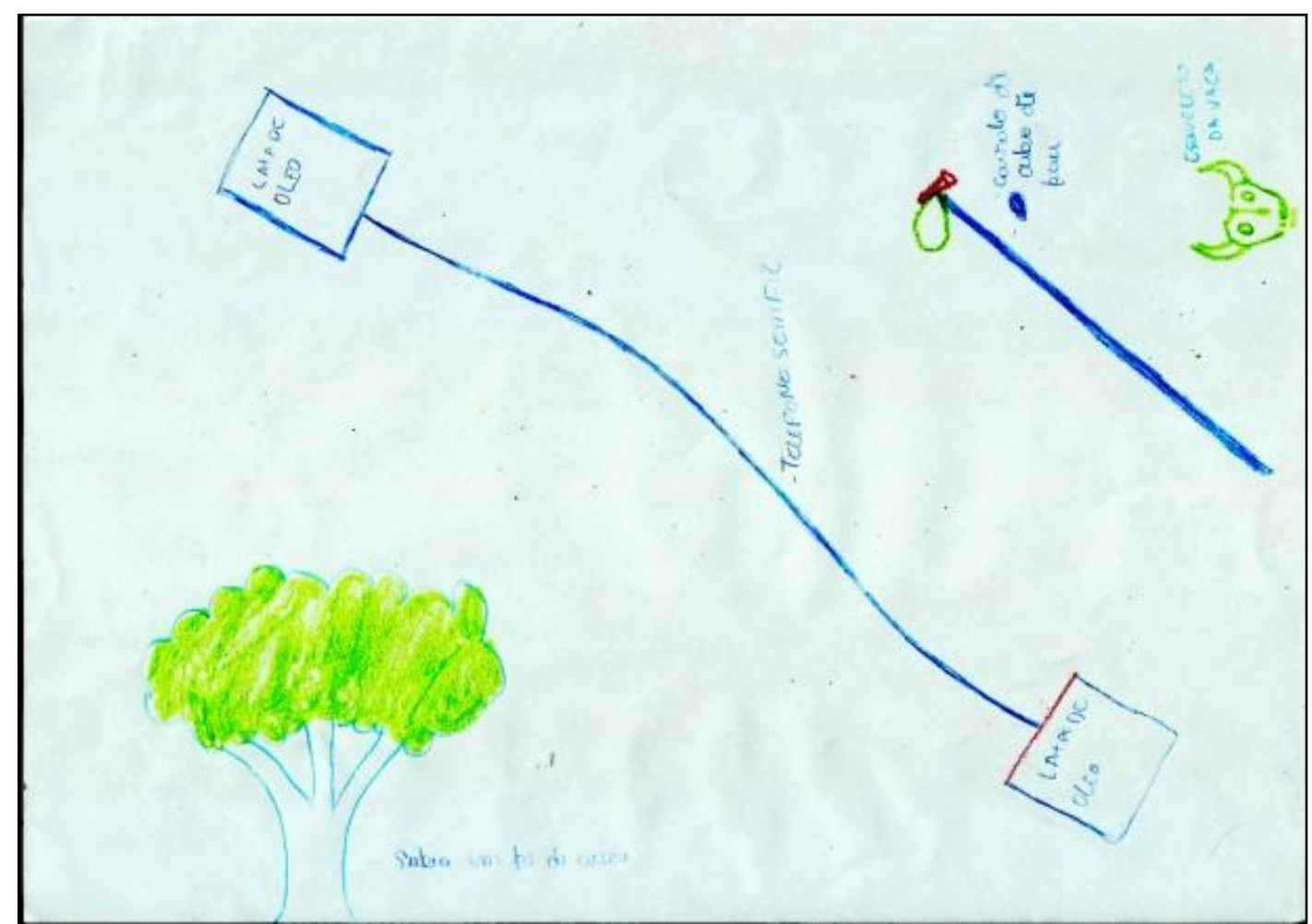

Figura 25. Lugares de lembrar a infância - aluno P-Oito. CED 01 de Planaltina-DF, 2015.

A narrativa visual do aluno acerca da infância, figura 25, com traços simples e com emprego de algumas palavras (lata de óleo, cavalo de cabo de pau, esqueleto da vaca, subir em árvore), sobre uma folha em branco, deixa aparecer fortemente o verde da árvore e da ossada do animal. A partir da visualidade é possível fazer algumas observações, como por exemplo, que se trata de uma criança que se apropria dos espaços abertos, o que pode ser comprovado pelo tipo de brincadeira: subir em árvore para pegar seus frutos, telefone sem fio, cavalo de pau e brincadeiras com esqueleto de animais.

É possível interpretar que, provavelmente, a criança não pertença a uma classe econômica privilegiada. A dedução é feita pelo fato da criança não ter produzido em sua narrativa brinquedos industrializados mas, ela mesma tê-los confeccionado se apropriando de sucatas e materiais orgânicos. Como exemplo, o telefone sem fio feito a partir de duas latinhas ligadas por um fio de barbante e o cavalo de pau feito com cabo de vassoura, bambu ou vara. É possível depreender que o espaço vivido pela criança não era totalmente urbano, podendo ser encontradas carcaças de animal na rua, fato característico do meio rural. Outra possível dedução é que as brincadeiras infantis não estavam restritas à casa ou escola, apresentava uma variedade de brincadeiras de rua. 
Esses brinquedos e brincadeiras populares são considerados como parte da cultura e são transmitidos de geração para geração, por meio da oralidade. Os brinquedos e as brincadeiras, muitas vezes preservam sua estrutura inicial, outras se modificam, recebendo novos conteúdos.

A narrativa do aluno ao ser comparada à contemporaneidade, nos faz lembrar as ideias de Ariès (2006), que a infância de acordo com a época e a sociedade, assume diferentes sentidos e papéis, sendo assim a concepção de infância historicamente construída vai se modificando de forma heterogênea em uma mesma sociedade e período.

Atualmente, a revolução eletrônica e o avanço tecnológico têm refletido no sentido do que é ser criança, já que a internet possibilitou o surgimento de novas formas de comunicação e difusão das informações. Hoje as crianças jogam em ambientes virtuais acelerados de luz artificial, focadas em sequências frenéticas de imagens. A linguagem visual ocupa cada vez mais espaço, em detrimento do verbal, corporal, gestual e escrita.

As construções discursivas, sociais e culturais de infâncias, materializadas ou corporificadas em imagens, é o tema do estudo desenvolvido por Nascimento em seu artigo Visualidade e infância até seis anos: versões em imagens e os desafios da educação infantil (2010, p. 15). Nele o autor conclui que o conceito que temos da infância é uma invenção do adulto, por isso a necessidade de rever os processos de ensino e aprendizagem vivenciados nos estabelecimentos de ensino dos diversos níveis educacionais, principalmente na educação infantil.

Esta ideia da infância é reforçada no artigo de Tourinho e Martins (2010, p. 37), Culturas da infância e da imagem aconteceu um fato grave, um incidente global, no qual a criança é um conceito modelado por forças sociais, culturais, políticas, econômicas e religiosas. Os autores demonstram que a partir das narrativas fílmicas é possível criar condições para refletir sobre as diferentes visões e versões da criança e seu mundo.

A narrativa do aluno também nos desafia a pensar o processo de ensino e aprendizagem, visto que teoricamente eles foram pensados em outro contexto, como por exemplo, a teoria de Vigotsky ao afirmar que as brincadeiras são imprescindíveis para que a criança desenvolva a imaginação, o espírito de colaboração, a socialização e para auxiliar a compreender melhor o mundo. Para o autor, "a imaginação em ação ou brinquedo é a primeira possibilidade de ação da criança numa esfera cognitiva que lhe permite ultrapassar a dimensão perceptiva motora do comportamento" (Vygotsky, 1984, p. 56). 


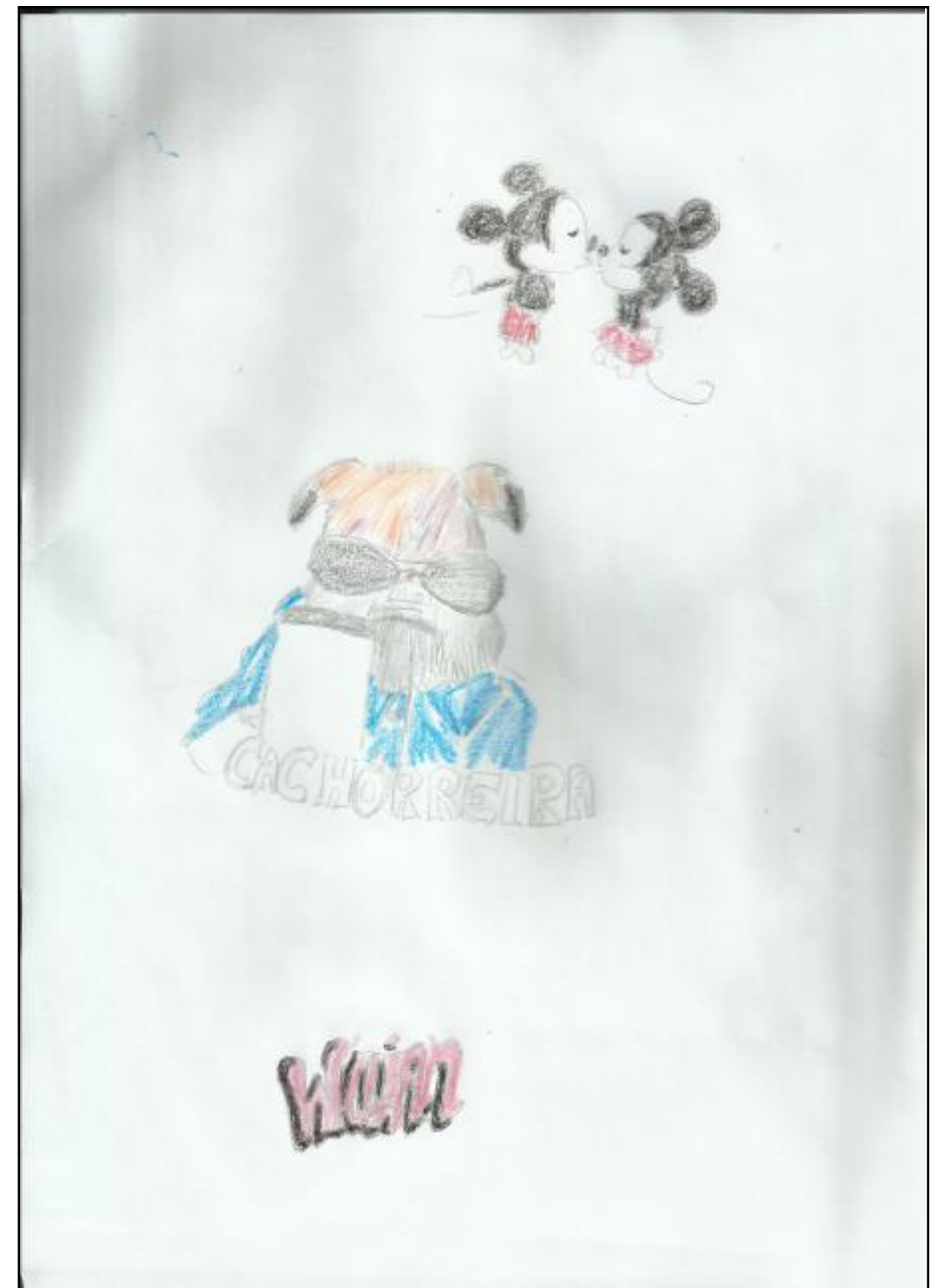

Figura 26. Lugares de lembrar a cidade e sua inserção - aluno P-Oito. CED 01 de Planaltina-DF, 2015.

O mesmo aluno ao falar da cidade apresenta a narrativa na figura 26, elaborada em um fundo branco com tons negros, rabiscados de azul e vermelho, reproduz elementos dicotômicos de influências visuais, por um lado, os desenhos animados da Disney e por outro, gíria "cachorreira" ligada ao movimento Funk.

O movimento Funk surgiu a partir do soul, do jazz e de outros gêneros ligados às inovações musicais dos negros norte-americanos na década de 1960. Apesar do termo funk no Brasil, não possuir o mesmo significado do funk americano, a sua popularização incorpora o ritmo contagiante, considerado uma manifestação cultural à margem da indústria da música e da mídia. 
No vocabulário do funk, "cachorreira" significa "garoto transudo que pega todas"32. Alguns exemplos são apresentados na Internet: "Esse mino é muito cachorreira" (rapaz sedutor, namorador, galanteador, etc). Também o nome é atribuído a um cantor de funk: MC Phe Cachorreira, que se destacou com sua música de protesto contra o aumento das passagens de ônibus em São Paulo-SP: Paga 3,80 - A Passagem Aumentou ${ }^{33}$.

Na narrativa do aluno é visível a influência dos desenhos animados da Disney com o casal Mickey e Minnie. É possível também fazer algumas deduções que nos remetem à hegemonia norte-americana no mundo do pós-guerra trazendo consigo os novos sinalizadores de modernidade: automóveis, filmes, cosméticos, discos, máquinas de escrever, fonógrafos e aparelhos de barbear, em um contexto no qual os Estados Unidos emergem como os herdeiros dos sistemas imperialistas que se haviam desfeito ou se desagregavam. Os porta-vozes desta modernidade são homens de negócios e publicitários norte-americanos. No Brasil, o processo de disseminação da cultura norte-americana ocorreu em meados do século XX, iniciando com a chegada de astros de Hollywood e dos personagens de Walt Disney - Pato Donald, Mickey, Tio Patinhas e outros, vistos como agentes destruidores das tradições culturais da criança latino-americana ${ }^{34}$, instruindo a avareza, o individualismo e o materialismo consumista norteamericano às crianças.

A narrativa visual do aluno nos remete ao artigo de Cunha (2014, p. 199) Imagens como pedagogias culturais em cenários da educação infantil, no qual a autora observa que as imagens presentes nas instituições infantis são as mesmas que acessamos diariamente; entretanto, elas compõem uma espécie de mestiçagem cultural já que são adulteradas de suas origens de produção e passam a compor outras narrativas distantes dos contextos onde foram produzidas. Para a autora, uma infinidade de artefatos como imagens, objetos, livros, filmes, cromatismos, vestuários, entre outros artefatos visuais, elaboram narrativas em torno de como e o que estas infâncias são para nós e para as próprias crianças.

Para apreensão da narrativa acerca dos sonhos e perspectivas futuras, figura 27 , a seguir, foi desenvolvida em uma dinâmica na qual o aluno foi instigado a pensar: Quais os sonhos, desejos, objetivos e projetos de vida que pretende realizar?

\footnotetext{
${ }^{32}$ Significado de cachorreira; http://www.dicionarioinformal.com.br/significado/cachorreira/22374/. Acesso em $17 / 06 / 2016$.

${ }^{33}$ Site Imperador do Funk: http://www.funk.blog.br/2016/02/mc-phe-cachorrera-paga-380-passagem.html\#more. Acesso em 17/06/2016.

${ }^{34}$ Ver estudo Antônio Pedro Tota que analisa o processo de americanização da sociedade brasileira através de programas de rádio, do cinema, dos cartoons e outras manifestações culturais como uma forma de disseminar uma imagem favorável dos Estados Unidos no Brasil para garantir a unidade pan-americana na luta contra o Eixo. O Imperialismo sedutor: a americanização do Brasil na época da Segunda Guerra. São Paulo: Companhia das Letras, 2000.
} 
Em um formulário, com o desenho de uma árvore, o aluno deveria escrever um sonho, um desejo, um objetivo ou um projeto de vida (na copa); as ações possíveis para concretizar o que foi sonhado e/ou projetado no (tronco da árvore); e finalmente, deveria identificar as bases que estruturam o seu projeto de vida (raiz da árvore).

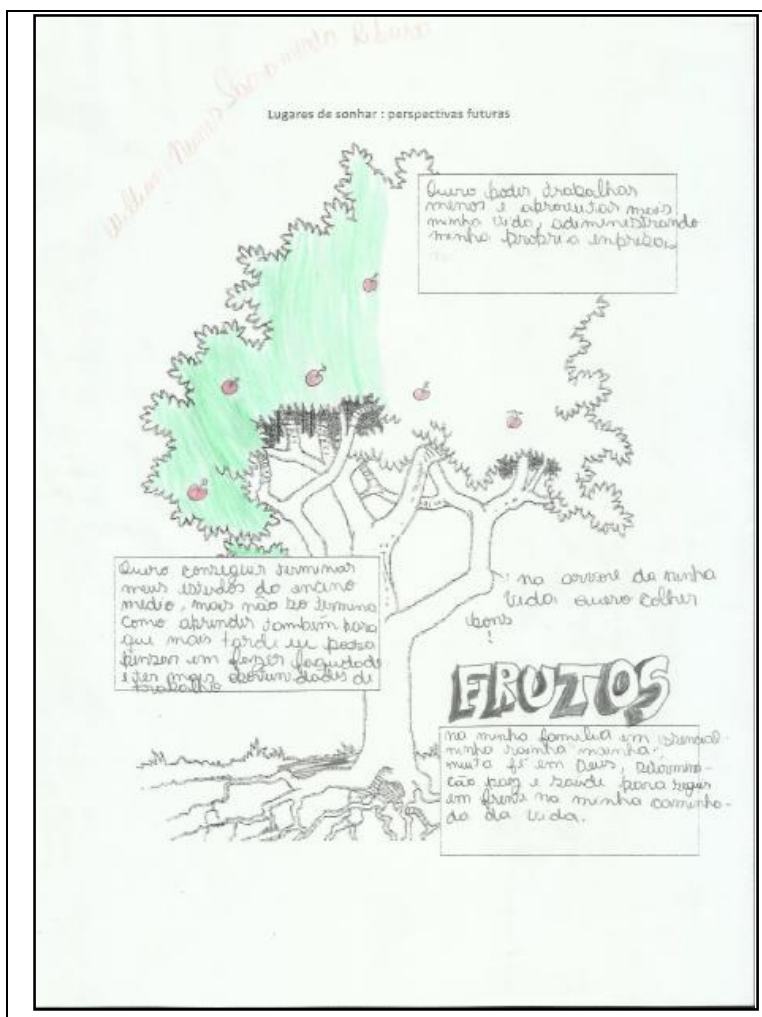

Figura 27. Lugares de sonhar: perspectivas futuras aluno P-Oito. CED 01 de Planaltina-DF, 2015.
FRUTOS: "Na arvore da minha vida, quero colher bons frutos".

Copa: Quero poder trabalhar e aproveitar mais minha vida, administrando minha própria empresa.

Tronco: Quero conseguir terminar meus estudos do Ensino Médio mas não só terminar como aprender também, para que mais tarde eu possa pensar em fazer faculdade e ter mais oportunidades de trabalho.

Raiz: na minha familia em essencial minha rainha "mainha", muita fé em Deus, determinação, paz e saúde para seguir em frente na minha caminhada da vida.

A partir da árvore da vida do aluno é possível interpretar da sua argumentação que ele concebe a família como o lugar essencial para a realização dos valores para a vida em sociedade, e também um lugar privilegiado para se construir laços fervorosos de amor, saúde e paz.

Pode-se perceber, a partir da narrativa do aluno, que a sobrevivência familiar é uma preocupação, bem como questões como educação e escolha profissional aparecem como indícios de perspectivas essenciais para melhorar os padrões e assegurar a resolução de problemas no interior da família.

É possível interpretar, a partir das questões relacionadas aos sonhos e expectativas quanto ao futuro, uma forte concentração de positividade, pois concentra-se na ideia de ampliar o universo financeiro para sustentar as possibilidades de mudança no universo familiar. 
A narrativa do aluno P-Oito nos remete a uma entrevista do pesquisador da cultura visual, Raimundo Martins na TV Escola ${ }^{35}$ - Salto para o Futuro em 2011, com o tema: imagens, identidade e subjetividade, na qual Martins enfoca a quantidade de imagens que um adulto está submetido diariamente: imagens de outdoor, celular, anúncios publicitários e do computador. Assim, as imagens se enredam e produzem significados e resignificados.

A seguir, imagens e mensagens enviadas pelo aluno por meio do aplicativo do WhatsApp, figuras 28, 29, 30 e 31 .

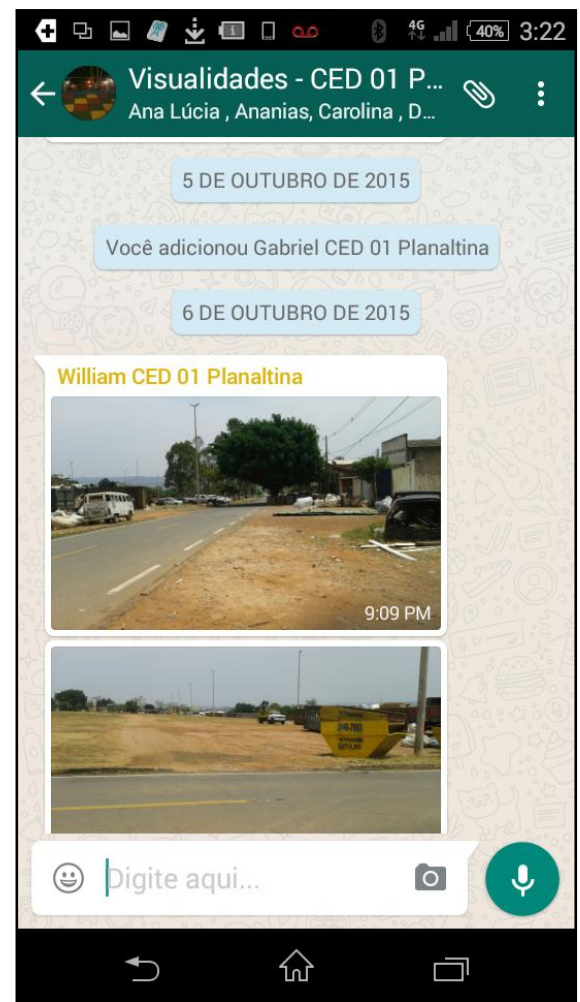

Figura 28. Mensagem do WhatsApp - aluno P-Oito. CED 01 de Planaltina-DF, 2015.

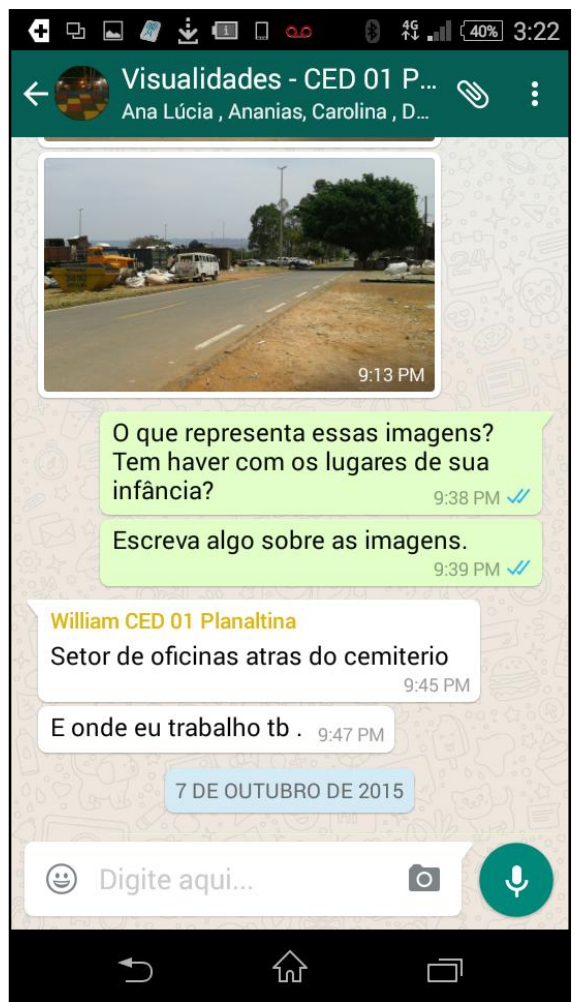

Figura 29. Mensagem do WhatsApp - aluno P-Oito. CED 01 de Planaltina-DF, 2015. 


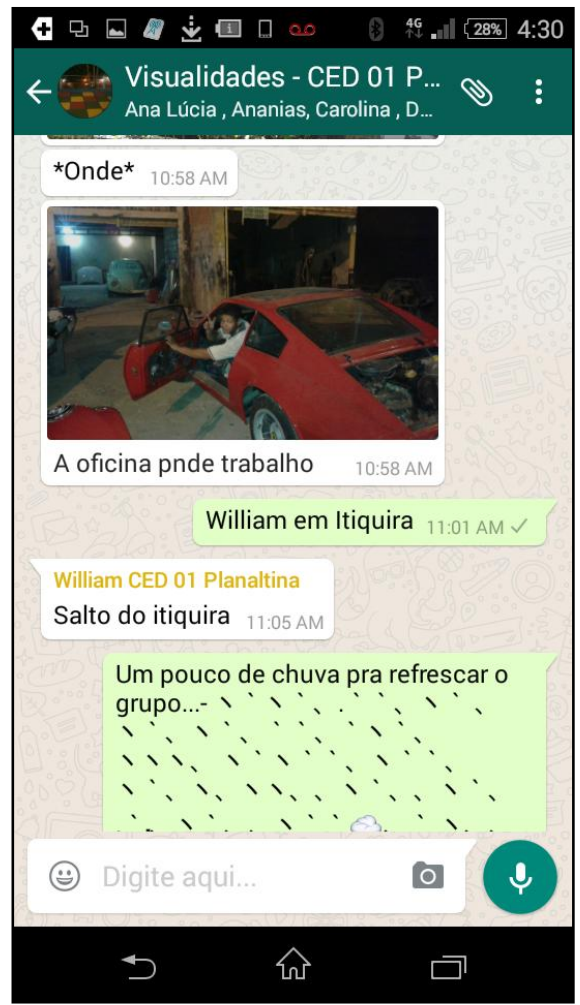

Figura 30. Mensagem do WhatsApp - aluno P-Oito. CED 01 de Planaltina-DF, 2015.

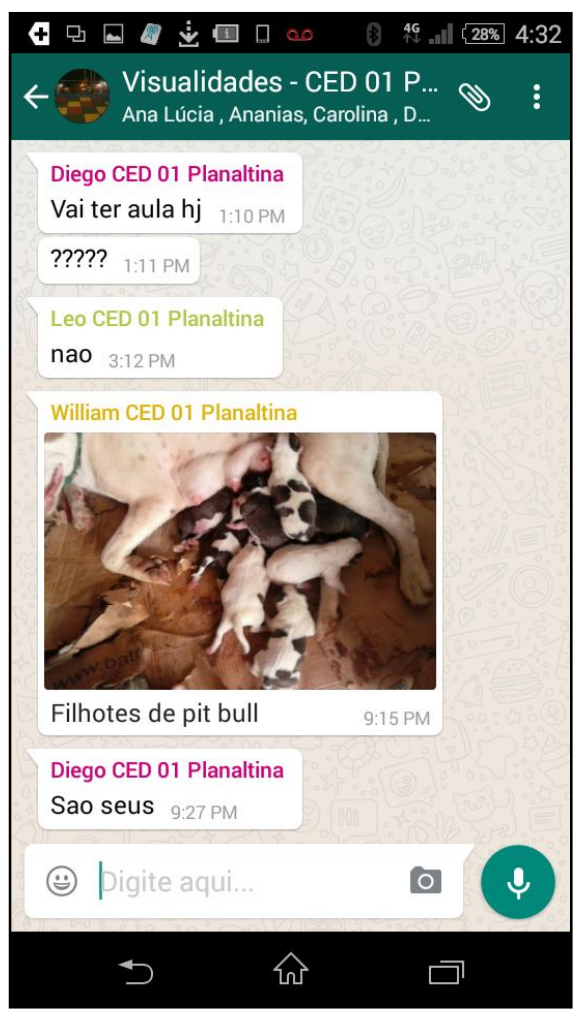

Figura 31. Mensagem do WhatsApp - aluno P-Oito. CED 01 de Planaltina-DF, 2015.

A visão da cidade de Planaltina relatada pelas imagens do aluno nos leva a perceber a convivência simultânea de elementos urbanos e rurais, ressaltando a alteração da paisagem com a chegada da seca. Quando o asfalto rompe o cerrado, ele insiste em aparecer desnudo e empoeirado, indícios do período da seca, quando o fluxo de chuvas diminui, as árvores como ipês começam a florescer, a poeira vermelha começa a levantar e a umidade do ar a baixar, trazendo as queimadas, que nessa época do ano são comuns. De agosto a setembro a cidade fica tomada por uma névoa seca, os problemas respiratórios, principalmente em crianças e idosos, são frequentes. É o clima seco: muito quente durante o dia e frio à noite.

As narrativas enviadas pelo aluno fornecem indícios para ajudar a repensar os processos de ensino e aprendizagem da Educação de Jovens e Adultos vivenciados nos estabelecimentos de ensino público do Distrito Federal. Nesse aspecto, a cultura visual se torna fundamental, como observa Tourinho e Martins (2010, p. 37), o poder da imagem sobre a imaginação das pessoas, influencia identidades individuais e coletivas, posições de sujeitos, modos de ver, pensar, agir e, consequentemente, a produção e interpretação de significados. 


\subsubsection{Narrativa Visual - Aluno P-Sete}

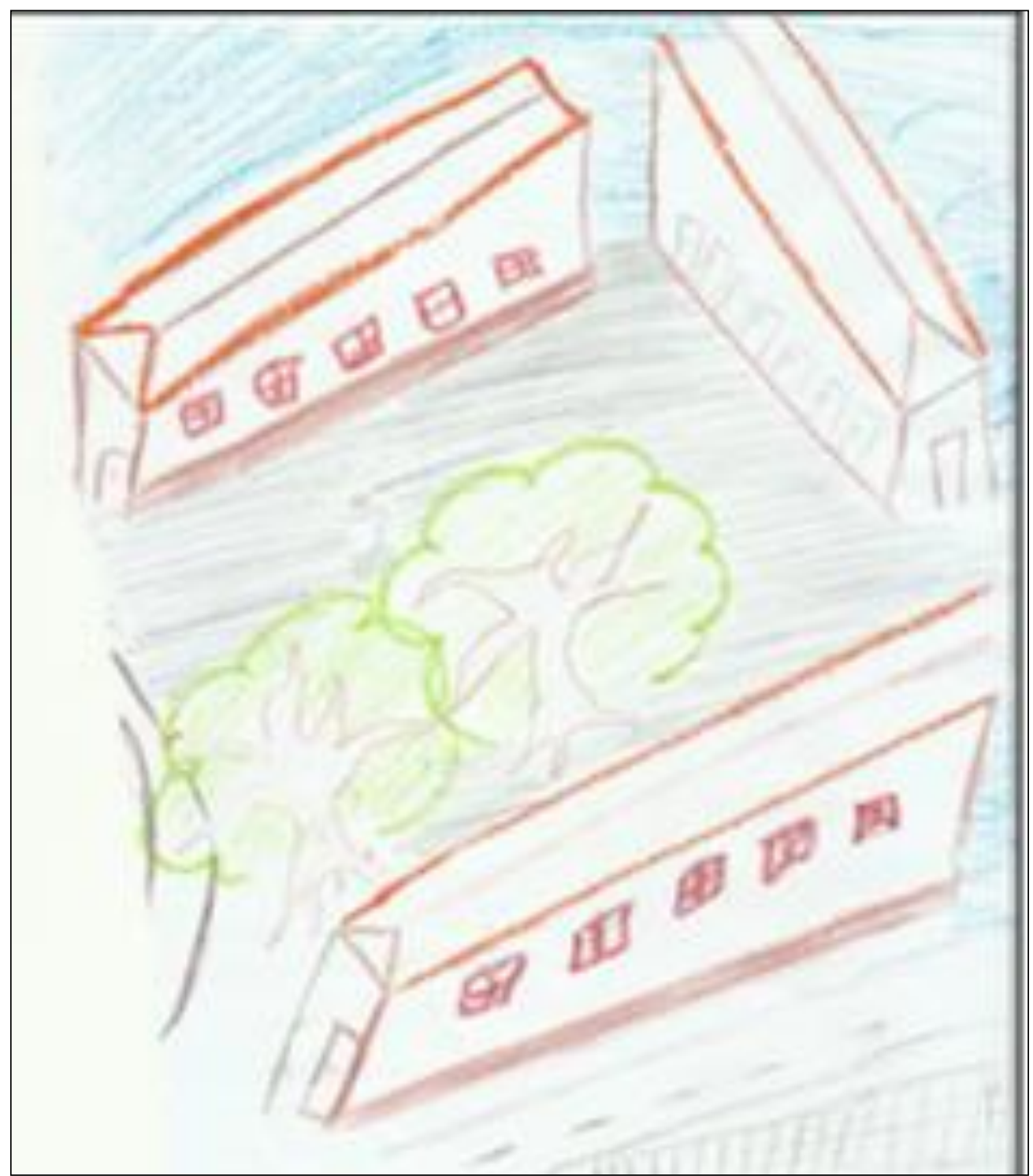

Figura 32. Lugares de lembrar a infância - aluno P-Sete. CED 01 de Planaltina-DF, 2015.

A figura 32 apresenta uma imagem de três prédios que dividem o espaço com o azul do céu e o tom enegrecido do chão. Os prédios, em tons amarronzados, possuem diversas janelas, sugerindo ser uma habitação coletiva. No centro da imagem, entre os três edifícios, aparecem duas árvores, sem frutos, pássaros e principalmente sem crianças. À direita do terceiro prédio, a imagem sugere um asfalto.

Nessa narrativa acerca da infância o aluno deixa transparecer espaços fechados e restritos, sugerindo a convivência de diversos moradores dos prédios com um único espaço destinados às brincadeiras de rua. 
A imagem sugere também, que a infância do aluno não foi na zona rural de Planaltina, por não apresentar paisagens com elementos do meio natural: solo, clima, declividade do relevo, presença de água e vegetação. A população vive dispersa em pequenos sítios. Já no meio urbano a população se concentra num espaço restrito, como o apresentado pelo aluno.

A imagem também nos faz lembrar que era comum nas cidades brasileiras, principalmente no interior, as crianças brincarem e jogarem na frente de suas casas, nas calçadas ou nas praças e ruas. Com a urbanização das cidades, a rua e a calçada deixaram de ser um ambiente de divertimento infantil.

A urbanização começou no Brasil quando a indústria passou a tornar-se o setor mais importante da economia nacional, marcando a passagem de uma economia agrárioexportadora para uma economia urbano industrial. A imagem retratada pelo aluno remete ao problema de moradia das cidades brasileiras, fazendo multiplicar as favelas, cortiços e demais habitações precárias.

A narrativa do aluno, entre outras deduções, remete ao fato de que o espaço interno dos apartamentos tornou-se mais atraente que as ruas, uma vez que o avanço tecnológico e as mídias têm provocado profundas mudanças nas relações humanas e no conceito de criança. A criança contemporânea convive simultaneamente com uma infinidade de informações e equipamentos eletrônicos, o que têm modificado as formas de brincar, sendo as brincadeiras e brinquedos tradicionais substituídas pelos jogos eletrônicos.

A cultura visual, como campo transdisciplinar de estudos, procura compreender como os artefatos cotidianos são capazes de ensinar e transmitir saberes. Nascimento (2010), por exemplo, busca promover discussões de cunho pedagógico a partir do universo televisivo, para entender as interpretações que as crianças fazem do que assistem na televisão.

Nesta mesma perspectiva, Tourinho e Martins (2011, p. 51) elegem como ideal para pensar as construções simbólicas, as imagens produzidas pelos jogos eletrônicos e propõem a necessidade de preparar os professores para analisar e interpretar imagens, artefatos artísticos e tecnológicos cotidianos, para ajudar os alunos a compreender e desenvolver uma atitude crítica em relação às imagens midiáticas.

Em seguida, o mesmo aluno reproduz a sua visão acerca da cidade, figura 33. A imagem feita com a caneta esferográfica preta, lembrando o tipo tinta nanquim (material muito usado para a escrita, o desenho e a pintura), predominando a mesma ideia da imagem anterior: prédios com pouca estética, sugerindo a aglomeração de moradores e a insistência do asfalto bem rente às moradias. 


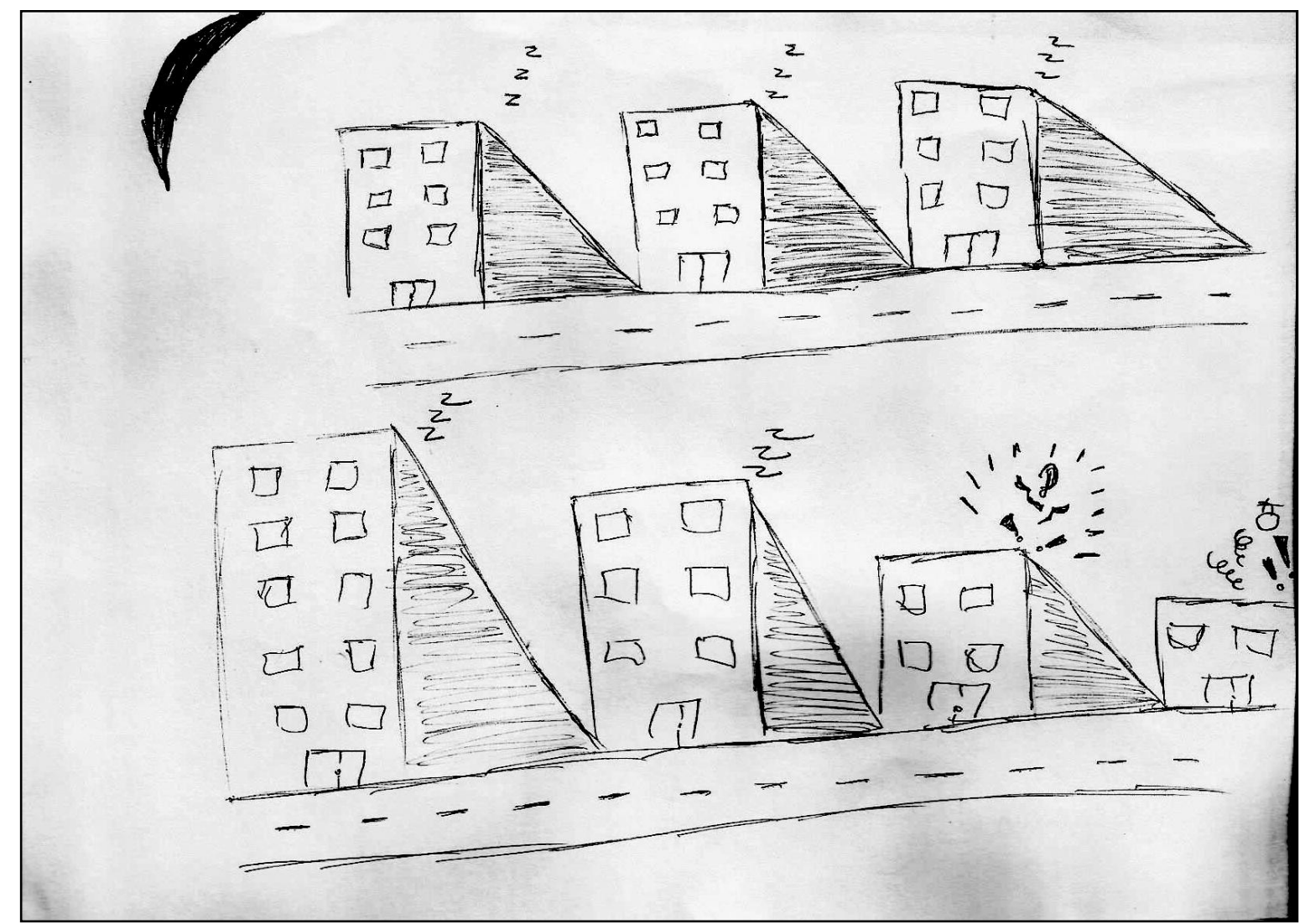

Figura 33. Lugares de lembrar a cidade e sua inserção - aluno P-Sete. CED 01 de Planaltina -DF, 2015.

Os símbolos presentes na narrativa são utilizados em diversos desenhos animados e filmes (a lua, a letra $\mathrm{Z}$ significando ronco e sono, e ênfases nos símbolos de exclamação e interrogação referindo-se ao barulho e os xingamentos) são indícios de que é noite alta: todos dormem, mas alguém faz muito barulho e acorda outro que não gosta de ser acordado.

O desenho alude aos problemas ambientais dos grandes centros urbanos, dos quais o barulho urbano, que consiste na perturbação do sossego das pessoas, na poluição sonora, como por exemplo, música alta, barulhos de animais, gritaria, soltura de fogos de artifício, ruídos provocados por equipamentos, buzina e alarme de veículo automotor, obras de construção e de reforma e indústria ruidosa, constituem situações que incomodam e desrespeitam o direito de todos em partilhar o mesmo ambiente.

Sobre os seus sonhos e perspectivas futuras, figura 34 , o aluno verbaliza: 


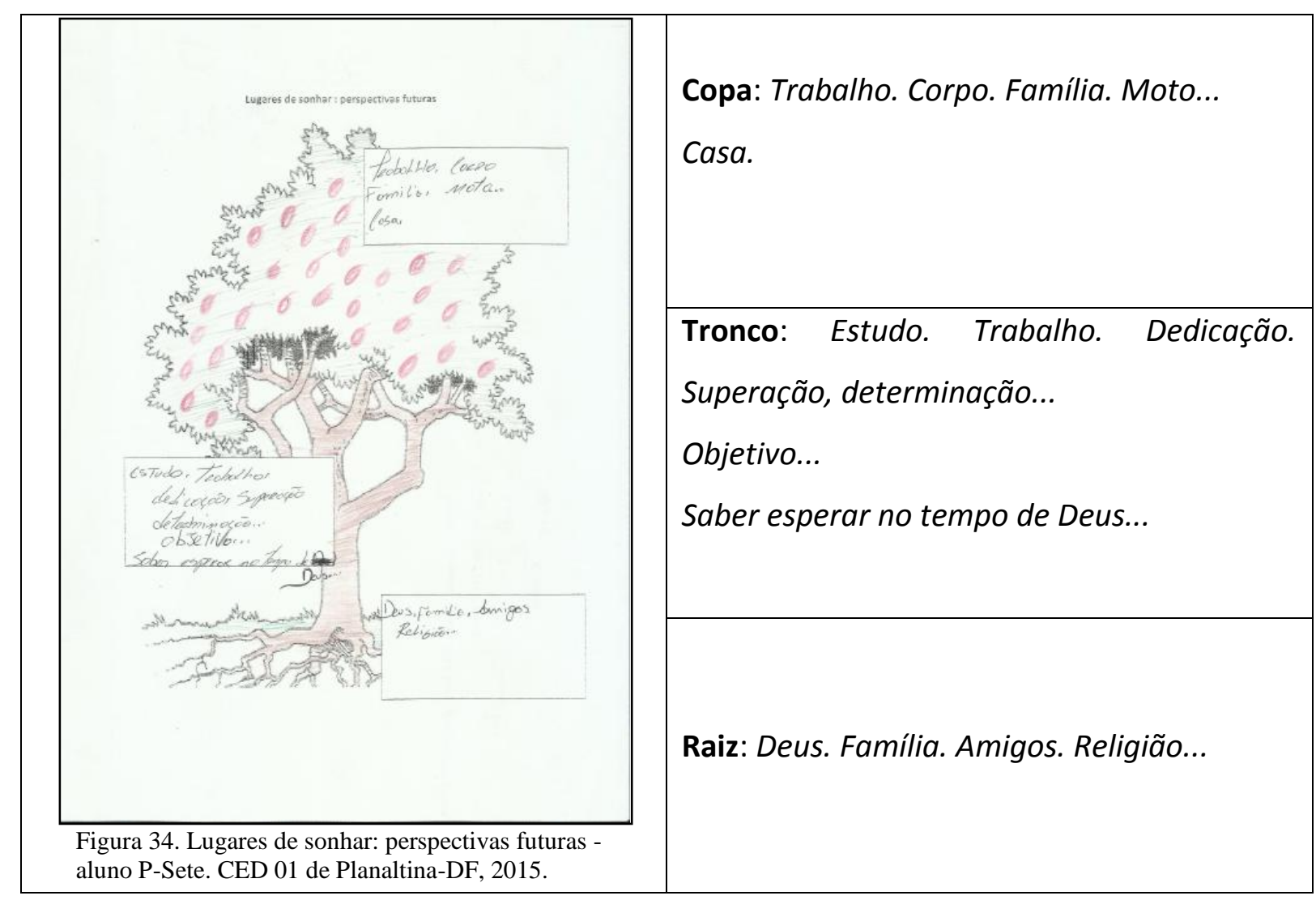

Em relação às perspectivas futuras podemos interpretar que a afirmação do aluno traz influências das visualidades e do discurso do consumo do capitalismo na orientação dos desejos e sonhos. Para o aluno, a conquista da moto e da casa se dá pelo trabalho. Também induz à reflexão sobre as transformações no mundo do trabalho a partir da globalização do capitalismo, facilitada pela incorporação da microeletrônica na vida produtiva.

A família aparece na copa e na raiz da árvore da vida do aluno. O texto verbal sinaliza que a família constitui para o aluno a base da sociedade, contribuindo decisivamente para o aprendizado do amor, da ética e do respeito ao outro.

Outro tema recorrente para o aluno é a religião, que ocupa um espaço importante e indissociável. O que nos induz a pensar que, para o aluno, a religião traz benefícios compatíveis com a racionalidade sadia de uma sociedade.

As mensagens de WhatsApp enviadas pelo aluno, figuras 35, 36, 37, 38, 39, 40, 41, 42, 43 e 44 expostas nas paginas de números 100 a 102, reforçam a sua religião de denominação evangélica, que ficam evidentes nas mensagens de oração e na letra da música.

O aluno também levanta a questão do problema da saúde no Distrito Federal, com a péssima oferta de serviços à população. A mensagem do aluno nos remete aos estudos de Singer (1988) sobre a saúde pública no Brasil, quando aponta que a crise generalizada da 
saúde depende diretamente da evolução, em função do desenvolvimento das forças produtivas nas relações de produção, que condicionam genericamente as contradições sociais, responsáveis pela gênese de estados mórbidos como decorrência da incapacidade para prevenir, suprimir e controlar a necessidade de aumento dos gastos com saúde pública e, o crescimento do número de necessitados desse atendimento. $\mathrm{O}$ que significa que a doença não é considerada como resultado, e sim uma contradição entre o homem e o meio natural, mas também, e necessariamente, uma contradição entre os indivíduos que mantém a discrepância entre a produção de riqueza e sua distribuição, colaborando com um alto índice inaceitável de desenvolvimento humano, especialmente em regiões específicas do Brasil. A desigualdade permanece uma constante, independentemente da região.

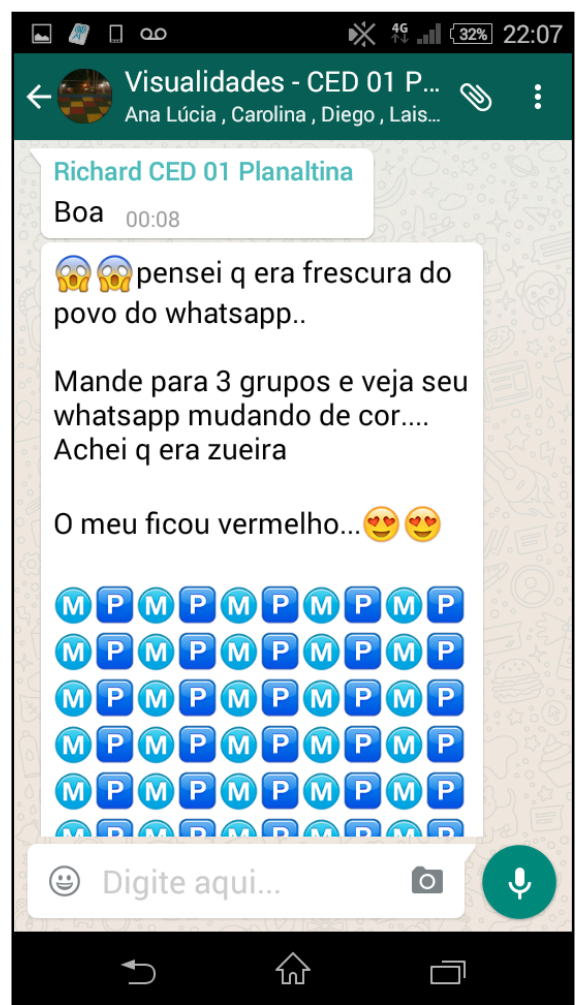

Figura 35. Mensagem do WhatsApp - aluno P-Sete. CED 01 de Planaltina-DF, 2015.

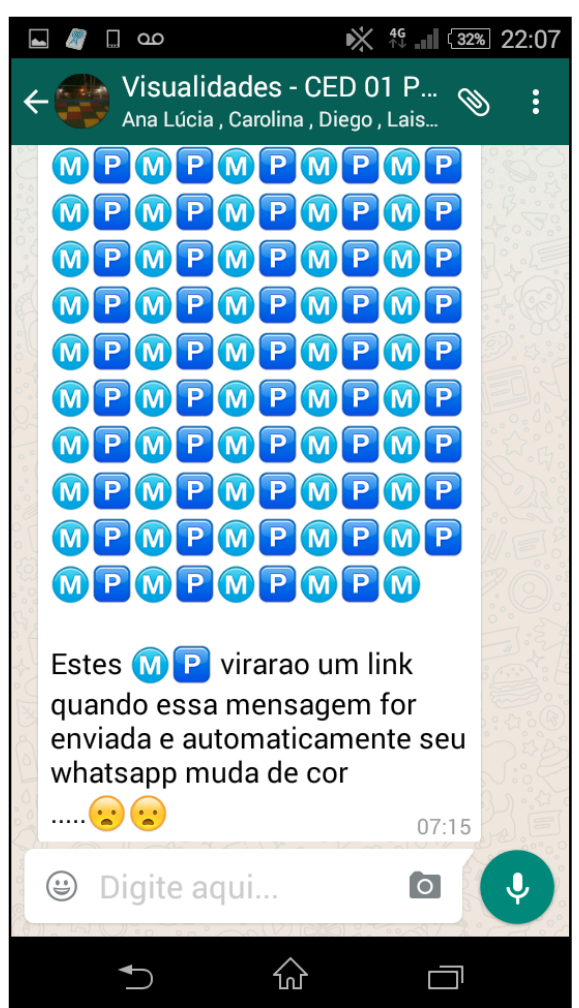

Figura 36. Mensagem do WhatsApp - aluno P-Sete. CED 01 de Planaltina-DF, 2015 


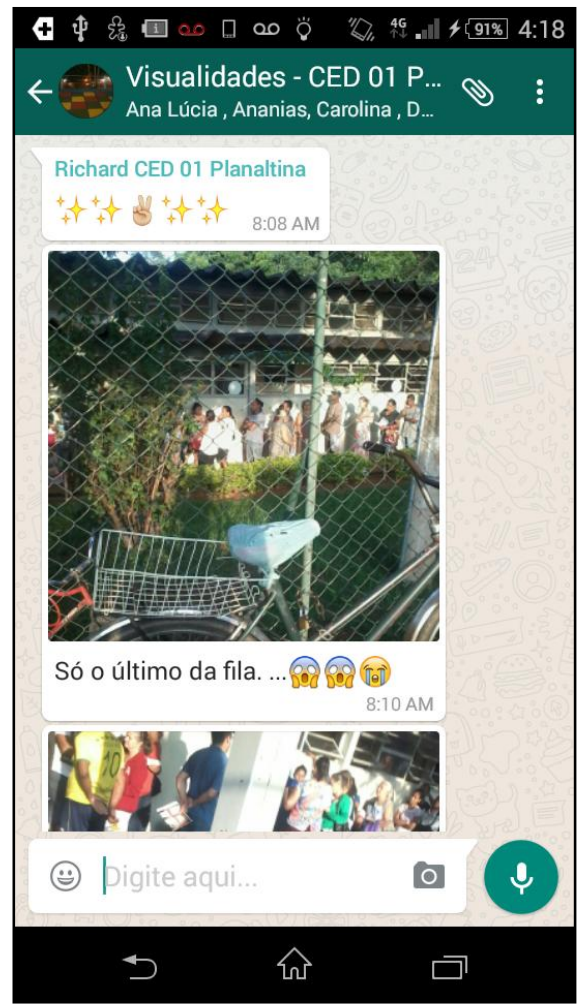

Figura 37. Mensagem do WhatsApp - aluno P-Sete. CED 01 de Planaltina-DF, 2015.

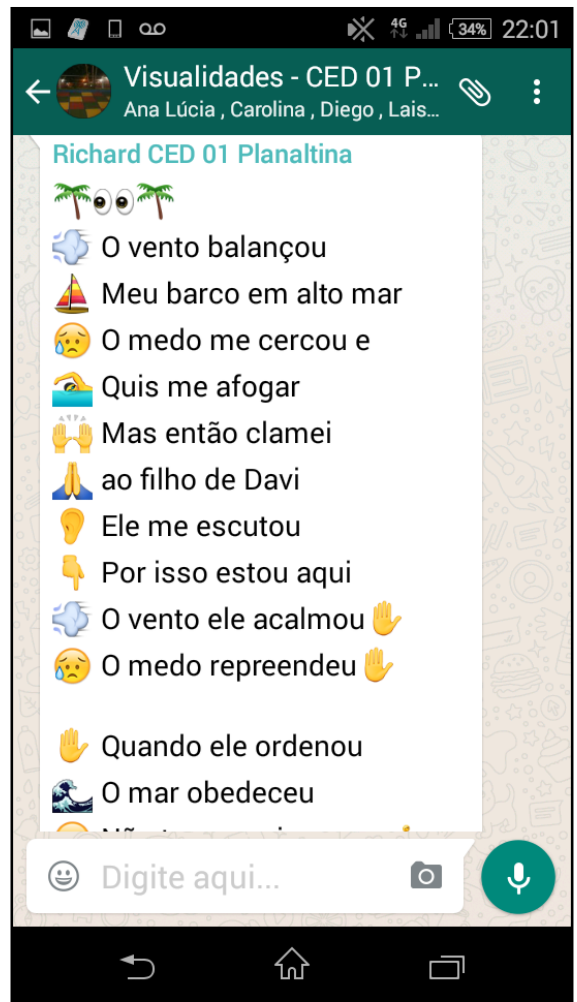

Figura 39. Mensagem do WhatsApp - aluno P-Sete. CED 01 de Planaltina-DF, 2015.

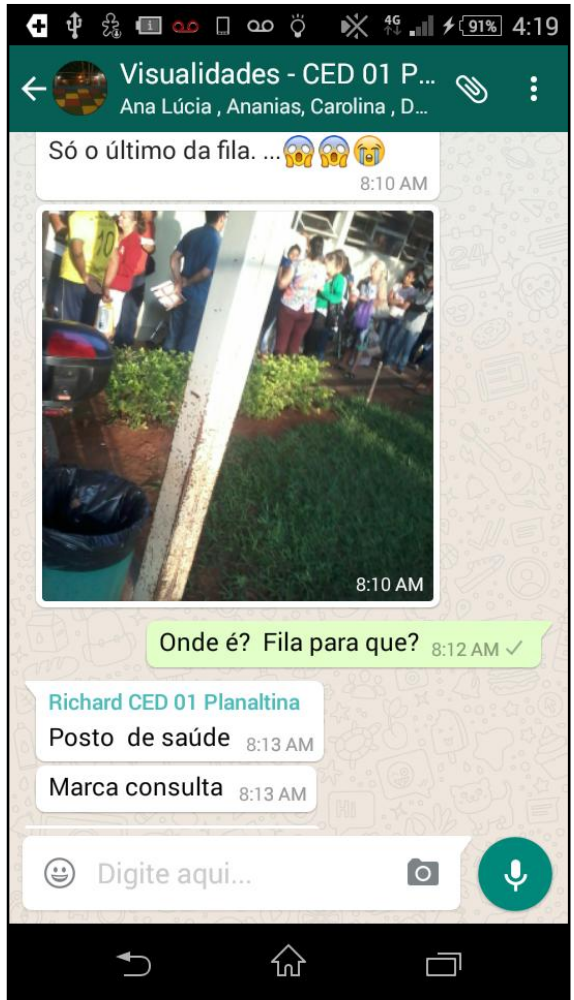

Figura 38. Mensagem do WhatsApp - aluno P-Sete. CED 01 de Planaltina-DF, 2015.

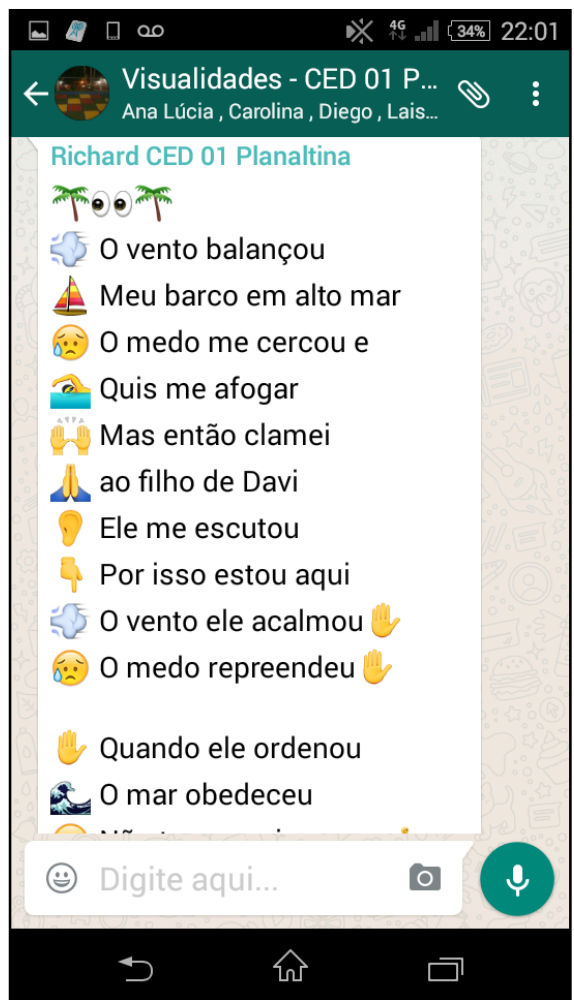

Figura 40. Mensagem do WhatsApp - aluno P-Sete. CED 01 de Planaltina-DF, 2015. 


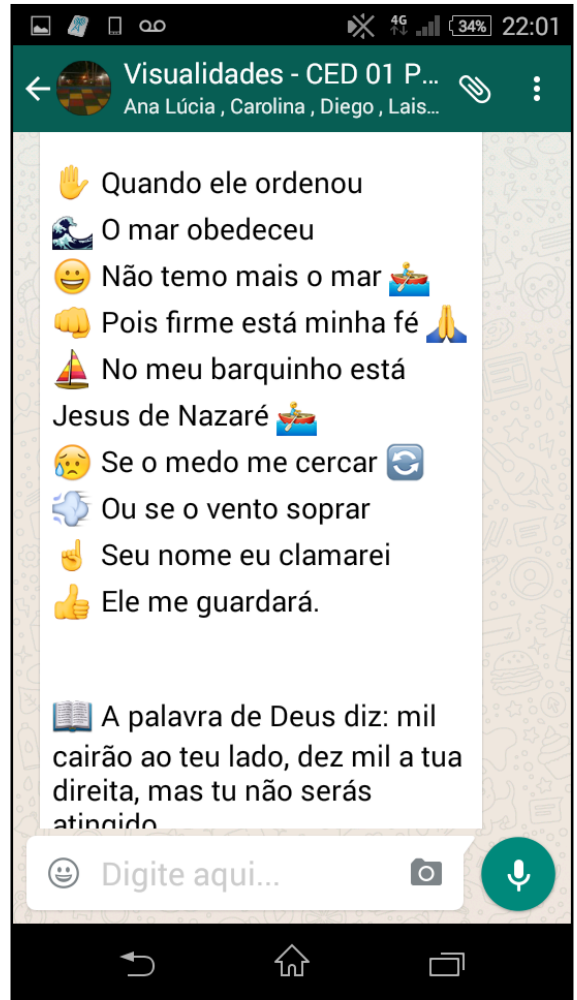

Figura 41. Mensagem do WhatsApp - aluno P-Sete. CED 01 de Planaltina-DF, 2015.

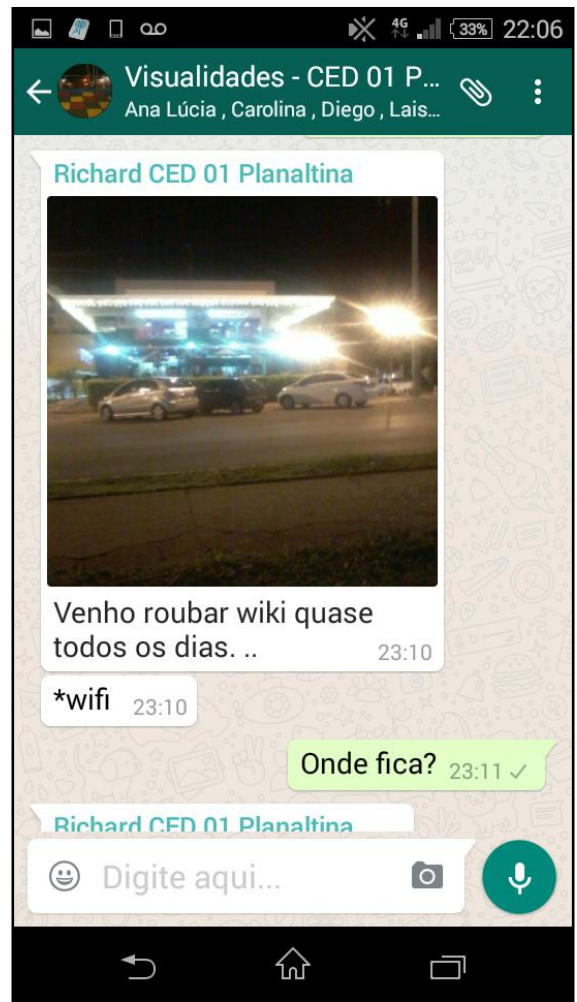

Figura 43. Mensagem do WhatsApp - aluno P-Sete. CED 01 de Planaltina-DF, 2015

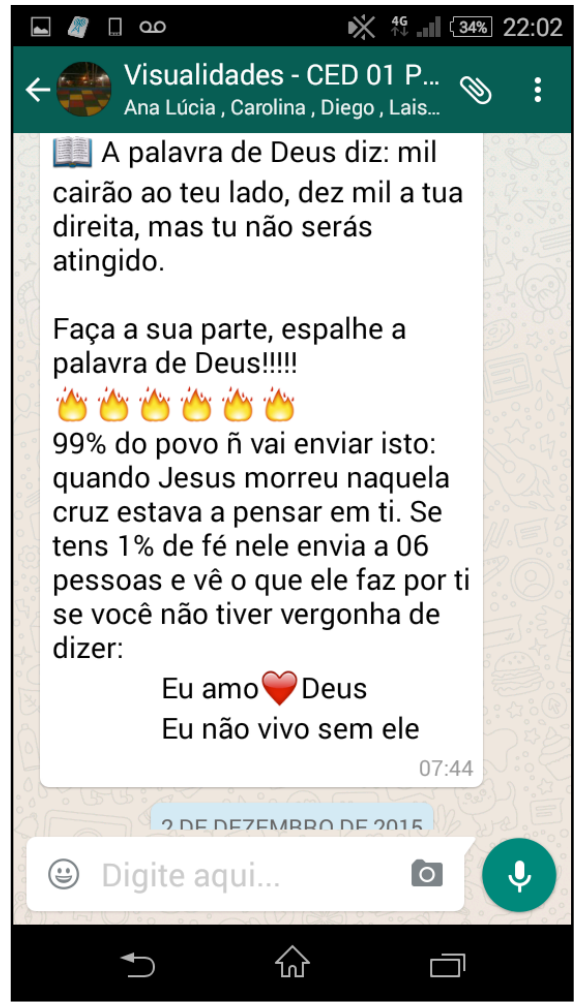

Figura 42. Mensagem do WhatsApp - aluno P-Sete. CED 01 de Planaltina-DF, 2015.

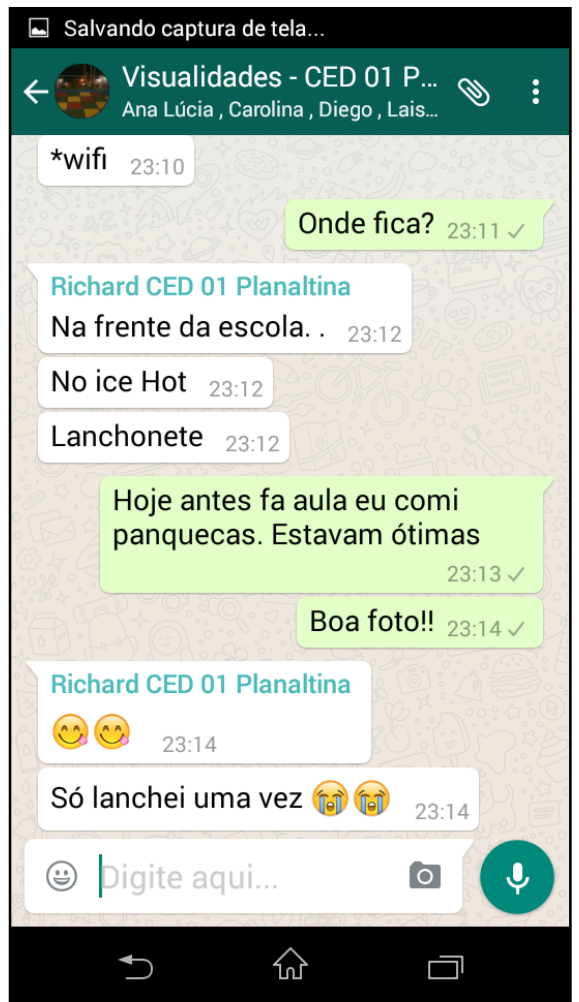

Figura 44. Mensagem do WhatsApp - aluno P-Sete. CED 01 de Planaltina-DF, 2015.

Sobre as narrativas visuais do aluno pode-se interpretar que se trata de um jovem que parece pertencer a uma família de poucos recursos econômicos. Isso é dedutível pela 
necessidade de enfrentar uma fila imensa para acesso ao sistema público de saúde, bem como pelo seu desejo de adquirir moto e casa e pela necessidade de "roubar wifi quase todos os dias", sendo um indicativo de que o consumismo ao mesmo tempo que exclui, também orienta as perspectivas de futuro dos jovens.

Também nos faz lembrar que durante muitos anos, a rua foi o lugar de brincadeiras e jogos, mas hoje ela se transformou em lugar de embates e brigas. Para os jovens urbanos o acesso ao lazer e ao consumo é restrito àqueles que podem comprar, como evidência o fato do aluno ter lanchado apenas uma única vez na lanchonete em frente à escola, onde ele vai captar sinais da internet.

\subsubsection{Narrativa Visual - Aluno P-Dois}

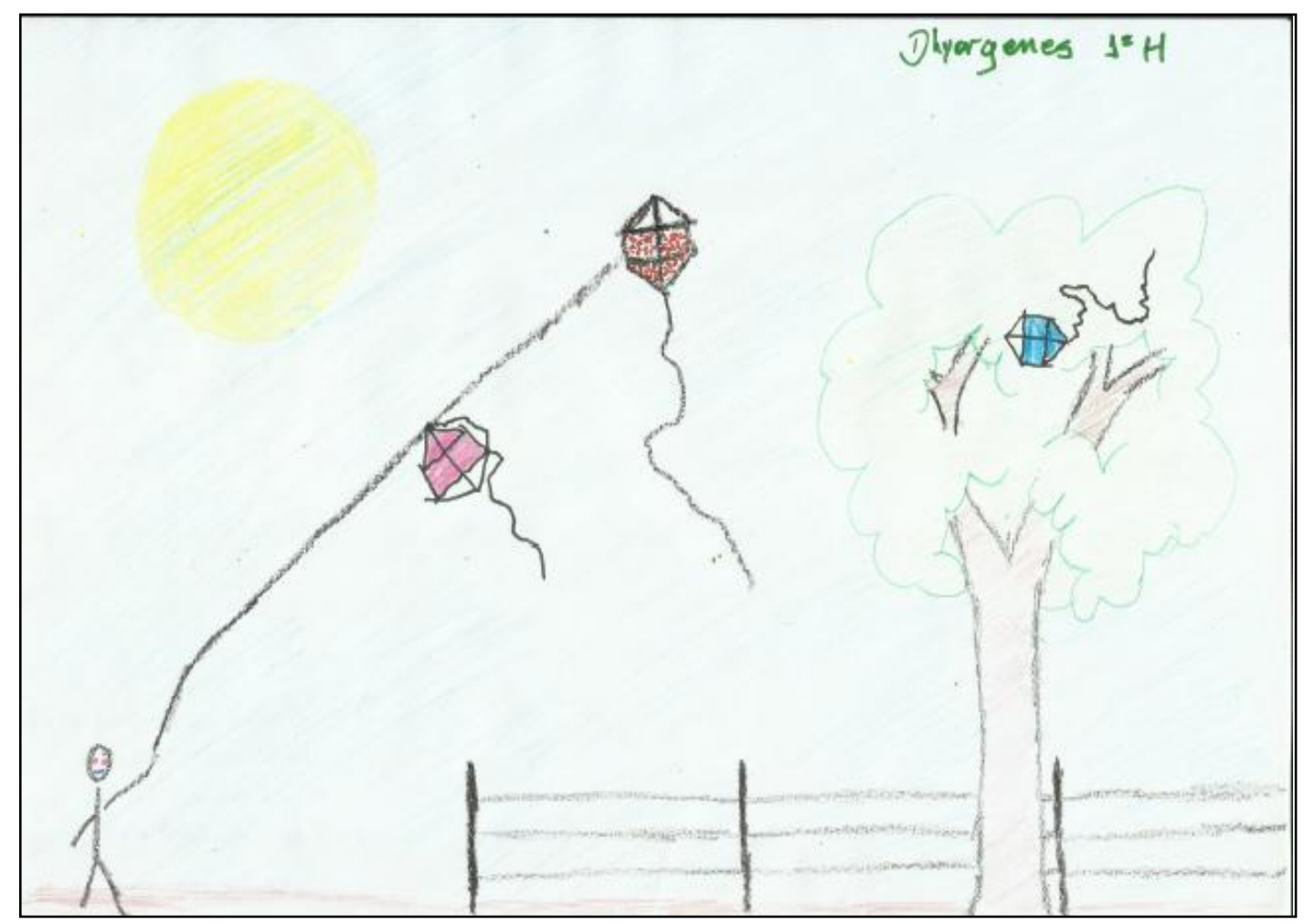

Figura 45. Lugares de lembrar a infância - aluno P-Dois. CED 01 de Planaltina-DF, 2015.

Nesta narrativa visual, figura 45, o aluno traz como lembrança do seu universo infantil a brincadeira em um dia de sol brilhante e vento propício para a disputa de pipas. Uma das pipas se enroscou na árvore, outras duas parece que estão sendo disputadas. A criança está diante de uma cerca que não limita o seu espaço de brincadeira.

A imagem nos remete ao estudo de Rodrigues (2009) ao discorrer sobre a importância do brincar na educação da criança, observa que o brinquedo possui uma dimensão histórica e 
cultural, já que são representações criadas pela sociedade para identificar coisas ou objetos. A sua origem remonta o século XI quando ainda havia pequenas miniaturas de objetos utilizados pelos adultos, que serviam como enfeites de estantes ou eram depositados nos túmulos dos entes falecidos como uma forma de amuleto, destinados a fins religiosos. A autora afirma que na Idade Média, as réplicas foram dando lugar ao brinquedo, já que a criança ao manusear esses objetos descobria o mundo da brincadeira. Para Porto (2005, p. 172, apud Rodrigues 2009), "eram objetos de culto doméstico ou funerário, ex-votos de devotos e de peregrinos, ou seja, objetos familiares que eram reduzidos e depositados nos túmulos”. Dessa forma, os brinquedos surgiram das mãos dos entalhadores de madeira, dos produtores de vela, dos caldeireiros e artesãos dentre outros.

Essa mesma ideia é desenvolvida por Benjamin (1994, p. 90) ao afirmar que os brinquedos, em seus primórdios, "não foram invenções de fabricantes especializados, surgiram, originalmente das oficinas de entalhadores em madeira e fundidores de estanho e etc". Na segunda metade do século XIX, a industrialização de brinquedos se expandiu e a madeira começou a perder lugar para outros tipos de materiais como o metal, vidro, papel e alabastro, juntamente com a separação das brincadeiras que antes englobavam adultos e crianças.

Sobre a brincadeira de pipa, trazida pelo aluno, Kishimoto (1993) alega que alguns brinquedos e brincadeiras têm sua origem em algum acontecimento da época, por exemplo, a pipa, era utilizada pelos adultos para fins de prática de estratégia militar. Em sua pesquisa observa que, “o uso da pipa, em estratégia militar, provém da época do imperador Wou-ti, da dinastia dos Liang, quando ela servia para comunicar aos aliados a posição e o pedido de ajuda".

Como observado anteriormente, os brinquedos e brincadeiras de rua foram substituídos por brinquedos e jogos eletrônicos. Kishimoto (1993) reconhece que o avanço tecnológico ameaça esse tipo de brincadeira que se torna desconhecida da criança.

A narrativa do aluno acerca da cidade, figura 46, mostra o momento de um assalto com disparo de arma de fogo. A imagem com traços negros e azuis apresenta um espaço comercial com prédios de diferentes tamanhos, o poste de luz e um carro que parece estar em fuga. Tal dedução é feita a partir da observação da fumaça do escapamento do carro. Atrás da cena, são colocados em evidência dois prédios: Banco Itaú ${ }^{36}$ e McDonald's s7 ${ }^{37}$ considerados

\footnotetext{
${ }^{36}$ O Itaú surgiu em 1988, em associação entre os bancários Fernão Bracher e Antônio Beltran e o Creditanstalt, um banco austríaco.
} 
símbolos do capitalismo. Sabe-se que o fenômeno social da violência não é exclusivo da sociedade capitalista, entretanto nessas sociedades a violência assume a sua face mais perversa.

Estudos realizados por Charréu (2007) apontam a existência de uma violência institucionalizada e espetacularizada cotidianamente pela televisão. Essas imagens veiculadas diariamente nas mídias é o que podemos designar de "banalização do mal”38. Para o autor, "os jovens encontram-se imersos numa difusa e complexa cultura mediático-consumista, e esta cultura de contornos mal definidos é o lugar existencial absoluto onde vive a maior parte dos jovens (...) principais vítimas da violência” (Charréu, 2007, p. 192).

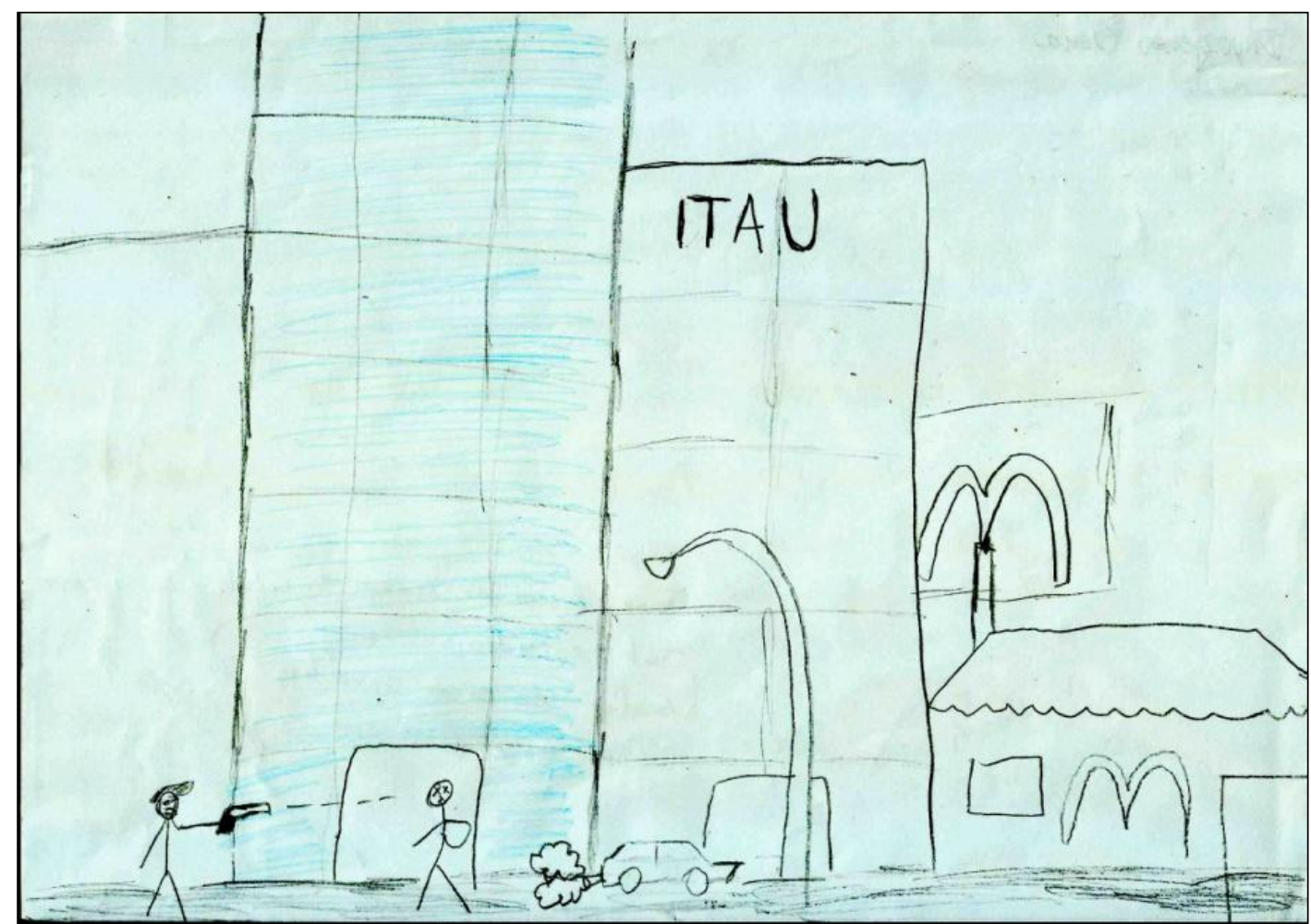

Figura 46. Lugares de lembrar a cidade e sua inserção - aluno P-Dois. CED 01 de Planaltina-DF, 2015.

37 Surgida em 1937 quando os irmãos Richard e Maurice abriram um modesto restaurante no Estado da Califórnia. Atualmente a marca MCDONALD'S se tornou a maior rede de alimentação rápida e um dos símbolos do capitalismo e do estilo de vida americano no mundo.

${ }^{38}$ Banalidade do mal é uma expressão criada pela filosofa alemã Hannah Arendt (1906-1975), quando em 1961, enviada pela revista The New Yorker, para acompanhar o julgamento do nazista Eichmann em Jerusalém, acusado de genocídio e crimes contra a humanidade durante a guerra. Para a filosofa a violência, quando atinge grupos sociais, é político e ocorre onde encontra espaço institucional. Ver ARENDT, Hannah. Eichmann em Jerusalém: um relato sobre a banalidade do mal. São Paulo: Companhia das Letras, 1999. 
A imagem sugere que a pessoa esteja saindo ou entrando no banco. Nela, o aluno expõe algumas das mazelas da cidade de Planaltina, remetendo aos altos índices de criminalidade.

Ela nos remete também ao estudo desenvolvido por Teixeira (2011), o qual reflete sobre a relação entre criminalidade e educação e constata que o abandono da escola aumenta a criminalidade na sociedade e, a violência na escola provoca baixo aprendizado entre os alunos. Utilizando modelos econométricos, o autor analisa o vínculo entre educação e criminalidade. Para isso, analisou o impacto da educação defasada e o abandono escolar sobre a criminalidade do ano posterior ao abandono, em todos os estados brasileiros, entre 2001 a 2005, bem como o efeito da violência sobre o desempenho escolar dos alunos do estado de São Paulo em 2007, chegando a conclusão de que a criminalidade aumentou em $51 \%$ em todos os estados devido à evasão escolar.

A narrativa do aluno mostra uma infância na qual predominavam as brincadeiras de rua, já aquela acerca da cidade retrata um espaço urbano em que a população está exposta à violência. Em relação aos seus sonhos e projetos futuros, figura 47 o aluno faz a seguinte narrativa:

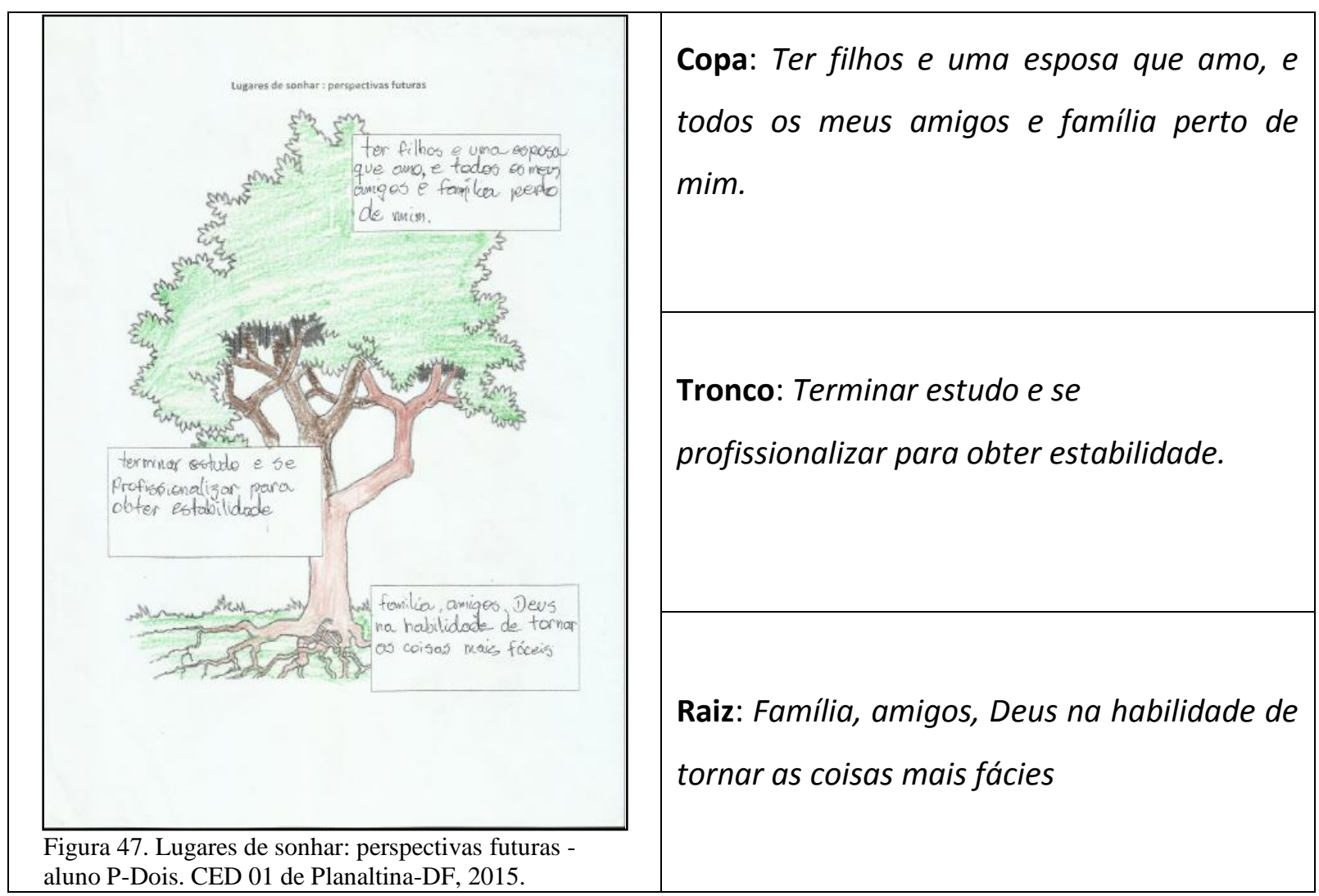


Como nas demais narrativas, nessa predomina a formação de uma família, estabilidade profissional e religião como elementos que perpassam a sua árvore da vida.

No seu sonho (copa) apresenta uma concepção do amor romântico, como valor cultural e base ideal para o casamento. O texto do aluno sugere que ele vê o relacionamento como fonte de realização afetiva e o cônjuge como o responsável pela sua felicidade, isto se torna evidente quando o aluno postula a associação entre o casamento e o amor.

Sua narrativa também sugere uma visão tradicional de que a constituição da família orienta-se por um modelo único e o casamento serve para se instalar na vida e satisfazer as necessidades de sobrevivência, sexuais e econômicas.

Ainda é evidente a ideia de que a educação propicia a realização profissional e estabilidade financeira, como sugere o aluno no tronco de sua árvore.

$\mathrm{Na}$ base da árvore repetem-se os mesmos elementos presentes na copa: família e amigos. O aluno também acrescenta Deus como o que torna possível todas as coisas, mantendo a mesma característica de religiosidade presente nas narrativas anteriores.

Nas suas mensagens de WhatsApp, figuras 48 e 49, traz informação sobre a greve dos professores ocorrida em 2015 e uma mensagem homofóbica.



Figura 48. Mensagem do WhatsApp - aluno P-Dois. CED 01 de Planaltina-DF, 2015.

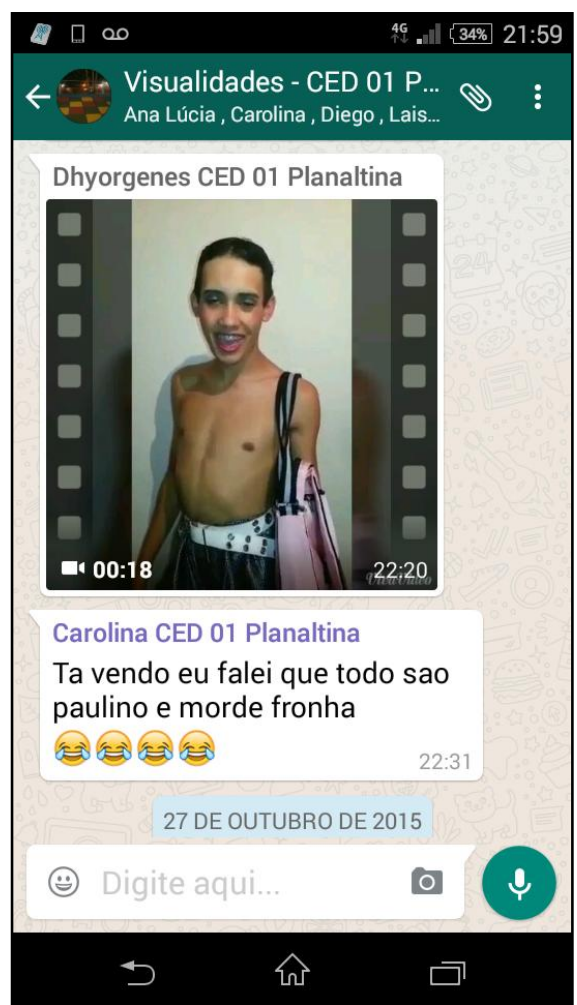

Figura 49. Mensagem do WhatsApp - aluno P-Dois. CED 01 de Planaltina-DF, 2015. 
Na primeira mensagem o texto alega que em plena Capital do Brasil, o governo não paga os salários dos servidores e retira direitos conquistados. Uma alusão ao não pagamento de reajustes salariais, o atraso nos pagamentos de benefícios como o $13^{\circ}$ salário e abono de férias.

A outra mensagem, com conteúdo homofóbico, denomina os torcedores do time São Paulo como "morde-fronha", palavra que designa, em alguns estados brasileiros, o homossexual. Uma nítida discriminação e violação aos direitos da população LGTB.

Além de aludir ao preconceito e à discriminação da população LGTB, a postagem do aluno remete à rivalidade entre os clubes de futebol e a violência das torcidas. Pode-se compreender da mensagem a existência de uma visão hegemônica sobre gênero implícita na própria imagem com a identificação de um código prévio entre o emissor e o receptor da mensagem.

Em seu estudo sobre as questões da visualidade de gênero e sexualidade, Dias (2011) observa que elas sempre estiveram interligados com temas de raça, classe, comunidade, deficiência, identidade, idade, entre outros tópicos. Sugere, no espaço educativo, a adoção de novos enquadramentos conceituais sobre as noções de poder e conhecimento, para que sejam discutidas criticamente as questões de representação, para além da interpretação de significados hegemônicos.

A narrativa do aluno nos faz lembrar que o futebol é um dos principais fenômenos socioculturais contemporâneos, capaz de despertar paixão, emoção, empolgação, expectativa, frustração e outras subjetividades humanas. Sua gênese encontra-se na Inglaterra do século XIX, praticado apenas pela elite das cidades. A palavra sport é um termo importado da Inglaterra para designar jogos coletivos de passatempos.

A narrativa remete aos estudos de Elias e Dunning (1992) sobre os desportos em geral como competições e confrontos, que envolvem forças físicas, sem finalidades militares. Organizados a partir de regras que existem para diminuir os riscos de danos físicos, além de obrigar os adversários a terem determinados tipos de comportamentos, que exigem um autocontrole dos participantes: jogadores ou torcedores, regras que foram exportadas para outros países. Os autores exemplificam com as lutas de boxe que na Antiguidade eram realizadas em forma de duelo, em que um dos participantes chegava à morte. Com o passar dos tempos foram criadas as regras e os equipamentos, como luvas e protetores de pugilato obrigatórios na atualidade. Segundo os autores, com estas mudanças busca-se aumentar a competitividade e diminuir as manifestações violentas. 
Entretanto, a crescente ascensão da violência no futebol que extrapola os locais da competição, despertou a análise dos sociólogos Elias e Dunning (1992) que veem nessas manifestações uma explosão de uma juventude frustrada, tendo como principais responsáveis a ingestão exagerada de bebidas alcoólicas, visto que tal substância retira as inibições e aumenta a sensação de camaradagem entre os membros, gerando uma rígida separação entre quem é do grupo e quem não é. Fatos que facilitam a violência.

O futebol foi introduzido no Brasil em outubro de 1894, por Charles Miller - brasileiro filho de ingleses. No Brasil, o futebol foi reinventado, tornando-se um esporte popular e passando a representar uma das principais manifestações culturais brasileiras.

A ascensão das classes populares ao futebol não foi tão democrática como se costuma pensar. É bem conhecida a história do jogador do Fluminense Football Club, que, na segunda metade do século XX, passou pó de arroz no rosto para esconder a cor da pele.

É um fenômeno sociocultural e historicamente construído, como assinalado pelo antropólogo DaMatta (1982), tendo um papel importante na criação de uma identidade nacional e capaz de dramatizar as particularidades do convívio social brasileiro.

\subsubsection{Narrativa Visual - Aluno P-Três}

A narrativa, figura 50, em um fundo claro sobre um risco escuro mostra duas crianças com um taco na mão.

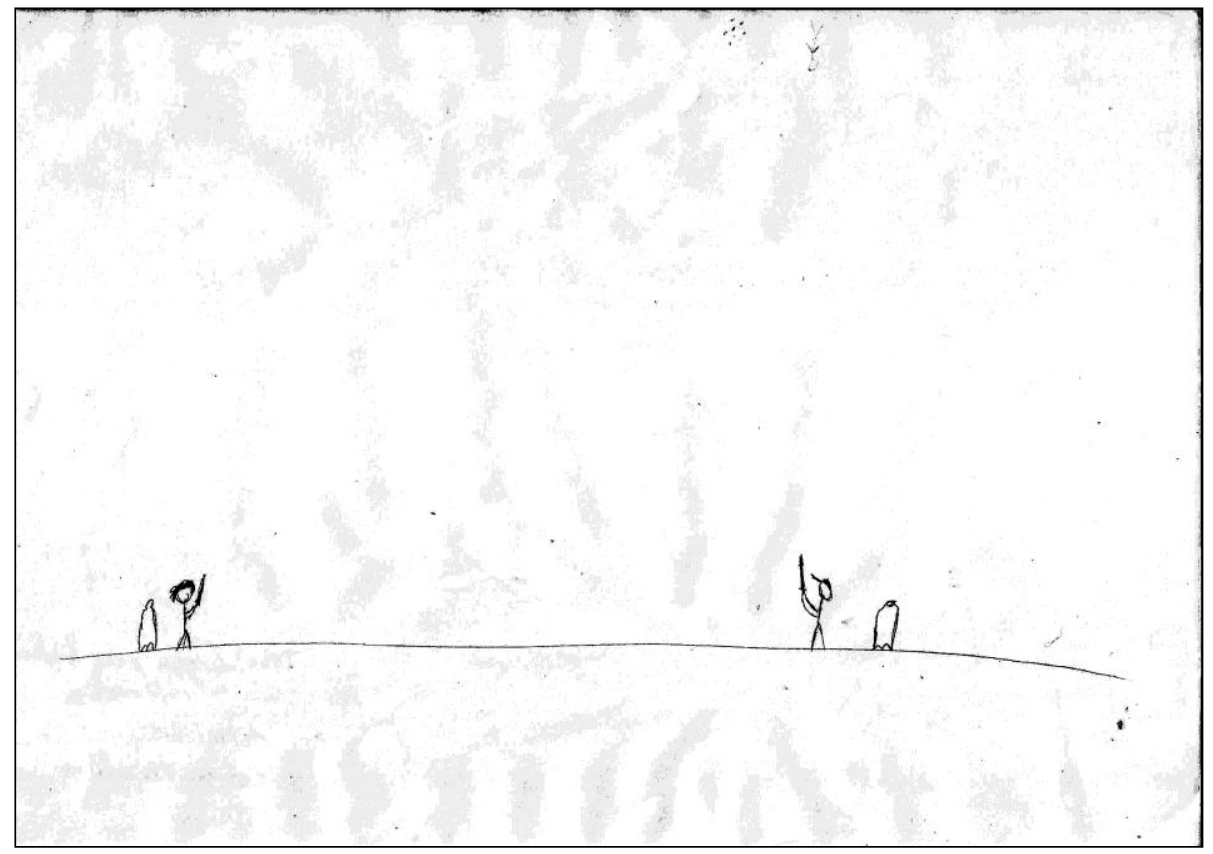

Figura 50. Lugares de lembrar a infância - aluno P-Três. CED 01 de Planaltina-DF, 2015. 
A imagem reproduz o jogo de taco ou bete, muito conhecido pelas crianças e adolescentes nos anos de 1980. Conhecido também como bete-ombro, bets e tacobol, esse jogo de rua tem várias versões para o seu surgimento. Uns dizem que foi criado por jangadeiros brasileiros no século XIX. Outros afirmam que "bete" derivou da palavra inglesa bet, muito utilizada nas partidas de críquete, na Inglaterra. Outra hipótese é que é uma derivação do beisebol.

O jogo é coletivo (exige uma dupla de cada lado) e tem como objetivo rebater a bola lançada pelo jogador adversário, que tenta derrubar uma lata ou garrafa no lado do time. Exige-se para isso: dois tacos de tamanho médio, dois alvos, que pode ser garrafa plástica, latas de refrigerante ou pedaços de madeira apoiados em forma de tripé, uma bola pequena de borracha (tênis ou frescobol) e giz para desenhar no chão; muitas vezes o risco é improvisado com um pedaço de carvão ou pedra. $\mathrm{O}$ jogo pode ser praticado em qualquer terreno como grama, campo, praia ou mesmo na rua sobre o asfalto.

Em sua narrativa acerca da cidade, figura 51, o aluno apresenta uma imagem com um céu, branco com tons de azul e cinza. Nesse céu, pássaros voam diante de um sol que reflete os seus raios. Alguns tons de azul e lilás delimitam o espaço entre o céu e a terra.

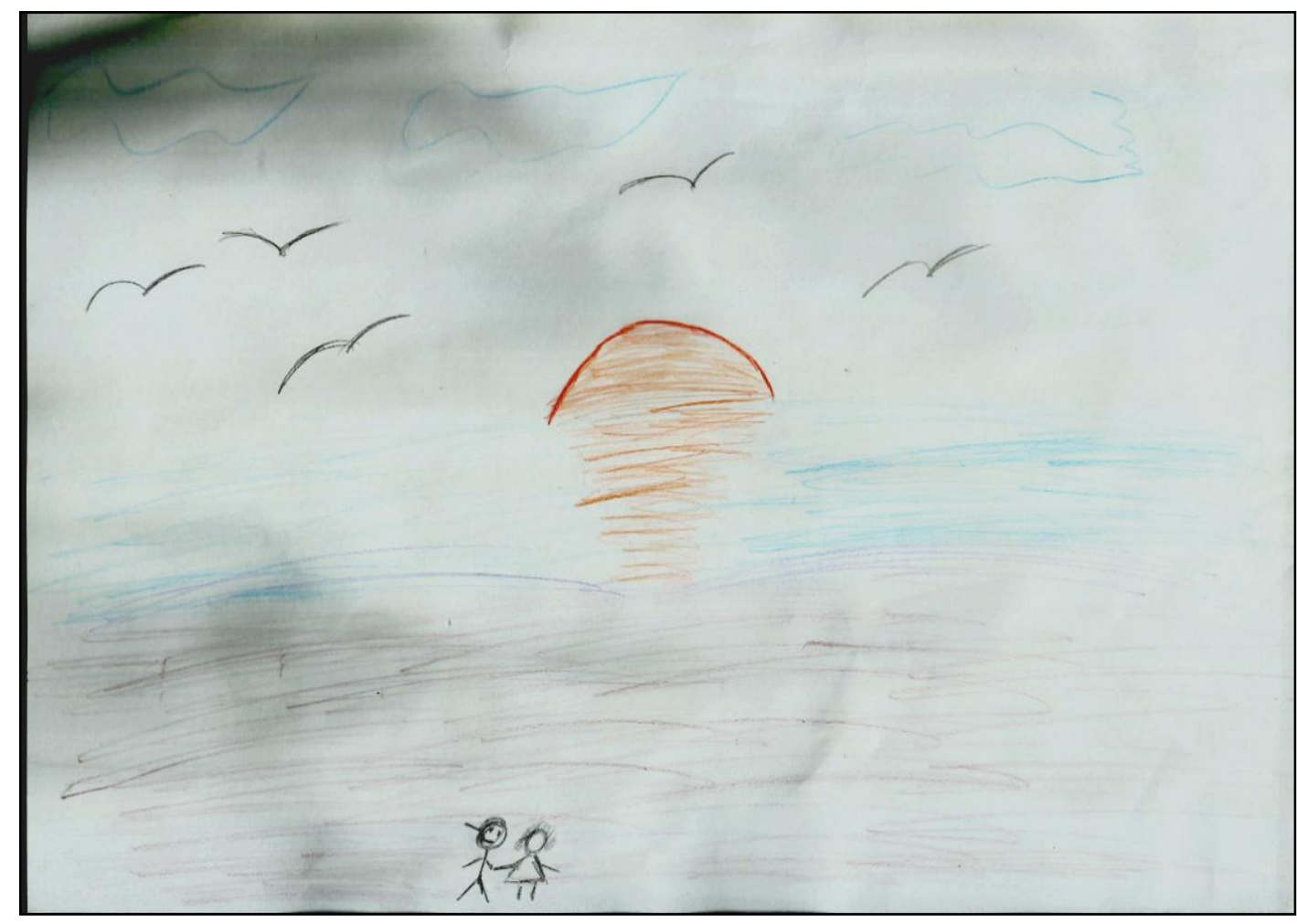

Figura 51. Lugares de lembrar a cidade e sua inserção - aluno P-Três. CED 01 de Planaltina-DF, 2015. 
Há duas pessoas de mãos dadas sugerindo dois jovens, um rapaz e uma moça, em um estado de amor, caracterizado pela sua força transformadora que expande a individualidade dos namorados, numa fusão unificadora das aspirações, pensamentos e anseios de jovens apaixonados.

A expressão imagética do aluno nos remete ao estudo realizado por Cunha (2001), no qual observa que o desenvolvimento da linguagem plástica, na prática artística na escola, há uma padronização de formas estereotipadas: a casinha, a árvore com maçãs, as nuvens azuis, o sol, as flores, a figura humana de palito. O resultado, segundo a autora, é que as crianças desde cedo deixam de construir suas próprias linguagens, passando a reproduzir e consumir as imagens impostas pelos adultos. Isto é observável na produção da narrativa do aluno, na qual ele cria e repete as formas que ele aprendeu ou que vê no seu cotidiano.

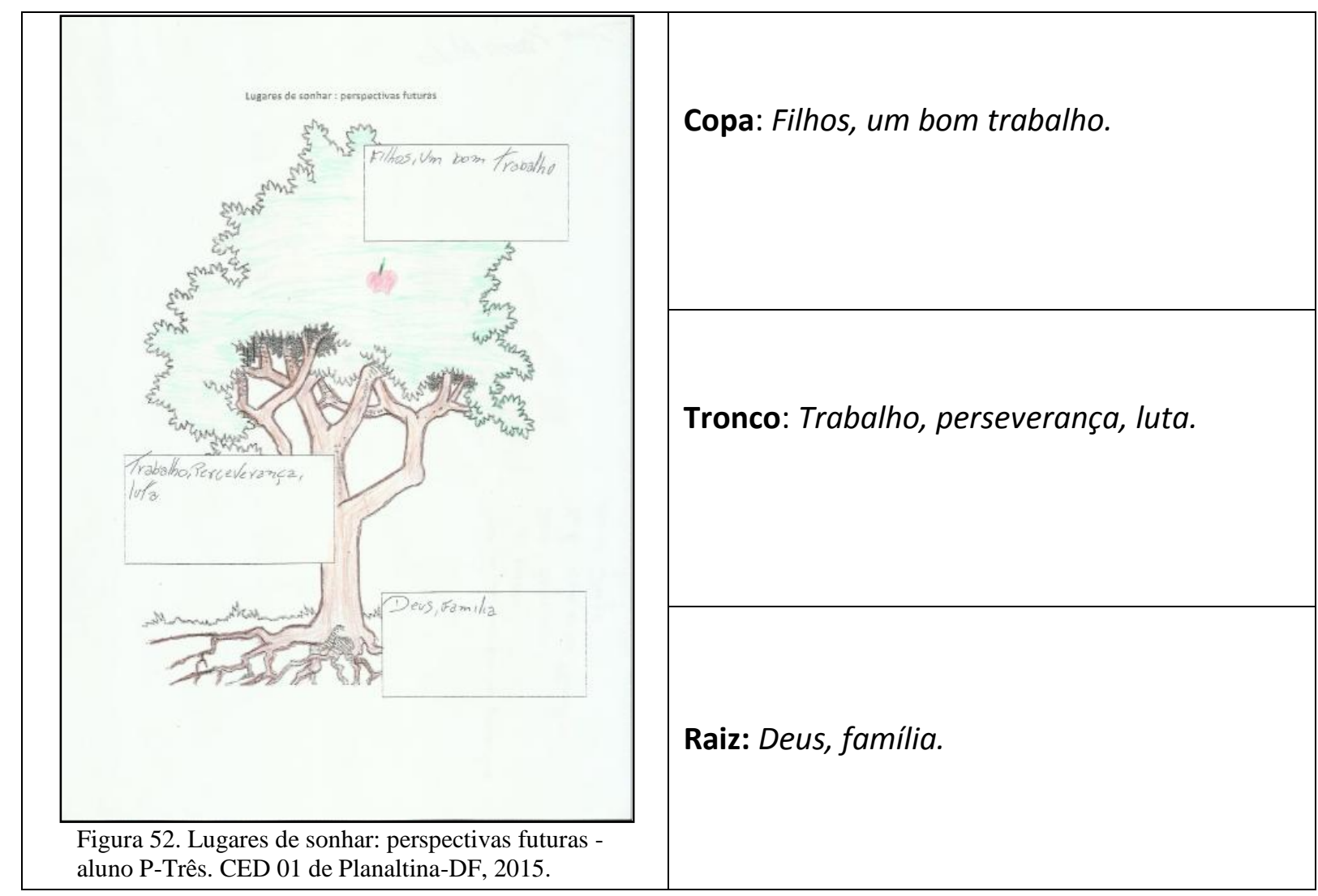

Em sua árvore da vida, figura 52, o seu projeto está relacionado a ter filhos e um bom trabalho. No tronco, permanece o tema trabalho acrescido da palavra perseverança e luta. Como base de seus sonhos temos Deus e a família. 
Na mensagem enviada pelo WhatsApp, figura 53, o aluno reproduz a ideia presente na imagem da cidade, um casal de crianças que se beijam, apresentando a infância com um sentido da vida adulta.

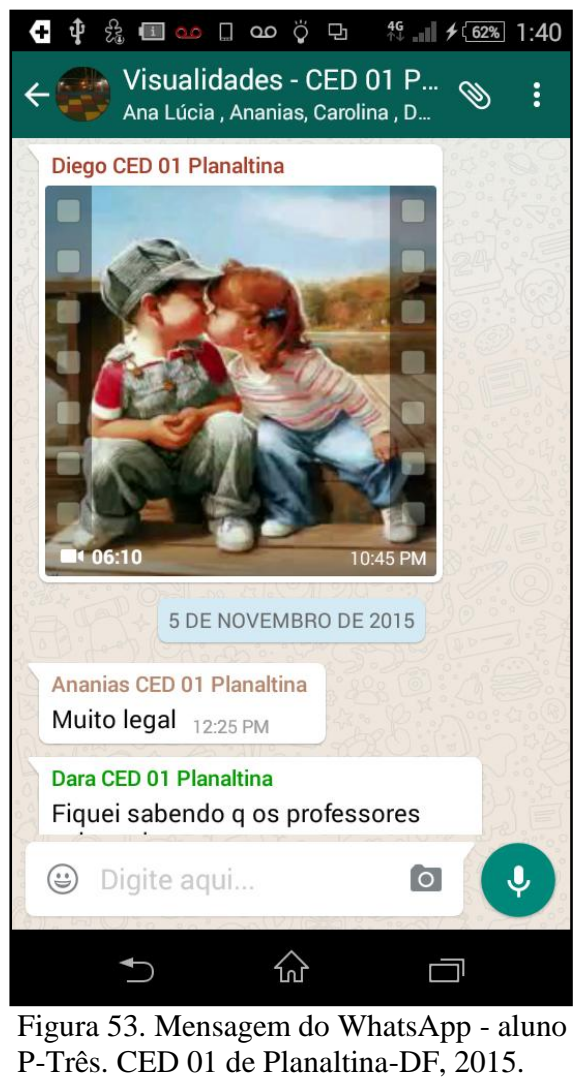

\subsubsection{Narrativa Visual - Aluno P-Quatro}

Na narrativa as lembranças da infância do aluno, figura 54 é apresentada na forma de colagem. A técnica da colagem dá a noção de montagem como articulação entre elementos descontínuos. Ela foi desenvolvida principalmente por Braque e Picasso no final da primeira fase do cubismo. A colagem é considerada um dos achados mais relevantes da arte moderna e um elemento central do cubismo, ao romper com a estética da contemplação, com o primado da interação simbiótica entre o ótico e o mental, afirmado desde o início do modernismo como essencial na pintura.

Nessa narrativa visual o aluno utiliza um elemento não estritamente pictórico - o papel-jornal. Sobreposta em uma folha branca, as imagens de uma estação de metrô com seu trem e passageiros, uma propaganda de um edifício de apartamentos da construtora JC 
Gontijo $^{39}$, uma imagem de uma criança do sexo masculino, um prédio de apartamento cercado de verde e na parte inferior direita uma mochila preta.

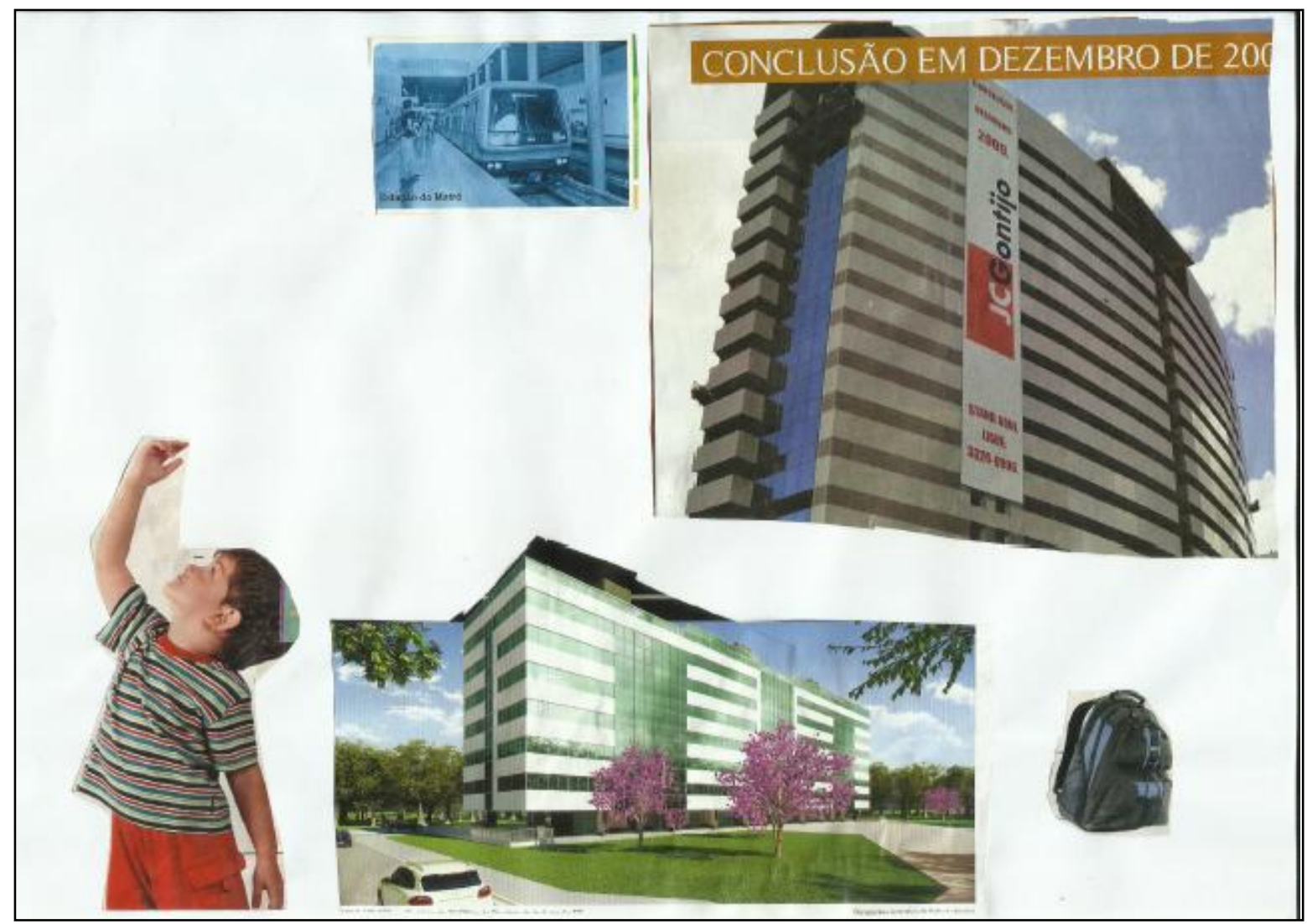

Figura 54. Lugares de lembrar a infância - aluno P-Quatro. CED 01 de Planaltina-DF, 2015.

A narrativa do aluno sugere um cenário mais recente da história do Distrito Federal como a implantação do metrô e a construção de cidades verticais, como por exemplo, Águas Claras. Cabe lembrar que Planaltina ainda não possui metrô e em seu território ainda predominam áreas rurais, diferentemente das imagens presentes na narrativa do aluno. Tais elementos são indícios de que a experiência infantil do aluno ocorreu em outro ambiente espacial.

No texto narrativo sobre a cidade, figura 55, o aluno fala da criminalidade e da ausência de espaços de lazer.

\footnotetext{
${ }^{39}$ Empresa de engenharia de Brasília.
} 


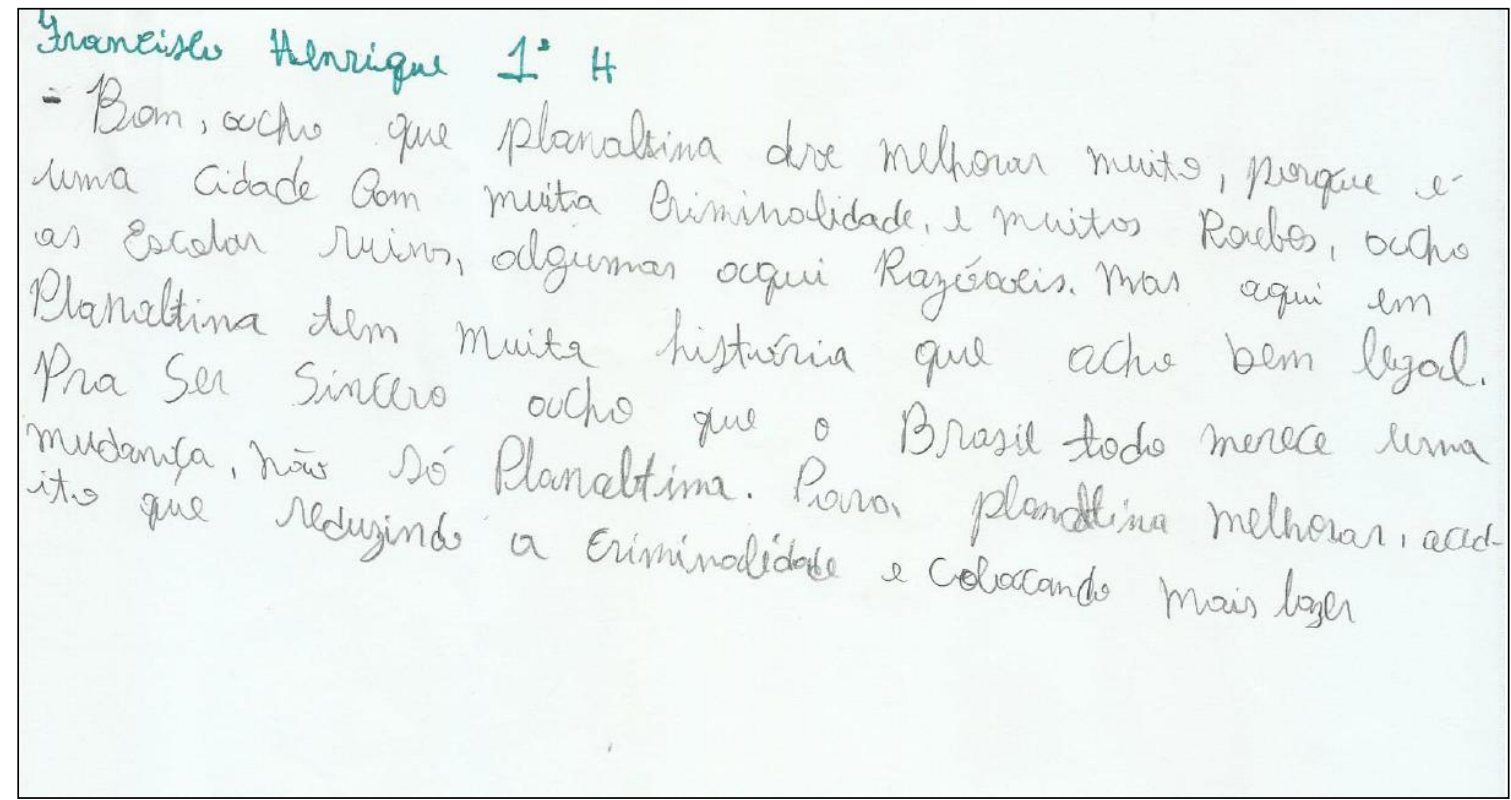

Figura 55. Lugares de lembrar a cidade e sua inserção - aluno P-Quatro. CED 01 de Planaltina-DF, 2015.

A sua narrativa nos leva a reconhecer que o problema da criminalidade não é privilegio da cidade de Planaltina. No Brasil o agravamento da violência urbana se tornou mais evidente a partir de 1980, e acompanhou a crise social, política e econômica, sendo acelerada pela nova ordem econômica da década de 1990, com o aumento das desigualdades sociais e dos contrastes econômicos e sociais nas cidades. Para Abramovay (2002), resultando em novas formas de produção e mudanças sociais, que constituíram o aumento da exclusão de grande parte da população: falta de acesso dos jovens à educação de qualidade, à cultura e ao mercado de trabalho, são aspectos que denotam claramente as desigualdades existentes, que colaboram para o agravamento e aceleramento da violência urbana envolvendo adolescentes.

Dentre as razões apontadas por Abramovay (2002), o aumento do índice de criminalidade urbana é um cenário de exclusão social, no qual se faz presente a violência estrutural que obstrui os meios de amadurecimento e capacitação, para que os adolescentes adquiram formas de conseguir uma inserção social baseada em um trabalho capaz de satisfazer as necessidades mínimas. Demonstra assim, que a violência não se restringe aos atos praticados, mas principalmente, à omissão da sociedade e Estado.

O texto também remete aos espaços de lazer dos centros urbanos e nos leva a perceber que a sua narrativa está em consonância com as ações voltadas às políticas públicas que não priorizam o lazer nas cidades, visto que os espaços não são pensados para se tornarem locais de permanência e convívio social; quando existem, são apropriados pelos poderes públicos para a ampliação de locais de passagem e/ou circulação, como ruas de acesso e alargamento de avenidas. 
Na narrativa sobre as perspectivas futuras, figura 56, o aluno tem a intenção de viajar pelo mundo para conhecer pessoas e culturas diferentes. Para realizar o seu sonho pretende terminar o ensino médio e cursar a faculdade de Psicologia. Reconhece que a sua base familiar é desorganizada.

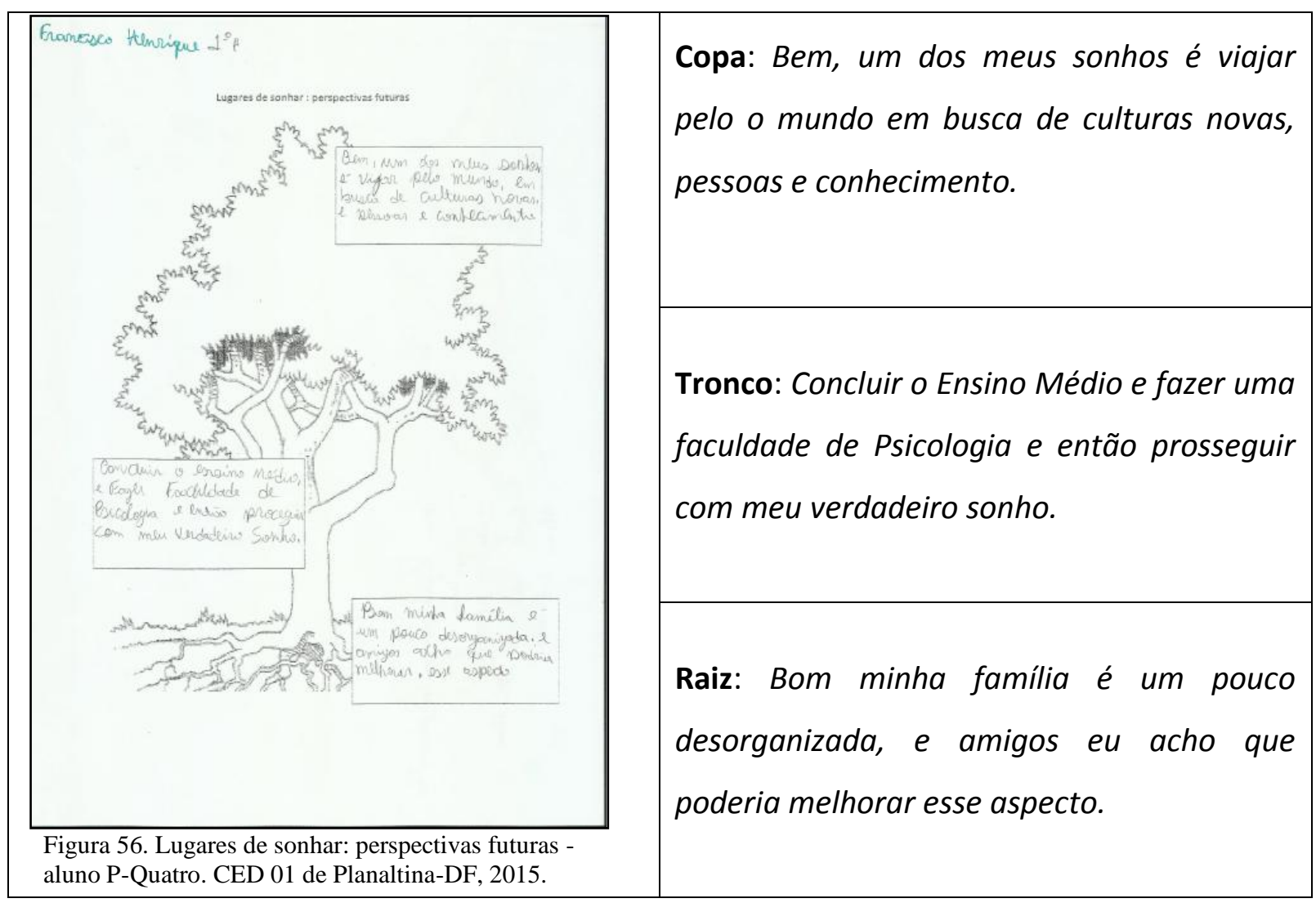

Estudo desenvolvido por Cunha (2005), aponta a apropriação dos discursos verbais e as imagens veiculadas pelos meios de comunicação e sua influência na constituição de nossa identidade. Para a autora, a posse de determinados objetos significa o pertencimento a uma categoria social. O TER significa SER. Compartilhar os mesmos significados significa SER. Tornamo-nos alguém ao nos apropriar de determinados códigos culturais e ao SERMOS alguém, somos detentores de códigos específicos que DIZEM sobre o que e como somos. Para a autora, são estes artefatos que nos representam e nos tornam visíveis ao mundo.

A ânsia de conquista, vislumbrada na narrativa do aluno, é indicativo do desejo de pertencer a uma realidade diferente da sua.

Em sua participação no envio de mensagens por meio do WhatsApp, figuras 57, 58 e 59 o aluno reafirma a ausência de espaços de lazer na cidade e a inexistência de cinema e 
poucos parques, além disso, reconhece que "como cidade de periferia, Planaltina tem muitos usuários de drogas". Outras mensagens fazem referências à greve dos professores.

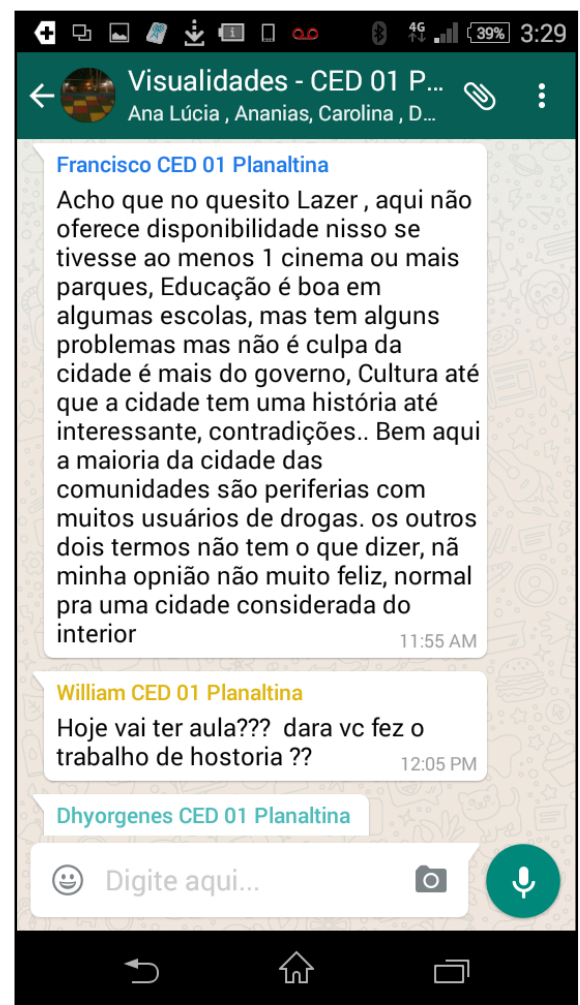

Figura 57. Mensagem do WhatsApp - aluno P-Quatro. CED 01 de Planaltina-DF, 2015.

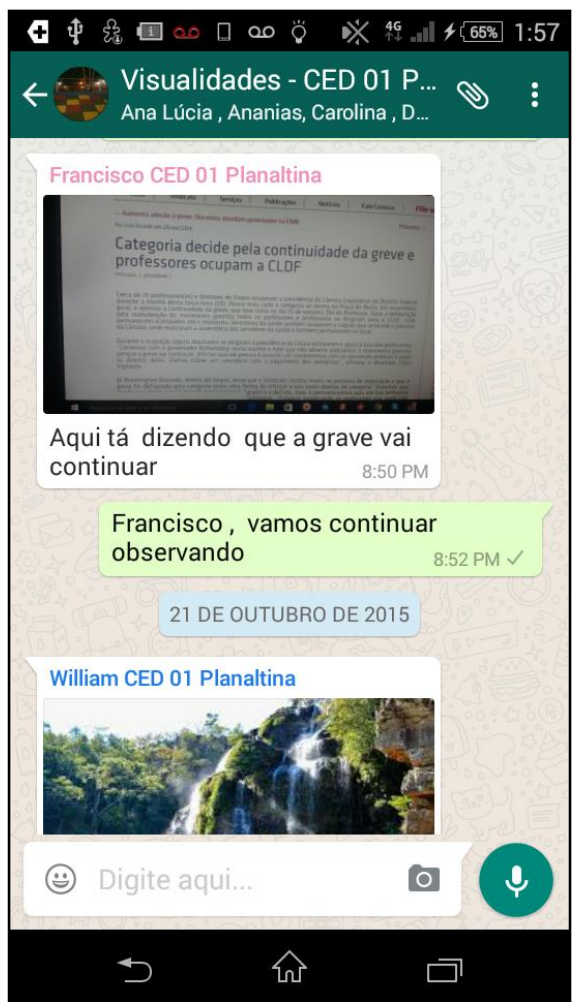

Figura 58. Mensagem do WhatsApp - aluno P-Quatro. CED 01 de Planaltina-DF, 2015.

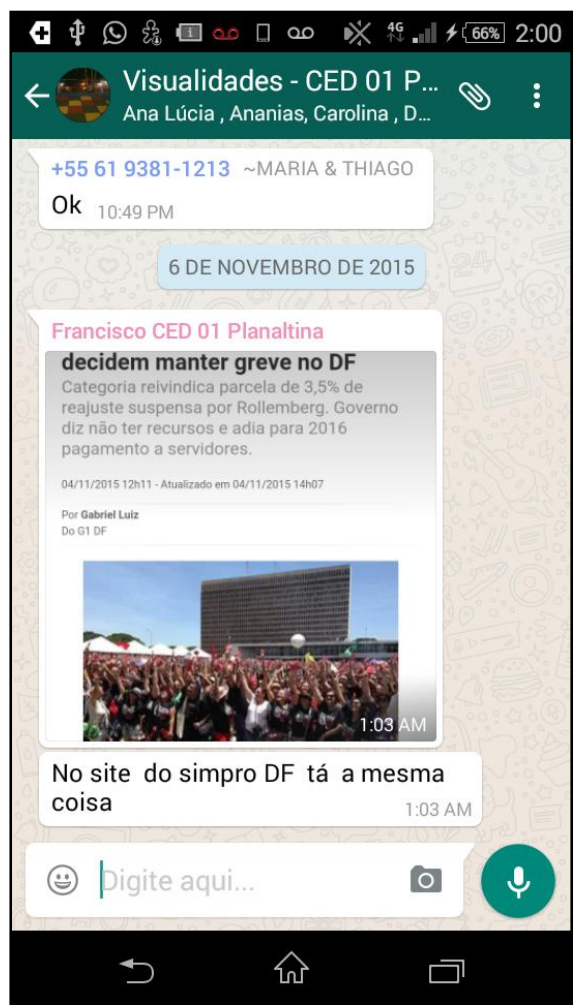

Figura 59. Mensagem do WhatsApp - aluno P-Quatro. CED 01 de Planaltina-DF, 2015. 


\subsubsection{Narrativa Visual - Aluno P-Cinco}

A narrativa visual apresenta um sol amarelo e um céu azulado em um fundo branco. No chão uma imagem de uma criança, pelo tipo de roupa, parece ser do sexo masculino: short vermelho e camiseta azul. Uma tênue linha traça o que parece ser uma manilha, ilustrando assim na figura 60, a brincadeira de correr e gritar em manilhas de obras. Este tipo de brincadeira, típico dos primórdios da construção de Brasília, com seu intenso ritmo de obras, tendo as crianças que se apropriarem daquilo que o ambiente lhes oferecia para criar os seus próprios espaços de brincadeiras.

O aluno se apropria de elementos existentes a fim de torná-los comuns ao seu cotidiano, ocorrendo o deslocamento do consumo supostamente passivo dos produtos recebidos para a criação anônima nascida da prática, do desvio no uso desses produtos, como especifica Certeau (2002), no seu conceito de cotidiano como conjunto de operações singulares que, às vezes, dizem mais de uma sociedade e de um indivíduo do que a sua própria identidade.

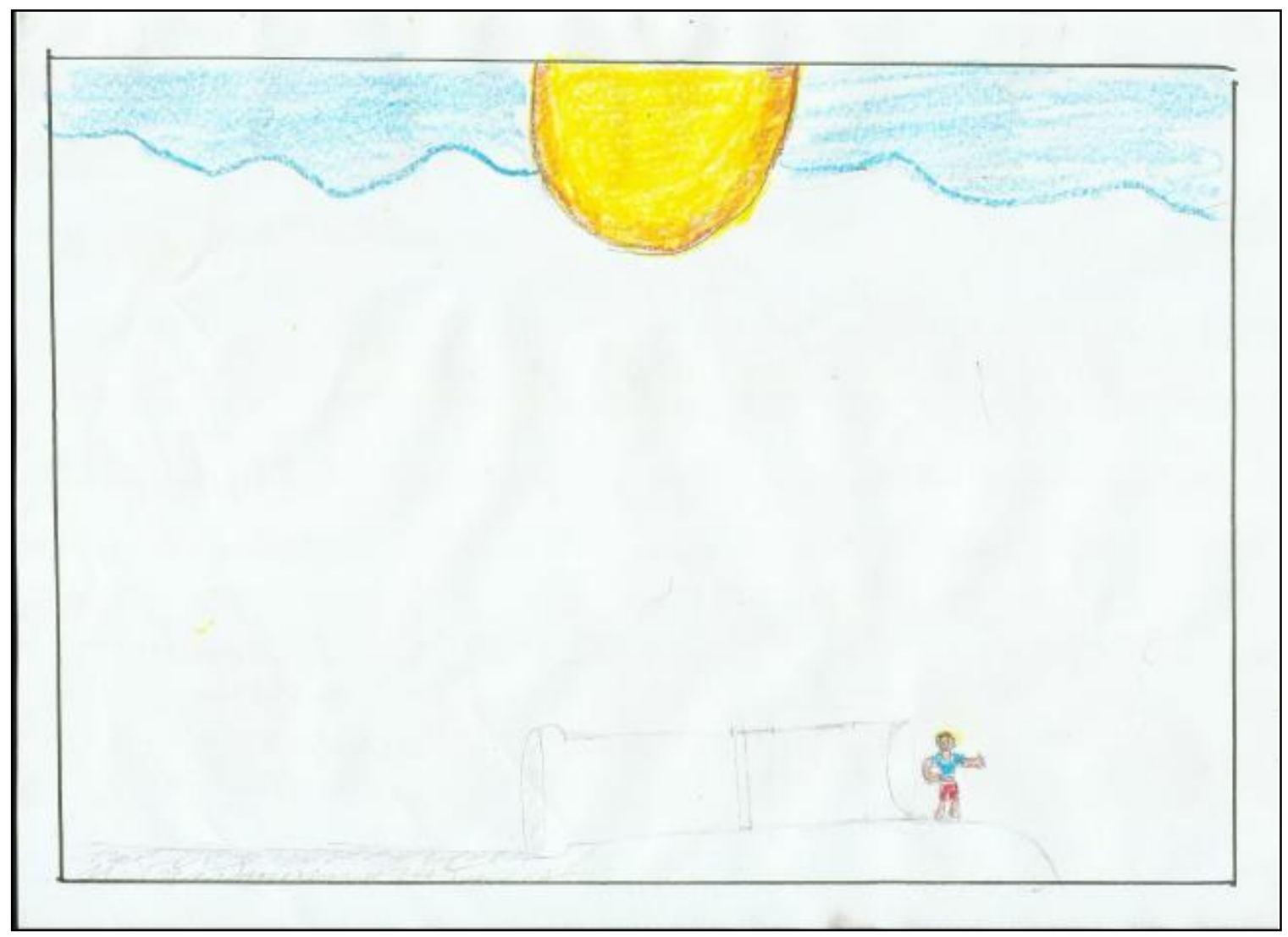

Figura 60. Lugares de lembrar a infância - aluno P-Cinco. CED 01 de Planaltina-DF, 2015. 
A brincadeira presente na narrativa evidencia a tese de Vigotsky (1984) sobre a brincadeira como uma atividade humana criadora, na qual imaginação, fantasia e realidade interagem na produção de novas possibilidades de interpretação, de expressão e de ação pelas crianças, assim como de novas formas de construir relações sociais com outros sujeitos, crianças e adultos. Para o autor, ao brincar a criança reproduz e representa o mundo por meio de situações vivenciadas. Entretanto, essa reprodução não é passiva, ela é mediada por um processo ativo de reinterpretação do mundo, que abre lugar para a invenção e a produção de novos significados, saberes e práticas.

A narrativa visual do aluno sobre a cidade, figura 61, é uma colagem com imagens de ipês amarelos e papel jornal. Os ipês costumam florir em Brasília no período da seca. É grande a quantidade de ipês que colore Brasília entre os meses de junho a outubro, quando desabrocham cerca de 150 mil ipês plantados nos eixos rodoviários, nas superquadras do Plano Piloto e nas regiões administrativas do DF. O ipê é uma planta nativa do cerrado e se desenvolve em locais com temperaturas entre $18^{\circ} \mathrm{C}$ e $26^{\circ} \mathrm{C}$, leva cerca de 20 anos para desenvolver os seus troncos tortuosos com casca grossa e chegam entre 8 a 20 metros de altura. Suas copas coloridas duram poucas semanas e possuem cores que variam entre rosa, roxo, amarelo e branco.

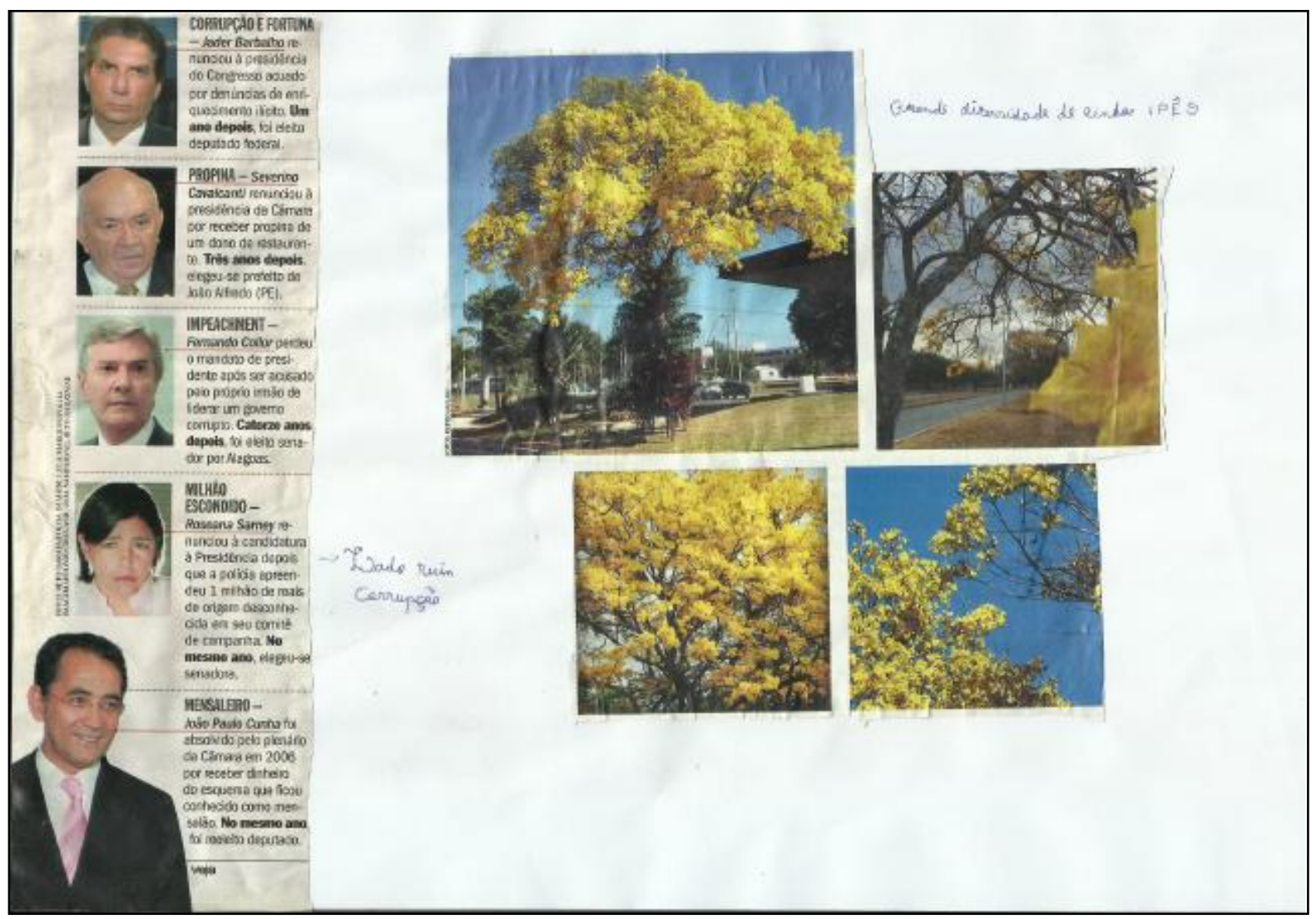

Figura 61. Lugares de lembrar a cidade e sua inserção - aluno P-Cinco. CED 01 de Planaltina -DF, 2015. 
Em oposição à beleza dos ipês, o aluno apresenta a cidade de Brasília como centro do poder e corrupção, apontando as falhas ou ineficiências da administração pública, do sistema político ou da legislação brasileiras, bem como as constantes denúncias de corrupção e impunidade de crimes cometidos por políticos, veiculadas maciçamente pelos meios de comunicação e informação.

A narrativa do aluno traz temas políticos atuais de corrupção. Hoje, percebe-se que os candidatos a cargos políticos fazem suas campanhas eleitorais utilizando as técnicas computacionais para veicular nos meios de comunicação e informação, pautadas em efeitos imagéticos que por muitas vezes transformam os anseios da sociedade - educação, saúde, moradia, trabalho, em meros efeitos especiais, a fim de torná-los atraentes e ganharem votos.

Assim como as deslumbrantes campanhas publicitárias destinadas ao mercado de consumo influenciam, as pessoas em geral, as campanhas eleitorais se utilizam de imagens nos meios de comunicação e informação para também, influenciar e atrair seus eleitores.

Num tempo não muito distante, os discursos políticos faziam uso somente da palavra escritas e falada sem a utilização de recursos imagéticos.

Atualmente, com os recursos das tecnologias, as campanhas eleitorais se tornaram aparentes com uso de imagens e pelo que elas produzem em efeitos, o que as tornam mais fortes e facilmente assimiladas, mesmo não pertencendo a uma realidade possível.

Ao falar de seus sonhos e perspectivas futuras, figura 62, o aluno narra: 


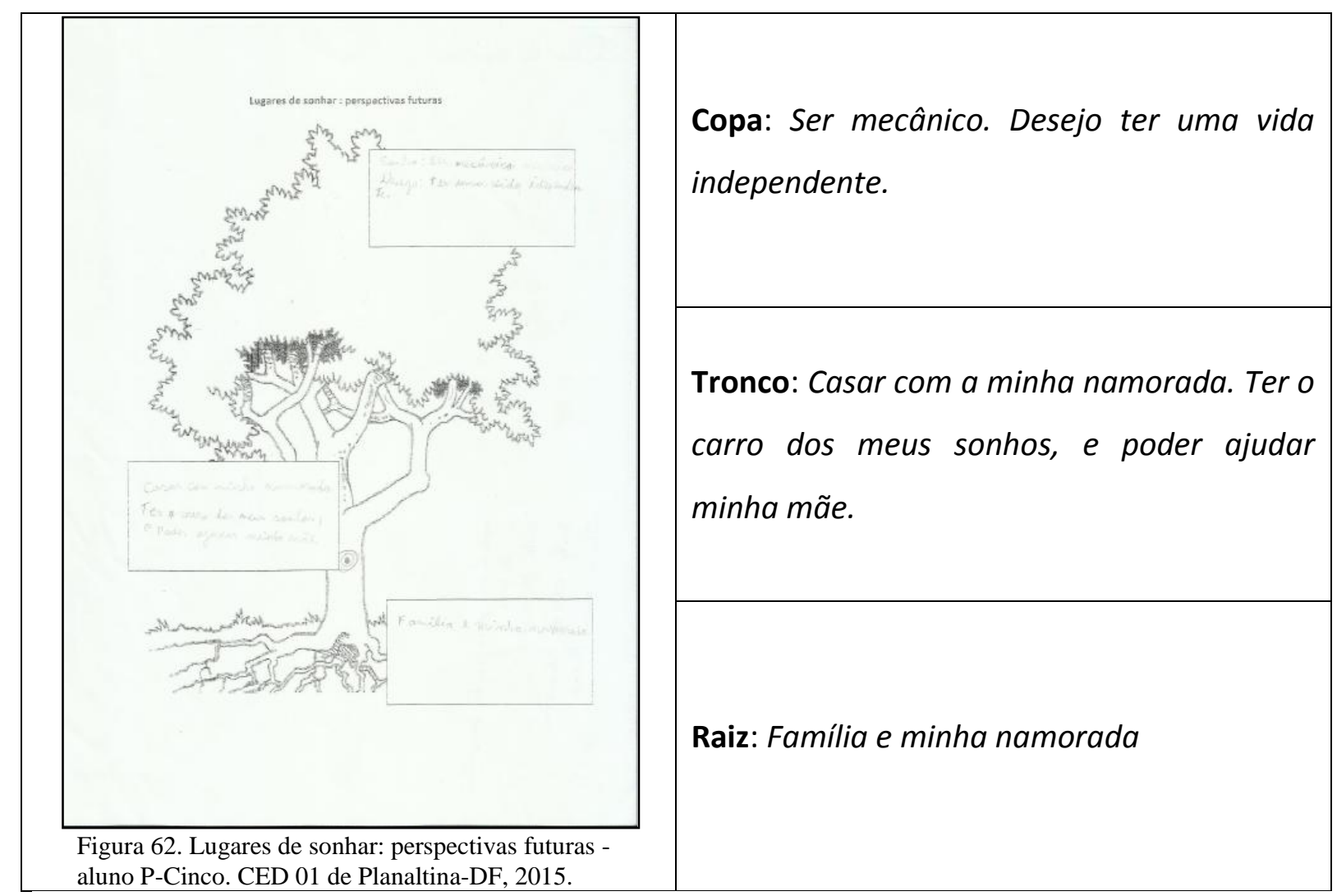

O aluno deseja ser mecânico e ter uma vida independente. Pretende casar com a namorada, ter o carro dos sonhos e ajudar, possivelmente financeiramente, a sua mãe. A base de seus sonhos se sustenta na família e na namorada.

As narrativas das lembranças da infância e da cidade do aluno não se fixaram na cidade de Planaltina e se centraram na capital, diferentemente das imagens da cidade enviadas por mensagens.

As imagens enviadas via WhatsApp pelo aluno, são todas de pontos turísticos da cidade de Planaltina, apresentada como espaço de permanência de realização de atividades de convívio e recreação, em oposição ao espaço da cidade de Brasília de circulação e passagem dos pedestres.

Na figura 63, o aluno retrata o Museu Histórico e Artístico de Planaltina ${ }^{40}$; a praça, situada no centro de Planaltina, a figura 64, a Igrejinha de São Sebastião ${ }^{41}$ e a encenação da Via Sacra. Já na figura 65, aparecem duas imagens, a primeira da Igreja Matriz de São Sebastião e o portão da cidade de Planaltina. E por fim, figura 66 a seguir, mensagens do aluno sobre suas lembranças de infância.

\footnotetext{
${ }^{40} \mathrm{O}$ museu situado no Setor Tradicional da cidade, foi construído no final do século XIX, em arquitetura portuguesa e estilo colonial.

${ }^{41}$ Capela construída em 1870.
} 


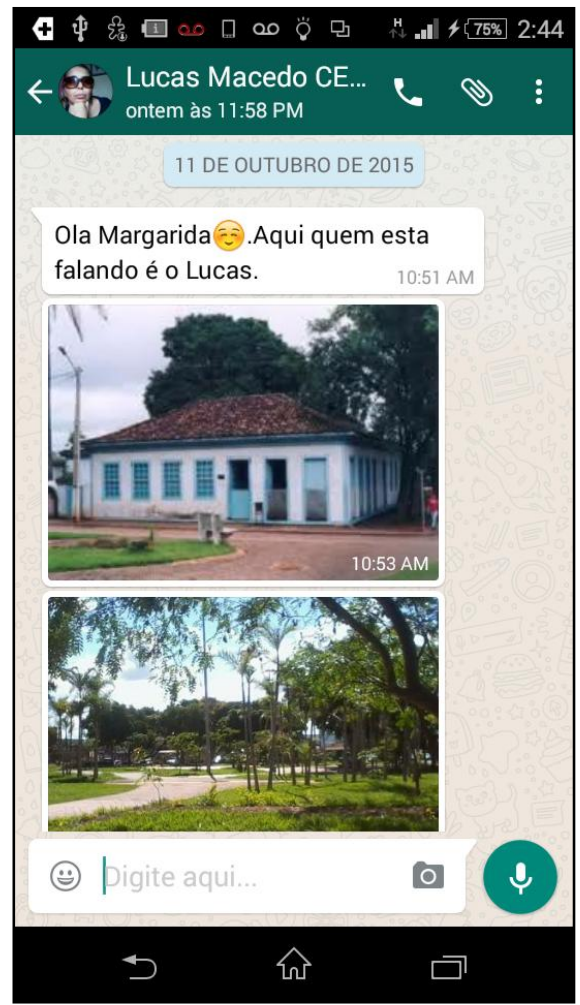

Figura 63. Mensagem do WhatsApp - aluno P-Cinco. CED 01 de Planaltina-DF, 2015.

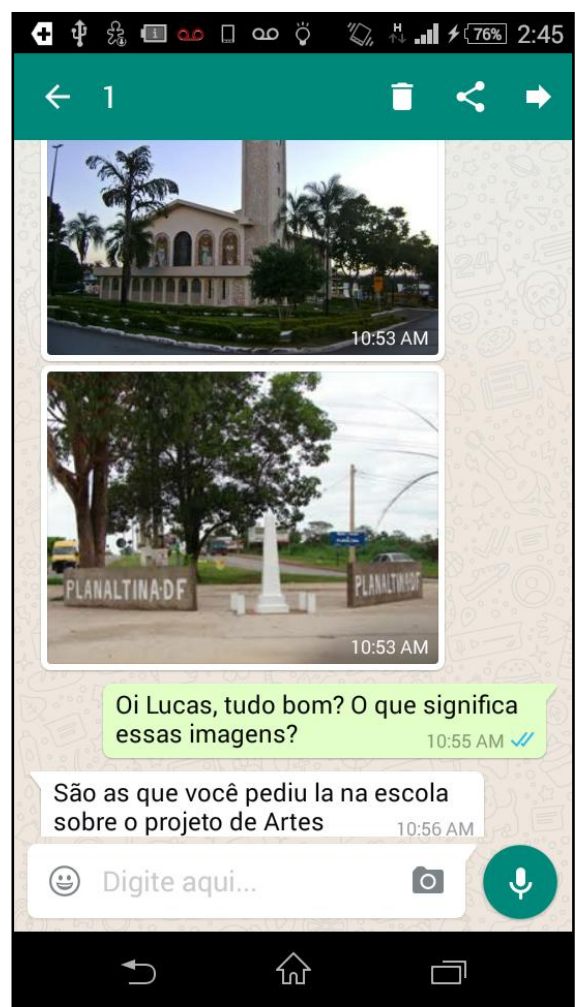

Figura 65. Mensagem do WhatsApp - aluno P-Cinco. CED 01 de Planaltina-DF, 2015.

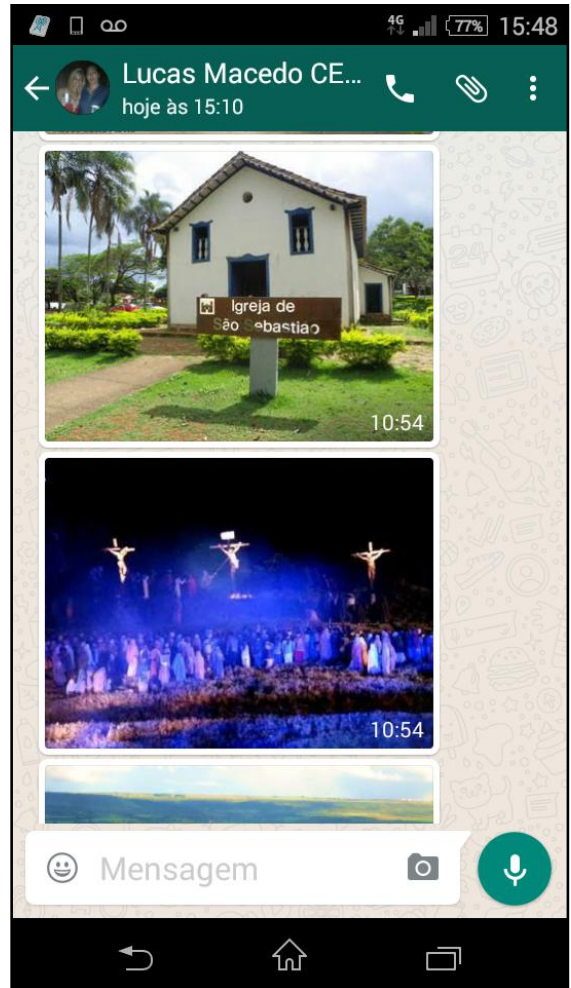

Figura 64. Mensagem do WhatsApp - aluno P-Cinco. CED 01 de Planaltina-DF, 2015.

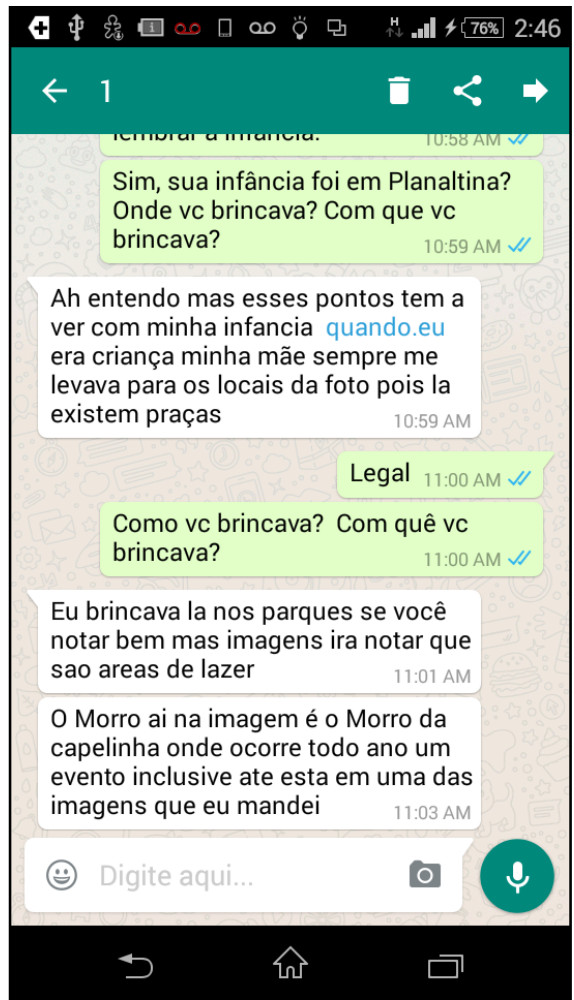

Figura 66. Mensagem do WhatsApp - aluno P-Cinco. CED 01 de Planaltina-DF, 2015. 


\subsubsection{Narrativa Visual - Aluna P-Um}

A narrativa visual da aluna, figura 67, é uma colagem realizada em uma folha de papel A4, formada por cinco imagens: três telefones portáteis; uma criança com uma boneca nos braços, observa-se que o rosto da criança que carrega a boneca nos braços não aparece, o destaque é para a boneca; um par de patins; um conjunto de maquiagem e a apresentação da Amazônia pela Turma da Mônica.

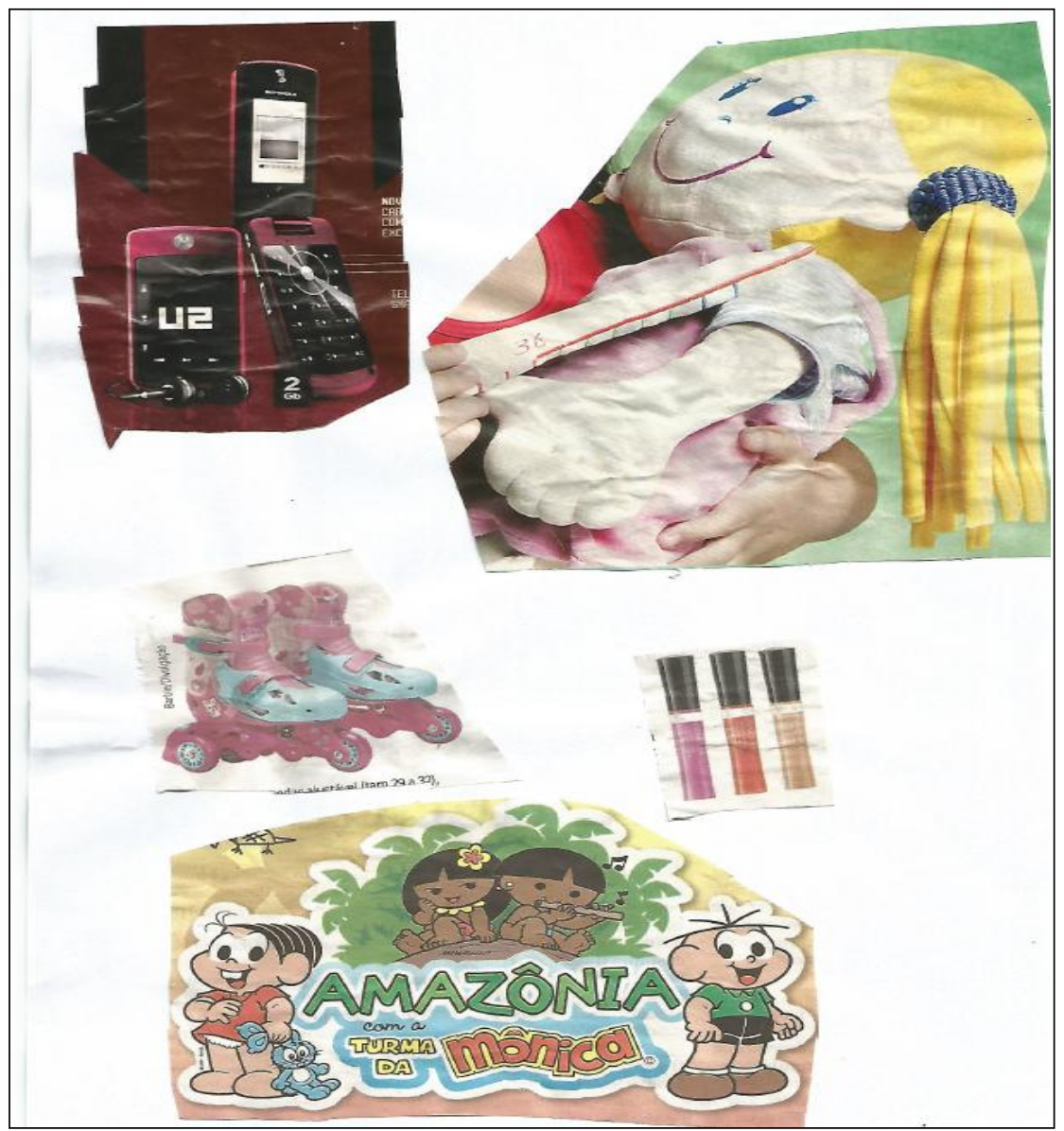

Figura 67. Lugares de lembrar a infância - aluna P-Um. CED 01 de Planaltina-DF, 2015.

$\mathrm{Na}$ narrativa da aluna, representa o desejo pela boneca de pano, isso induz a pensar que ocorre uma espécie de fetichismo da mercadoria ${ }^{42}$, onde os produtos parecem ganhar vontade própria, deixando de ser objetos e passam a ser alvo de adoração pelo ser humano,

\footnotetext{
${ }^{42} \mathrm{O}$ fetichismo da mercadoria é uma expressão cunhada por Karl Marx (1818-1883) na obra-prima intitulada O Capital (1867), significando o caráter que as mercadorias possuem, dentro do sistema capitalista, de ocultar as relações sociais de exploração do trabalho, sedimentando-se, por conseguinte, em toda a sociedade. Ver Fábio César da Silva. O conceito de fetichismo da mercadoria cultural de T.W. Adorno e M. Horkheimer: uma ampliação do fetichismo marxiano. Revista Kínesis, Vol. II, n 03, Abril-2010, p. 375-384. Disponível em http://www.marilia.unesp.br/Home/RevistasEletronicas/Kinesis /FabioCesardaSilva.pdf.
} 
havendo uma inversão: os indivíduos se comportam como objetos e os objetos passam a ter vida.

Neste contexto, o ideal da criança feliz está estritamente relacionado a uma sociedade de consumo que associa brincadeiras e consumo, à medida que os pais presenteiam seus filhos com artefatos tecnológicos que distanciam as crianças das brincadeiras ao ar livre.

Sugere também a configuração contemporânea da sociedade de consumo como forma de massificação/homogeneização social. A sua principal características é o desejo socialmente expandido da aquisição do "supérfluo", do excedente, do luxo. Essa sociedade se estrutura pela marca da insaciabilidade, da constante insatisfação, onde uma necessidade preliminarmente satisfeita gera outra necessidade, num ciclo que não se esgota.

Para Bauman (2008), esse tipo de sociedade se configura a partir das mudanças estruturais desenvolvidas no século XVIII na Europa Ocidental, especialmente com a Revolução Industrial, acelerada a partir da segunda metade do século XX, quando o universo do consumo passou a ganhar centralidade tanto como motor do desenvolvimento econômico quanto com a expansão do consumismo como elemento de mediação de novas relações e processos que se estabeleceram nos planos sociais e culturais.

Dessa forma, a sociedade de consumo tem suas origens no período de consolidação da modernidade na Europa Ocidental dos séculos XVIII e XIX, sendo esse processo radicalizado no contexto das sociedades contemporâneas, servindo como referência para construções intelectuais. Bauman (2008), ao avaliar os efeitos da troca da sociedade de produtores por uma sociedade de consumidores, observa que nessa nova organização social, os indivíduos se tornam ao mesmo tempo promotores de mercadorias e também as próprias mercadorias que promovem.

Sabemos que a escolha de palavras e imagens para construir o discurso, mesmo parecendo uma atitude ingênua, nunca está livre de carga ideológica de quem faz o texto. Isto é bem perceptível com a imagem trazida pela aluna da Turma da Mônica na Amazônia.

Atualmente, existem mais de 200 etnias conhecidas e espalhadas pelo Brasil, embora tentem nos convencer que os índios estão fixados nos recônditos da Amazônia, possuindo uma concepção de mundo fora da realidade do restante da sociedade.

$\mathrm{Na}$ imagem da aluna predomina o senso comum sobre o indígena, mostrando-o como selvagem catequizado, amansado, ingênuo, ignorante e em harmonia com a natureza, como exóticos em sua língua, seus trajes e seus costumes, em oposição aos ocidentais e civilizados. 
O que a imagem desvela é uma visão distorcida e preconceituosa que obscurece a compreensão da cultura indígena, e que é aceita pela sociedade brasileira sem qualquer senso crítico. O que deixa visível, como afirmado por Ticiana Horn (2010, p. 191), em seu artigo: $E$ qui eu num sei nada di nada! Visualidades sobre a infância rural em artefatos visuais endereçados às crianças (2010, p. 206), a "necessidade de pensarmos no quanto o nosso olhar está pré-moldado, incluiu e excluiu, e o quanto precisamos propor um trabalho crítico das imagens com as crianças para que se desnaturalize o que já está naturalizado".

A sua narrativa sobre a cidade, figura 68 a seguir, é constituída pela técnica de colagem com dois recortes de jornal, ambos falando de morte/destruição. A primeira mostra o atropelamento de uma criança a caminho da escola. Possivelmente, uma alusão aos constantes acidentes de carros na rodovia DF 130, que passa por dentro da cidade, ligando o Distrito Federal ao Estado de Goiás. Com isso, o fluxo de carros é intenso, ocasionando eventualmente, graves acidentes automobilísticos.

Segundo estudo realizado pelo Instituto Avante Brasil (2010), em termos absolutos, o Brasil é o $4^{\circ}$ país do mundo com maior número de mortes no trânsito, ficando atrás somente da China, Índia e Nigéria.

Jorge e Latorre (1994) observam que no Brasil as mortes no trânsito representam um sério problema de saúde pública, pois ocorrem em grande número e atingem na sua maioria a população jovem, constituindo a principal causa de morte no grupo etário de 5 a 39 anos de idade. 


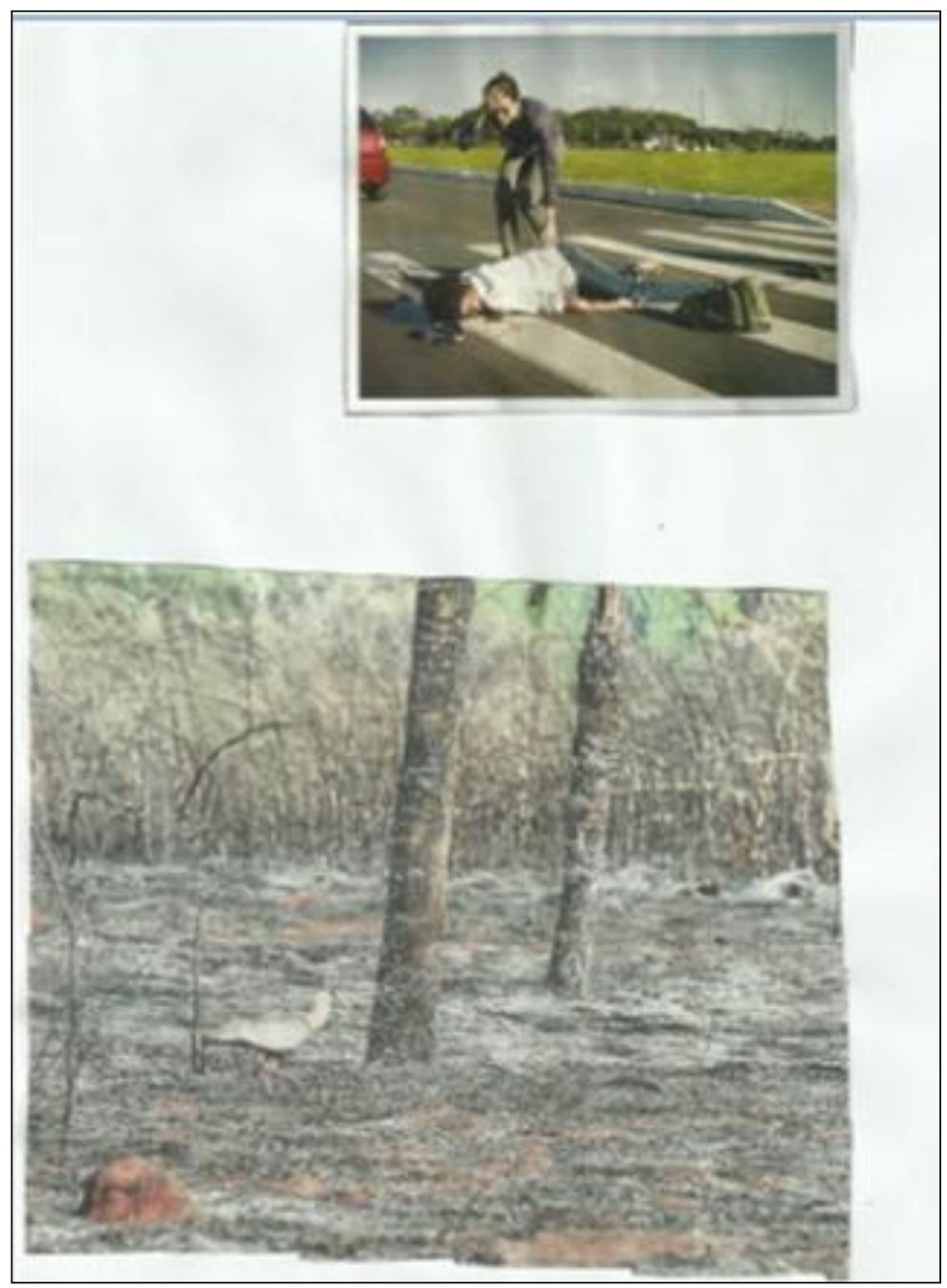

Figura 68. Lugares de lembrar a cidade e sua inserção - aluna P-Um. CED 01 de Planaltina-DF, 2015.

A segunda imagem está relacionada às constantes queimadas sofridas pela savana ${ }^{43}$ brasileira que abriga 5\% das espécies animais e vegetais do mundo. Para o Ministério do Meio Ambiente - MMA, o cerrado é o segundo maior bioma da América do Sul, ocupando uma área de $2.036 .448 \mathrm{~km}^{2}, 22 \%$ do território nacional. A sua área contínua incide sobre os Estados de Goiás, Tocantins, Mato Grosso, Mato Grosso do Sul, Minas Gerais, Bahia, Maranhão, Piauí, Rondônia, Paraná, São Paulo e Distrito Federal, além dos encraves no Amapá, Roraima e Amazonas.

A palavra cerrado, de origem espanhola, significa "fechado", traduzindo a característica do bioma: vegetação densa de arbustos e gramíneas, com árvores baixas e

\footnotetext{
43 As savanas são vegetações típicas de locais com estação seca bastante longa, queimadas constantes, e em regiões de clima tropical com transição para outros tipos de biomas (no Brasil, faz transição com todos os outros biomas exceto os pampas). Caracterizada basicamente por uma vegetação de gramíneas (herbácea) e arbustos, a savana possui uma vegetação bastante resistente ao fogo. As gramíneas apresentam folhas compridas que aproveitam ao máximo as chuvas e rizomas resistentes à seca. www.infoescola.com/geografia/savanas.
} 
tortuosas. O cerrado apresenta extrema abundância de espécies, no qual inúmeras plantas e animais correm riscos de extinção. As principais razões que contribuem para a extinção são: ocupação humana, uso indiscriminado do solo para a produção de carne e grãos para exportação, progressivo esgotamento dos recursos naturais da região, queimadas no período de seca e exploração predatória de material lenhoso para a produção de carvão.

Sobre as suas perspectivas futuras, figura 69 , a aluna deseja terminar os estudos, não especificando se em nível de educação básica ou ensino superior. Em termos profissionais, deseja ser uma policial civil e uma grande cantora, cujo sonho está intimamente ligado à remuneração do policial civil aliado à vocação e prazer de cantar, ou ao glamour que essas profissões proporcionam em seu imaginário, por um lado, a autoridade maior capaz de repreender pessoas e, por outro lado de ter a atenção de todas as pessoas em ser uma cantora de sucesso. Seu olhar, possivelmente é influenciado pelas imagens das mídias. Pereira e Martins (2007) no artigo Cultura visual e identidade(s) no desenho pedagógico informa que:

\footnotetext{
Isoladamente, as imagens são apenas fragmentos ou películas de realidade. Mas, quando organizadas, elas ganham intensidade e sentido gerando narrativas que operam como focos de mediação da cultura. Revestidas desse poder e portadoras de uma materialidade volátil, as imagens atuam como memória e como presença/ausência, influenciando olhares, subjetividades e, sobretudo, identidades. Por esta razão, a cultura visual se preocupa com as práticas e experiências integradas à visualidade, analisando as imagens sempre em contexto, em relação aos discursos que mediam representações e narrativas visuais. (PEREIRA e MARTINS, 2007, p. 612)
}

Os autores reafirmam o que se procurou desenvolver no decorrer da pesquisa, na qual as imagens atuam como presença/ausência que influenciam a subjetividade e o modo como nós vemos o mundo, como nos relacionamos com o mundo e com as outras pessoas.

Em seus sonhos, a aluna evidencia o desejo do carro e da casa própria em um lugar melhor para viver com a sua família. A aluna acredita que existe uma associação entre educação e ascensão social, já que relaciona a efetivação de seus desejos com o término dos estudos. A base para os seus sonhos se assentam na família e na religião. 


\begin{tabular}{|l|l|l|}
\hline & $\begin{array}{l}\text { Copa: Sonho é terminar os estudos, se } \\
\text { formar em policial civil, ser uma grande } \\
\text { cantora e morar em outro lugar melhor com } \\
\text { a minha familia ter minha casa e meu carro. }\end{array}$ \\
& $\begin{array}{l}\text { Tronco: Um que já concretizei foi meu curso } \\
\text { de Inglês e o que ainda quero terminar os } \\
\text { estudos e dar um futuro melhor pra minha } \\
\text { familia. }\end{array}$ \\
\hline $\begin{array}{l}\text { Figura 69. Lugares de sonhar: perspectivas futuras - } \\
\text { aluna P-Um. CED 01 de Planaltina-DF, 2015. }\end{array}$ & $\begin{array}{l}\text { Raiz: Minha base com certeza está em Deus, } \\
\text { minha familia e a lgreja. }\end{array}$ \\
\hline
\end{tabular}

Pelo WhatsApp a aluna enviou oito mensagens, figuras 70, 71, 72, 73, 74, 75, 76 e 77. São fotografias do local onde costumava passar as férias de final de ano, na cidade natal de seus pais (Bahia), parques e praças do Plano Piloto e Planaltina, fotos de sua residência e em uma das mensagens, afirma que "os principais problemas da cidade são: transporte público, atendimento hospitalar e alto índice de criminalidade". 


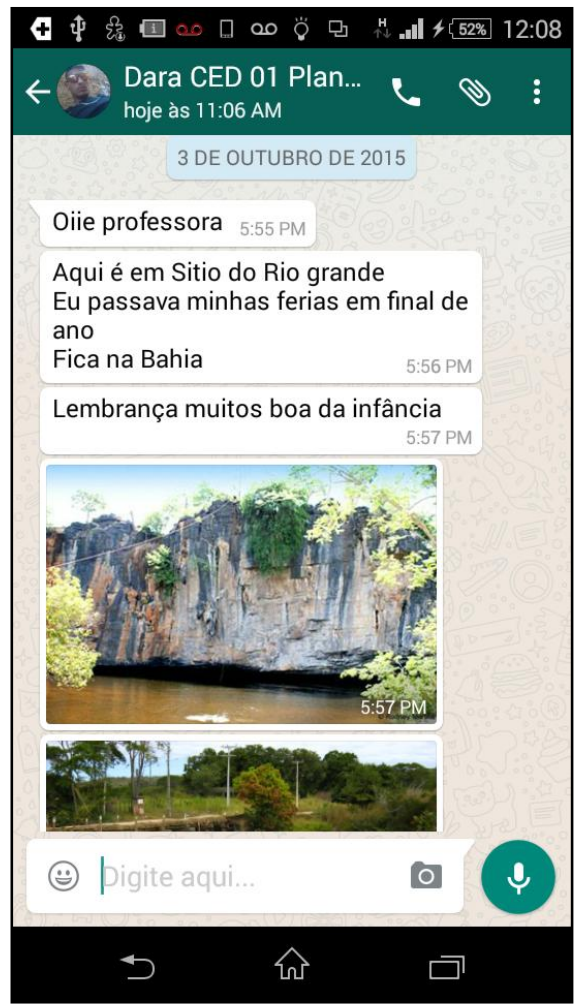

Figura 70. Mensagem do WhatsApp - aluna P-Um. CED 01 de Planaltina-DF, 2015.

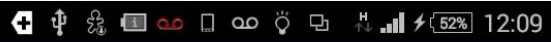

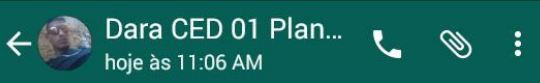

Aqui é lugares q ja fui muitas vezes

mais meus pais

E também com amigos

Eu amava o zoológico
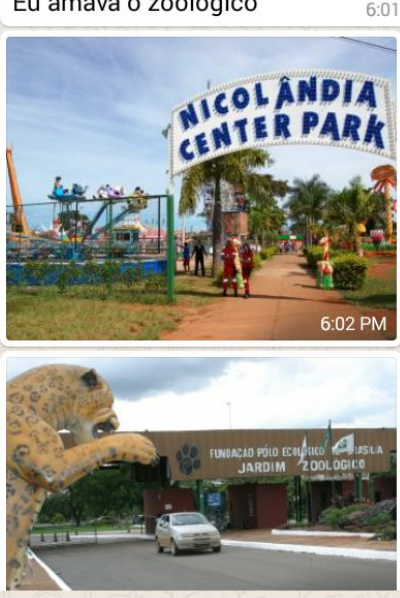

(:) Pigite aqui

은

$\square$

仓ิ

$\square$

Figura 72. Mensagem do WhatsApp - aluna P-Um. CED 01 de Planaltina-DF, 2015.

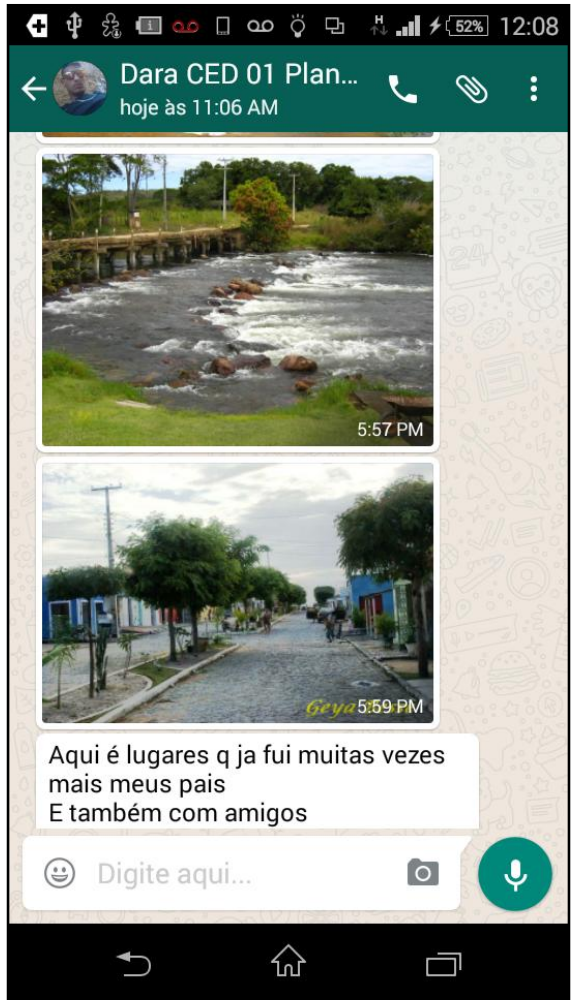

Figura 71. Mensagem do WhatsApp - aluna P-Um. CED 01 de Planaltina-DF, 2015.

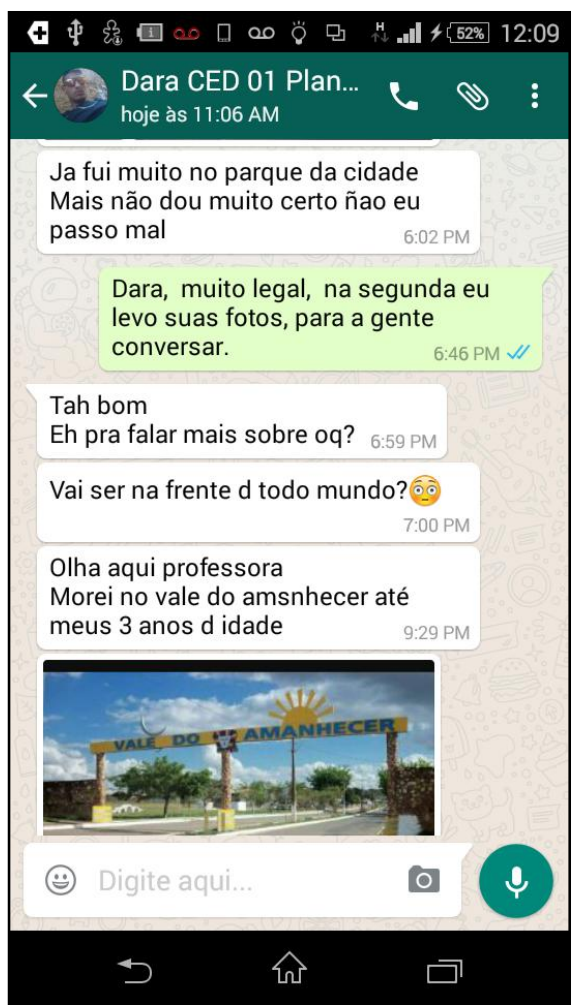

Figura 73. Mensagem do WhatsApp - aluna P-Um. CED 01 de Planaltina-DF, 2015. 




Figura 74. Mensagem do WhatsApp - aluna P-Um. CED 01 de Planaltina-DF, 2015.

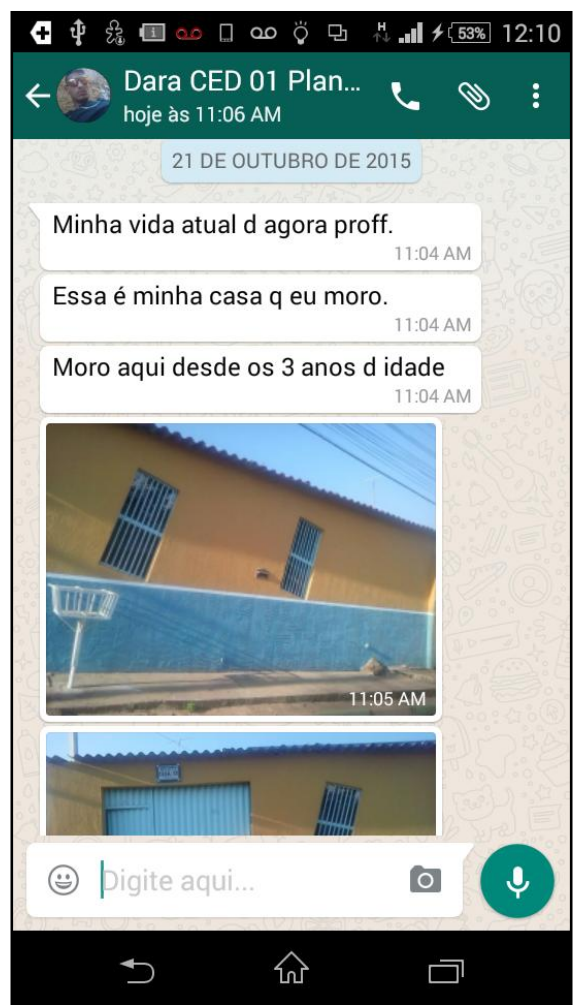

Figura 76. Mensagem do WhatsApp - aluna P-Um. CED 01 de Planaltina-DF, 2015.

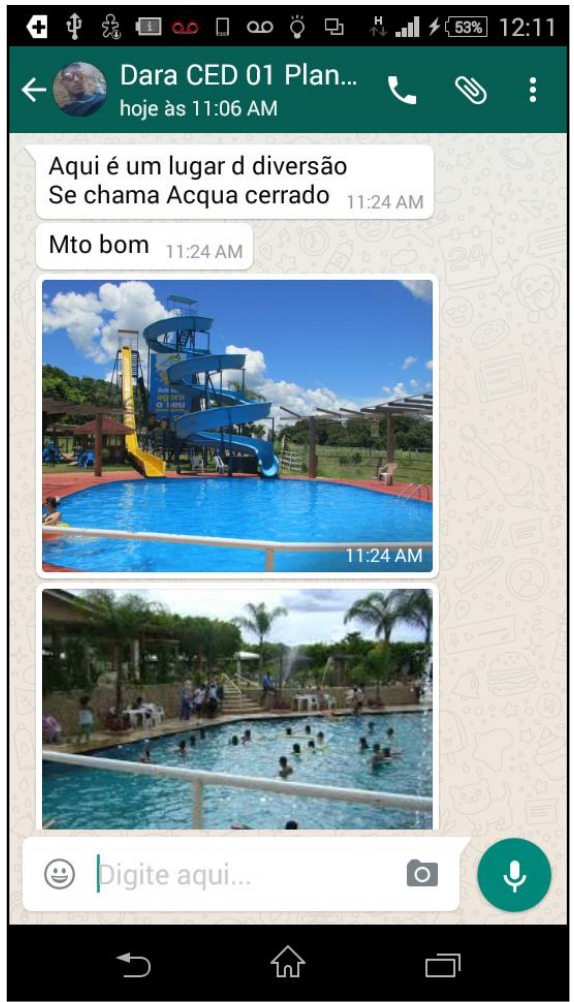

Figura 75. Mensagem do WhatsApp - aluna P-Um. CED 01 de Planaltina-DF, 2015.



Figura 77. Mensagem do WhatsApp - aluna P-Um. CED 01 de Planaltina-DF, 2015. 
As narrativas apresentadas pela aluna remetem a uma infância desenvolvida em espaços naturais e de lazer, de forma saudosista, demonstra uma preocupação atual com a degradação dos serviços públicos, como o transporte coletivo.

\subsubsection{Narrativa Visual - Aluna P-Seis}

A narrativa, figura 78, associa colagem e desenho. Três colagens: no canto superior esquerdo a propaganda de uma boneca; no centro, um fantasma e no canto direito, uma jovem jogando bola. Em seguida, no canto inferior, o desenho de uma casa, com duas pequenas janelas e uma porta, ao lado da casa, um buquê com três flores, presumindo que seja um jardim ao lado da casa.

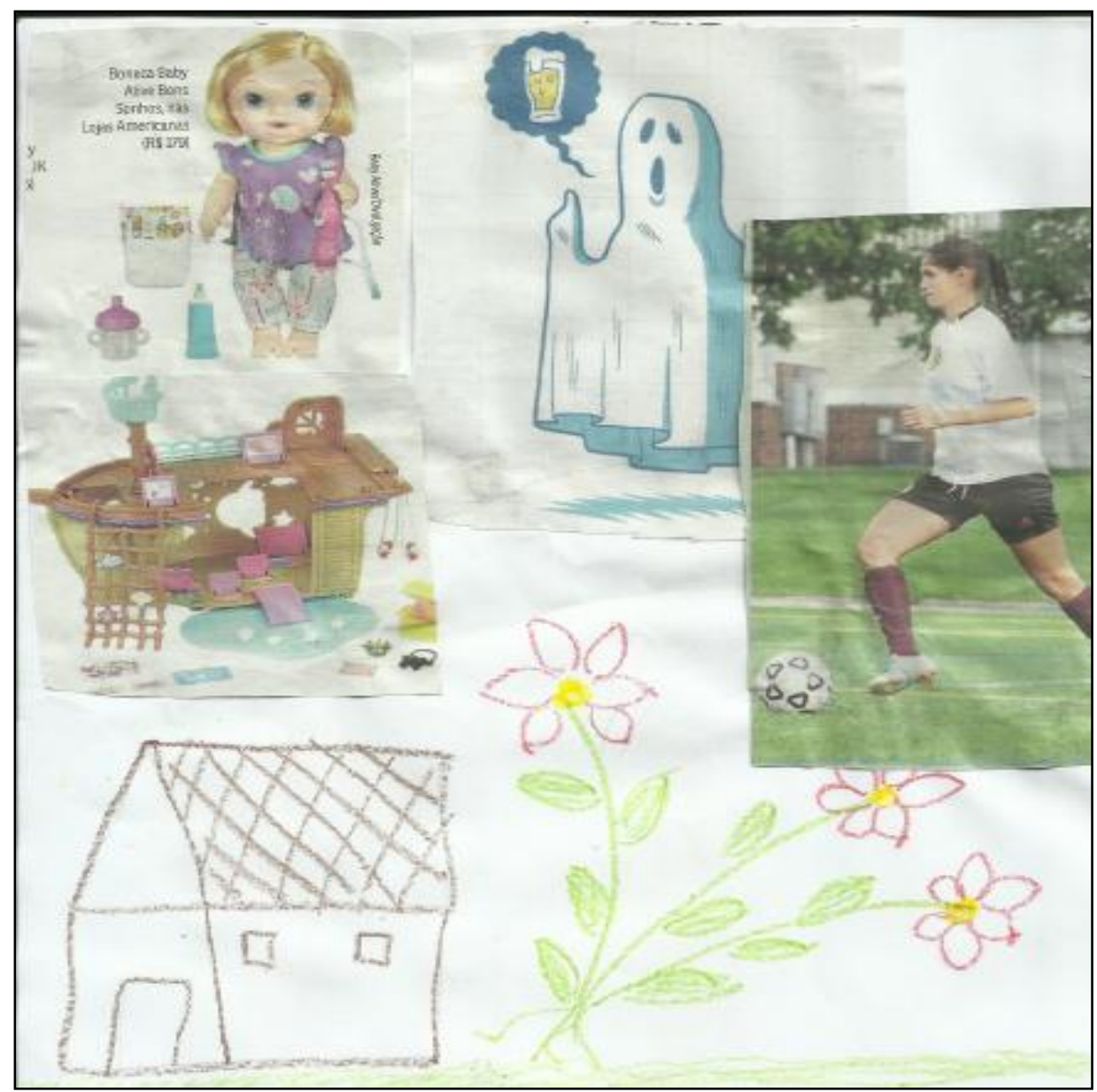

Figura 78. Lugares de lembrar a infância - aluna P-Seis. CED 01 de Planaltina-DF, 2015.

É evidente tratar-se de uma narrativa feminina parecendo reproduzir a casa de uma família nuclear com o seu ideal da imagem feminina como a responsável pela casa e pela 
educação das crianças, sendo esta ideia visualizada pelos elementos que constituem a brincadeira de boneca.

Historicamente, a brincadeira infantil de boneca é representativa do conceito que a sociedade tem da infância, desvelando discursos, concepções e representações de determinada sociedade e cultura. Segundo Ariès (2006), os bonecos e bonecas tiveram sua origem nas imagens e estatuetas com significação religiosa, presentes na vida humana desde os primórdios da humanidade. No início, as crianças não tinham o direito de se aproximar e manipular essas estátuas que eram tidas como objetos sagrados.

Na Idade Média, a proibição vai esvanecer, pois não havia diferença entre adultos e crianças, até por volta dos sete anos de idade, sendo as atividades coletivas, não distinguindo nem sexo nem idade. Nesse contexto, as bonecas eram objetos destinados aos adultos e às crianças, partilhadas por ambos os sexos da mesma forma que o tipo de vestimenta.

Essa situação começou a ser transformada na passagem do feudalismo para o capitalismo. Com a produção fabril, a família e a escola afastaram a criança da sociedade dos adultos, modificando-se, inclusive, a arquitetura das casas, com o advento dos cômodos e o início da vida privada. Segundo Ariès (2006), a emergência do sentimento de infância e da criança como um ser inocente e necessitada de cuidado e proteção, associado com a criação de universo paralelo vivido pela criança vinha permeado de um aparato de tecnologias e produtos voltados especificamente para a infância. Surgem as bonecas destinadas a essa idade. No século XVIII, passam a ser produzidas em grande escala. Para Ariès (2006, p. 203), "é no advento das bonecas industrializadas destinadas às crianças que está a invenção da infância".

No século $\mathrm{XX}$, os fabricantes passaram a produzir bonecas com distintos materiais, tais como borracha, espuma e vinil. Segundo estudo de Cruz (2011), no século XX, as bonecas e bonecos receberam uma conotação de produção a partir da aplicação de diferentes técnicas e conhecimentos, como a análise do mercado, as expectativas do consumidor, a criatividade, o design das embalagens e acessórios, e os testes em modelos fabricados, resultando em três principais correntes contemporâneas: as bonecas bebê, as bonecas manequim e as figuras de ação.

Para Brougère (2004, apud Cruz 2011), a boneca bebê foi criada no processo de industrialização do século XIX, com o intuito de representar a criança de forma mais realista e de simbolizar a maternidade. Por representarem a criança como bebê ou menina, essas 
bonecas permitem e incentivam a representação de uma relação afetiva de cuidado por meio de atos como alimentar, acalentar, pentear, vestir, desenvolvendo rituais de afeição.

Em relação às bonecas manequins, o objetivo já não é cuidar e alimentar a criançaboneca, mas ser a boneca adulta. Segundo Cruz (2011), no início elas eram feitas de porcelana, corpo de tecido e utilizavam roupas com modelagem da moda. A principal representante é a boneca Barbie, criada por Ruth Handler, inspirada nas brincadeiras com bonecas de sua filha Bárbara. A boneca Barbie foi apresentada em 1959, em uma feira de brinquedos em Nova Iorque, fazendo sucesso entre as crianças. A sua inovação estava na possibilidade das meninas poderem possuir apenas uma boneca, já que estas podiam ter diversas roupas. Com a boneca Barbie as adolescentes deixavam de embalar bonecas bebê, voltando-se para a alta costura.

Os bonecos voltados para os meninos ou as figuras de ação, surgiram no século XVII, com os soldadinhos de chumbo. Em seguida, passaram a representar os caubóis norteamericanos. Segundo Cruz (2001), em 1964, a empresa de brinquedos Hasbro, criou os GI Joe, um boneco militar caracterizado com uniformes diferentes. A partir do GI Joe foram criados muitos outros bonecos, como os Comandos em Ação, Power Ranger e mais recentemente, Max Steel.

Miranda (2014) ao analisar os diversos desenhos e alusões visuais referentes à comemoração dos 50 anos da boneca Barbie em 2009, observa, na perspectiva da cultura visual, que tais visualidades "reforçam mensagens, pretensiosamente inocentes por alusivas ao mundo infantil, mas que atribuem valores predominantes as condições de desejo (sexual, físico, material, moral) fundada em experiências estéticas” (Miranda, 2014, p. 301).

Neste universo infantil constituído pelo adulto é possível perceber uma "naturalização" de objetos representativos de uma infância, sempre apresentada como uma fase inocente e feliz.

A narrativa visual da aluna sobre a cidade, constituída de colagem apresenta uma variedade da gastronomia local, figura 79. Evidencia-se forte influência da culinária nordestina, goiana e mineira, demonstrando ser a alimentação um produto da miscigenação cultural, que revela vestígios das trocas culturais. Essa constatação tem despertado o estudo sobre a formação do gosto alimentar, tanto pelo aspecto nutricional, biológico e histórico, como as manifestações culturais e sociais de um determinado contexto histórico. 


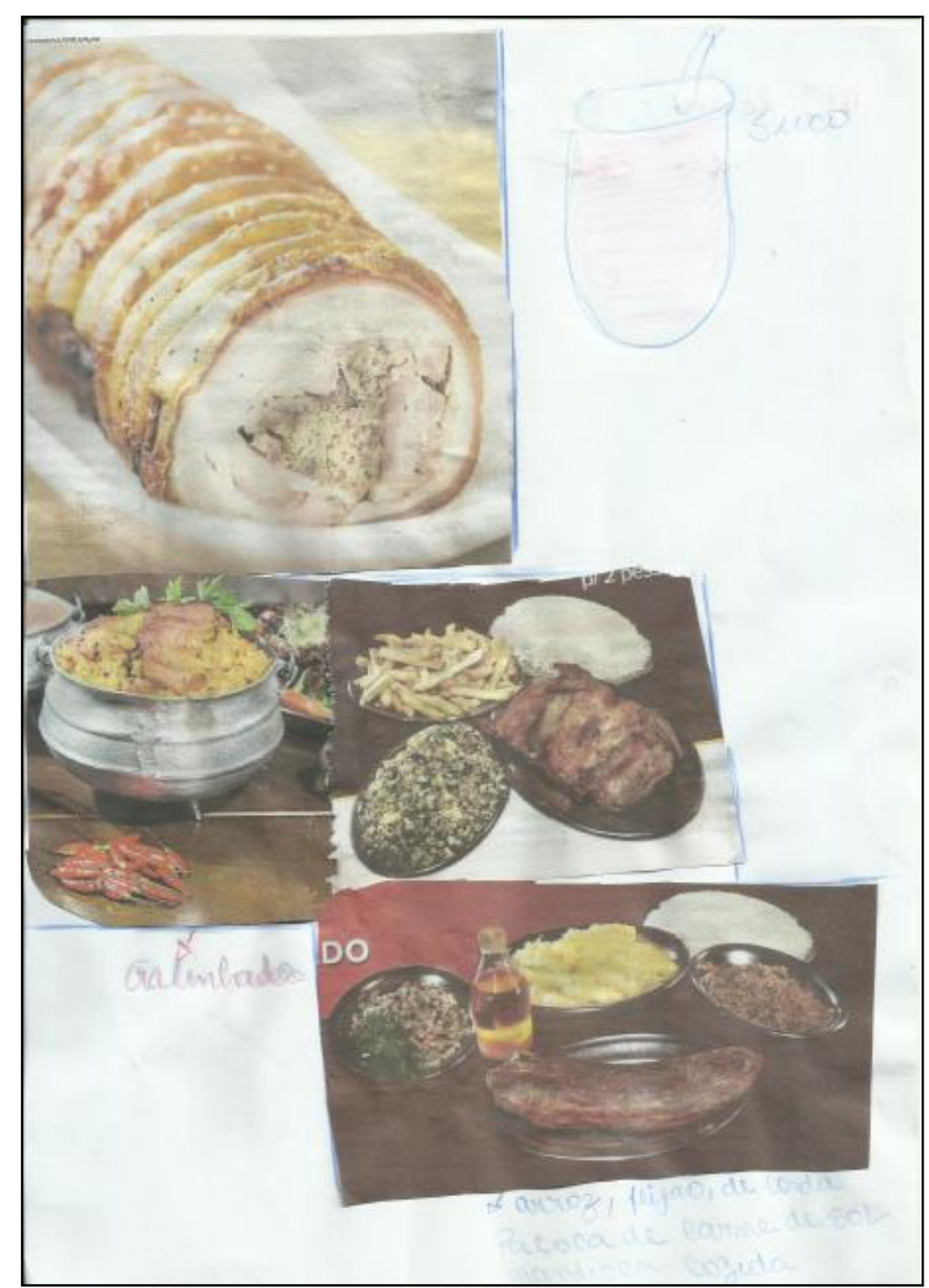

Figura 79. Lugares de lembrar a cidade e sua inserção - aluna P-Seis. CED 01 de Planaltina-DF, 2015.

A alimentação como manifestação cultural constitui o estudo de Visser (1998) ao afirmar que o homem transforma o consumo do alimento, que é uma necessidade biológica, numa necessidade cultural, usando o ato de comer como um veículo para relacionamentos sociais ${ }^{44}$.

Em sua árvore da vida, figura 80 demonstrada na página a seguir, a aluna coloca como perspectivas futuras terminar a educação básica, cursar uma faculdade, conseguir um emprego melhor e ter a sua casa e carro próprios. O tronco de sua árvore é constituído pela família e a raiz pela religião e também pela família, evidenciando forte apreço familiar e religioso.

44 Um passeio virtual pela gastronomia regional brasileira pode ser feito no site: http://www.museugastronomiabrasileira.com.br/museu_itinerante_SET.pdf 


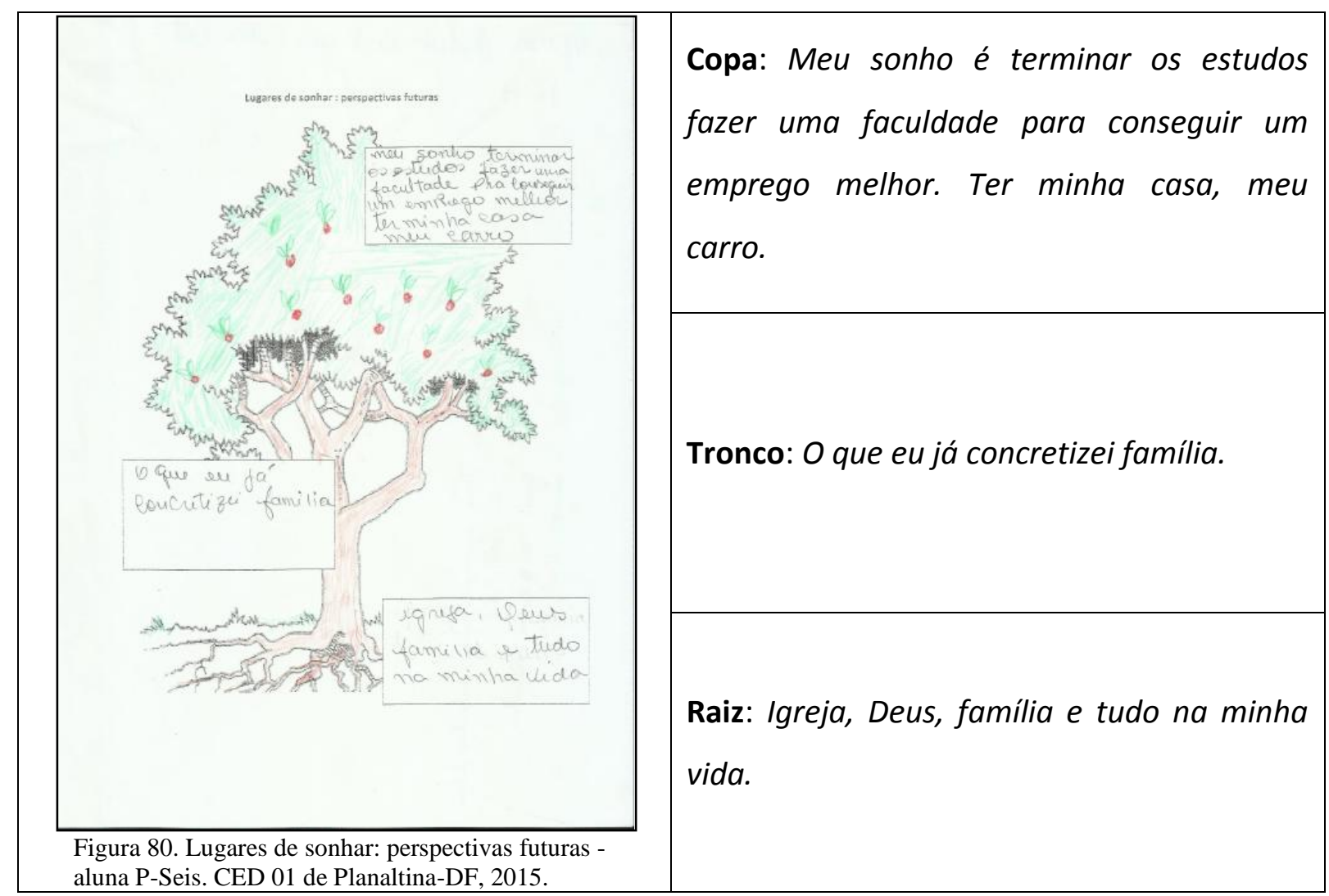

As mensagens enviadas pelo WhatsApp, figuras 81, 82, 83, 84, 85 e 86 são imagens de uma chácara localizada no Estado de Goiás, onde a aluna passa, esporadicamente, os finais de semana. A ênfase da narrativa visual na gastronomia regional e na vida rural evidenciam a origem interiorana da aluna e o lado rural na cidade de Planaltina. 


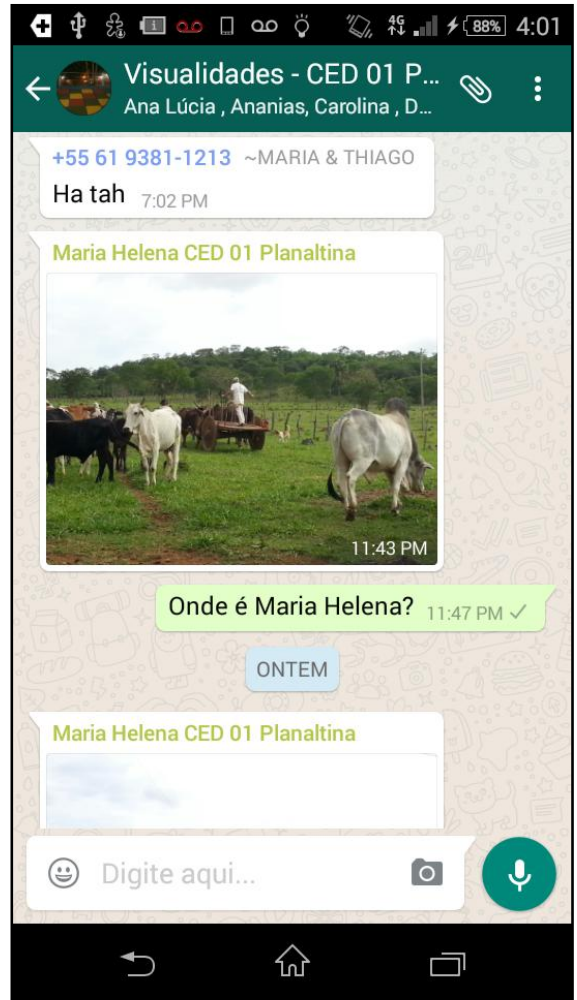

Figura 81. Mensagem do WhatsApp - aluna P-Seis. CED 01 de Planaltina-DF, 2015.

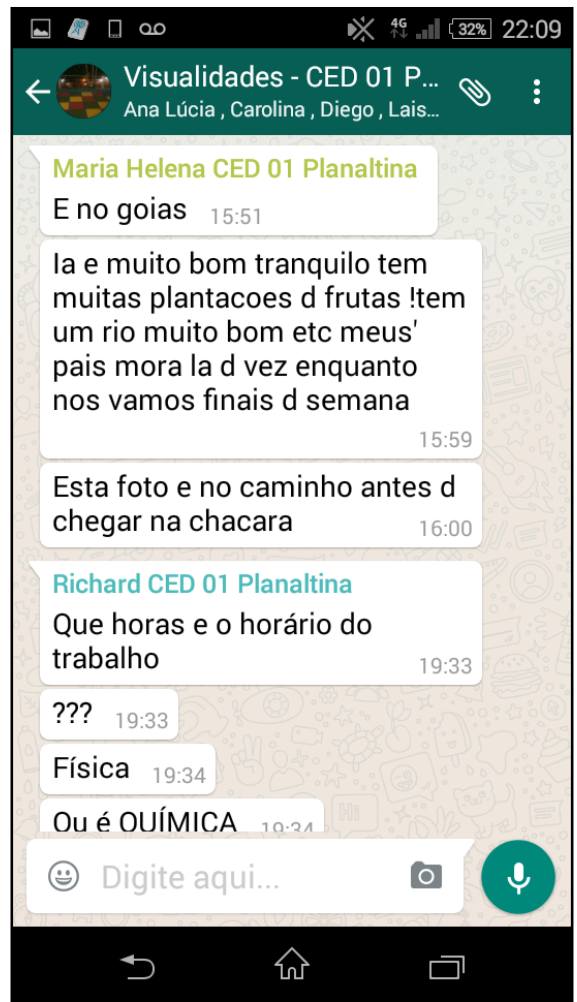

Figura 83. Mensagem do WhatsApp - aluna P-Seis. CED 01 de Planaltina-DF, 2015

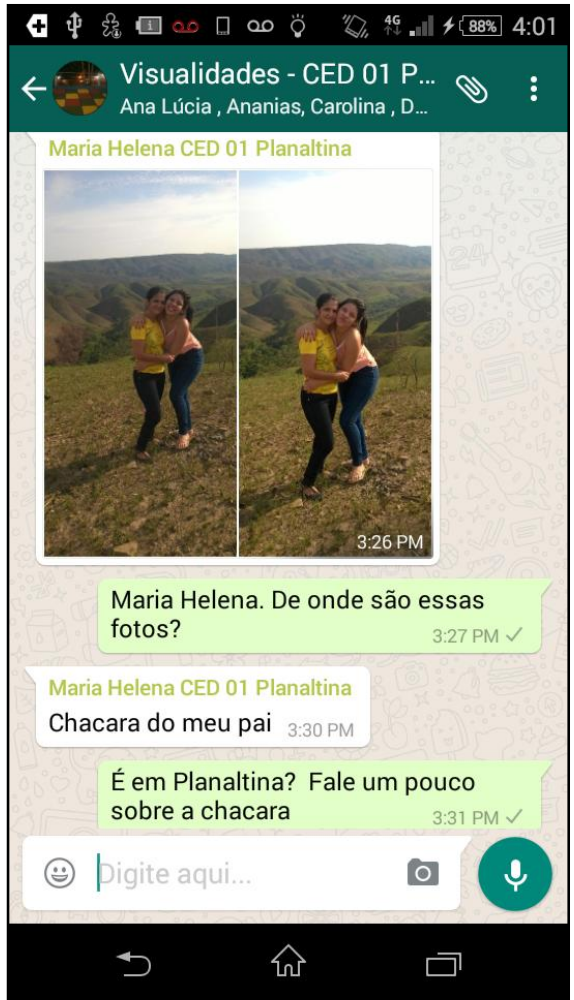

Figura 82. Mensagem do WhatsApp - aluna P-Seis. CED 01 de Planaltina-DF, 2015.

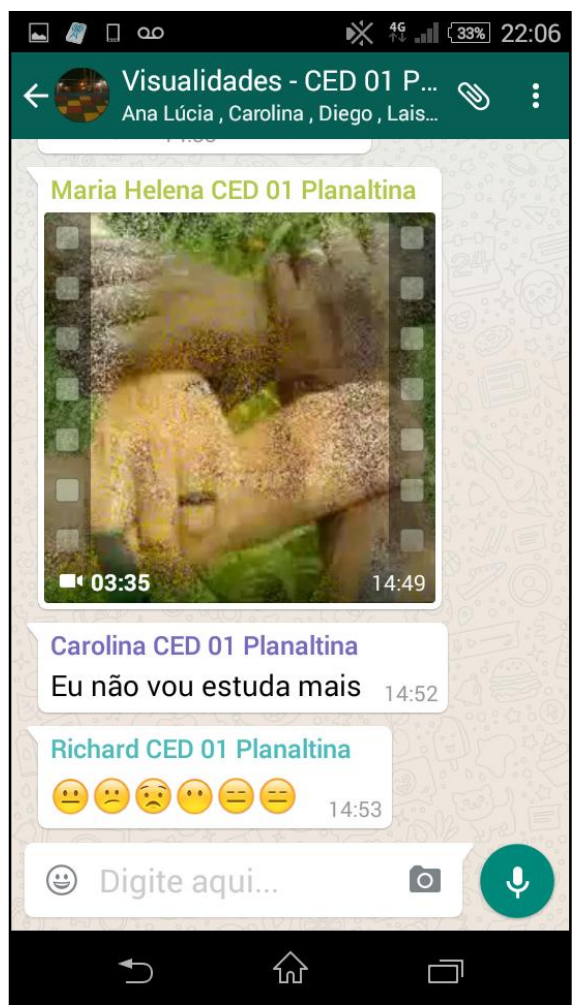

Figura 84. Mensagem do WhatsApp - aluna P-Seis. CED 01 de Planaltina-DF, 2015. 


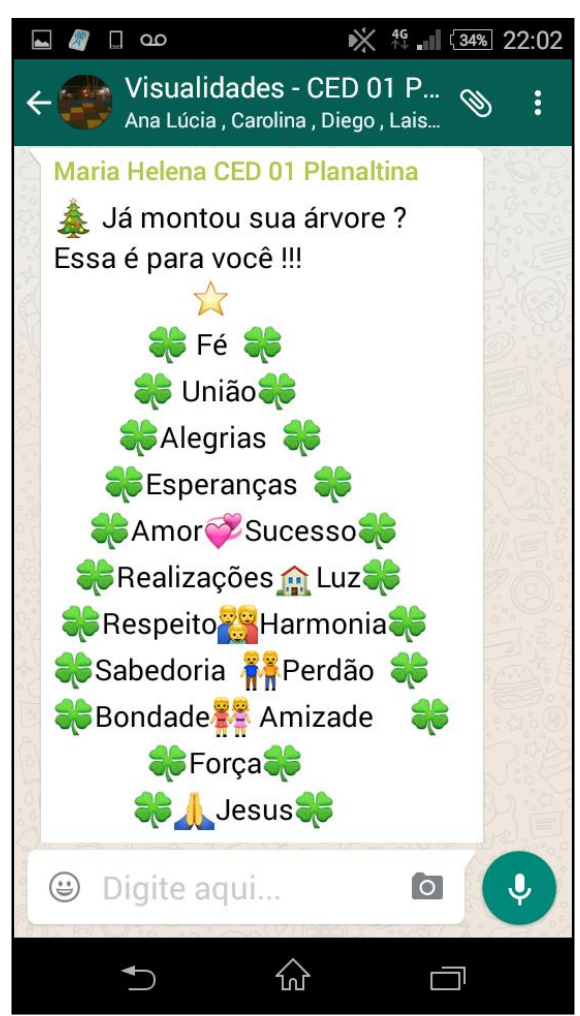

Figura 85. Mensagem do WhatsApp - aluna P-Seis. CED 01 de Planaltina-DF, 2015.

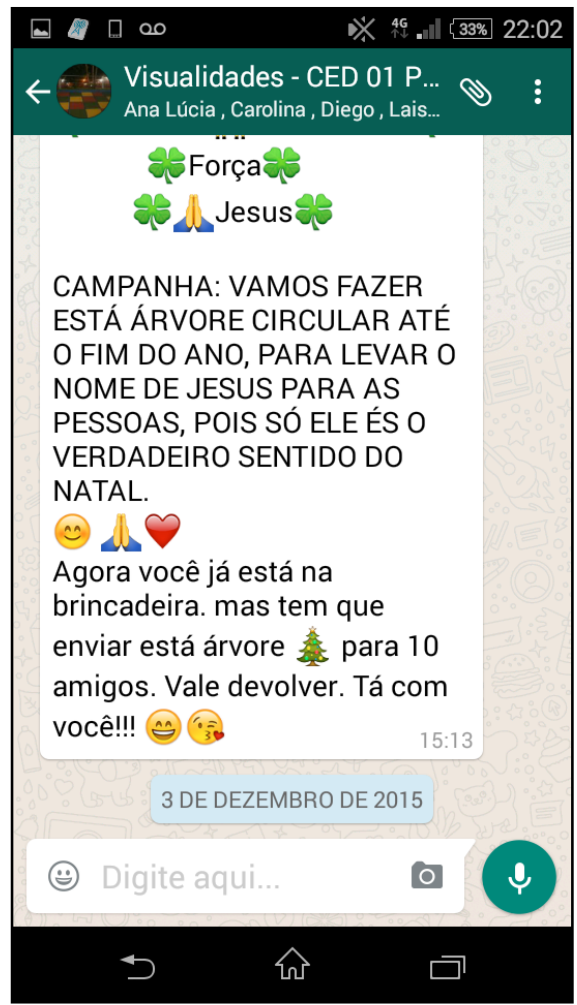

Figura 86. Mensagem do WhatsApp - aluna P-Seis. CED 01 de Planaltina-DF, 2015.

\subsection{Narrativa Visual dos Alunos - CEM 03 de Ceilândia}

O trabalho de pesquisa na perspectiva da cultura visual a partir das narrativas visuais dos alunos do Centro de Ensino Médio 03 de Ceilândia apresenta as produções de treze alunos que participaram dos quatro momentos da prática pedagógica e suas respectivas expressões do espaço urbano da cidade de Ceilândia.

\subsubsection{Narrativa Visual - Aluno C-Treze}

A narrativa visual a seguir, figura 87 , desenho a lápis, apresenta no céu um sol com boca e olhos e algumas nuvens, entre o céu e a terra vários pássaros voando e na terra, um espaço dividido entre casas, edifícios e carros. Nesse ambiente densamente povoado, restam poucos espaços para as brincadeiras infantis. Mesmo assim, as crianças encontram um terreno baldio para jogar futebol ou um espaço para soltar pipa. Essa dinâmica é o que Augé (2012) denomina cultura urbana, os modos dos habitantes estarem na cidade, os modos como eles experimentam a dinâmica sociocultural do espaço que habitam. É o que podemos compreender da narrativa do aluno em um contexto urbano que predomina a ausência de espaço para as brincadeiras infantis; no entanto, as crianças encontram entre prédios, postes 
da rede elétrica urbana, ruas e carros, entre becos e trânsitos, espaço para brincadeiras demonstrando que, ao mesmo tempo em que as estruturas urbanas impõem massificação, possibilitam a diversificação e a pluralidade.

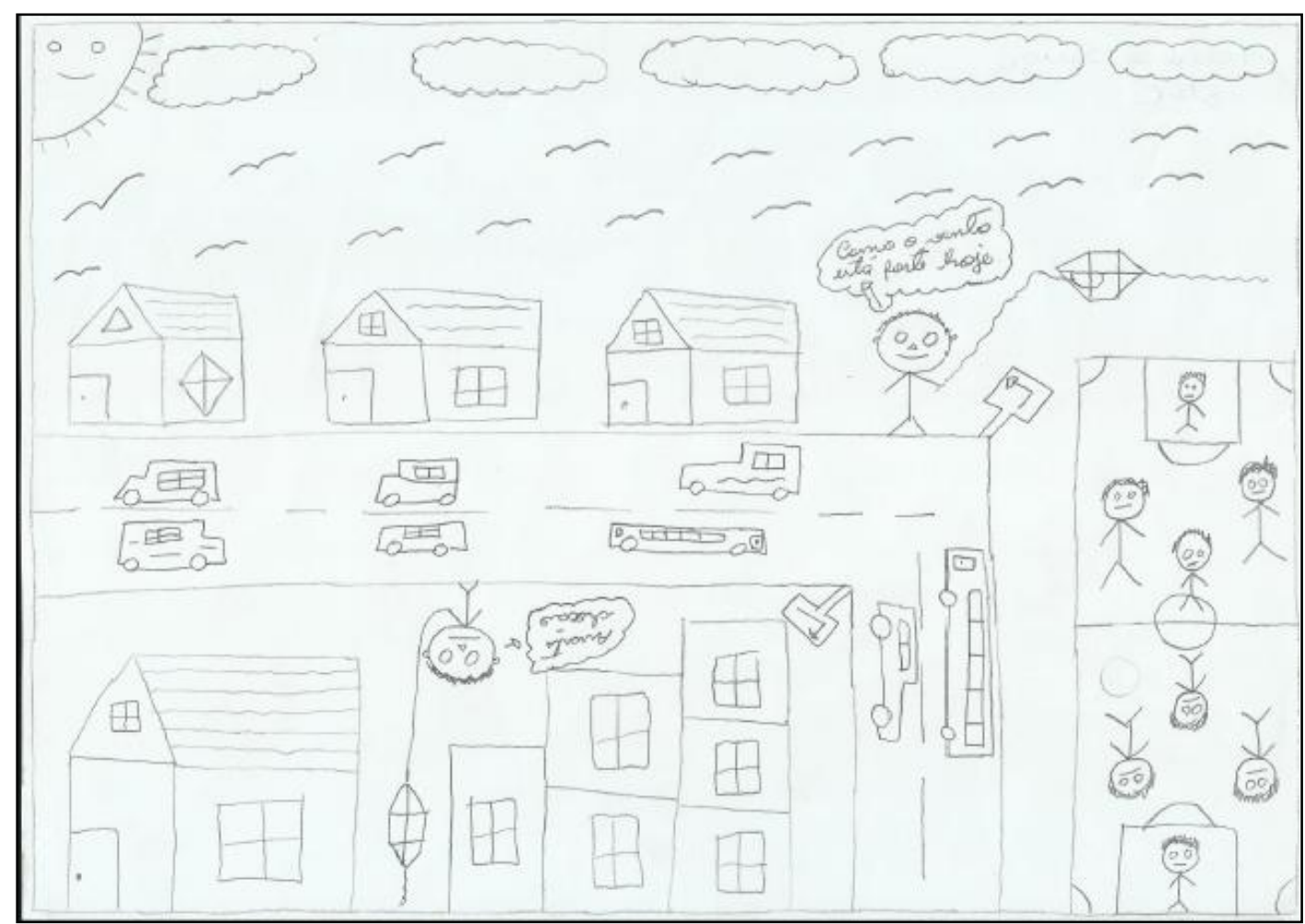

Figura 87. Lugares de lembrar a infância - aluno C-Treze. CEM 03 de Ceilândia-DF, 2015.

Já a narrativa visual do aluno sobre a cidade, figura 88, apresenta novamente um desenho a lápis, com a utilização de alguns tons de azul, roxo, lilás e amarelo. O desenho descortina uma estrutura urbana da cidade em que as pessoas e as atividades se concentram no mesmo espaço. Prédios altos são construídos ao lado de prédios baixos. O terreno consiste numa longa pista para carros que os alunos deveriam atravessar para chegar à escola.

De um lado, fica a escola e do outro lado, não muito distante um do outro, funciona o bar e a farmácia. Com o seu olhar do alto, o aluno desvela a inadequação que se delineia na paisagem urbana da cidade. Muito mais do que a falta de critérios na construção dos prédios, a representação desvela como as populações pobres são empurradas para as periferias, o que faz da Ceilândia um espaço de expansão da pobreza, de segregação espacial e de criação de periferias da periferia ${ }^{45}$.

45 Exemplo da criação de periferia de periferia é o condomínio Sol Nascente, localizado na Ceilândia, considerado a maior favela da América Latina, ultrapassando a Rocinha e as comunidades carentes em Buenos Aires na Argentina e La Paz na Bolívia. Segundo dados do IBGE a população do Sol Nascente é de 78.912 moradores. 


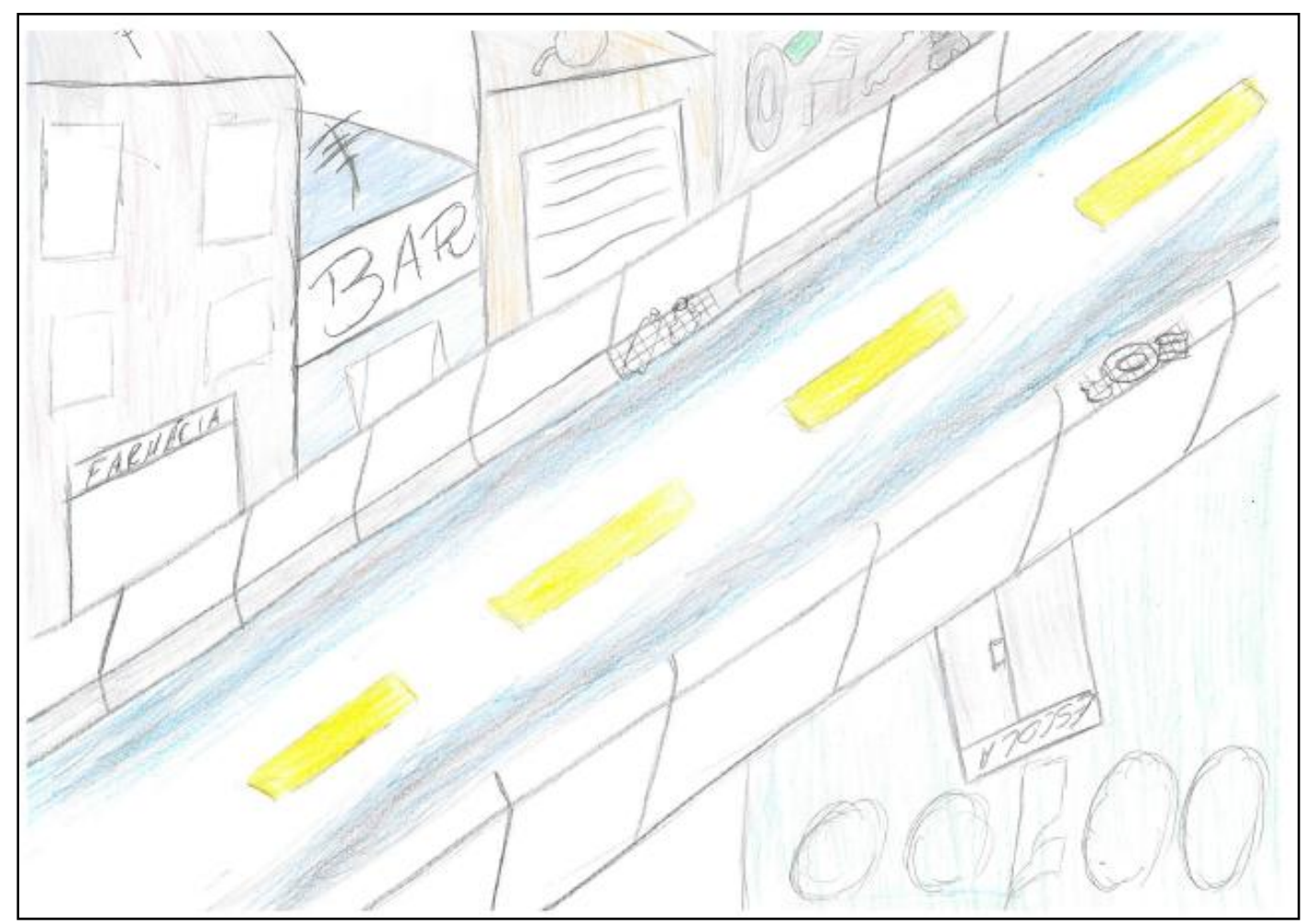

Figura 88. Lugares de lembra a cidade - aluno C-Treze. CEM 03 de Ceilândia-DF, 2015.

Nessas periferias, a cidade é caótica, poluída e desorganizada. Um ambiente denso com ruas estreitas. A narrativa sugere que o fluxo de pedestres é inconsequente e imprudente.

A narrativa do aluno C-Treze nos remete ao trabalho desenvolvido por Ramos (2008) O Intestino da cidade, propondo olhar o âmago dos subúrbios, das favelas como parte do movimento peristáltico de um grande intestino da cidade de Salvador. Segundo a autora,

\begin{abstract}
Nosso propósito foi reunir diversas linguagens pictóricas diferentes e olhares, que pudessem traduzir plasticamente, os movimentos peristálticos deste grande intestino urbano que nos digere, transformando-nos a cada instante. As cidades incham devido à má digestão social, pois não suportam o crescimento desordenado, causando explosão demográfica, desigualdade social, excrementando em conflitos e violências. Atingindo inclusive o meio ambiente que vem sendo poluído e degradado. Nestas exposições o intestino da cidade está representado por obras constituídas de matéria e poesia ainda que carregadas, de memórias contando histórias de um passado ainda presente, hora nas ruínas do centro histórico ou nas favelas impregnadas de trapos e lágrimas. As ruas de nossa cidade representadas pelas vísceras, carregadas de feridas abertas no coração do povo (RAMOS, 2008, p. 22).
\end{abstract}

A experiência resultou em diversas exposições ocorridas no Recôncavo Baiano e em Salvador. 
Acerca de seus sonhos e expectativas futuras o aluno, figura 89, como todo ser humano, deseja um futuro digno e a realização do sonho de conhecer outras culturas dentro e fora do país.

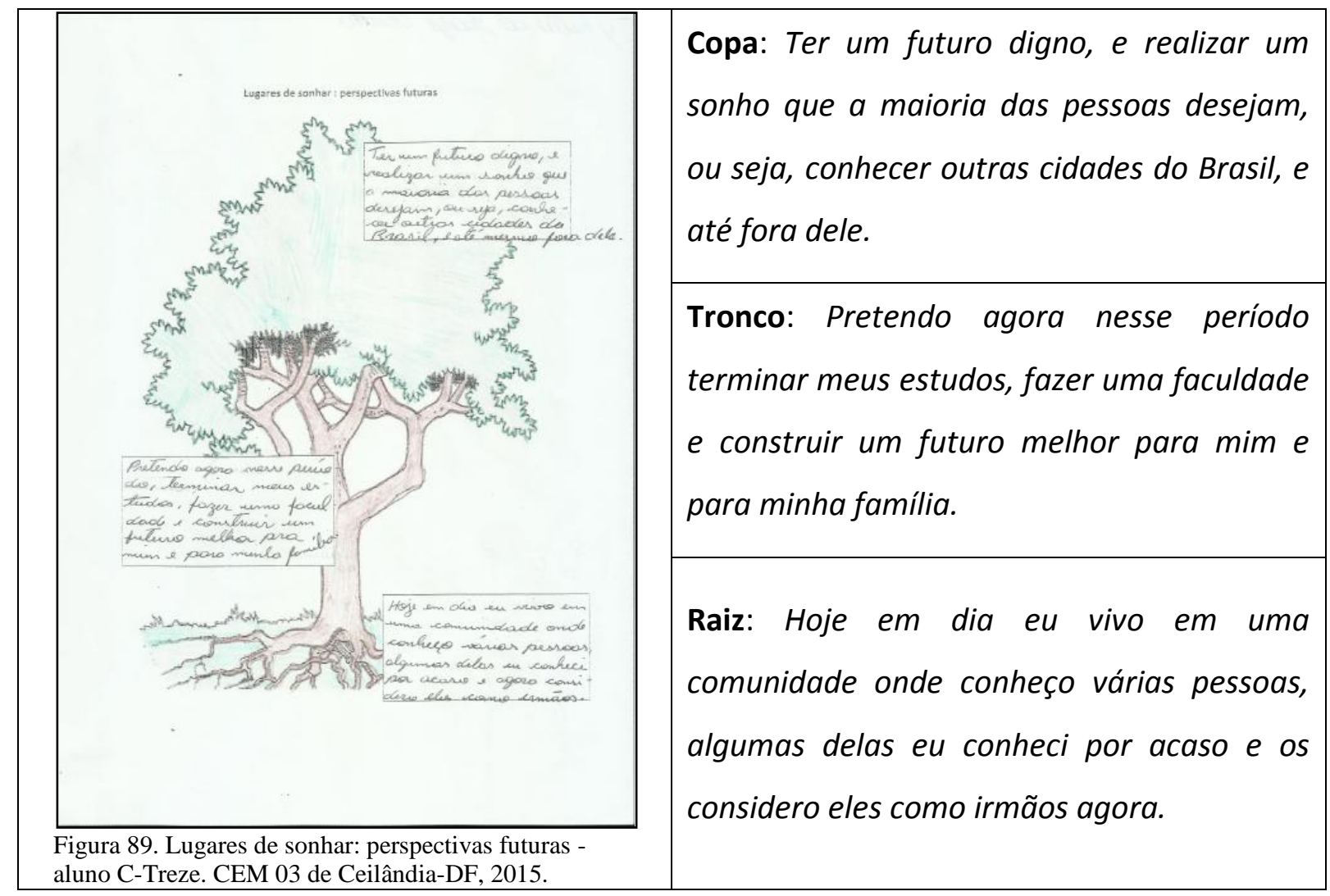

A intenção do aluno é terminar o ensino médio, fazer uma faculdade e construir um futuro melhor para sua família. Na base de suas perspectivas está a amizade das pessoas da comunidade onde vive, consideradas como irmãos.

Nas imagens enviadas por meio do dispositivo móvel, o aluno remete diversas mensagens com fotografias e representações do espaço urbano, evidenciando a cidade de Ceilândia na atualidade com seus monumentos representativos.

A primeira imagem é a caixa d’água, figura 90, considerada o cartão postal da Ceilândia. Com cerca de 30 metros, o reservatório foi inaugurado em dezembro de 1974, tornando-se um marco em uma cidade recém-criada e com poucas edificações. Para Luciene dos Santos Velez ${ }^{46}$, a caixa d'água é um símbolo do sentimento de pertencimento; representado como ícone da memória da construção. O processo de tombamento foi iniciado

\footnotetext{
${ }^{46}$ Pompeu, Ana. "Cercada de história e simbologia, caixa d'água de Ceilândia é tombada". Correio Braziliense, 21/11/2013.
} 
em 2011, pela iniciativa do Fórum de Cultura de Ceilândia, alegando que a especulação imobiliária poderia ameaçar este símbolo representativo da história da cidade.



Figura 90. Mensagem do WhatsApp - aluno C-Treze. CEM 03 de Ceilândia-DF, 2015.

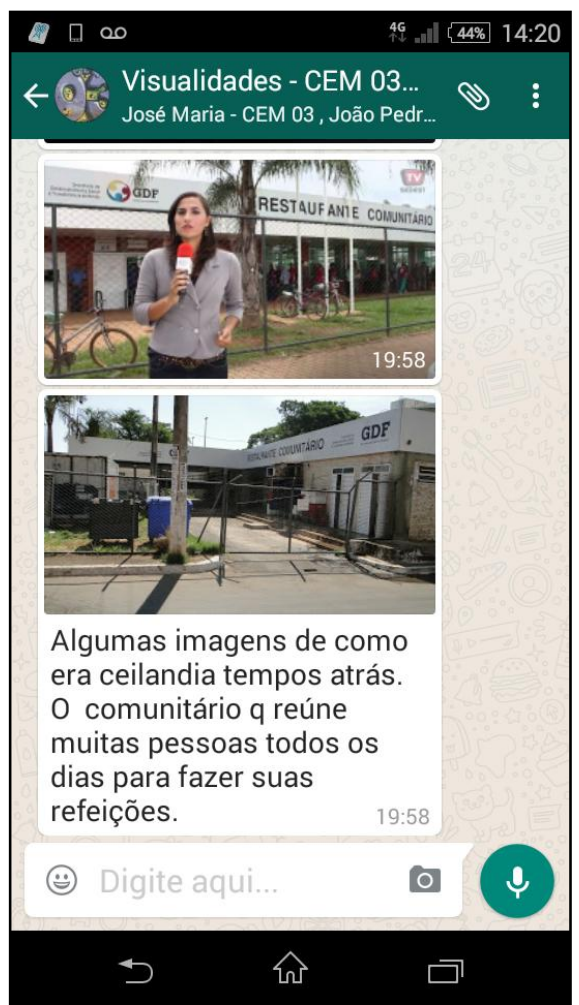

Figura 91. Mensagem do WhatsApp - aluno C-Treze. CEM 03 de Ceilândia-DF, 2015.

As demais imagens são referências ao Restaurante Comunitário, popularmente conhecido como "Rorizão"47 ou "Bandejão", figuras 90 e 91. Inaugurado em julho de 2002, o espaço é responsável pelo preparo e venda a preços acessíveis, de refeições saudáveis à população de baixa renda e em situação de vulnerabilidade social.

As demais imagens enviadas pelo aluno são apresentadas, na figura 92, a feira de Ceilândia ao fundo a Caixa D’água e a sede do Ceilândia Esporte Clube - a agremiação esportiva, fundada em 1979, sediada na cidade de Ceilândia, tendo como arena o estádio Maria de Lourdes Abadia ${ }^{48}$, conhecido como "Abadião".

Outra imagem vislumbra uma partida de dominó ao ar livre, figura 93. O jogo de dominó é jogado com 28 peças, divididos entre quatro jogadores, sentados face a face em torno de uma mesa. As peças são retangulares e possuem uma marcação que as divide em duas metades iguais: em cada metade está gravado ou não um determinado número de

\footnotetext{
${ }^{47}$ Homenagem ao político Joaquim Domingos Roriz, que exerceu a função de governador do DF por quatro mandatos.

${ }^{48}$ Maria de Lourdes Abadia foi Administradora Regional de Ceilândia durante 14 anos. Em 1987 foi eleita deputada federal, em 1995 foi nomeada secretária de Turismo do DF, e em 2002 foi eleita vice-governadora do DF. Fonte: http://www.brasil.gov.br/. Acesso em jul/2016.
} 
buracos que representam números. É um jogo coletivo, conhecido por crianças e adultos, estando diretamente relacionado ao pensamento matemático (regras, instruções, operações, definições, deduções, desenvolvimento, utilização de preceitos e operacionalizações), pautado na interação que permite momentos de comunicação e construção de informações compartilhadas (Brenelli, 1996). Na Ceilândia esses jogos ocorrem nas sombras das árvores, envolvendo a comunidade representada por aposentados, taxistas, vendedores e outras pessoas que interagem enquanto jogam.

Ainda na mesma mensagem, figura 93, a outra imagem é apresentada a Casa do Cantador, edificação criada pelo arquiteto Oscar Niemeyer com a intenção de homenagear a comunidade nordestina, considerada em maior número de habitantes na cidade.

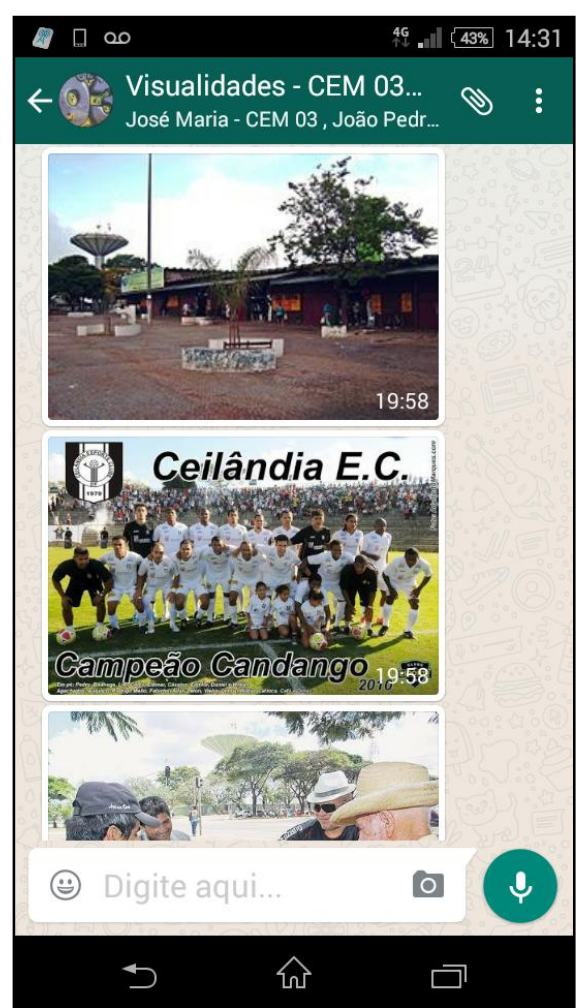

Figura 92. Mensagem do WhatsApp - aluno C-Treze. CEM 03 de Ceilândia-DF, 2015.

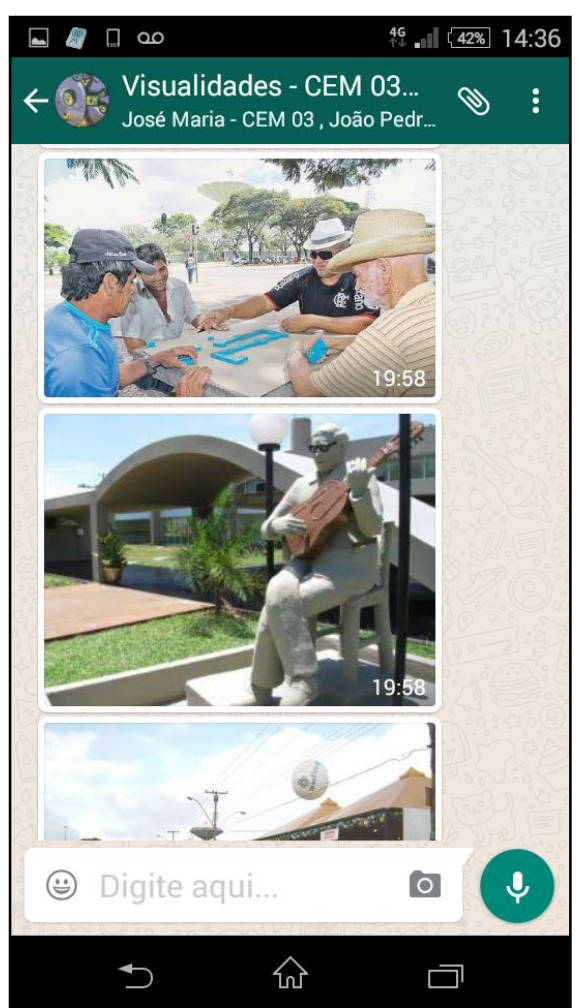

Figura 93. Mensagem do WhatsApp - aluno C-Treze. CEM 03 de Ceilândia-DF, 2015. 




Figura 94. Mensagem do WhatsApp - aluno C-Treze. CEM 03 de Ceilândia-DF, 2015.

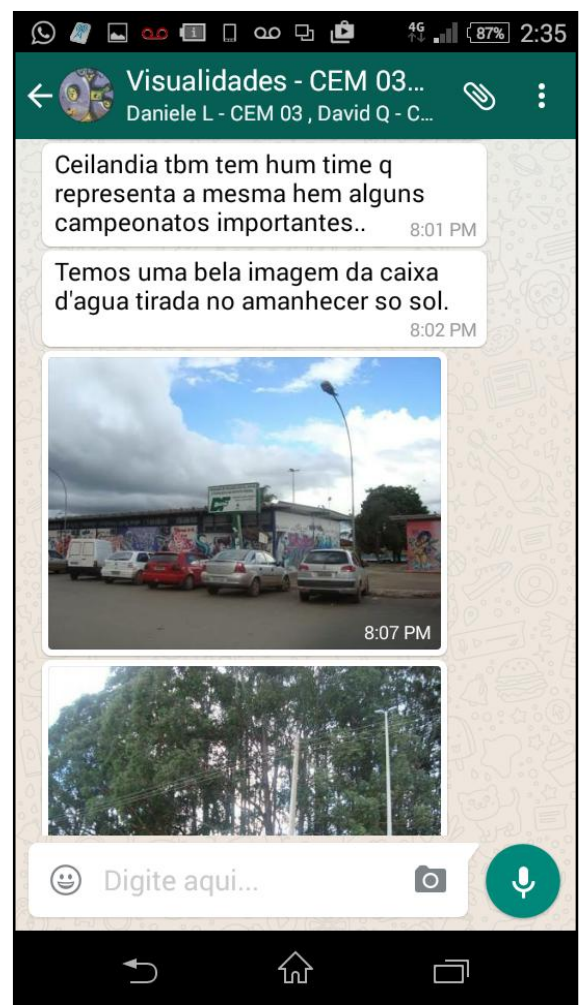

Figura 96. Mensagem do WhatsApp - aluno C-Treze. CEM 03 de Ceilândia-DF, 2015.

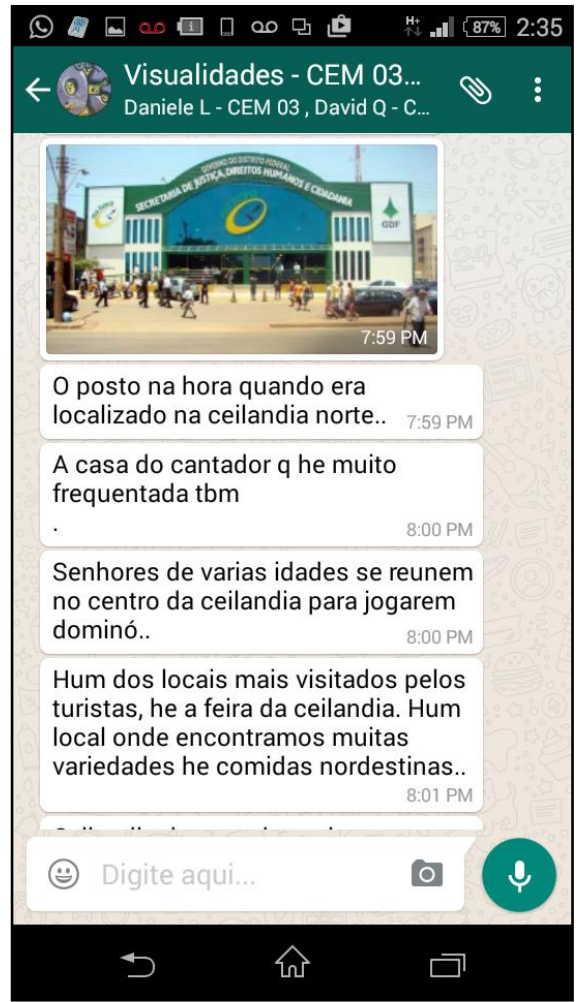

Figura 95. Mensagem do WhatsApp - aluno C-Treze. CEM 03 de Ceilândia-DF, 2015.

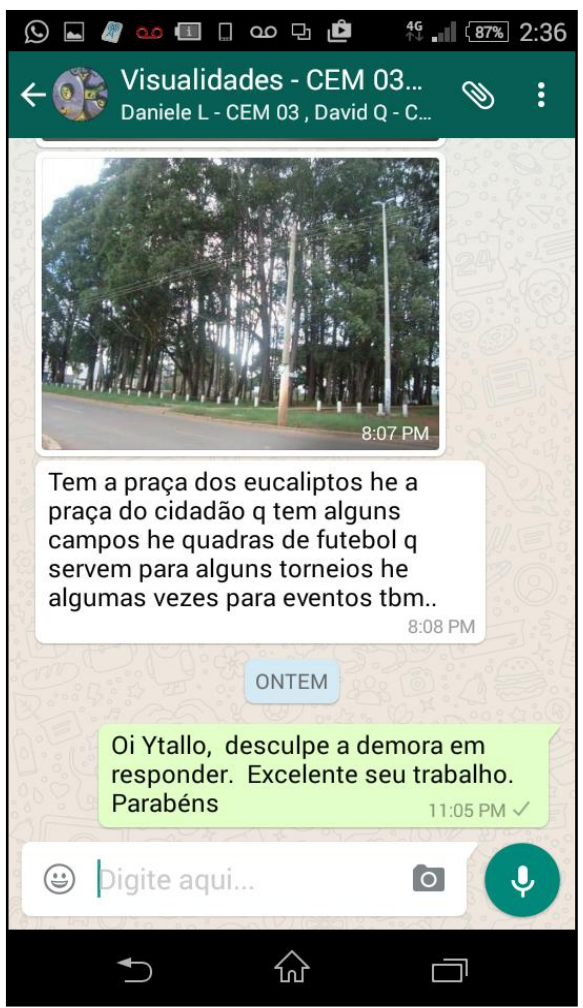

Figura 97. Mensagem do WhatsApp - aluno C-Treze. CEM 03 de Ceilândia-DF, 2015.

Em seguida, a imagem da Feira da Ceilândia com 460 boxes, figura 94, que é conhecida como ponto de encontro e referência na comunidade. Como na letra da música: "a 
feira da Ceilândia te oferece o que quiser comprar: peixe, sapato, retrato, colar pra te enfeitar" ${ }^{\prime \prime}$.

Outra paisagem deixa entrever a unidade do "Na Hora", figura 95, espaço da Secretaria de Justiça, Cidadania e Direitos Humanos, criado em 2001, com o objetivo de reunir num só local, diversos órgãos federais e distritais, para atendimento ao cidadão.

A Praça dos Eucaliptos, figura 96 e 97 é um espaço que possui uma área extensa com grande quantidade de árvores de eucaliptos, ponto de encontro da comunidade de Ceilândia Norte, com calçadas para caminhada, campo de futebol com arquibancadas, quadra de voleibol de areia. Conhecida também por sua pista de skatistas e ciclistas, a praça é um espaço de encontro de esporte e cultura.

\subsubsection{Narrativa Visual - Aluno C-Dez}

Na produção da narrativa do aluno C-Dez vem a imagem da brincadeira infantil da pipa, figura 98. Sabemos que no Brasil, empinar pipas é uma brincadeira popular entre crianças e jovens. Em alguns lugares a pipa recebe outros nomes dependendo da região do País: arraia (Bahia), pipa (Rio de Janeiro), papagaio e pipa (São Paulo), pandorga (Paraná, Rio Grande do Sul e Santa Catarina), quadrado, tapioca, balde (Nordeste). As pipas são feitas basicamente por duas varetas cruzadas em xis, com suas extremidades unidas por barbante, cordão ou fio fino tipo nylon, cola e papel de seda.

\footnotetext{
${ }^{49}$ Ellen Oléria. Senzala (A Feira da Ceilândia)
} 


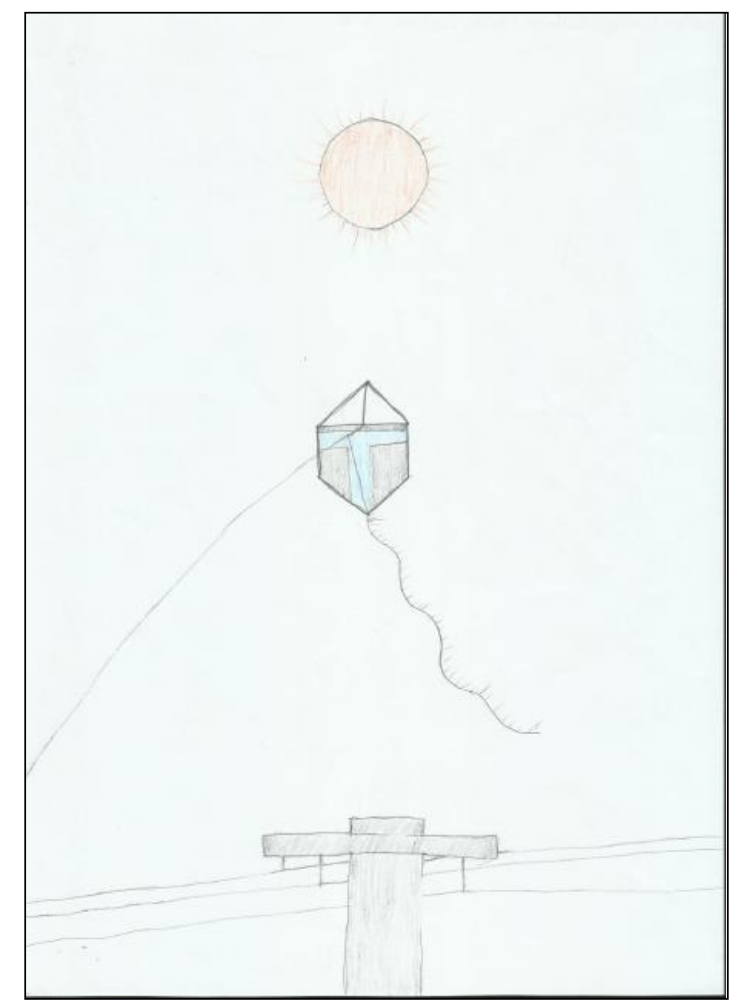

Figura 98. Lugares de lembrar a infância - aluno CDez. CEM 03 de Ceilândia-DF, 2015.

$\mathrm{Na}$ narrativa do aluno, o dia está ensolarado e possivelmente ventando muito, o que propicia a brincadeira de pipa. No entanto, a rede elétrica indica que a brincadeira pode ser perigosa. A narrativa do aluno é reveladora de que o ato de brincar é também representativo da desigualdade social, visto que uns brincam com o que desejam brincar, outros brincam com o que têm e principalmente, com o que não têm, deixando aflorar a inventividade e a criatividade de suas ações ao brincar.

A sua narrativa remete também aos estudos do geógrafo brasileiro Milton Santos (1986, 1987) onde aponta as contradições presentes nas cidades contemporâneas como locais de desenvolvimento e progresso, mas também lugares de problemas sociais. Para o autor, o espaço urbano é diferentemente ocupado em função das classes em que se divide a sociedade urbana, os homens se dividem no espaço de maneira distinta, e o lugar que ocupam é um dado fundamental para a reprodução das desigualdades entre eles.

Demonstra também, que as crianças, em suas brincadeiras, apreendem a cultura e dão novos sentidos a ela. Brincadeiras como soltar pipa são consideradas populares e ainda ocorre e não vão desaparecer com o consumo de brinquedos industrializados e individualizados.

Da observação de sua narrativa podemos interpretar que apesar da precariedade dos espaços urbanos, as crianças criam suas próprias estratégias para brincar, desafiando as limitações sociais, econômicas e espaciais. 
Na sua narrativa sobre a cidade, figura 99, o aluno apresenta duas imagens: uma da época da construção de Brasília e a outra da cidade de Ceilândia com problemas comuns à cidade grande como a falta de estacionamentos. Em sua narrativa, o aluno compara o momento da construção, quando as pessoas chegavam em caminhões chamados de pau de $\operatorname{arara}^{50}$ e atualmente a cidade de Ceilândia tendo que conviver com o excesso de automóveis e a ausência de estacionamentos.



Figura 99. Lugares de lembrar a cidade e sua inserção - aluno C-Dez. CEM 03 de Ceilândia-DF, 2015.

Sabemos que a indústria de automóveis foi um marco na história da industrialização brasileira. Foi concretizada em 1956, com a eleição de Juscelino Kubitschek à presidência e o Plano de Metas que tinha como objetivo levar o Brasil a crescer cinquenta anos em cinco. Nesse período, foi conduzido o projeto para implantação da produção nacional de veículos. Atualmente, a produção nacional é a quarta maior do mundo, justificando o caos no trânsito nas cidades brasileiras.

Atualmente, os automóveis invadem grande parte dos espaços públicos, desvelando a ineficiência dos sistemas de transporte coletivo e fazendo com que os espaços públicos das

\footnotetext{
${ }^{50}$ Transporte irregular que consiste em caminhões adaptados para o transporte de passageiros, muito utilizados durante a migração dos nordestinos para o Sudeste e Centro-oeste do país.
} 
cidades sejam negligenciados e substituídos por estacionamentos e congestionamento de veículos, afetando o nível de interação social da comunidade.

A narrativa do aluno destaca o entendimento da cidade como um tecido urbano em plena mutação, com um território densamente ocupado, que possui um número muito pequeno de espaços vazios como praças, espaços públicos e livres, que são insuficientes para uma cidade que cresceu rapidamente divergindo das necessidades de sua população.

Sobre as suas perspectivas futuras, figura 100 a seguir, o aluno reafirma a degeneração dos espaços da cidade ao afirmar que sonha com a cidade limpa porque é possível encontrar lixo nos espaços vazios da cidade. Além do sonho de ver o crescimento da cidade de forma sustentável e igualitária, o aluno deseja ter uma formação superior para cuidar bem da família e ser um exemplo para os filhos.

O aluno demonstra a preocupação com a cidade ao falar do lixo jogado na rua e no número de pessoas drogadas perambulando pela cidade. A narrativa do aluno aponta para a exposição da miséria nos espaços públicos, fenômeno urbano que se amplia nas grandes cidades brasileiras e que transforma as ruas em espaços de construção de fronteiras econômicas, políticas e culturais. Possivelmente o aluno não consiga perceber os limites dados pelo contexto social de origem e nem consiga ver a sua condição na sociedade como construída e não como natural.

A base de seus sonhos e perspectivas está firmada em Deus, na família e nos estudos. 


\begin{tabular}{|c|l|l|}
\hline & $\begin{array}{l}\text { Copa: como já falei meu sonho e ver a } \\
\text { Cidade limpa, porque todo lugar ermo para } \\
\text { a população e lugar de jogar lixo. Outro } \\
\text { sonho e me formar ter um curso superior e } \\
\text { cuidar bem da minha familia dar um bom } \\
\text { exemplo para meus filhos. }\end{array}$ \\
& $\begin{array}{l}\text { Tronco: Algumas ações que faltam ser } \\
\text { concretizada são varias em primeiro eu me } \\
\text { formar, em segundo ver minha cidade limpa } \\
\text { e sem este tanto de drogado que perambula } \\
\text { pela cidade dando mal exemplo. }\end{array}$ \\
& $\begin{array}{l}\text { Raiz: Estou firmado em primeiro em Deus } \\
\text { porque através dele consegui uma estrutura } \\
\text { na fé para seguir em frente, conquista uma } \\
\text { familia e realizar meus sonhos que esta } \\
\text { quase se pagando. Perceber que posso ir } \\
\text { muito mais além com Deus e os estudos. }\end{array}$ \\
\hline $\begin{array}{l}\text { Figura 100. Lugares de sonhar: perspectivas futuras - } \\
\text { aluno C-Dez. CEM 03 de Ceilândia-DF, 2015. }\end{array}$
\end{tabular}

Os estudos sobre a Cultura Visual problematizam a forma como os diversos tipos de imagens perpassam a vida social cotidiana, para então compreender a visualidade urbana e as representações da cidade elaboradas pelos diferentes grupos e espaços sociais. O aluno C-Dez optou por enviar algumas imagens da cidade, figuras 101, 102, 103 e 104, em seus primórdios: a conversa entre os vizinhos em frente ao barraco, a fila para pegar água e os pedestres na rua enlameada ou empoeirada e a caixa d'água - patrimônio histórico da cidade.

Comparadas com as imagens atuais, é possível identificar o agravamento dos problemas de mobilidade decorrente do forte número de veículos individuais que transitam na cidade. Fato que está diretamente relacionado ao modo como a cidade se constituiu e se reproduziu estruturalmente, resultando na sua configuração atual. 


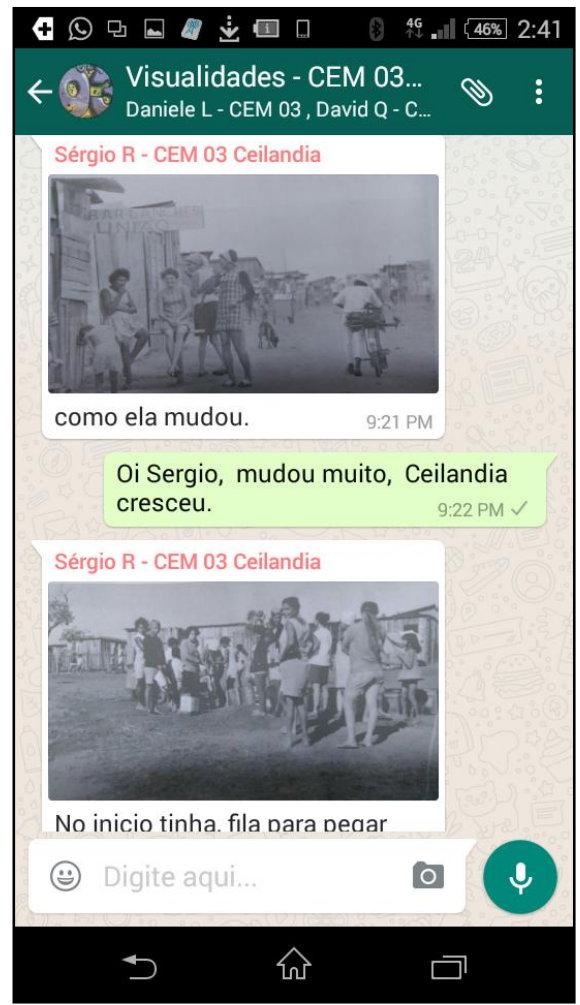

Figura 101. Mensagem do WhatsApp - aluno C-Dez. CEM 03 de Ceilândia-DF, 2015.

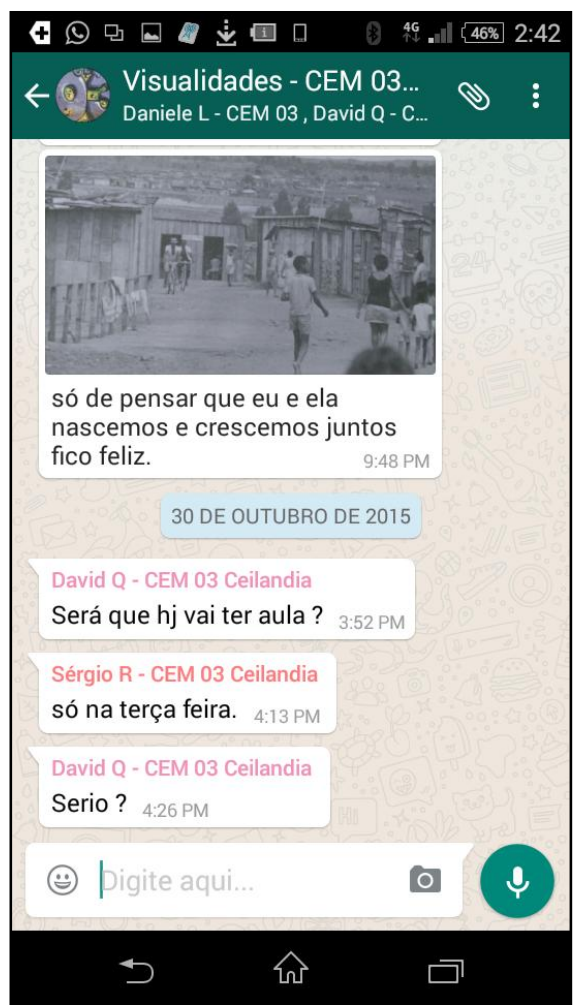

Figura 103. Mensagem do WhatsApp - aluno C-Dez. CEM 03 de Ceilândia-DF, 2015.

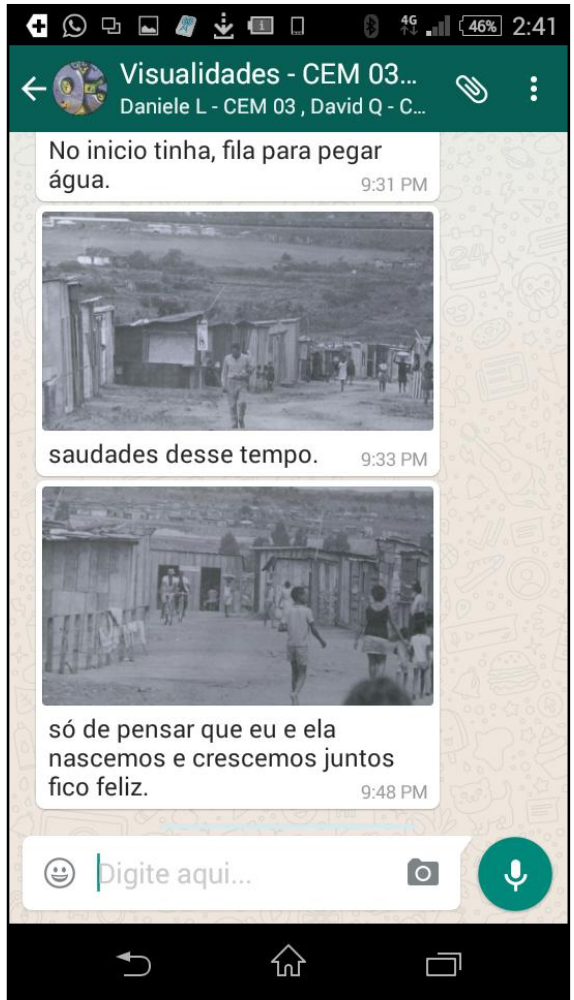

Figura 102. Mensagem do WhatsApp - aluno C-Dez. CEM 03 de Ceilândia-DF, 2015.

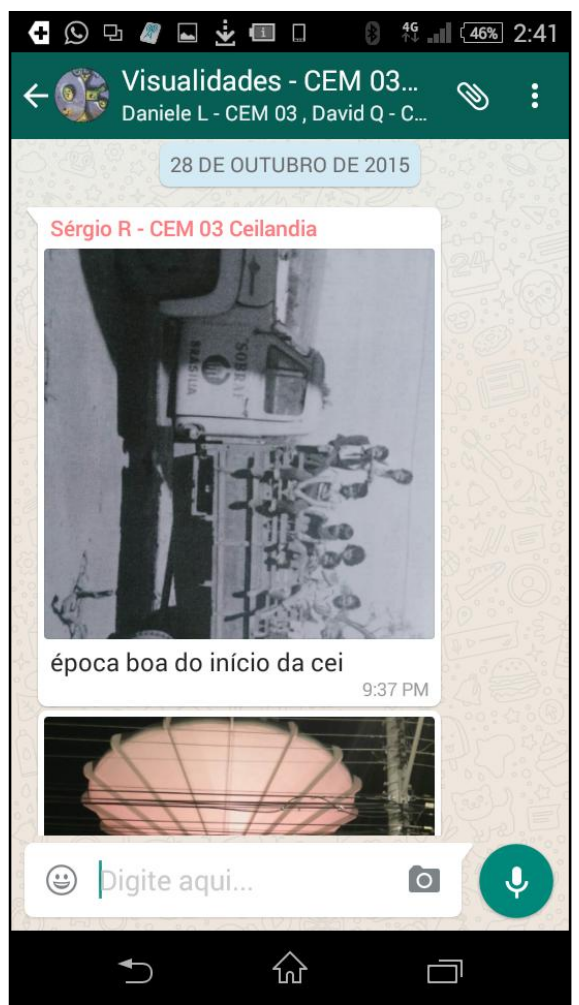

Figura 104. Mensagem do WhatsApp - aluno C-Dez. CEM 03 de Ceilândia-DF, 2015. 
As imagens são reveladoras de um fenômeno da urbanização vivenciado no Brasil ao longo do século XX, especialmente a confluência para a construção da Nova Capital, concentrando oportunidades de trabalho e serviços.

Nas imagens do aluno, as precariedades dos assentamentos evidenciam que são compostos por famílias de baixa renda. A afirmação pode ser observada pelo adensamento e intensidade na ocupação do solo, pela carência de infraestrutura e pela insalubridade da moradia, dada suas dimensões e seu desconforto ambiental.

A narrativa do aluno remete à narrativa visual da cidade de Blumenau, realizada por Silva (2008) onde analisa as imagens da Revista Blumenau em Cadernos, para identificar até que ponto as imagens constantemente repetidas nas edições da Revista serviram como suportes para a formação da memória social sobre a cidade. A autora utiliza como marco o final do século XIX e início do século XX, procurando demonstrar que a cidade eternizada pelo olhar do fotógrafo é representada pelo progresso, tornando-se uma narrativa em que o presente é compreendido como resultado do passado. A conclusão é que as fotografias não apresentam o passado como de fato ele foi, mas sim uma reminiscência conformada na tradição historicista.

\subsubsection{Narrativa Visual - Aluna C-Um}

A narrativa, figura 105, é constituída de um desenho associado à infância. No céu nuvens azuis e um sol amarelo sorridente. Na terra, uma menina de cabelos loiros, olhos azuis, vestido vermelho, colar e sapatos pretos. Neste espaço livre e ensolarado, a criança solta bolinhas de sabão. Brincadeira que ainda hoje encanta as crianças, sendo um excelente recurso para ativar a concentração, além de ser um exercício para os membros superiores, manutenção do equilíbrio e noções de direção, da posição do corpo no espaço e de lateralidade. 


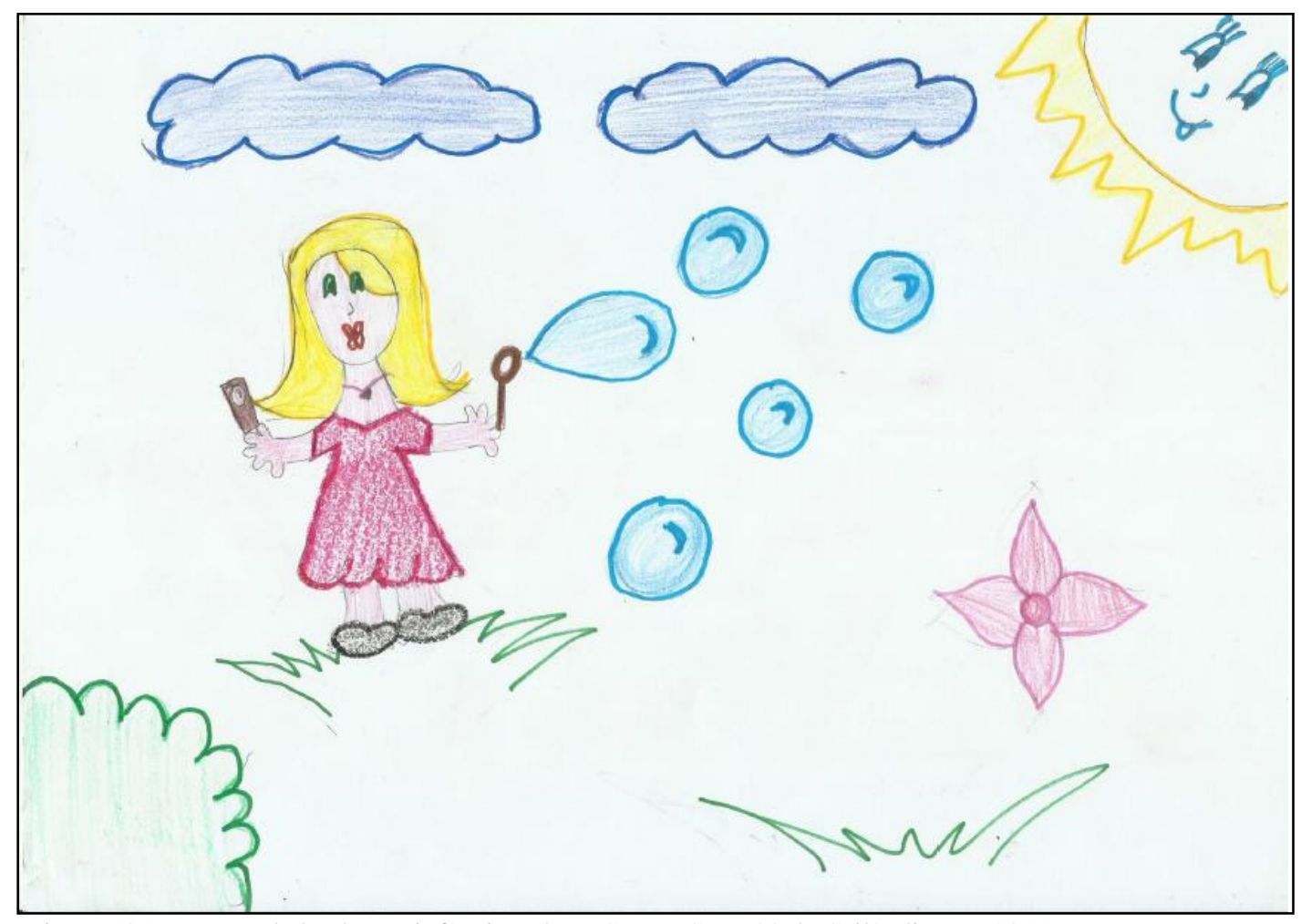

Figura 105. Lugares de lembrar a infância - aluna C-Um. CEM 03 de Ceilândia-DF, 2015.

Chama a atenção à imagem da criança loira, de olhos azuis, colar e comportada como se fosse uma mocinha, diferente da representação comum que se tem da infância, e principalmente da criança no Brasil, herdeira genética de todos os DNAs do mundo.

A narrativa remete ao estudo de Nunes (2010, p. 165), A cultura visual nas tramas escolares: a produção da feminilidade nas salas de aula, no qual a autora observa que as meninas se identificam com suas personagens preferidas nos aspectos físicos e estéticos, na maneira de ser e agir e na incorporação de atitudes sociais como docilidade, meiguice e recato, como apresentadas pela imagem da narrativa. A conclusão da autora é que a cultura visual ensina como devem ser as meninas e como devem se preocupar com o padrão estético de beleza determinado.

A narrativa da aluna sobre a cidade, figura 106, elaborada com colagem de papel jornal intitulada "As noites badaladas de Brasília", enfoca as diversas manifestações musicais da capital, iniciadas na década de 1970, com várias bandas dentre elas: Legião Urbana, Capital Inicial, Plebe Rude e outros, que colocam Brasília no eixo de produção musical.

Esse momento da história musical de Brasília é tema do documentário "Rock Brasília: Era de ouro" dirigido por Vladimir Carvalho. Composto de entrevistas e imagens de arquivo, o documentário mostra um pouco da história da construção cultural e ideológica da Capital Federal. 
A cidade de Ceilândia, rotulada por possuir uma cultura popular típica do sertão nordestino, reproduz eventos como emboladas, poesia matuta, repente e literatura de cordel. $\mathrm{O}$ auge dos eventos musicais é denominado São João do Cerrado ${ }^{51}$ que acontece na cidade no período entre os dias 28 a 30 de agosto, como citado na narrativa da aluna.

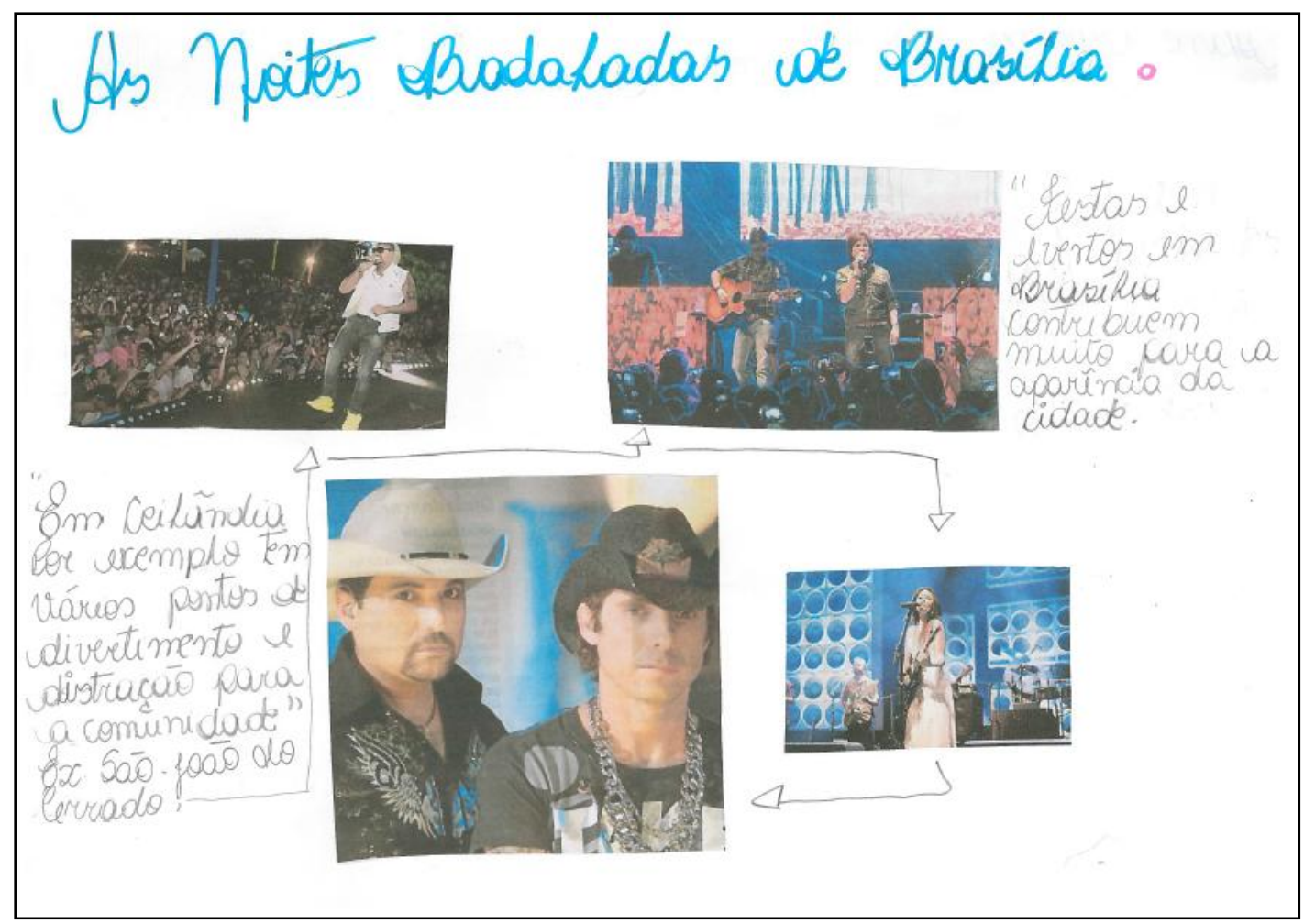

Figura 106. Lugares de lembrar a cidade e sua inserção - aluna C-Um. CEM 03 de Ceilândia-DF, 2015.

A narrativa da aluna ressalta a mistura de identidades culturais existente em Brasília. A cidade é um terreno fértil para o diálogo entre os diversos gêneros, compositores, empresários e intérpretes, com a presença de diferentes estilos e ritmos musicais, novos e velhos numa convivência indicativa de formação de um mercado fonográfico heterogêneo. Do rock ao samba, do axé ao sertanejo, do hip hop à música clássica. A cidade também é destaque na produção cultural e surgimento de novos artistas do break, grafite, rap e discotecagem.

Em suas perspectivas e sonhos, figura 107, a aluna vislumbra a valorização de algumas profissões, a melhoria e barateamento do transporte público, expansão do ensino superior com a criação de mais faculdades, melhores condições de vida e oportunidade para os jovens, principalmente àqueles em situação de vulnerabilidade social.

\footnotetext{
${ }^{51}$ São João do Cerrado é a festa dos amantes da cultura nordestina, conta com shows musicais, forró, parque de diversões, gastronomia nordestina. http://www.saojoaodocerrado.com.br. Acesso em 11 jul/2016.
} 


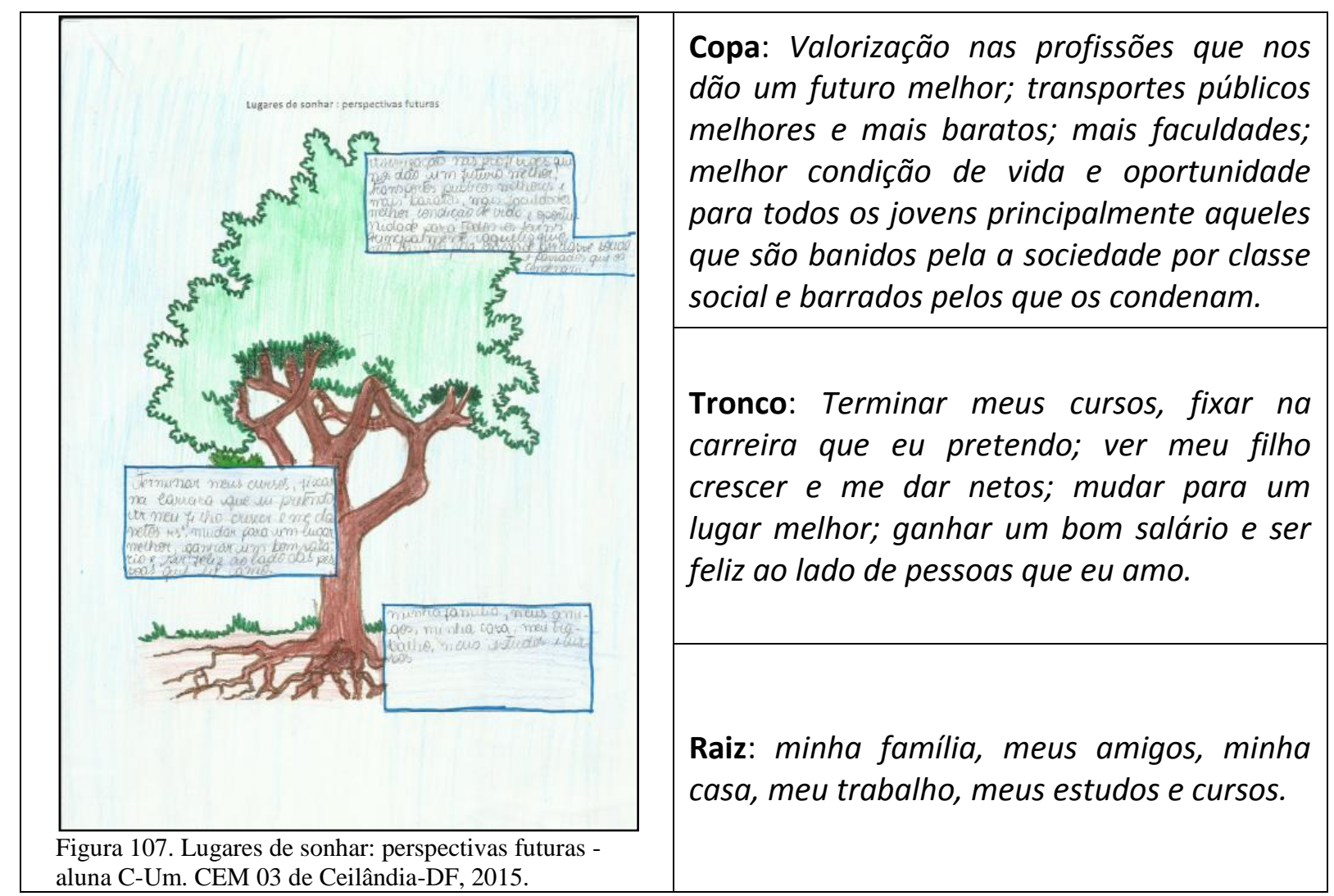

A intenção da aluna é terminar seus estudos, ter uma carreira, ver o seu filho crescer e ter netos. Pretende também mudar para um lugar melhor, ganhar um bom salário e ser feliz ao lado das pessoas que ama.

A raiz de seus sonhos é sustentada pela família, amigos, trabalho e estudo. Cabe lembrar aqui, o estudo de Pereira (2010, p. 209), intitulado Estereótipos desenhados, identidades projetadas. Nesse artigo o autor afirma que as imagens engendram as representações dos sujeitos em termos de classe, gênero, raça/etnia, orientação sexual, faixa etária, dentre outras variáveis. O estudo nos leva a compreender que o texto da aluna produz uma espécie de diagnóstico da relação de poder existente na sociedade brasileira.

Nessa relação de poder, a aluna constrói o significado a partir da busca da homogeneização da sua identidade com aqueles que ascendem socialmente através do estudo. Entretanto, escamoteia a herança da escravidão e suas consequências para a evolução do sistema educacional, já que a abolição tardia da escravidão está relacionada à manutenção de tecnologias primitivas e formas tradicionais de trabalho e dominação. Nesse contexto, a escola não é vista como instrumento para a melhoria da situação de vida, nem instrumento de mobilidade social, a não ser para camadas privilegiadas da população. 


\subsubsection{Narrativa Visual - Aluno C-Oito}

A narrativa é constituída por um desenho, figura 108, de um campo de futebol, com traços fortes, na cor preta. O campo de futebol retratado pelo aluno está vazio e possui duas partes de diferentes cores passando a impressão de uma estrutura inacabada, ainda em construção ou uma alusão ao futuro em relação ao passado da cidade de Ceilândia.

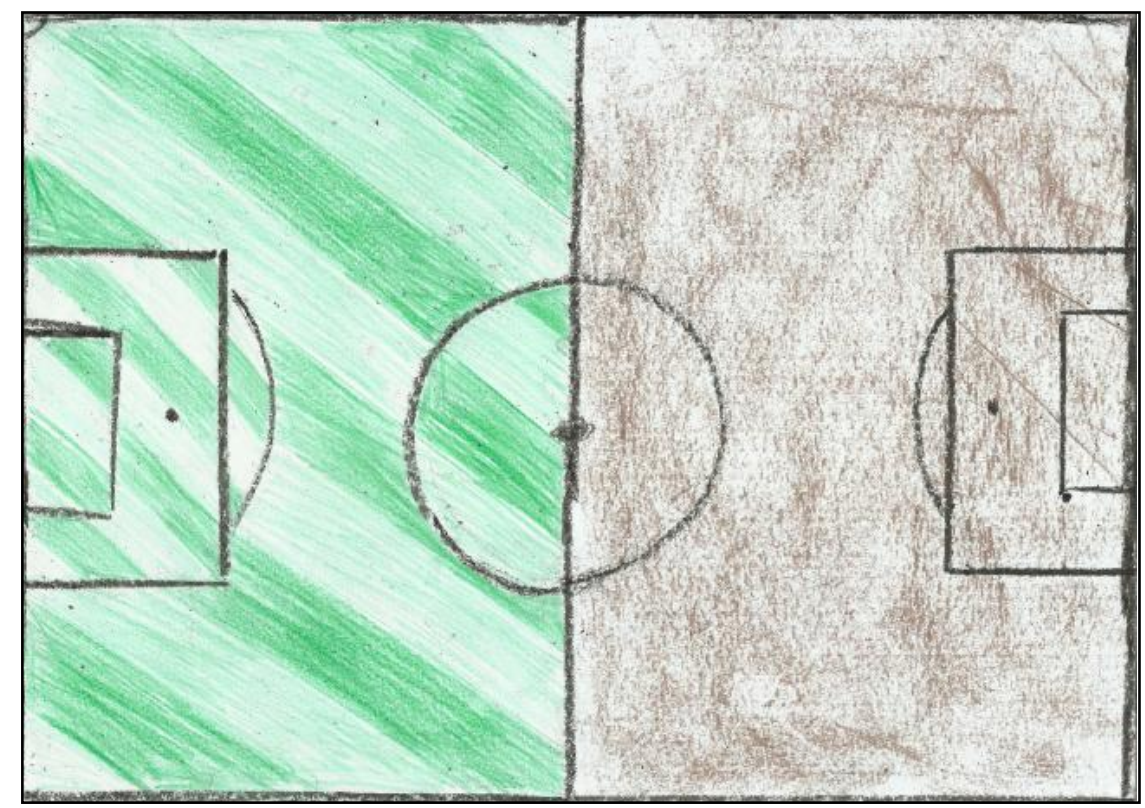

Figura 108. Lugares de lembrar a infância - aluno C-Oito. CEM 03 de Ceilândia-DF, 2015.

Estudos acerca do futebol demonstram que ele exerce um sentimento de paixão e idolatria que extrapola os limites do esporte e passa a ser parte integrante do meio social. A importância do futebol para a população brasileira é evidenciada nas diferentes manifestações culturais, como literatura, cinema, dramaturgia, música e artes plásticas. Além da expressão linguística, o futebol interfere na expressão corporal do brasileiro ${ }^{52}$.

Em suas narrativas sobre a cidade, figura 109, o aluno se apropriou dos emoticons do whatsApp para avaliar as instituições e os espaços públicos da cidade, ficando evidente o descontentamento com os serviços públicos e aprovando os espaços interativos, como a Feira de Ceilândia e o Parque de Diversões.

\footnotetext{
52 Ver Stein, Leandro. Como o futebol moldou a identidade cultural do brasileiro, disponível em http://trivela.uol.com.br/como-o-futebol-moldou-a-identidade-cultural-do-brasileiro/, $\quad$ acesso em 15 de agosto/2016.
} 


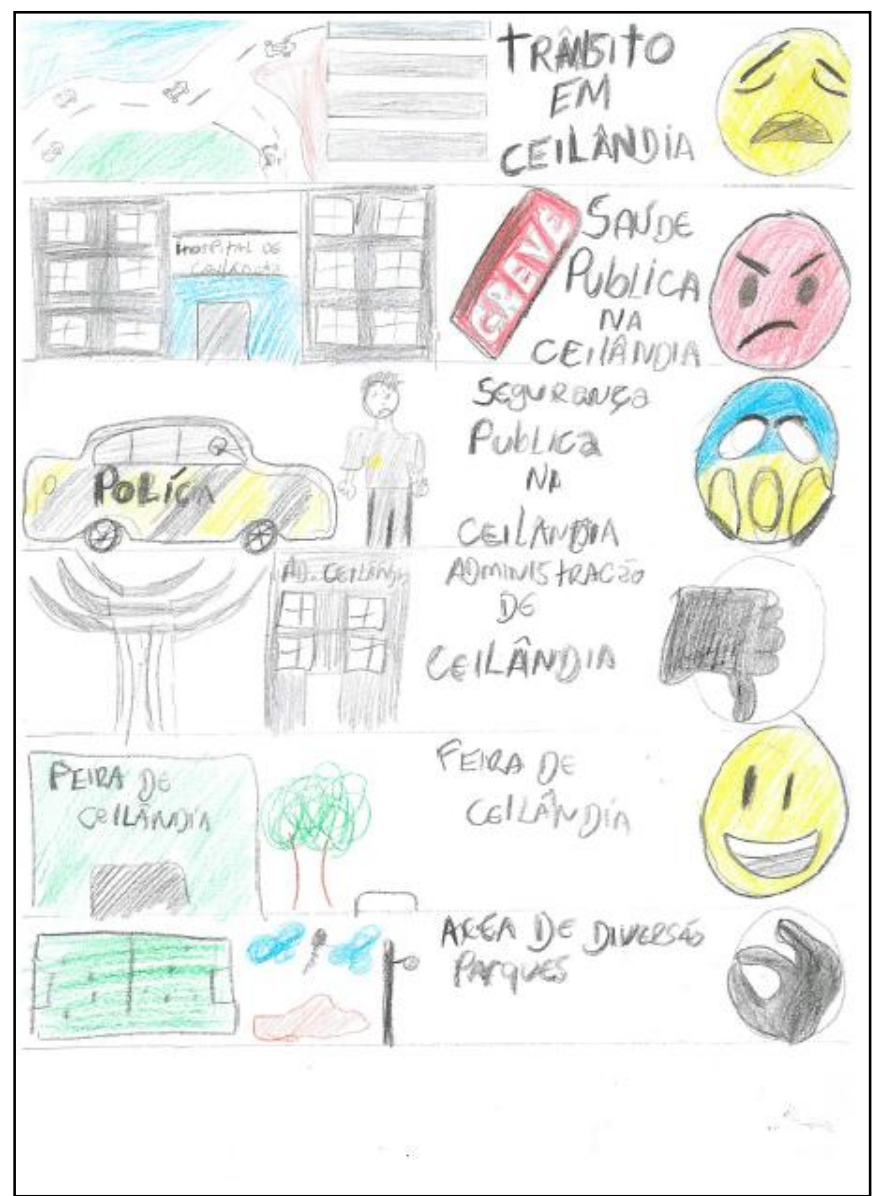

Figura 109. Lugares de lembrar a cidade e sua inserção - aluno C-Oito. CEM 03 de Ceilândia-DF, 2015.

A narrativa parece indicar que parte dos brasileiros não confiam em seus governos, tribunais de justiça, política e serviços de saúde e educação. Pesquisas realizadas por Moisés (1995, 2005) revelaram que a percepção negativa das instituições atravessa todos os segmentos de renda, escolaridade e idade, saúde, habitação e mobilidade.

Sobre os sonhos e perspectivas futuras, figura 110, o aluno sonha com uma faculdade pública na cidade de Ceilândia e que a humanidade tenha mais amor. $\mathrm{O}$ aluno pretende terminar seus estudos, cursar uma faculdade, conquistar um carro e possuir uma família ao lado de Deus. A sua base é alicerçada na família, nos amigos, no trabalho, em casa e em Deus. 


\begin{tabular}{|c|c|}
\hline \multirow[t]{3}{*}{ 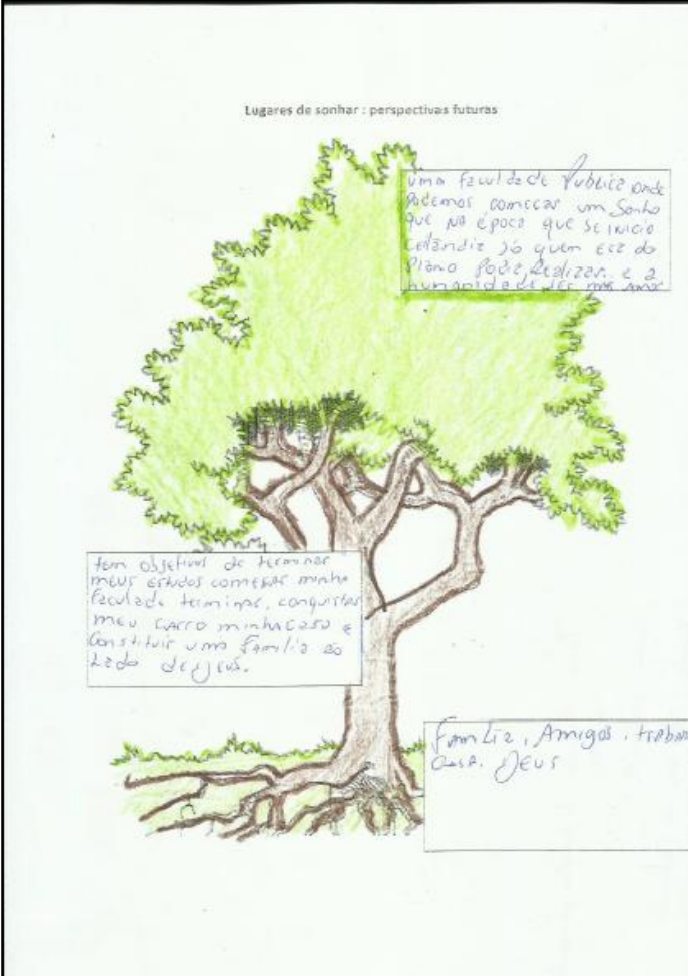 } & $\begin{array}{l}\text { Copa: Uma faculdade pública onde podemos } \\
\text { começar um sonho que na época que se } \\
\text { inicio Ceilândia só quem era do Plano Piloto } \\
\text { podia realizar. E a humanidade ter mais } \\
\text { amor. }\end{array}$ \\
\hline & $\begin{array}{l}\text { Tronco: Tenho objetivos de terminar meus } \\
\text { estudos começar minha faculdade terminar, } \\
\text { conquistar meu carro uma família ao lado de } \\
\text { Deus. }\end{array}$ \\
\hline & $\begin{array}{l}\text { Raiz: Família, Amigos, trabalho, casa. } \\
\text { Deus. }\end{array}$ \\
\hline $\begin{array}{l}\text { Figura 110. Lugares de sonhar: perspectivas futuras } \\
\text { aluno C-Oito. CEM } 03 \text { de Ceilândia-DF, } 2015 .\end{array}$ & \\
\hline
\end{tabular}

A partir da árvore do aluno é possível observar o discurso da sociedade como uma grande família constituída pela família, amigos tendo como centro Deus. Segundo Chauí (2000) a sociedade brasileira é marcada por seu aspecto conservador.

\begin{abstract}
Conservamos as marcas da sociedade colonial, escravista, ou aquilo que alguns estudiosos designam como "cultura senhorial", a sociedade brasileira é marcada pela estrutura hierárquica do espaço social que determina a forma de uma sociedade fortemente verticalizada em todos os seus aspectos: nela, as relações sociais e intersubjetivas são sempre realizadas como relação entre um superior, que manda, e um inferior, que obedece. As diferenças e assimetrias são sempre transformadas em desigualdades que reforçam a relação mando-obediência. O outro jamais é reconhecido como sujeito nem como sujeito de direitos, jamais é reconhecido como subjetividade nem como alteridade. As relações entre os que se julgam iguais são de "parentesco", isto é, de cumplicidade ou de compadrio; e entre os que são vistos como desiguais o relacionamento assume a forma de favor, da clientela, da tutela ou da cooptação. Enfim, quando a desigualdade é muito marcada, a relação social assume a forma nua de opressão física e/ou psíquica. A divisão social das classes é naturalizada por um conjunto de práticas que ocultam a determinação histórica ou material da exploração, da discriminação, e que, imaginariamente, estruturam a sociedade sob o signo da nação una e indivisa, sobreposta como um manto protetor que recobre as divisões reais que a constituem (CHAUÍ, 2000, p. 89-90).
\end{abstract}

Um dos fundamentos de uma sociedade conservadora é a manutenção de um sistema educacional discriminativo. Apesar do discurso da educação como instrumento de transformação social ela não é realizada como tal. 
Nas imagens enviadas pelo whatsApp são enfocadas várias brincadeiras infantis como bola de gude, pipa, jogar bola, figuras 111, 112, 113 e 114 .

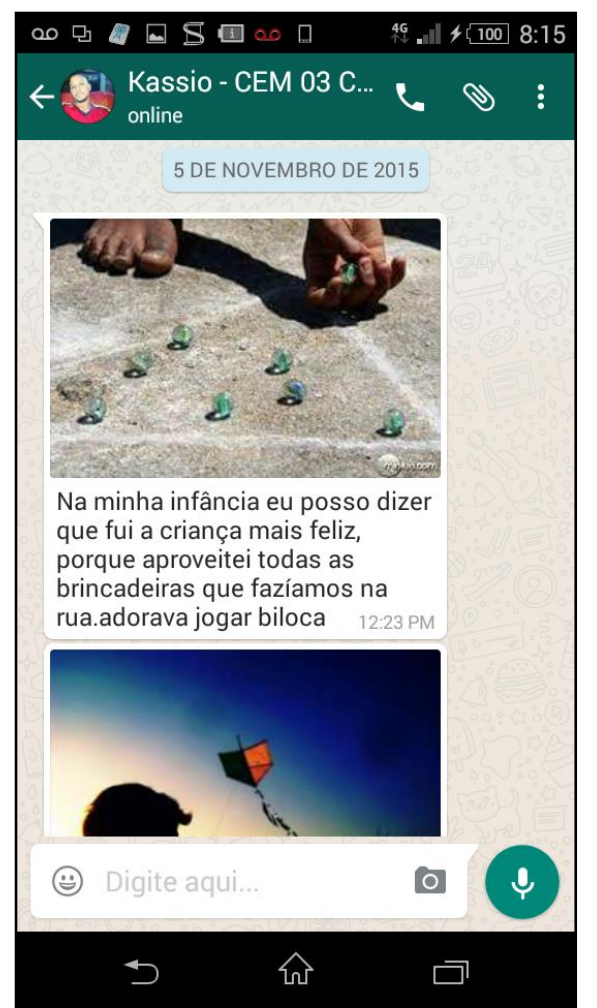

Figura 111. Mensagem do WhatsApp - aluno C-Oito. CEM 03 de Ceilândia-DF, 2015.
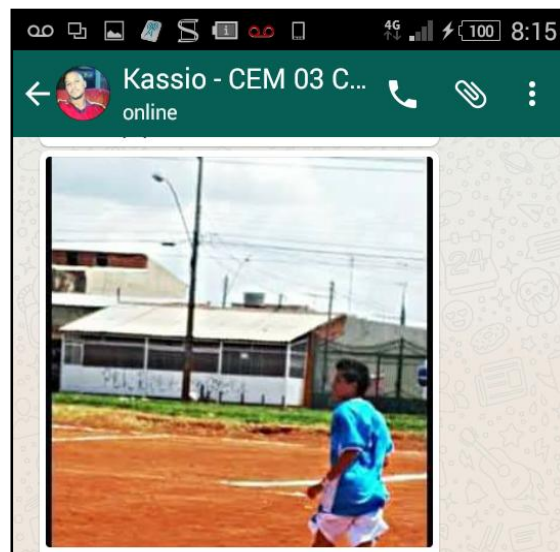

Eu sempre joguei bola desde piqueno.essa foto retra duas

épocas na Ceilândia.quando os

campos eram de barrão e hoje

com a modernidade o sintético

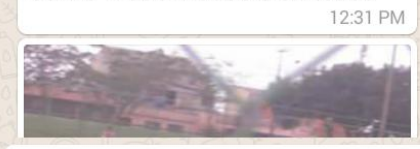

:) Pigite aqui...

이

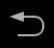

调

$\square$

Figura 113. Mensagem do WhatsApp - aluno C-Oito. CEM 03 de Ceilândia-DF, 2015.

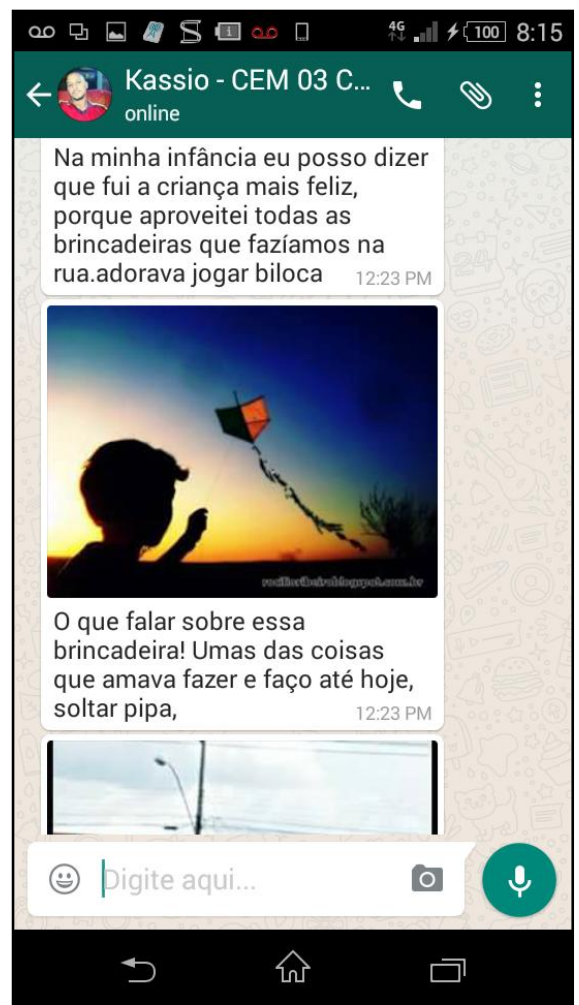

Figura 112. Mensagem do WhatsApp - aluno C-Oito. CEM 03 de Ceilândia-DF, 2015.

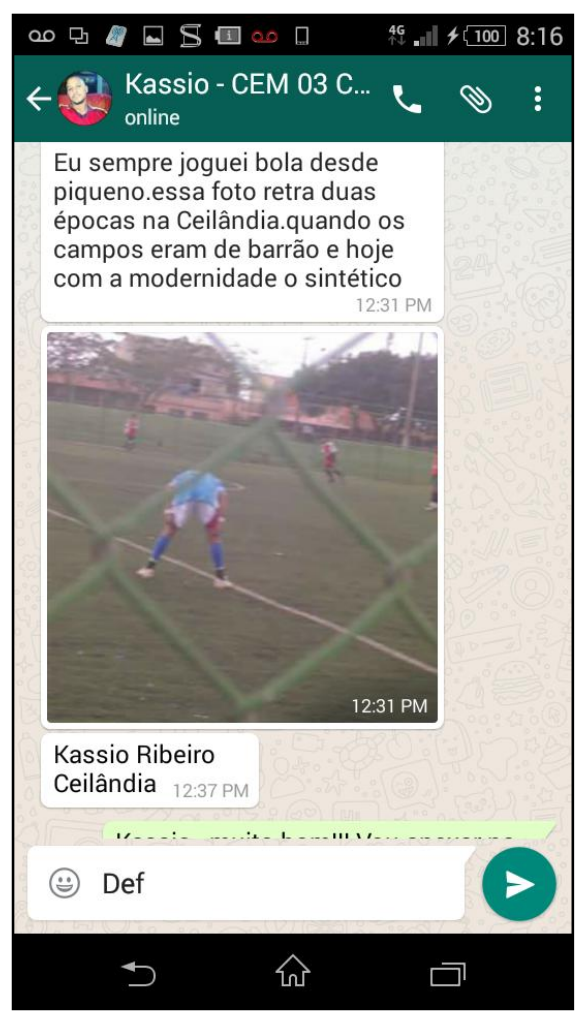

Figura 114. Mensagem do WhatsApp - aluno C-Oito. CEM 03 de Ceilândia-DF, 2015. 


\subsubsection{Narrativa Visual - Aluno C-Sete}

A narrativa visual do aluno é o desenho de uma bola de futebol, figura 115. Em sua geometria a bola de futebol sofreu transformação ao longo dos tempos. Atualmente, é um icosaedro truncado formado por 20 peças, denominadas de gomos e, geometricamente, de faces. As 12 faces são pentágonos regulares, e as outras, hexágonos, também regulares. Os lados dos pentágonos e dos hexágonos são iguais e costurados. Ao unirem-se os dos lados costurados das faces, forma-se as arestas. O encontro das arestas formam os vértices. Quando cheio, o poliedro é similar a uma esfera. O icosaedro truncado é um sólido de Arquimedes ${ }^{53}$, obtido por truncatura sobre os vértices do icosaedro.

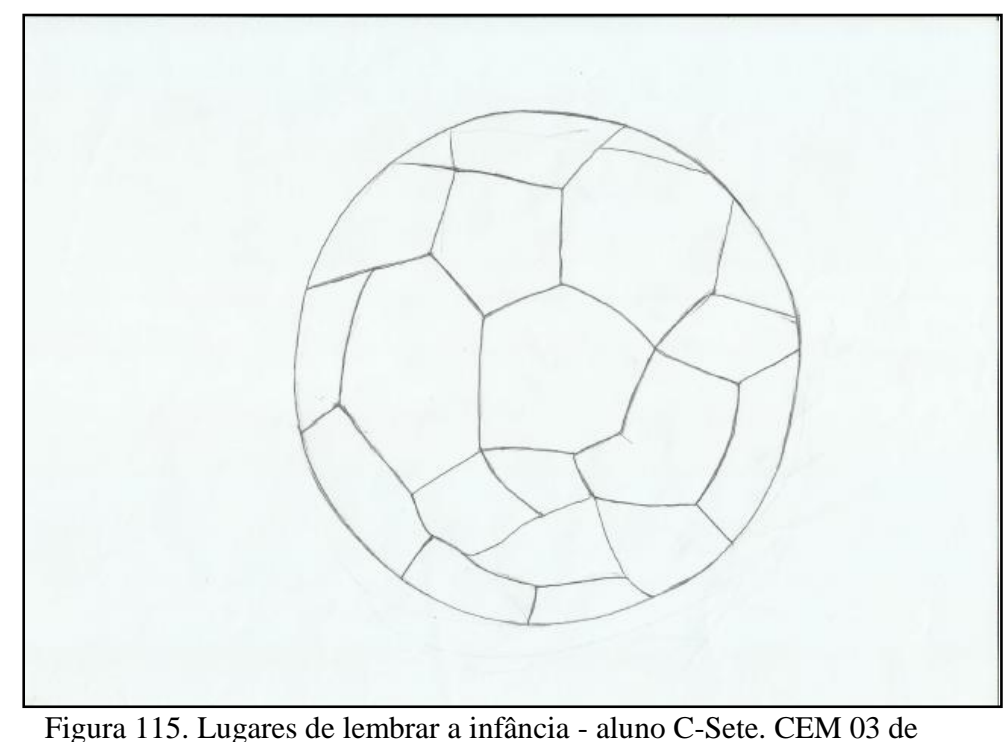

Figura 115. Lugares de lembrar a infância - aluno C-Sete. CEM 03 de Ceilândia-DF, 2015.

$\mathrm{Na}$ narrativa visual, lugares de lembrar a infância, o aluno simplesmente desenhou uma bola de futebol, o que lembra a poesia Jogo de Bola de Cecília Meireles:

$\begin{array}{cc}\text { A bela bola } & \text { A bola é mole, } \\ \text { rola: } & \text { é mole e rola. } \\ \text { a bela bola do Raul. } & \text { A bola é bela, } \\ \text { Bola amarela, } & \text { é bela e pula. } \\ \text { a da Arabela. } & \text { É bela, rola e pula, } \\ \text { A do Raul, azul. } & \text { é mole, amarela, azul. } \\ \text { Rola a amarela } & \text { A de Raul é de Arabela, } \\ \text { e pula a azul. } & \text { e a de Arabela é de Raul. }\end{array}$

\footnotetext{
${ }^{53}$ Arquimedes (287 a. C - 212 a.C) nascido em Siracusa é considerado um dos maiores matemáticos do mundo. Desenvolveu a Geometria da medida e o princípio físico que define a impulsão.
} 
Em sua narrativa sobre a cidade, figura 116, a primeira colagem é sobre uma comédia; a segunda, a imagem de uma mulher que parece ser uma chef de cozinha; em seguida, uma bola no ar prestes a ser captada pelas pernas do jogador. A quarta colagem apresenta uma pizza com vinho rose suave, e finalmente, um grupo de pagode.

O texto imagético parece remeter a uma cultura popular em oposição a uma cultura de elite. Entretanto, sabemos que atualmente o conceito de cultura tem um sentido dilatado, abrangendo tudo que pode se apreendido em uma sociedade, determinando o que se qualifica de cultura popular e cultura de elite que estão em permanente processo de ajustes, desajustes, reajustes, em constante movimento comunicacional com influências recíprocas, e inverte a maneira de interpretar as práticas culturais contemporâneas, recuperando as "astúcias anônimas" das artes de fazer, esta arte de viver a sociedade de consumo, como pensa Certeau (2002).

Isso reforça as ideias de Canclini (1998) de construção de uma cultura híbrida na América Latina, em que a modernidade é sinônimo de pluralidade mesclando relações entre hegemônicos e subalternos, tradicional e moderno, culto e simples, popular e massivo.

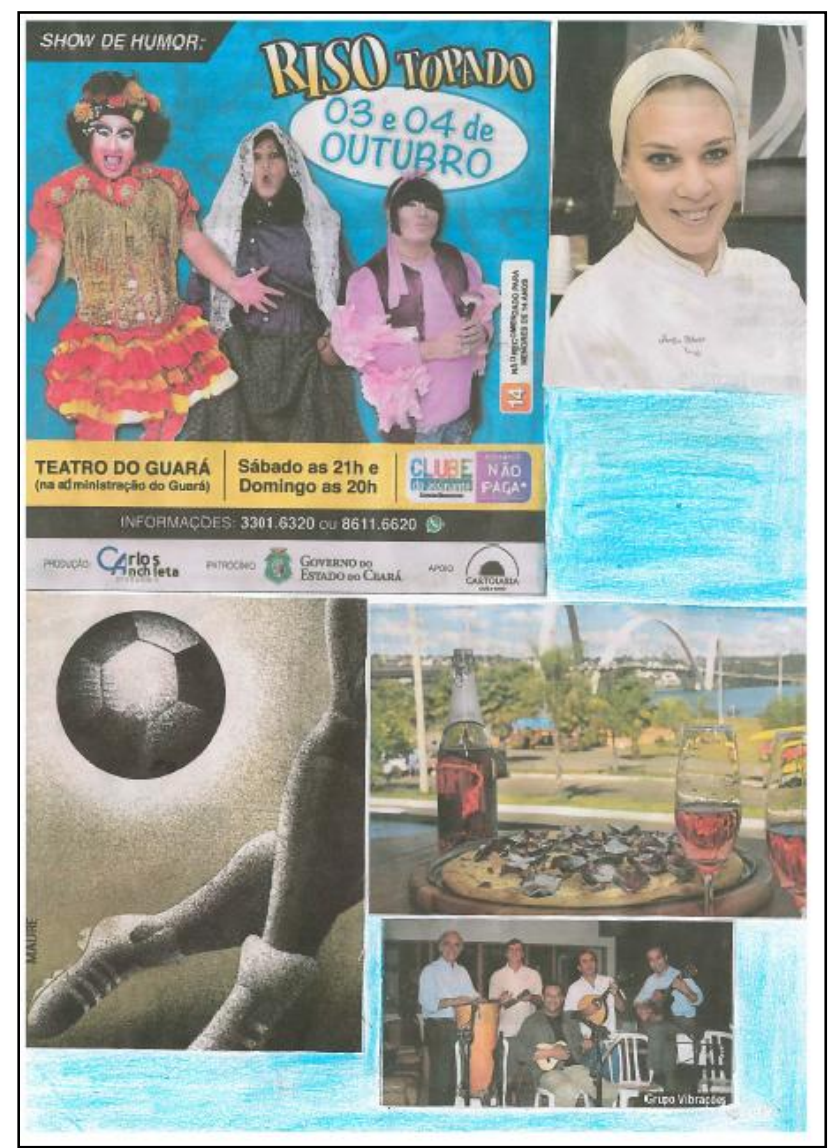

Figura 116. Lugares de lembrar a cidade e sua inserção - aluno C-Sete. CEM 03 de Ceilândia-DF, 2015. 
$\mathrm{Na}$ árvore que trata de sonhos e perspectivas, figura 117, a copa retrata as suas expectativas para o futuro. $\mathrm{O}$ aluno espera conseguir sua casa própria e ajudar a família a ter uma vida digna. Para o aluno conseguir seus objetivos precisa terminas os estudos, cursar uma faculdade, fazer uma especialização na área desejada. Seus projetos estão estruturados na fé em Deus, nos amigos e na perseverança.

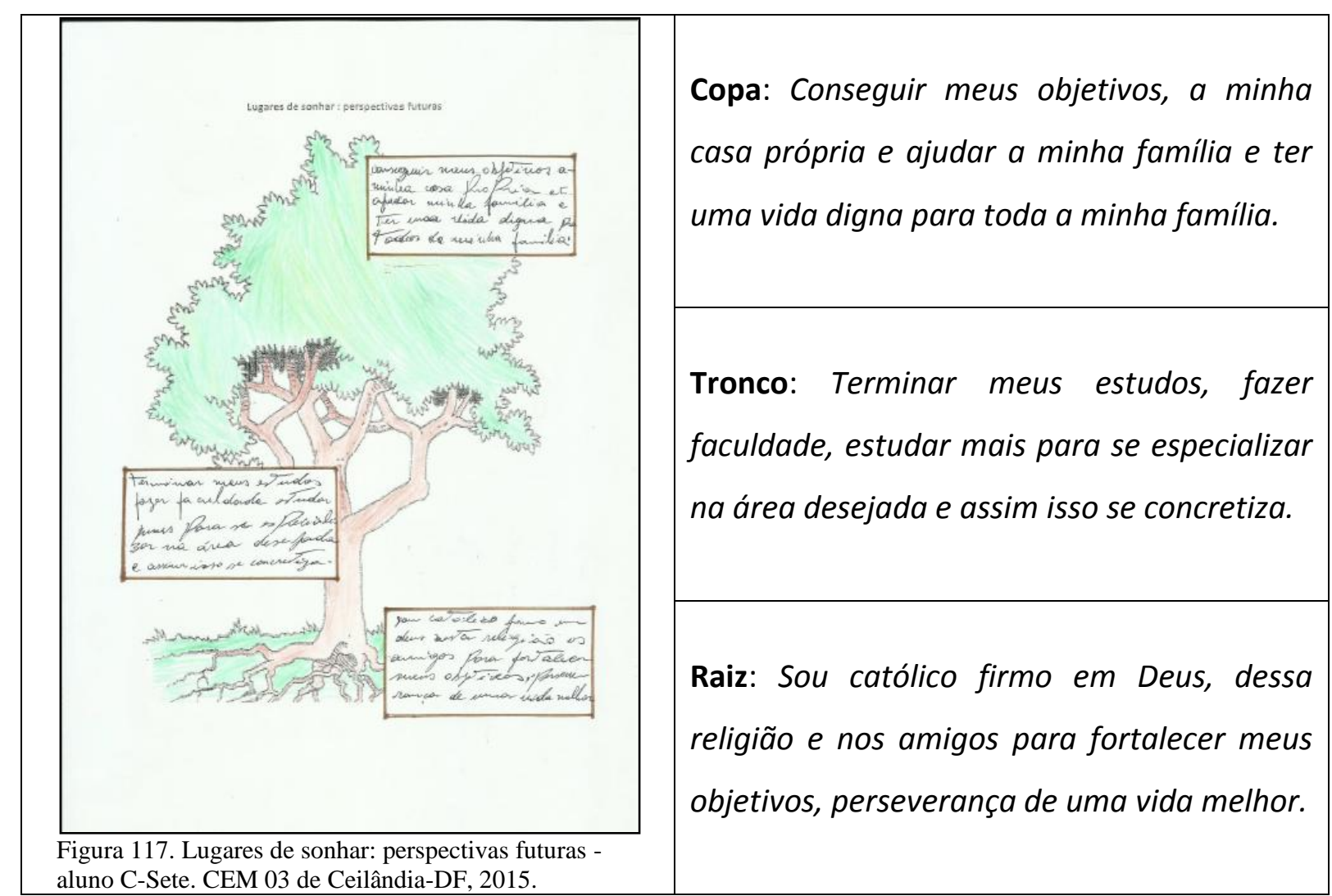

Como os demais alunos, C-Sete tem sonhos de construir um futuro melhor para ele e a família; tem como caminho para isso, o término dos estudos e assenta o seu futuro na família, nos amigos e na religião. Mostrando a importância atribuída pelo aluno à educação porque possibilita sair qualificado para o mercado de trabalho, comungando com os discursos oficiais de que é preciso estudar e trabalhar para subir na vida. Outro destaque é dado ao vínculo familiar, geralmente de uma família nuclear. Outro tópico é a religiosidade sempre relacionada a uma simbologia positiva de um futuro vindouro.

Para os autores Clandinin e Connelly (2011) a pesquisa narrativa é uma forma de compreender a experiência de ações corriqueiras, aquelas a que estão submetidas nossos fazeres e dizeres.

As narrativas são entendidas como um mecanismo de compreensão de si, dos outros e do mundo, revelando dimensões cognitivas, sensíveis e epistemológicas da experiência 
vivencial do sujeito, que ao contar e recontar essas histórias vai resignificando, tornando-as mais suas e ajudando-o a reelaborar seus desejos, sonhos e necessidades. Expondo os modos como o sujeito assimila, constrói e movimenta seus saberes, seus valores culturais, em permanente diálogo consigo mesmo e com os outros. Diálogos que vão contornando a subjetividade e a identidade cultural, embora sejam contornos provisórios que são modificados a cada experiência vivida, porque vivemos ali na experiência do outro, que se articula com a nossa experiência, como bem enfatiza Benjamin (1994, p. 201), "o narrador retira da experiência o que ele conta: sua própria experiência ou a relatada pelos outros. E incorpora as coisas narradas à experiência dos seus ouvintes".

Assim, a investigação apoiada na pesquisa narrativa, consiste em uma forma de dar voz aos sujeitos e a si própria, é também a maneira de criar novas histórias a partir daquelas que são circundadas, contadas e recontadas. Como entendida por Clandinin e Connelly (2011, p.26), "é um tipo de colaboração entre pesquisador e participantes, uma forma de viver e do contar, do reviver e recontar as histórias de experiências que compuseram as vidas das pessoas, em ambas perspectivas: individual e social".

\subsubsection{Narrativa Visual - Aluno C-Nove}

Olhando para a infância do C-Nove, o vejo jogando futebol com seus amigos, possivelmente significando momentos importantes que lhes proporcionavam aprendizagem prazerosa.

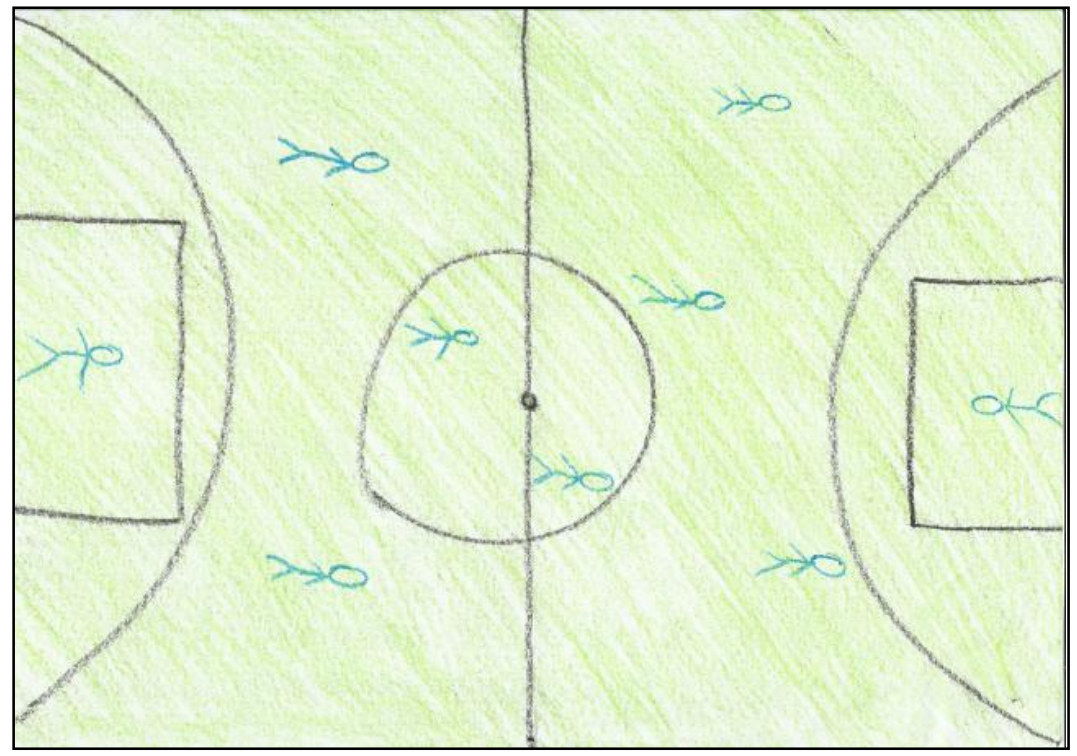

Figura 118. Lugares de lembrar a infância - aluno C-Nove. CEM 03 de CeilândiaDF, 2015. 
A sua narrativa, figura 118, apresenta um campo de futebol, pintado na cor verde e demarcado. De um lado, quatro jogadores e o goleiro e do outro, três jogadores e um goleiro. Demonstrando que além do futebol de várzea ${ }^{54}$ e a pelada ${ }^{55}$, a criatividade era tão grande que a falta de um local adequado, traves e marcações, bem como a limitação ou excesso de jogadores obrigava as crianças a criarem novos tipos de jogos de futebol.

Estudos sobre as práticas alternativas de futebol apontam que apesar da pouca atenção que costuma receber dos órgãos governamentais e das políticas públicas oficiais, elas se mantém vivas e podem ser caracterizadas como uma opção de lazer e sociabilidade que se contrapõem às práticas individualistas e segregacionistas que apontam para a desqualificação dos espaços públicos de sociabilidade. Segundo Damo (2003, p.150) "apesar de não ter o brilho e a sofisticação das últimas novidades da indústria do lazer, nem apresentar conotações políticas ou de classe explicitas, estão profundamente vinculadas ao modo de vida e às tradições das populações locais".

A rua como lugar de encontro, espaço da diversidade, da multiplicidade, do trânsito e das esquinas, mas também espaço do abandono, muitas vezes degradado e entregue ao descaso é o tema da narrativa do aluno C-Nove sobre a cidade.

A sua narrativa acerca da cidade, figura 119, um desenho com traços de caneta hidrocor e uma escrita como de pichações, de um parque destinado à prática do skate e do hip-hop. Uma demonstração de como a população se apropria dos espaços urbanos, fazendo surgir uma rede de produção cultural independente cuja novidade consiste na reprodução e divulgação de uma identidade local. Essas manifestações culturais urbanas, como o hip-hop, o grafite, a prática do skate, acontecem em locais públicos, como na rua ou em locais coletivos de acesso público, nascidos da apropriação por parte dos moradores dos espaços da cidade e começam a ter visibilidade e aceitação entre as demais manifestações urbanas centrais ${ }^{56}$.

\footnotetext{
${ }^{54}$ Futebol de Várzea é um termo usado principalmente na região sul e sudeste do Brasil que apresenta uma organização e um sistema de regramento próprio, apesar de, em muitos aspectos, está inspirando no futebol profissional. Ver http://lexsports.com.br/. Acesso em 02/07/2016.

${ }_{55}$ Pelada, racha, rachão ou baba é o nome dado no Brasil a uma partida recreativa de futebol com regras livres, normalmente sem a preocupação com tamanhos de quadra/campo, condição dos calçados e uniformes, marcações básicas, impedimentos, faltas, tempo de jogo. Muitas vezes as partidas são definidas em número de gols. Ver http://lexsports.com.br/. Acesso em 02/07/2016.

${ }_{56}^{5}$ Sobre a cultura marginal em Ceilândia ver o documentário do cineasta Adirley Queirós "Branco Sai, Preto Fica" (2014) que conta a história de dois homens que tiveram sua mobilidade reduzida após abordagens policiais truculentas no tradicional baile do Quarentão - festa black que acontecia no Centro de Ceilândia (DF) na década de 80 .
} 


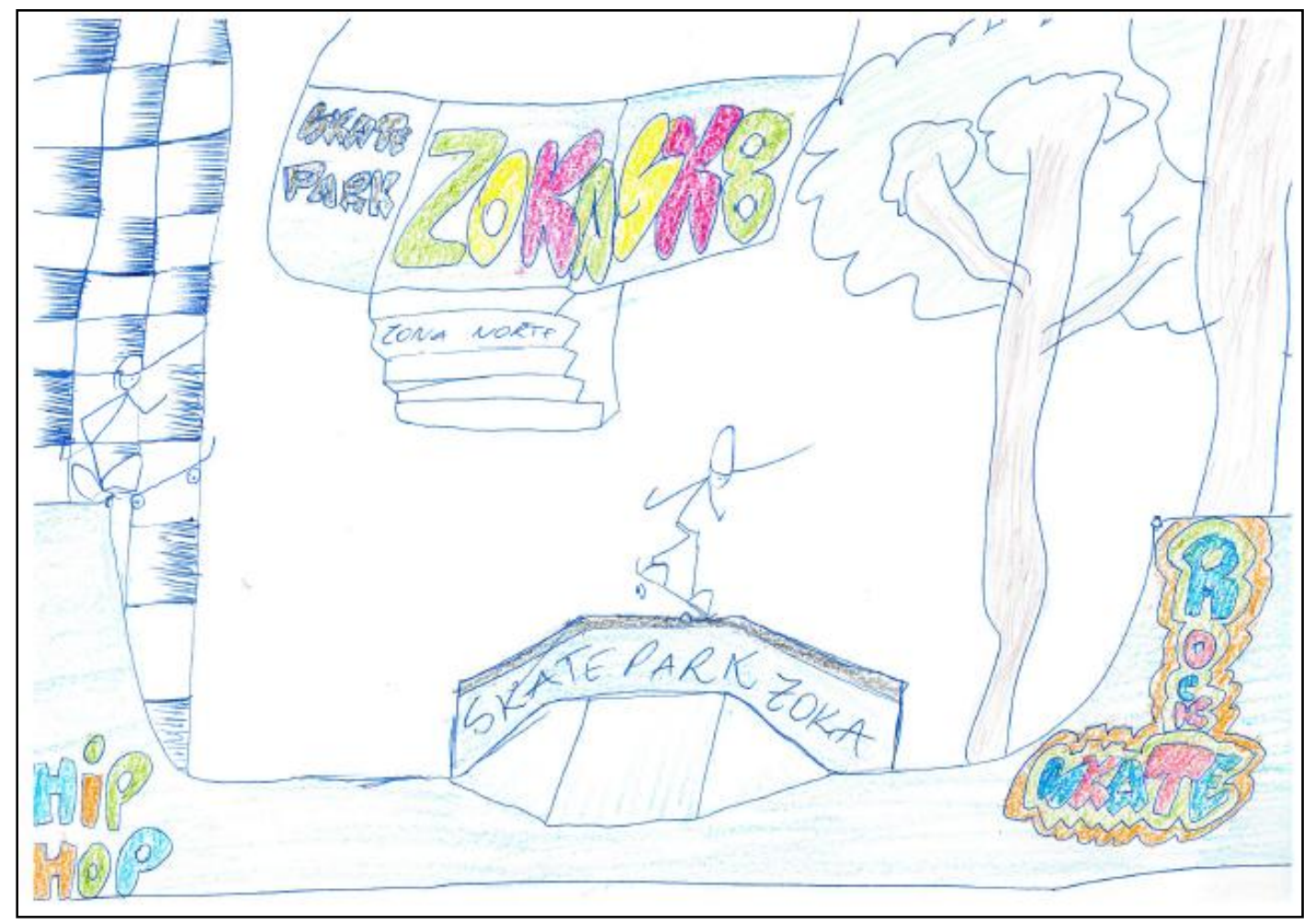

Figura 119. Lugares de lembrar a cidade e sua inserção - aluno C-Nove. CEM 03 de Ceilândia-DF, 2015.

Em seu estudo sobre a cultura marginal, Balbino (2006) afirma que essas manifestações se desenvolvem como resposta a uma condição de desigualdade social e passa a figurar como um importante elemento de mobilização das pessoas que partilham dessa cultura e também como ferramenta de comunicação com a sociedade: "a força que vem do lado negro, pobre e inferiorizado e atinge toda a sociedade com sua forma, sua arte e sua cor, forçando o debate de questões controversas de uma sociedade que se finge de surda para os gritos de protesto" (Balbino, 2006, p. 10).

Da mesma forma Victorio Filho (2014), ao analisar as culturas juvenis, afirma que o funk carioca é um modo de ser e estar no mundo, com seu vocabulário e outras estéticas corporificam uma forma de ver e criar o mundo. "Também é uma arma frente às violências simbólicas e adversidades materiais, assim como tem importância estratégica nos encontros que superam e ultrapassam as barreiras geradas pelas diferenças sociais, culturais e de outras ordens" (2014, p. 287).

$\mathrm{Na}$ verdade, o que o aluno evidencia é que a cidade fala: ela diz naquilo que acontece na rua. Ela possui uma língua, evidenciada nas suas particularidades próprias, expressas nas conversas, nos gestos, nas roupas, nas palavras e nas palavras de seus habitantes. 


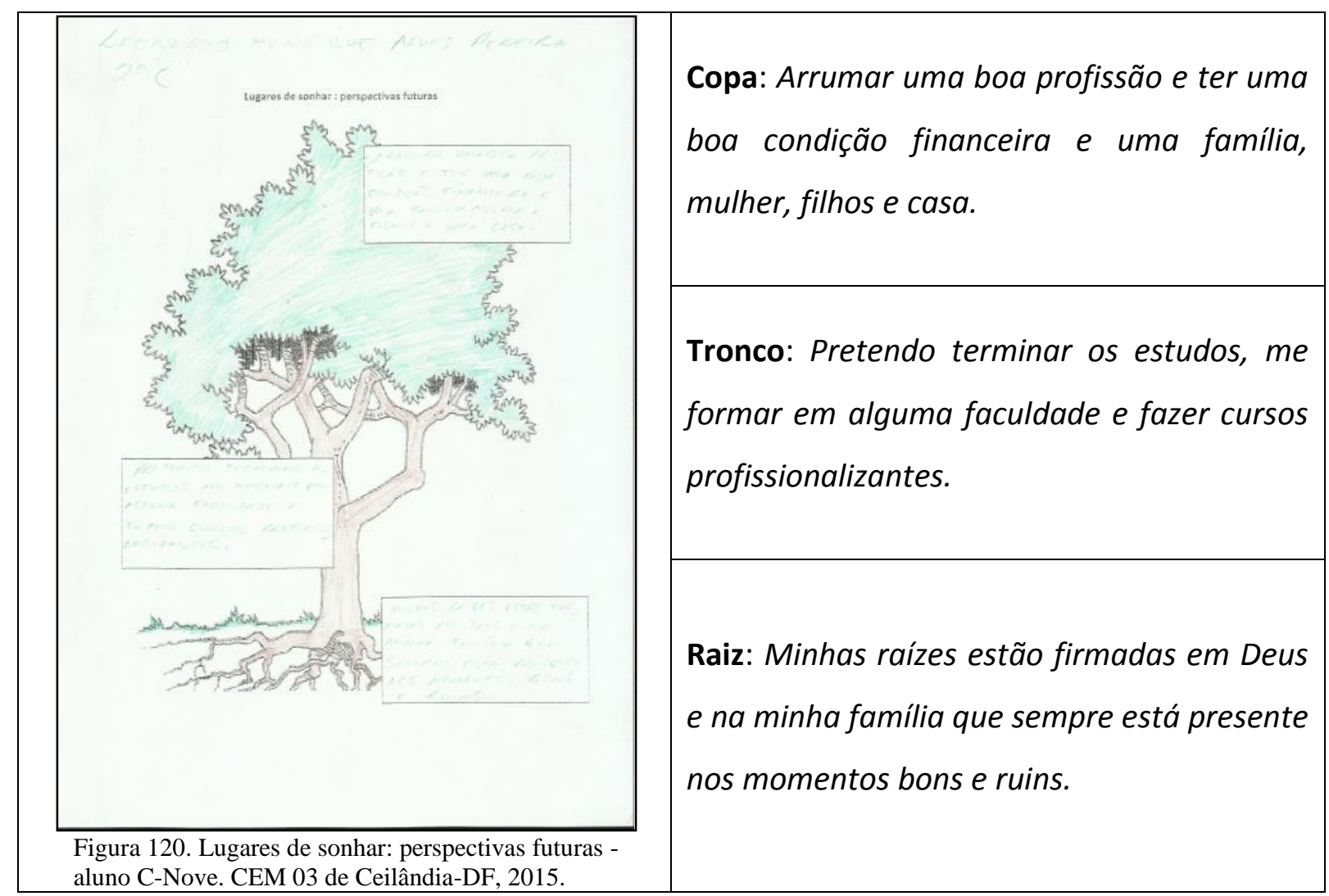

A sua árvore da vida, figura 120, não é diferente dos demais alunos: a perspectiva futura é arrumar uma boa profissão e ter uma boa condição financeira, uma família nuclear e uma casa. Para atingir seus objetivos pretende terminar os estudos, fazer uma graduação e alguns cursos profissionalizantes, apesar de não especificar em qual área. Seus projetos estão assentados em Deus e na família, presente nos momentos bons e ruins.

Estudos apontam que muitos dos alunos matriculados na educação básica (ensino fundamental e médio) abandonam a escola, entretanto, vários desses alunos retornaram ou retornarão à escola, mas em condições de defasagem idade/série, o que pode causar conflitos e possivelmente nova evasão Pacievitch (2010). Os motivos alegados por pais/responsáveis e pelos próprios alunos são a distância da escola até suas casas, o desinteresse, a dificuldade em se adquirir os conhecimentos básicos, a opção ou a necessidade de desenvolver uma atividade remunerada ou os atrasos em sua aprendizagem, segundo Cerrati (2008) e confirmados por Fortunato (2010): dificuldades de aprendizagem, esgotamento físico e falta de motivação para aprender. Uma vez que esses alunos retornam aos bancos escolares, reconhecem a necessidade da educação em suas vidas e buscam algo muito além de apenas abandonar o analfabetismo. Eles buscam por melhorar suas condições sociais, ingressar em um curso universitário e adquirir conhecimentos que os integrem a sociedade, como é possível perceber nas narrativas dos alunos da Ceilândia. 
A participação do aluno C-Nove no whatsApp ocorreu no dia 14/10/2015 com uma piada de bêbado, figura 121. O que nos remete ao documentário $O$ riso dos outros, (Brasil, 2012), dirigido por Pedro Arantes, mostrando que o humor, seja qual for o seu objeto, tem seu fundamento nos valores compartilhados socialmente, já que todo discurso tem raízes na sociedade, por isso, nem a piada nem o riso ocorrem no vácuo, seus alicerces são culturais, sociais, políticos e ideológicos. Quem conta a piada está consciente do que pronuncia e espera provocar o riso. Quem ri, o faz também, conscientemente, e ao fazê-lo reforça a mensagem. Não existe piada desprovida de conteúdo ideológico, político e social. Na verdade ela reforça preconceitos ou contribui para questioná-los. O que quer dizer que nem a fala nem o riso são naturais. O fundamento é social.

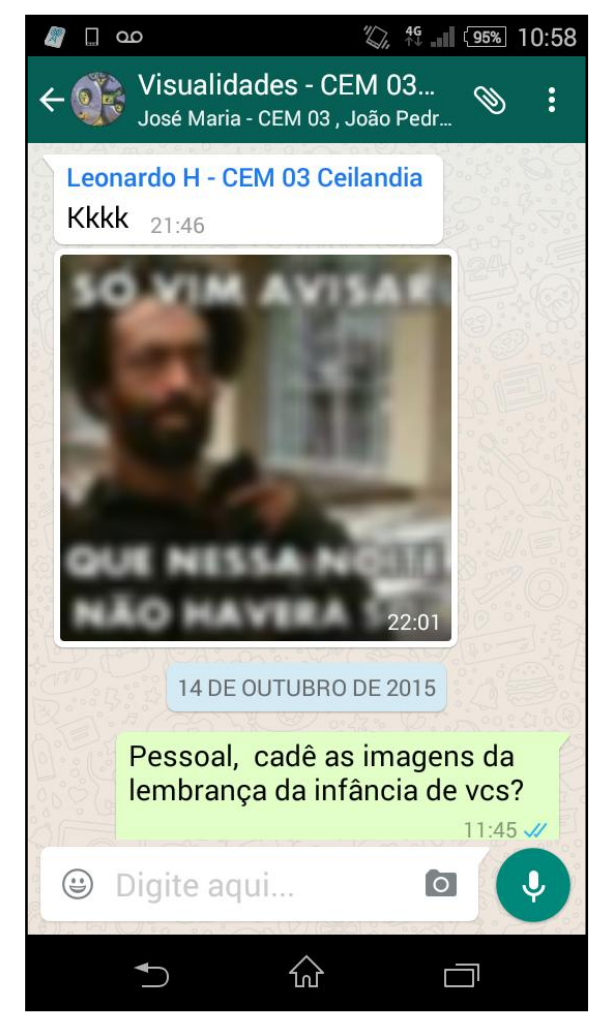

O aluno além da troca de mensagem sobre os conteúdo de aula questionava se haveria aula ou não, em função da greve parcial dos professores no CEM 03 de Ceilândia.

Figura 121. Mensagem do WhatsApp - aluno C-Nove. CEM 03 de Ceilândia-DF, 2015.

\subsubsection{Narrativa Visual - Aluna C-Três}

A narrativa visual da aluna C-Três, figura 122, referente à infância, apresenta uma boneca de cabelos pretos e laço vermelho, com um vestido rosa com uma flor azul na frente, em um fundo amarelo. A referência imagética de uma boneca e outras representações similares que permeiam a cultura infantil tornam-se as matrizes do feminino. Nesse sentido, a imagem da boneca fala às crianças sobre qual o modelo ideal do feminino preconizado por 
aquela sociedade. A associação das atividades lúdicas ao conceito de gênero é a trilha traçada por Carvalho (1990), que explora os significados das relações cotidianas estabelecidos na trama das relações sociais. $\mathrm{O}$ autor evidencia que a ideia de gênero (masculinidade/ feminilidade) são construtos sociais que passam pelas formas de lazer entre meninos e meninas. Assim, os jogos e os brinquedos ganham um sentido entre as crianças e constitui uma das primeiras formas que os meninos e as meninas aprendem, interpretam e internalizam as relações e gênero, já que nos brinquedos e jogos existe um código de significados compartilhado, não só entre os meninos e as meninas, mas também pelas pessoas que participam do aprendizado social, que determinam o que é permitido ou proibido e aqueles que são excluídos ou incluídos.

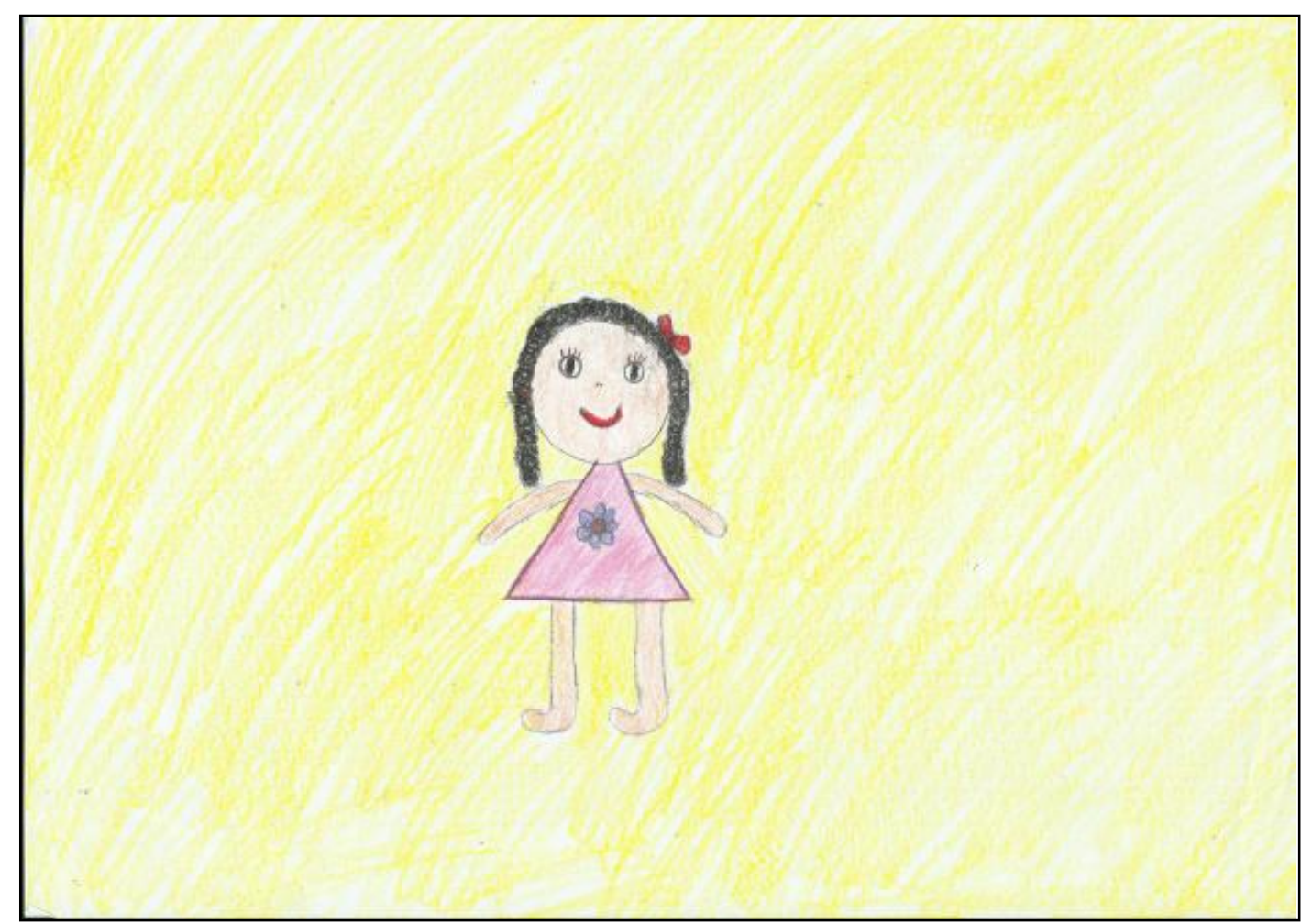

Figura 122. Lugares de lembrar a infância - aluna C-Três. CEM 03 de Ceilândia-DF, 2015.

A cultura visual nas tramas escolares: a produção da feminilidade nas salas de aula é o tema do estudo desenvolvido por Nunes (2010, p. 165). Nele a autora analisa a constituição de identidades femininas, por meio da cultura visual, concluindo que as inúmeras imagens, presentes em sala de aula, através dos brinquedos, livros com contos da literatura clássica infantil, materiais escolares e outros exercem pedagogias, pois produzem o imaginário de beleza física ideal e ensinam os comportamentos adequados para cada gênero. 
A narrativa sobre a cidade, figura 123 , a aluna C-Três elabora uma colagem sobre as manifestações culturais, que remete ao caráter híbrido da cidade cantada na MPB, representada na colagem de Maria Betânia (Abelha Rainha), Caetano e Gil. O ritmo regional do Estado do Pará é representado pela banda Calipso, em frequentes eventos festivos na cidade de Ceilândia.

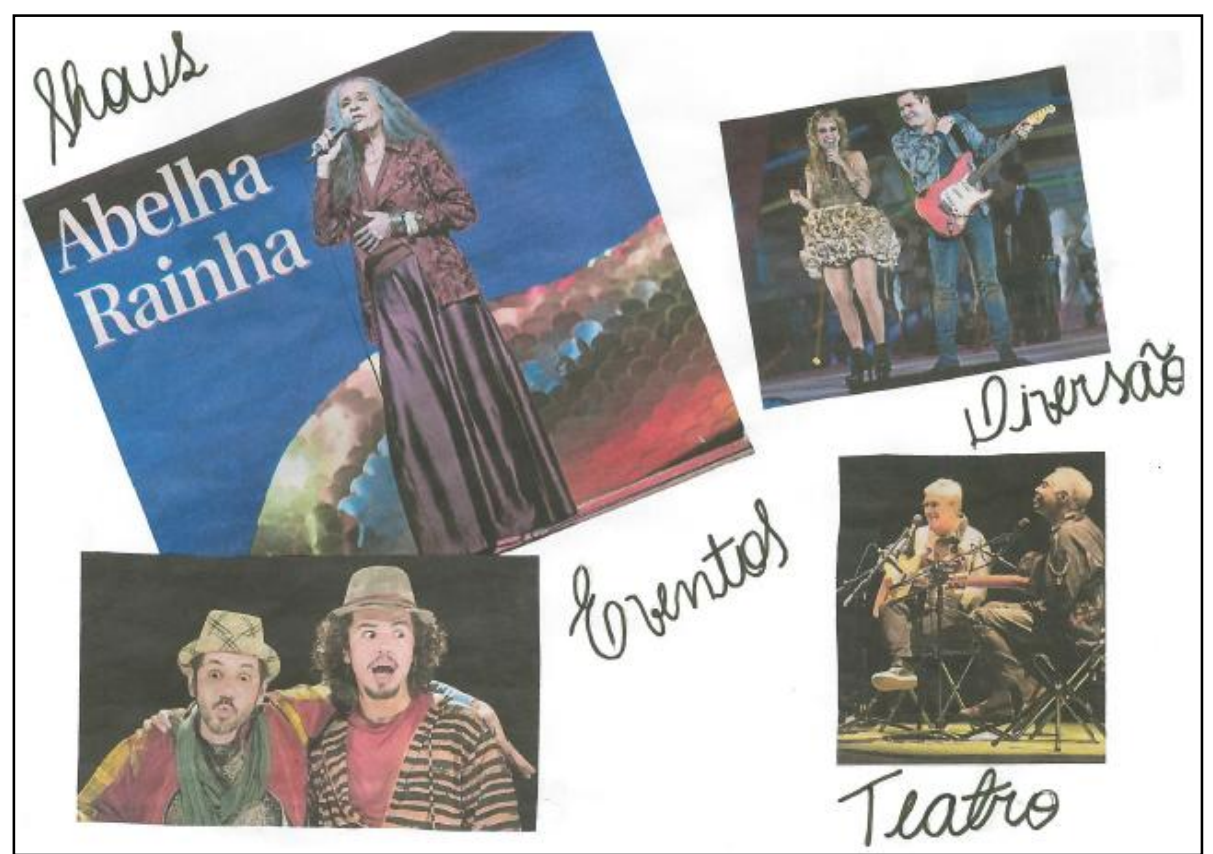

Figura 123. Lugares de lembrar a cidade e sua inserção - aluna C-Três. CEM 03 de CeilândiaDF, 2015.

Para as perspectivas futuras, figura 124, a meta da aluna é fazer um curso de bacharelado em medicina, casar, ter uma filha e trabalhar na área de saúde. Para atingir tais objetivos, a aluna quer continuar estudando e trabalhando em uma área que ela se identifica, morar sozinha e ser independente. Sustenta os seus projetos, a família, os amigos e a religião. 


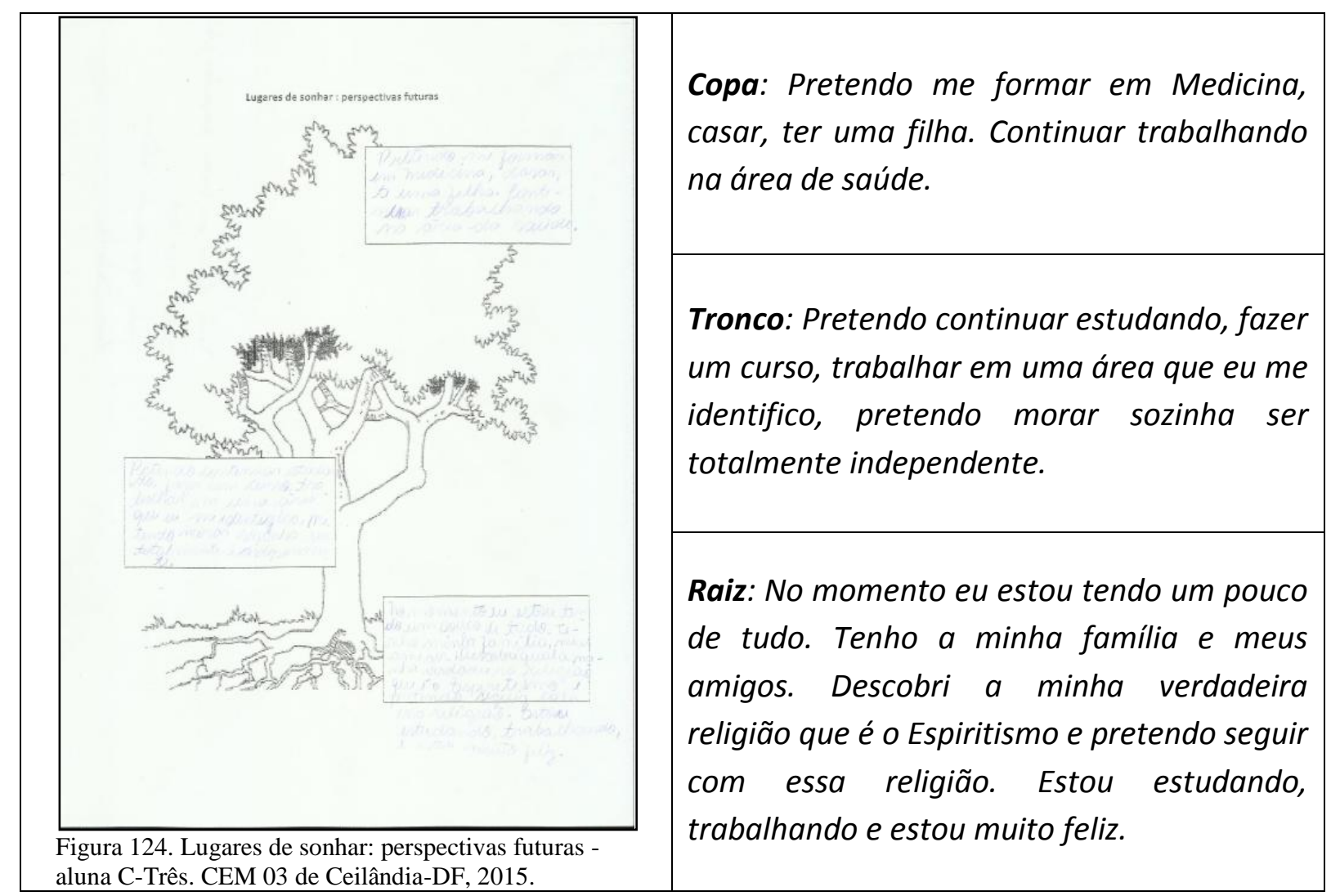

Sabemos que a opção pela carreira médica traz consigo mudanças fundamentais na vida do jovem ainda na adolescência. Ele enfrenta a intensa competição do vestibular, aprendendo precocemente a renunciar a desejos, prazeres, horas de lazer à companhia de amigos e familiares, preparando-se para a competição acirrada por uma vaga na universidade, principalmente nas públicas.

\subsubsection{Narrativa Visual - Aluna C-Doze}

A narrativa, figura 125, da aluna C-Doze é um desenho em lápis de uma boneca com um macacão roxo com bolinhas pretas. Entretanto, esta boneca não aparece com o mesmo ar de docilidade presente nas demais representações de bonecas. Ela é sorridente e tem um aspecto irreverente. A imagem sugere o distanciamento da representação feminina solidificada na imagem de passividade e submissão. 


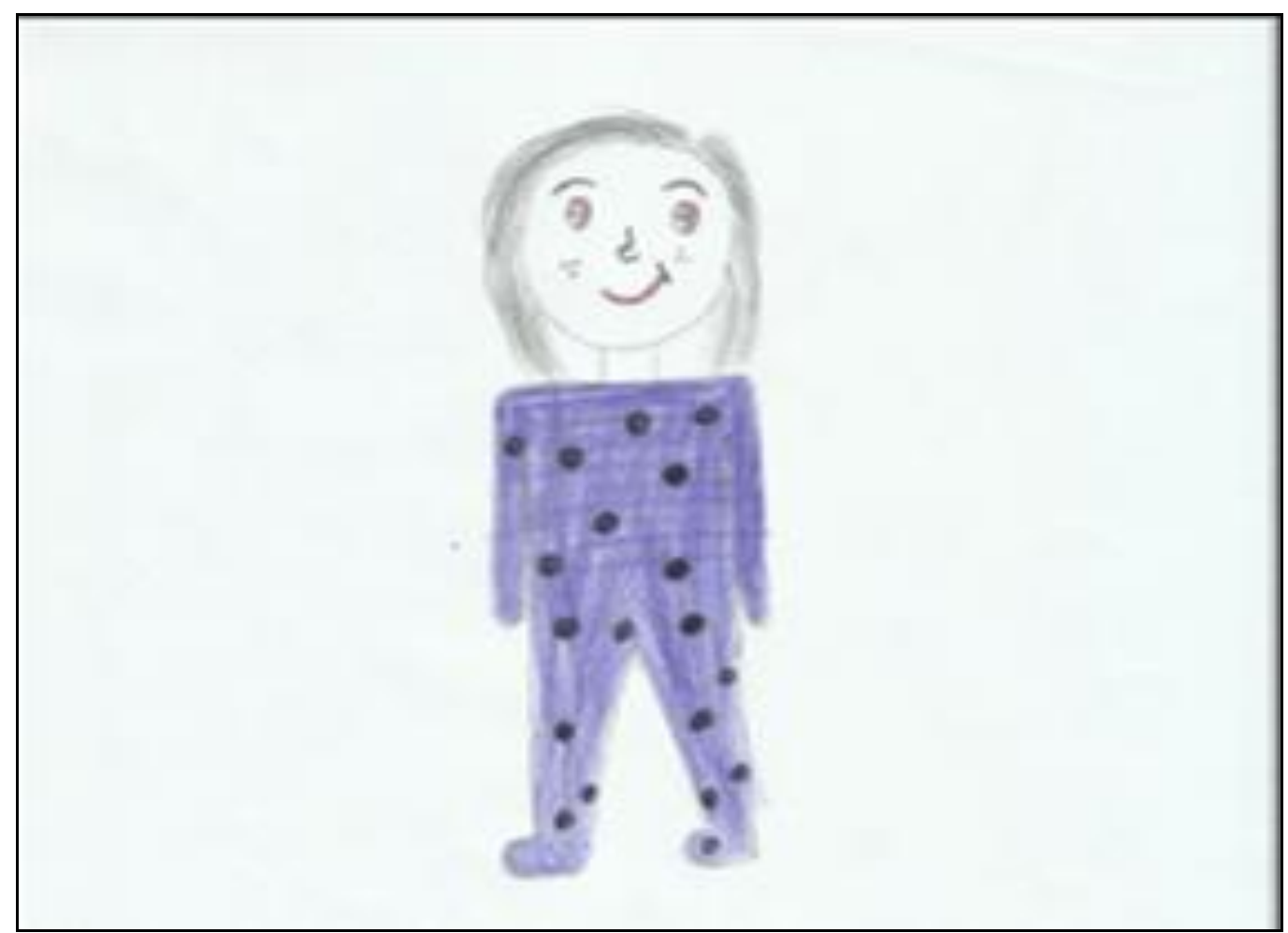

Figura 125. Lugares de lembrar a infância - aluna C-Doze. CEM 03 de Ceilândia-DF, 2015.

A narrativa sugere também, outro olhar, diferente daquele fabricado na cultura visual contemporânea em que os corpos femininos são idealizados e povoam as capas de revistas de moda e ditam as regras de um corpo perfeito. Corpos femininos idealizados que, por um lado, ensinam as mulheres como buscar o corpo perfeito de top model, enquanto nas revistas masculinas, os corpos perfeitos são oferecidos para o deleite visual dos homens. Estudo sobre o corpo feminino na mídia brasileira, desenvolvido por Louro (1999) indica que, principalmente em propagandas endereçadas ao público masculino como as campanhas de marcas de cervejas, celebram e naturalizam um corpo feminino sem voz, um corpo-objeto do olhar.

A narrativa da aluna acerca da cidade é uma colagem em um fundo vermelho composta por quatro figuras demonstrando algumas das atividades de lazer como teatro, cinema, shows e caminhada no calçadão, figura 126. 


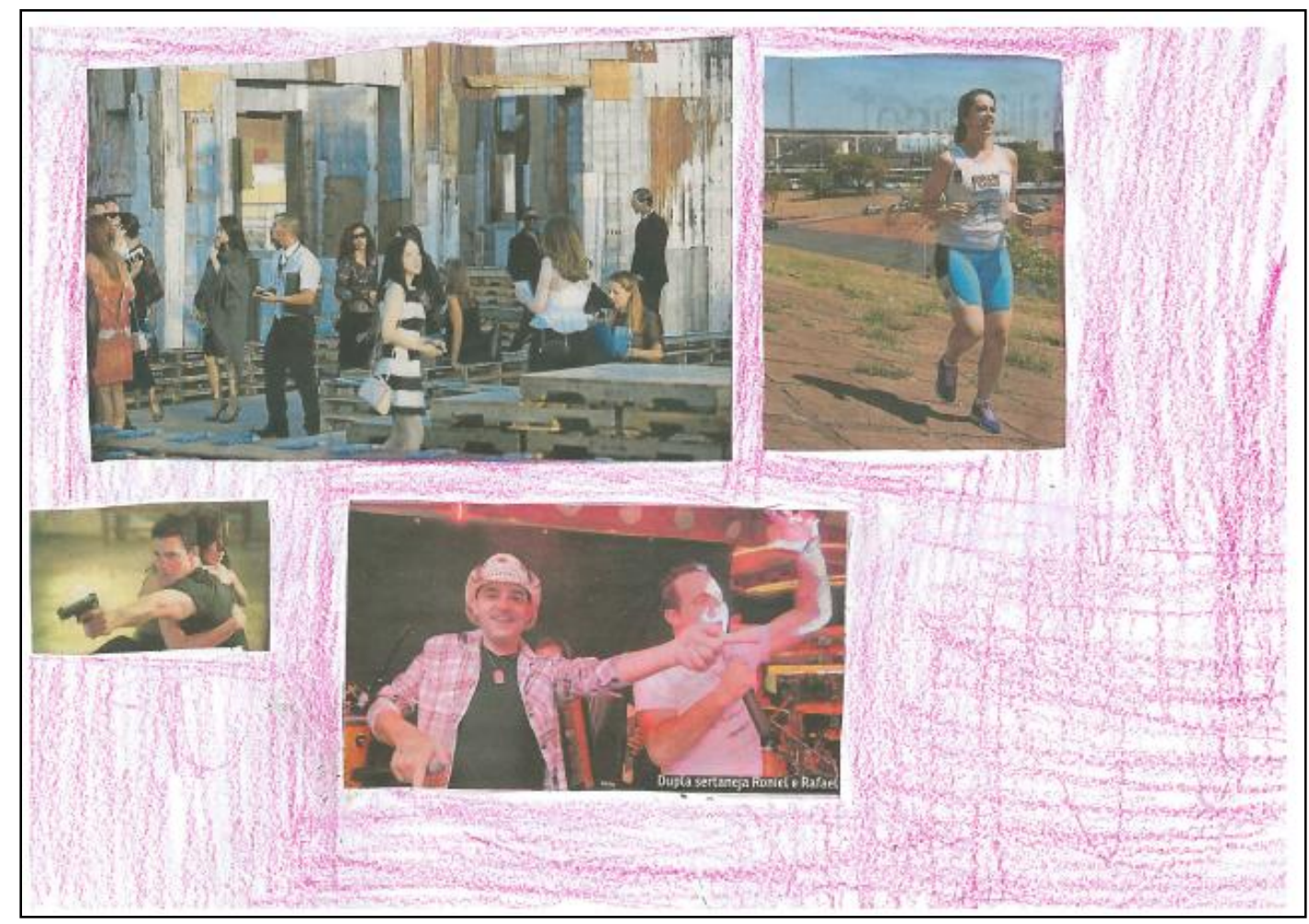

Figura 126. Lugares de lembrar a cidade e sua inserção - aluna C-Doze. CEM 03 de Ceilândia-DF, 2015.

Sobre os sonhos e perspectivas, figura 127, a aluna C-Doze pretende ter uma casa, um carro e um emprego e terminar os seus estudos. O seu tronco aparece vazio e o sustentáculo de seu projeto de vida se assenta na mudança na cidade de Ceilândia com a instalação de uma faculdade e a criação de mais empregos. 


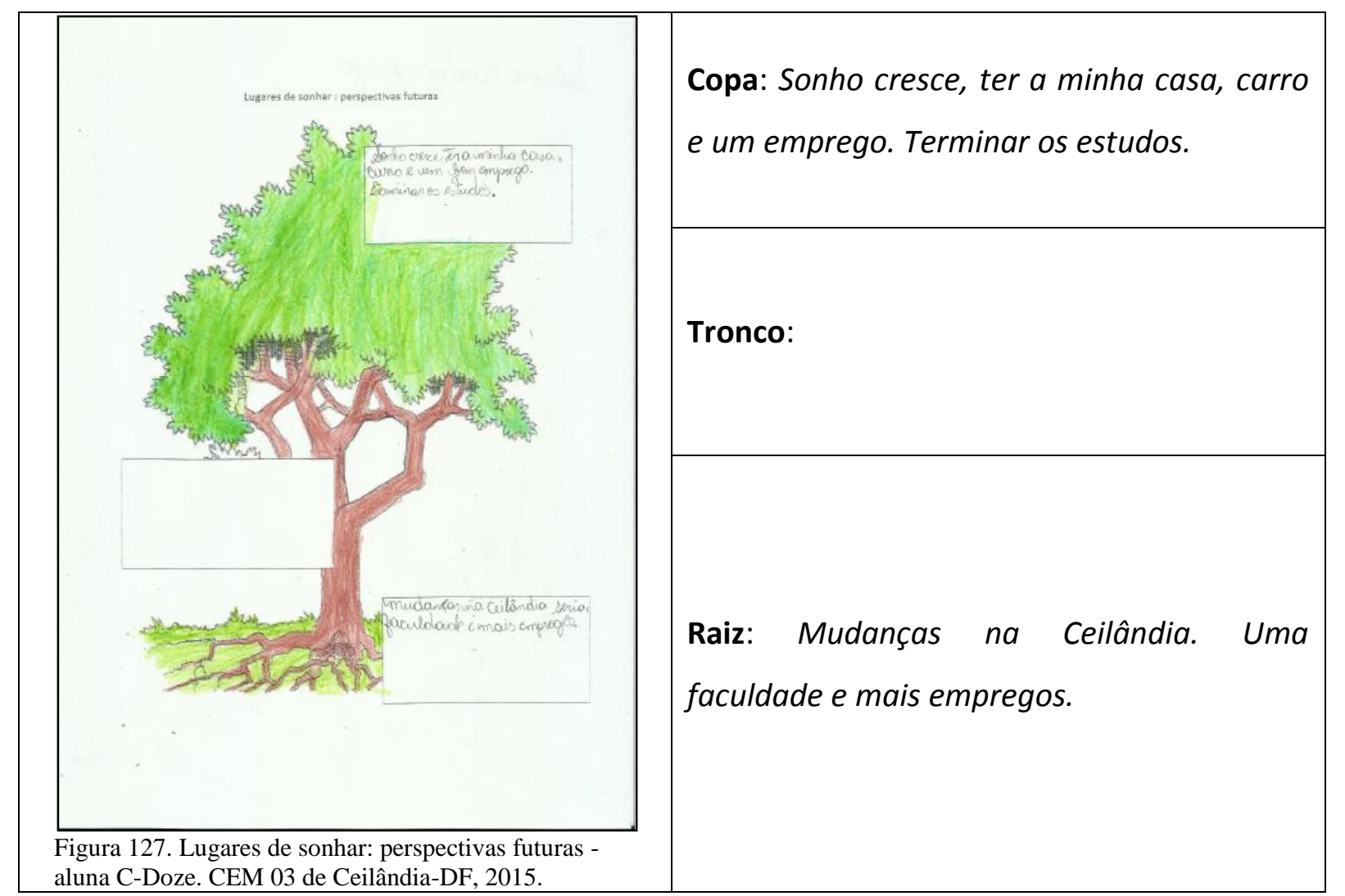

\subsubsection{Narrativa Visual - Aluno C-Cinco}

A narrativa visual do aluno C-Cinco é constituída por um desenho de uma casa, com portas e janelas abertas. A janela com cortinas amarelas que tremulam ao vento. Em sua Poética do espaço, Bachelard (1974) considera a casa "produto direto do coração da alma, do ser do homem tomado na sua atualidade". Na Infância, uma casa cercada por plantas ao lado de uma árvore plena de frutos é o indicativo de um espaço de proteção para a alma humana, e para o autor (1974, p. 358), a casa é nosso canto no mundo, nosso ponto de referência no mundo, como signo de habitação e proteção. Segundo Bachelard (1974, p. 359), a lembrança da primeira moradia nos acompanha durante toda a vida: "a casa abriga o devaneio, a casa protege o sonhador, a casa nos permite sonhar em paz". Nessa perspectiva, a casa tem o poder de interligar os pensamentos, lembranças, os sonhos do homem e os devaneios. Ela é o grande berço, o aconchego e proteção, desde o nascimento do homem ela está fisicamente inscrita em nós, ressoando ecos do passado. 


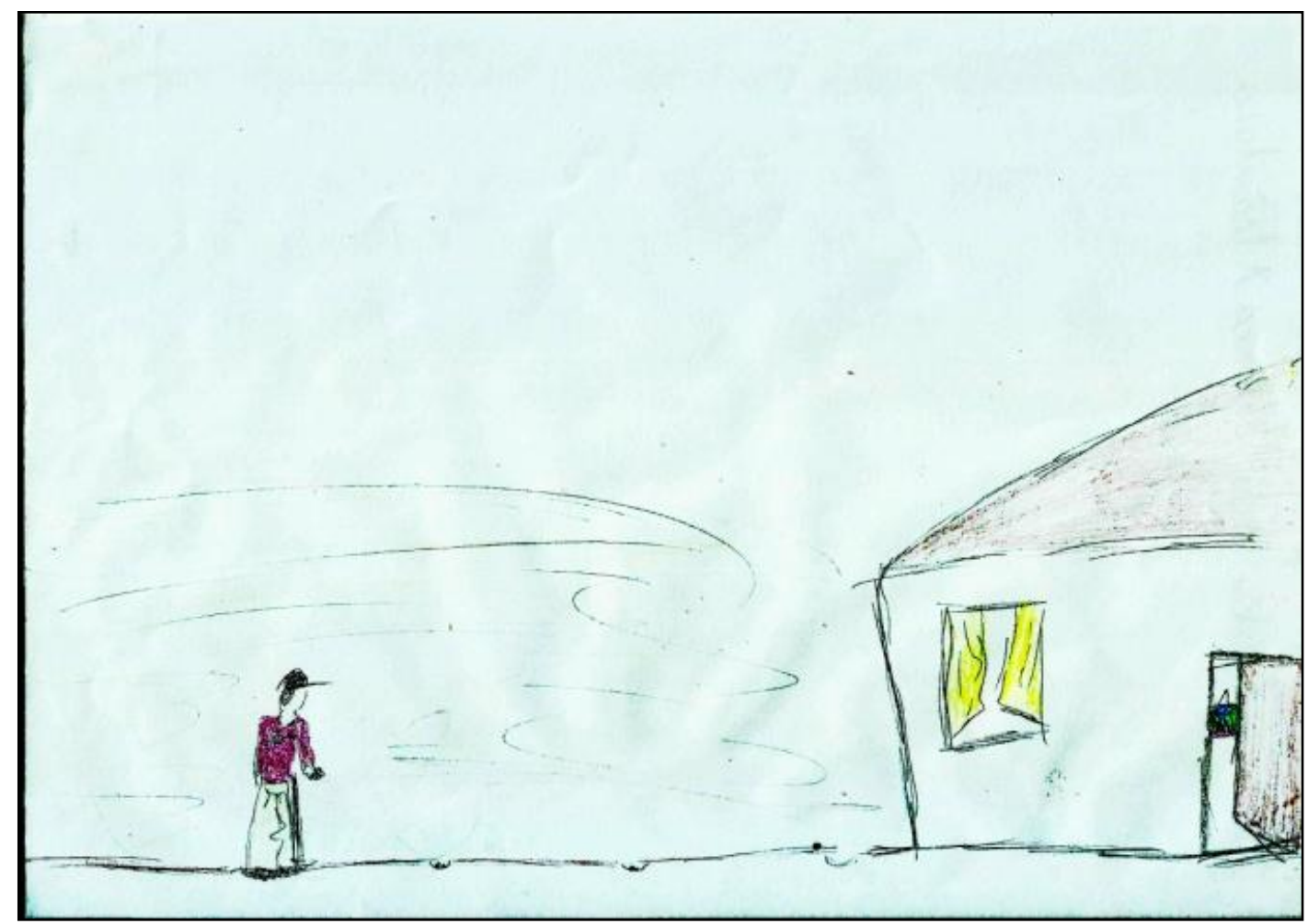

Figura 128. Lugares de lembrar a infância - aluno C-Cinco. CEM 03 de Ceilândia-DF, 2015.

Diante da casa uma criança brinca, figura 128, e está vestida com uma camisa vermelha, calça branca e boné. O movimento que a criança faz sugere que ela está jogando bolinhas de gude. O jogo de bolinhas de gude é o objeto do estudo de Carvalho (1990) que ao analisar o jogo praticado por meninos de uma cidade no interior de Minas Gerais, identifica uma série de aspectos que compõem a identidade masculina conforme é entendida na sociedade. Para Carvalho (1990), o jogo revela-se como uma forma de treinamento para as futuras atribuições masculinas na sociedade, como a manutenção da honra, a posse e administração do dinheiro. Para o autor, as situações propiciadas pelo jogo simulam, simbolicamente, desafios e dificuldades pelas quais um homem deve passar na sua vida cotidiana. Os desafios verbais entre os meninos, segundo o autor, é uma manifestação simbólica de aspectos da construção da identidade do gênero masculino. O autor identifica diferentes nomeações e regras do jogo de bolinha de gude, levando-nos a entender o papel ativo de crianças e adolescentes no processo de transmissão de cultura, o qual envolve a construção de significados veiculados pelos adultos e pelos grupos de pares. Segundo Pontes e Magalhães (2003, p. 117), enquanto os atores no processo de desenvolvimento brincam, mudam os significados que passam a ser compartilhados pelo grupo de brinquedos, ou seja, a transmissão cultural ocorre por meio da brincadeira de maneira bilateral. 
Sobre a narrativa da cidade, o aluno C-Cinco, figura 129, afirma que "em dias atuais nossa cidade perde muito em termos de parque e natureza”. Fato enfocado anteriormente, que sugere a segregação social e espacial gerada pelas áreas verdes. Os espaços com áreas verdes são acessíveis para os estratos sociais que podem adquirir imóveis residenciais nos condomínios fechados; enquanto os espaços públicos, como os parques e outras áreas verdes, que são patrimônios naturais de um determinado bioma ou lugar são cada vez mais afetados pela especulação imobiliária e pela falta de interesse do bem coletivo.

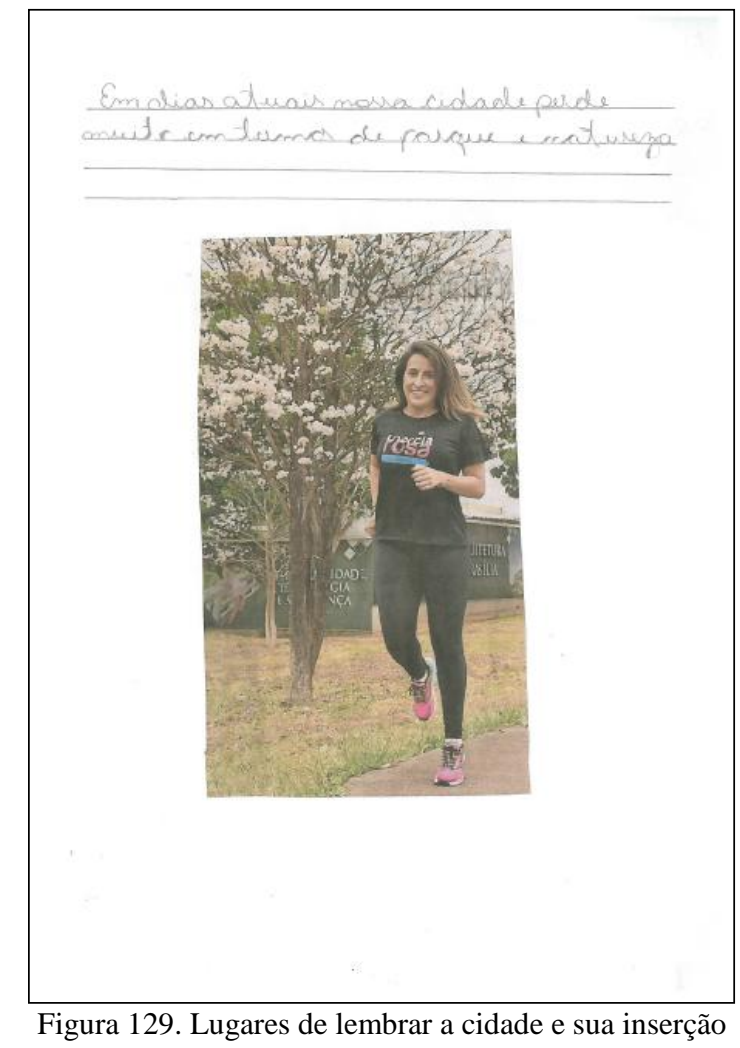

Em dias atuais

nossa cidade perde

muito em termos de

parque e natureza. - aluno C-Cinco. CEM 03 de Ceilândia-DF, 2015.

Na sua árvore de sonhos e projetos, figura 130, o aluno C-Cinco deseja que a cidade tenha uma faculdade, pretende terminar o ensino médio, sendo seus planos assentados na família, amigos e em Deus. 


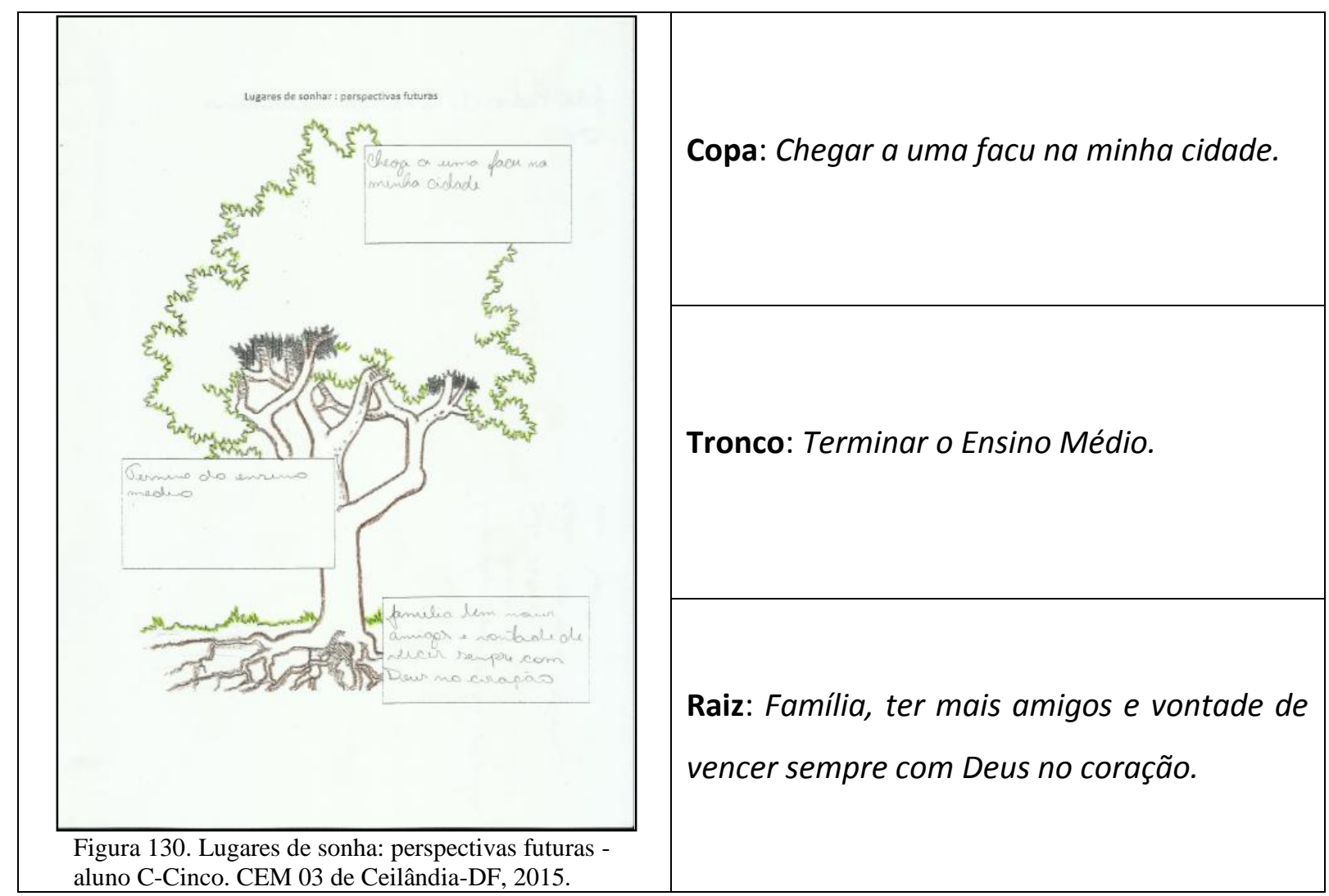

\subsubsection{Narrativa Visual - Aluno C-Seis}

A narrativa do aluno C-Seis, figura 131, apresenta o desenho de um jogo de damas, traçado em branco e preto com marcadores de um lado verde e de outro vermelho. O jogo de damas requer do jogador o domínio de três elementos básicos: a teoria, o raciocínio e a astúcia, considerados características masculinas de sobrepor-se ao outro em uma disputa.

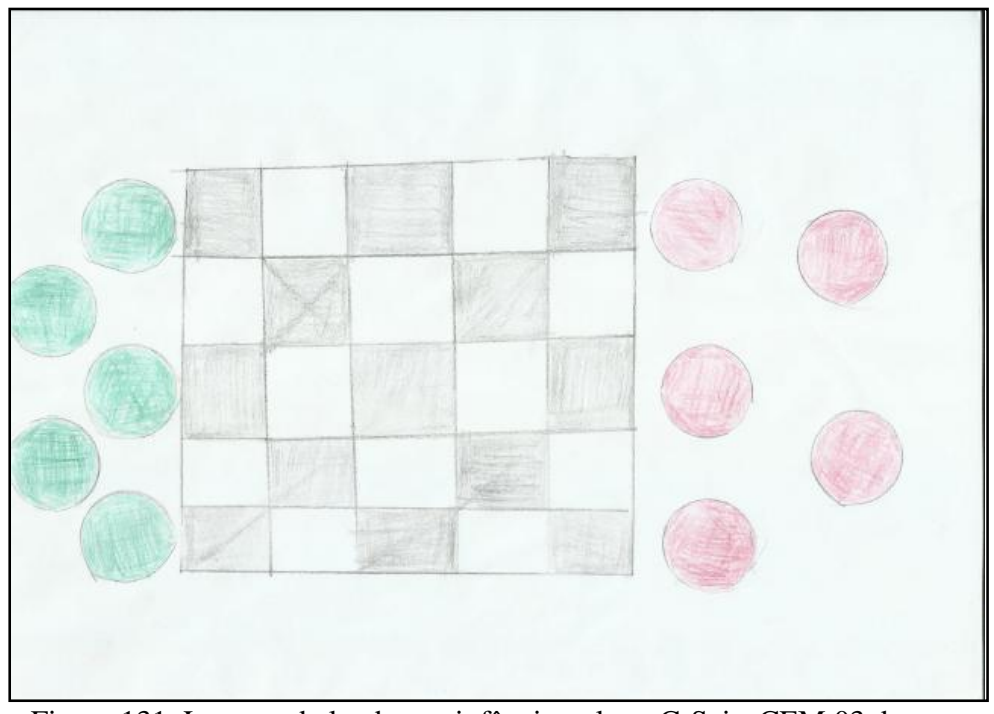

Figura 131. Lugares de lembrar a infância - aluno C-Seis. CEM 03 de Ceilândia-DF, 2015. 
A análise das representações de gênero e sexualidade na visualidade contemporânea e suas implicações na educação foi tema do estudo desenvolvido por Dias (2011), no qual evidencia a permanência da legitimação do discurso heterossexual, apresentado como natural que justifica a censura às representações transgênicas e homossexuais, consideradas artificiais. Como observam Irene Tourinho e Raimundo Martins, na apresentação do livro o I/Mundo da Educação em Cultura Visual "investiga e transgride os sentidos com os quais percebemos a cultura, a educação e, especialmente, a arte-educação" (Dias, 2011, p. 17).

A narrativa do aluno C-Seis acerca da cidade, figura 132, é o desenho de um celular com traços em vermelho e a logomarca da empresa, fones de ouvidos para a escuta de músicas e a presença de três estrelas de seis pontas. A produção do material visual narra muitas histórias, uma das possibilidades é o caminho aberto por Gonçalves (2011) no qual os modernos aparelhos que reproduzem músicas gravadas alteraram o modo como o homem se apresenta, interage e percebe o mundo. $\mathrm{O}$ desenvolvimento das técnicas de registro e reprodução sonora fez com que os indivíduos se identificassem com uma música gravada e reproduzida em larga escala e possibilitou a criação de laços simbólicos e afetivos com uma canção apropriada e consumida por vários outros sujeitos.

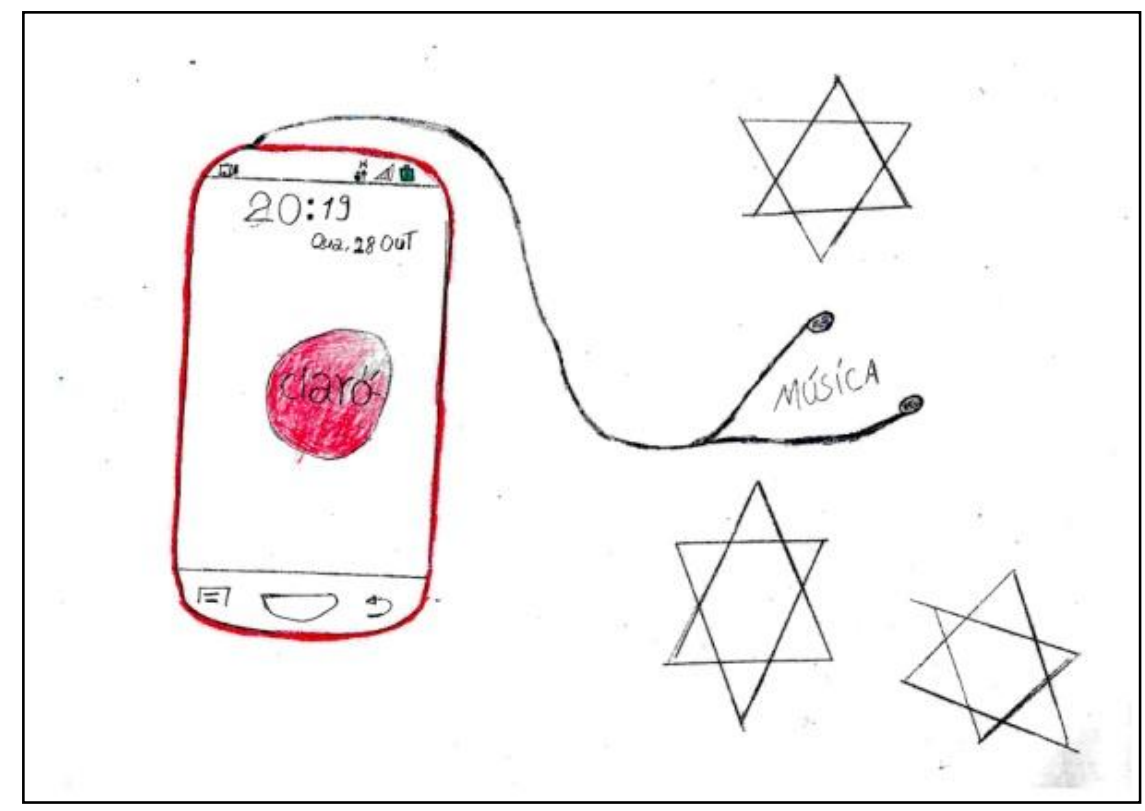

Figura 132. Lugares de lembrar a cidade e sua inserção - aluno C-Seis. CEM 03 de Ceilândia-DF, 2015.

Outro caminho é proposto pela pesquisa realizada por Oliveira (2012) onde investigou as contribuições e influências da música no processo de construção da identidade na juventude. A pesquisa foi realizada com jovens moradores da região metropolitana de Belo 
Horizonte/ MG, que afirmam que com a música eles estabelecem trocas, experimentam, se relacionam, divertem-se, produzem, sonham, constroem e falam de suas identidades pessoais e dos diferentes modos de ser jovem.

Na sua conclusão, Oliveira (2012) observa que a música além de ser um instrumento de aquisição de cultura e de lazer, pode servir como uma ferramenta de integração social, apresentando-se como um modo de demarcar/refletir diferenças psicológicas e socioculturais, ajudando a criar concepções, rótulos, grupos de convivência e até mesmo estigmas.

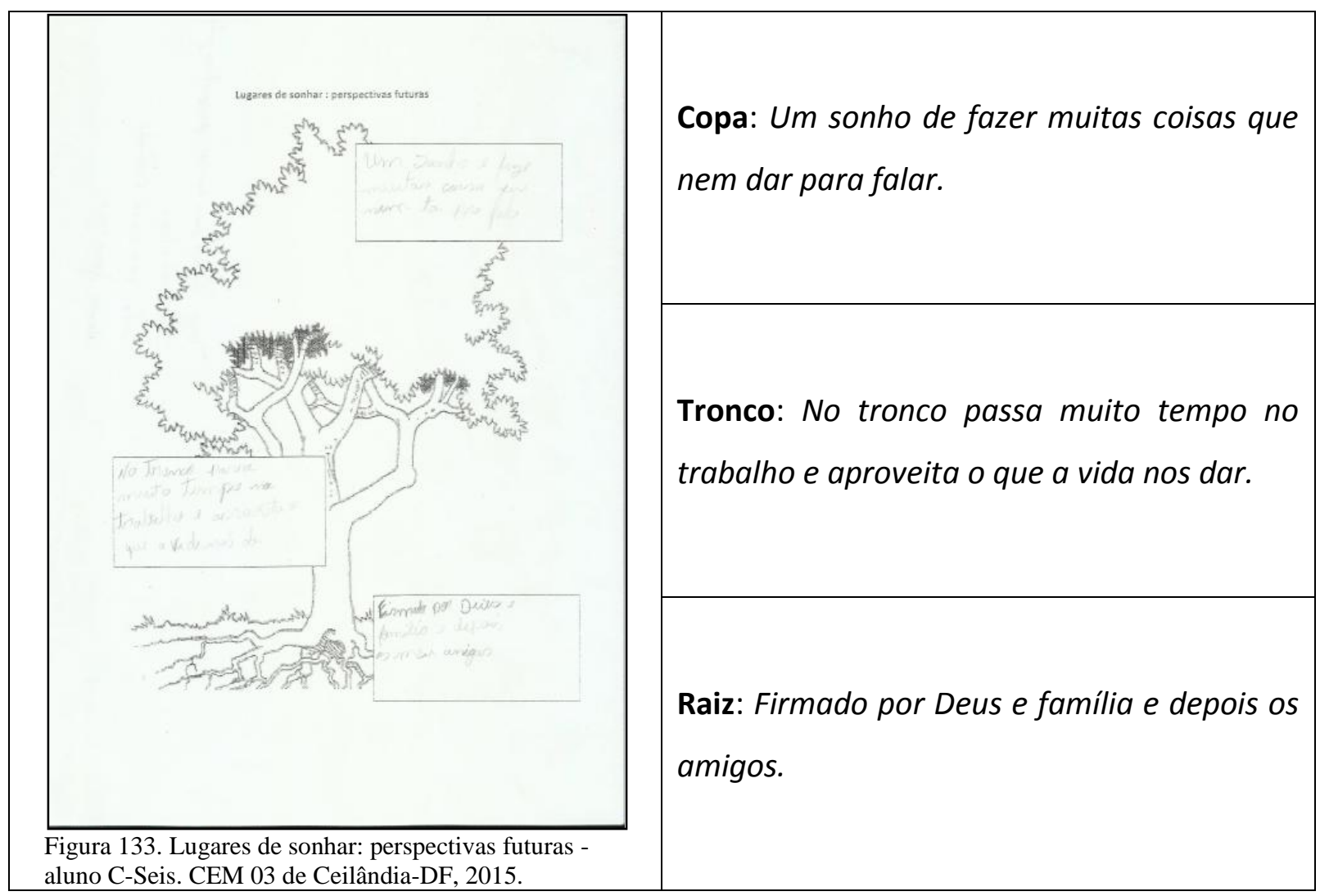

Os projetos futuros, figura 133, não são especificados pelo aluno, afirma que deseja tanta coisa que não consegue falar, pretende trabalhar bastante e aproveitar o melhor da vida. Seus projetos estão firmados em Deus, na família e nos amigos.

As mensagens enviadas pelo whatsApp misturam piadas com louvor religioso, figuras 134, 135 e 136. Uma das piadas é sobre sogras. Possenti (1998) ao analisar a discursividade das piadas de sogras, identifica os sentidos negativos que os genros demonstram. De uma forma geral, o riso acontece com a quebra dos sentidos negativos atribuídos pelo sujeito genro. A mesma quebra de sentido que provoca o riso pode ser encontrado na piada do ladrão, que veicula uma visão sintetizada do problema (falta de dinheiro). 


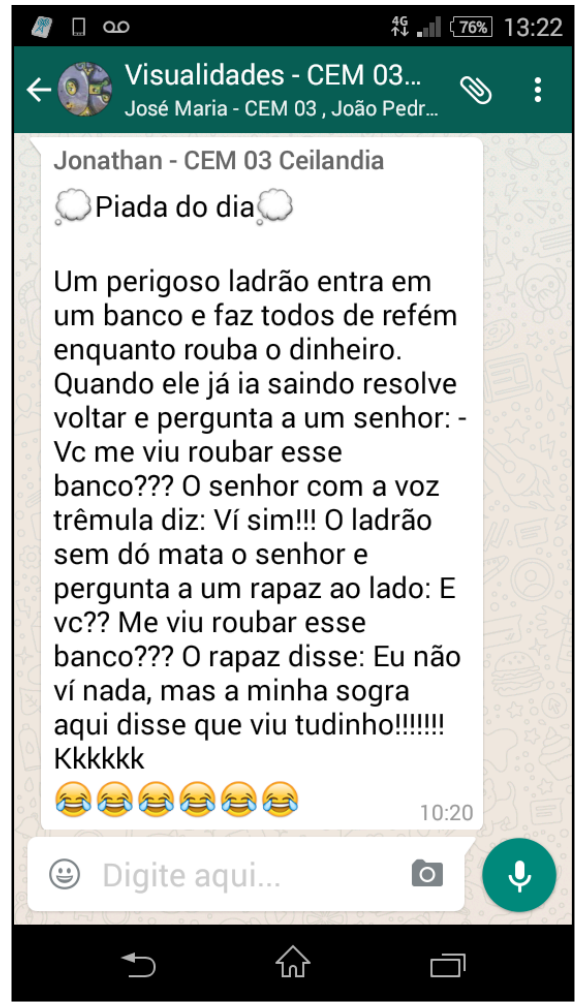

Figura 134. Mensagem do WhatsApp - aluno C-Seis. CEM 03 de Ceilândia-DF, 2015.

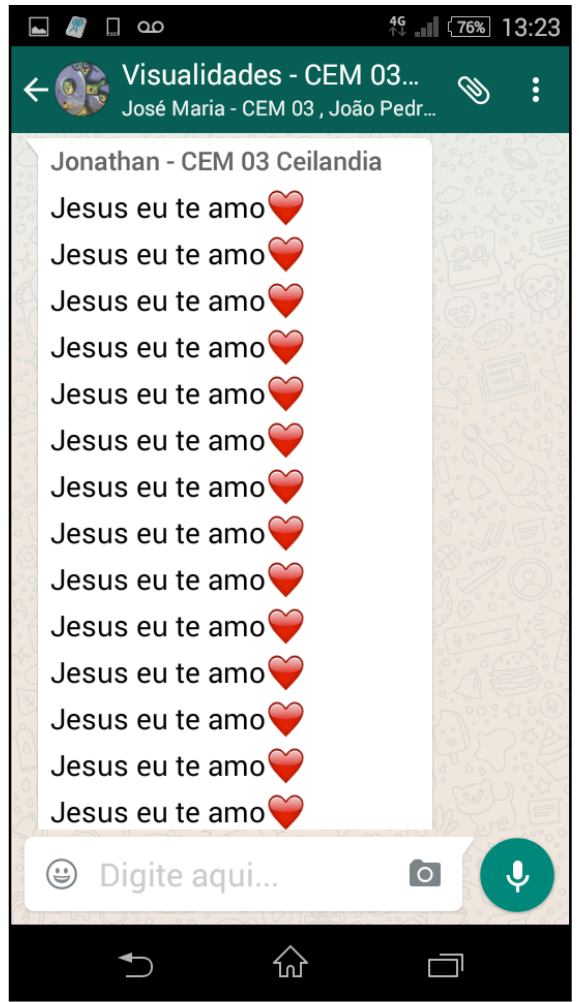

Figura 135. Mensagem do WhatsApp - aluno C-Seis. CEM 03 de Ceilândia-DF, 2015.

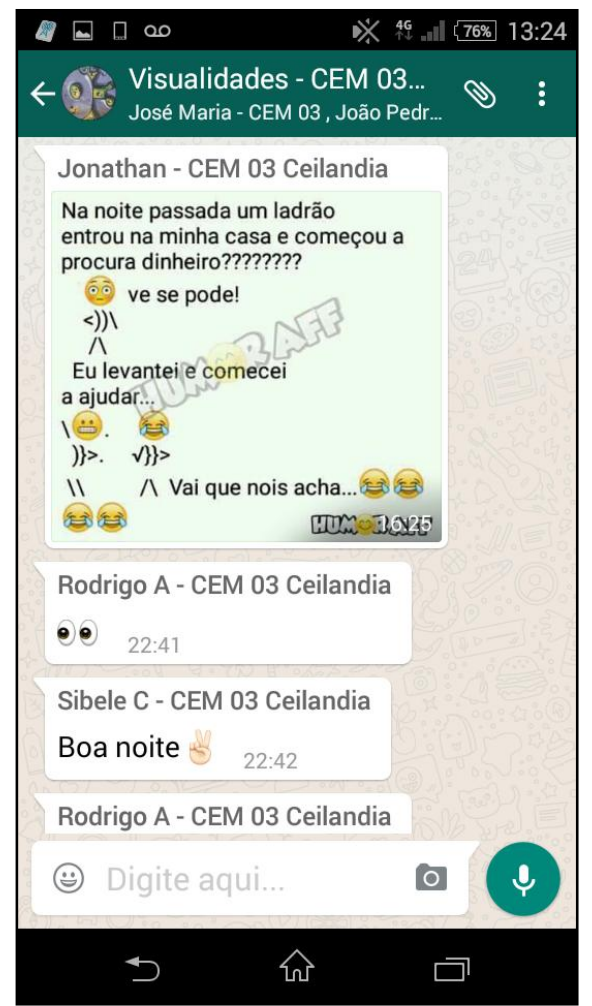

Figura 136. Mensagem do WhatsApp - aluno

C-Seis. CEM 03 de Ceilândia-DF, 2015. 


\subsubsection{Narrativa Visual - Aluno C-Quatro}

A narrativa visual do aluno C-Quatro é representada pelo desenho de uma escola, figura 137. É perceptível a cerca que separa a escola do restante do mundo. A escola possui árvores com frutos e caminhando entre as plantinhas duas crianças brincam afastadas das demais.

Em suas lembranças de infância, destacam-se alguns elementos constitutivos da trajetória escolar. Quem não se lembra da primeira escola, o primeiro dia de aula, a primeira professora, a hora do recreio e as brincadeiras com os colegas? Nas pequenas imagens uma vida pode ser mapeada com episódios fundamentais que contam mais do que uma vida, contam a vida de uma época, de um grupo, de um povo. Muitas pesquisas têm se apoiado na metodologia de histórias de vida, por acreditar que a experiência pessoal para o sujeito é um fator determinante na construção de sua compreensão do mundo e entendimento de si mesmo 57 .

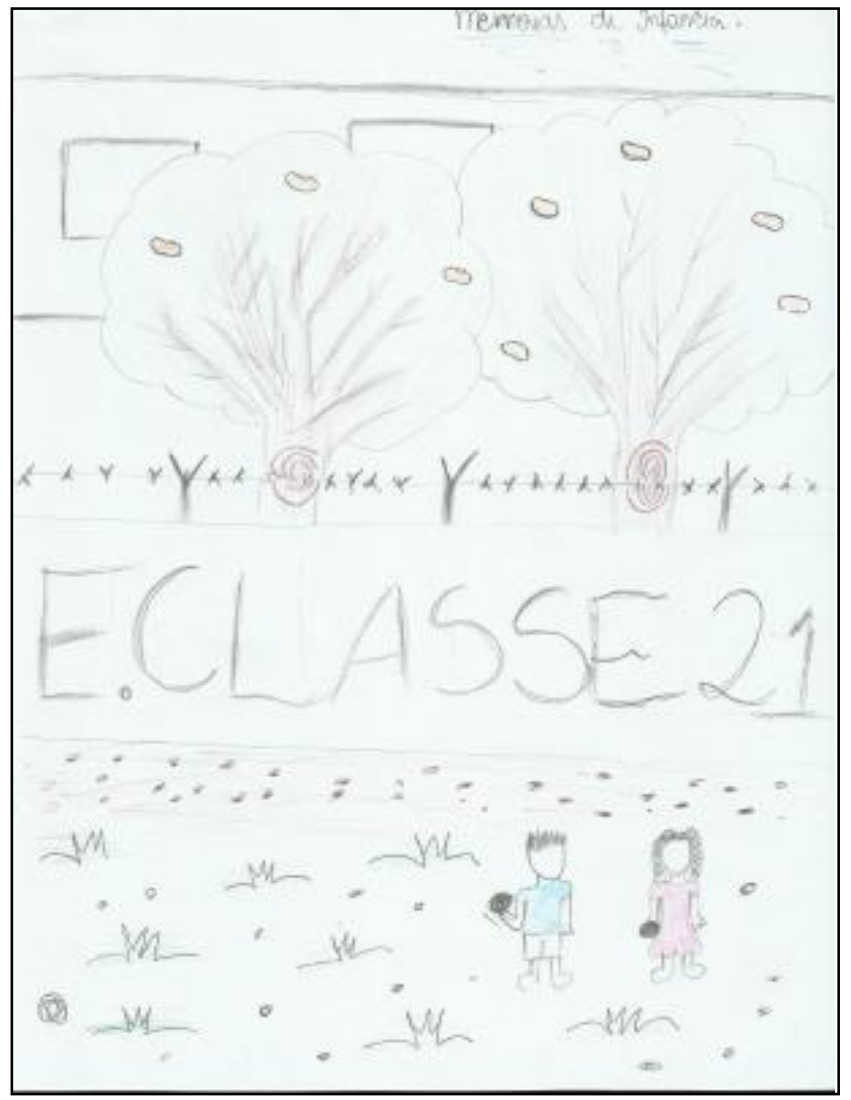

Figura 137. Lugares de lembrar a infância - aluno C-Quatro. CEM 03 de Ceilândia-DF, 2015.

\footnotetext{
57 Ver MORAES, Salete Campos. Escola, histórias e memórias: o que dizem jovens e adultos. I CIPA Congresso Internacional de Pesquisa (Auto) biográfica. Disponível em http://websmed.portoalegre.rs.gov.br/escolas/revistavirtualagora/materiais/salete.pdf. Acesso em fevereiro/2016.
} 
A narrativa do aluno abre caminho para outros tipos de pesquisas que ganham visibilidade e apontam para a diversidade de fontes e produtos estéticos, como a realizada por Cunha (2013) que buscou traçar diálogos entre imagens de uma mídia impressa e um grupo de alunos de um colégio estadual de Goiânia, procurando extrair narrativas das experiências do cotidiano de uma escola contemporânea. Nesse sentido, procurou apreender a narrativa dos alunos, a partir de conceitos da cultura visual, tendo a mídia como matriz de cultura na sociedade contemporânea, seus limites e suas possibilidades.

Sasso (2014) procurou entender a construção do conhecimento das visualidades a partir da fusão entre práxis, teoria e poética, relacionando a cultura, política e a dominação e/ou emancipação dos sujeitos. A pesquisa desenvolvida em uma cidade da periferia de Brasília, levou para a sala de aula assuntos relacionados ao cotidiano dos alunos. A intenção era tornar a escola um espaço de experimentação e criação capaz de estimular a consciência crítica e o empoderamento dos alunos em contextos socioeconômicos desfavorecidos. Em sua $\mathrm{A} / \mathrm{r} /$ tografia - aliança entre a artista, investigadora e educadora, observou a capacidade dos alunos em enfrentar desafios, de serem solidários no trabalho em equipe e o quanto eles eram sensíveis e afetivos em seus olhares sobre as pessoas e o mundo.

Na narrativa acerca da cidade o aluno preferiu sair da Ceilândia, figura 138, e se deter nas imagens de Brasília com seus monumentos e suas festas de elite, bem diferentes daquelas que acontecem na sua cidade.

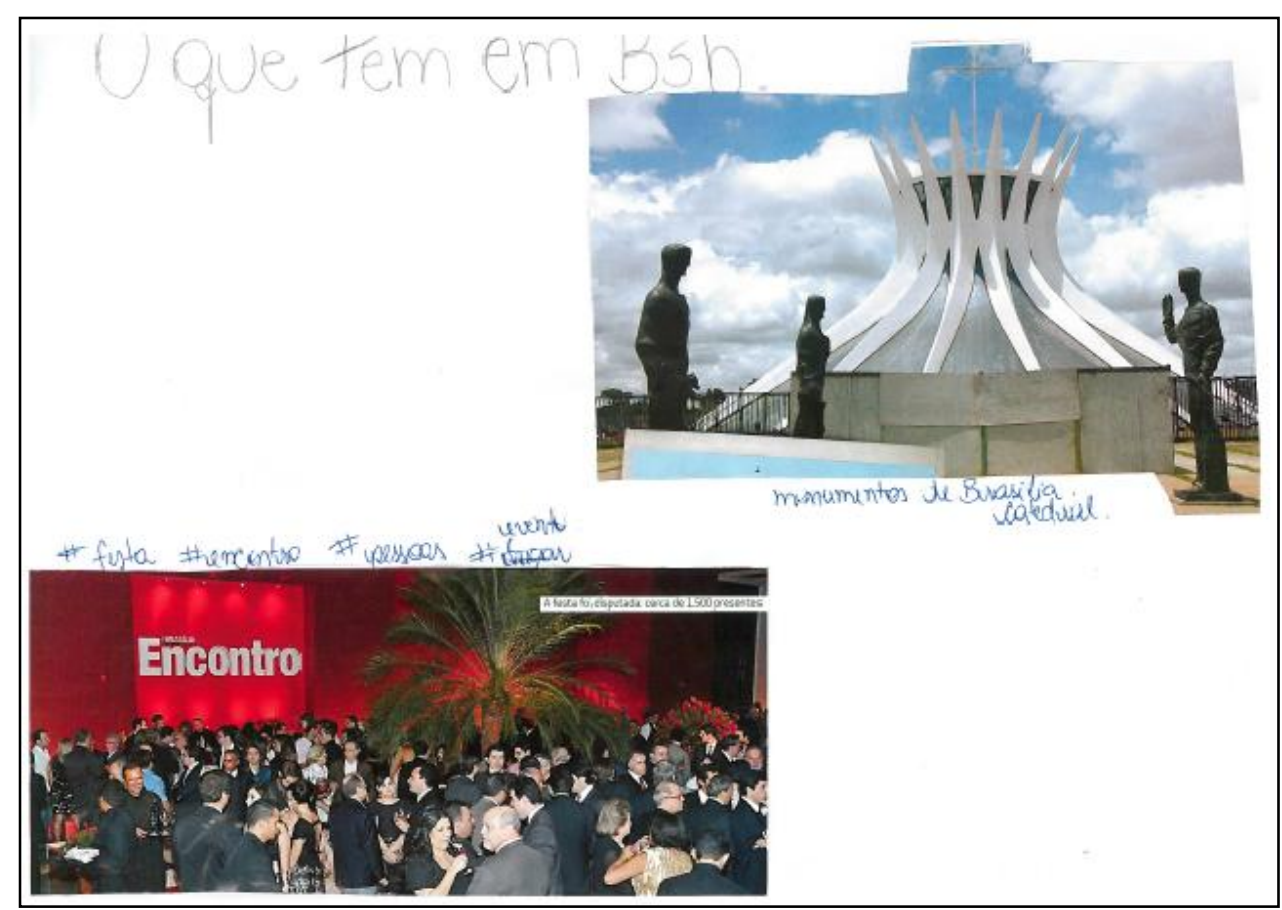

Figura 138. Lugares de lembrar a cidade e sua inserção - aluno C-Quatro. CEM 03 de CeilândiaDF, 2015. 
São produções de imagens-símbolos de Brasília como um grande projeto urbanístico associado a políticas culturais de identidade e de preservação do patrimônio histórico arquitetônico. Na verdade, o aluno desvela um espaço fragmentado e a produção de espaços seletivos, demonstrando como Carlos (2011, p. 69), que o espaço recria, constantemente, as condições gerais a partir das quais se realiza o processo de reprodução do capital, do poder e da vida humana, sendo, portanto, produto histórico e ao mesmo tempo realidade presente.

\begin{tabular}{|c|c|}
\hline \multirow{3}{*}{ 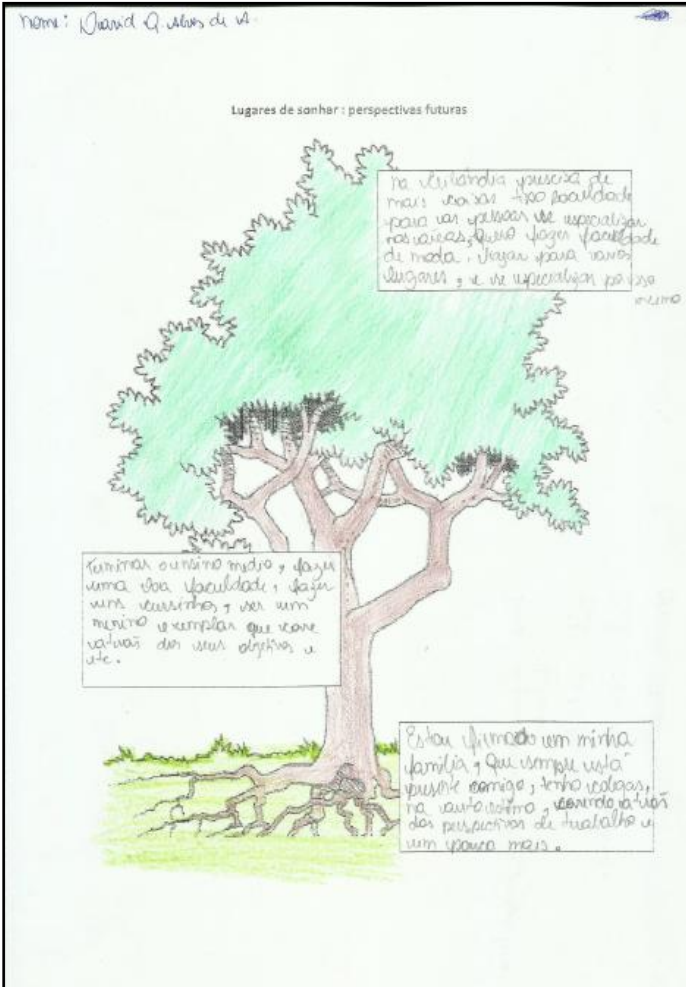 } & $\begin{array}{l}\text { Copa: Na Ceilândia precisa de mais coisas, } \\
\text { tipo uma faculdade para as pessoas se } \\
\text { especializarem nas áreas, quero fazer } \\
\text { faculdade de moda, viajar para novos } \\
\text { lugares, e se especializar para isso mesmo. }\end{array}$ \\
\hline & $\begin{array}{l}\text { Tronco: Terminar o Ensino Médio, fazer uma } \\
\text { boa faculdade, fazer uns cursinhos, ser um } \\
\text { menino exemplar que corre atrás dos seus } \\
\text { objetivos e etc. }\end{array}$ \\
\hline & $\begin{array}{l}\text { Raiz: Estou firmado em minha família, que } \\
\text { sempre está presente comigo, tenho colegas } \\
\text { na autoestima, correndo atrás das }\end{array}$ \\
\hline $\begin{array}{l}\text { zura 139. Lugares de so } \\
\text { no C-Quatro. CEM } 03\end{array}$ & perspectivas de trabalho e pouco mais. \\
\hline
\end{tabular}

Sobre as perspectivas futuras, figura 139, o aluno afirma que Ceilândia precisa de mais coisas, como uma faculdade para que as pessoas possam se especializar. No caso do aluno, ele pretende cursar uma faculdade de moda e conhecer vários lugares. Para atingir os seus objetivos ele pretende terminar o ensino médio, fazer uma boa faculdade e correr atrás de seus objetivos. Seus projetos estão firmados na família, nos amigos e na perseverança na vida profissional. 


\subsubsection{Narrativa Visual - Aluna C-Onze}

A narrativa da aluna C-Onze, figura 140, é o desenho de uma amarelinha em risco de lápis vermelho e de uma criança em uma proporção bem menor que o do desenho.

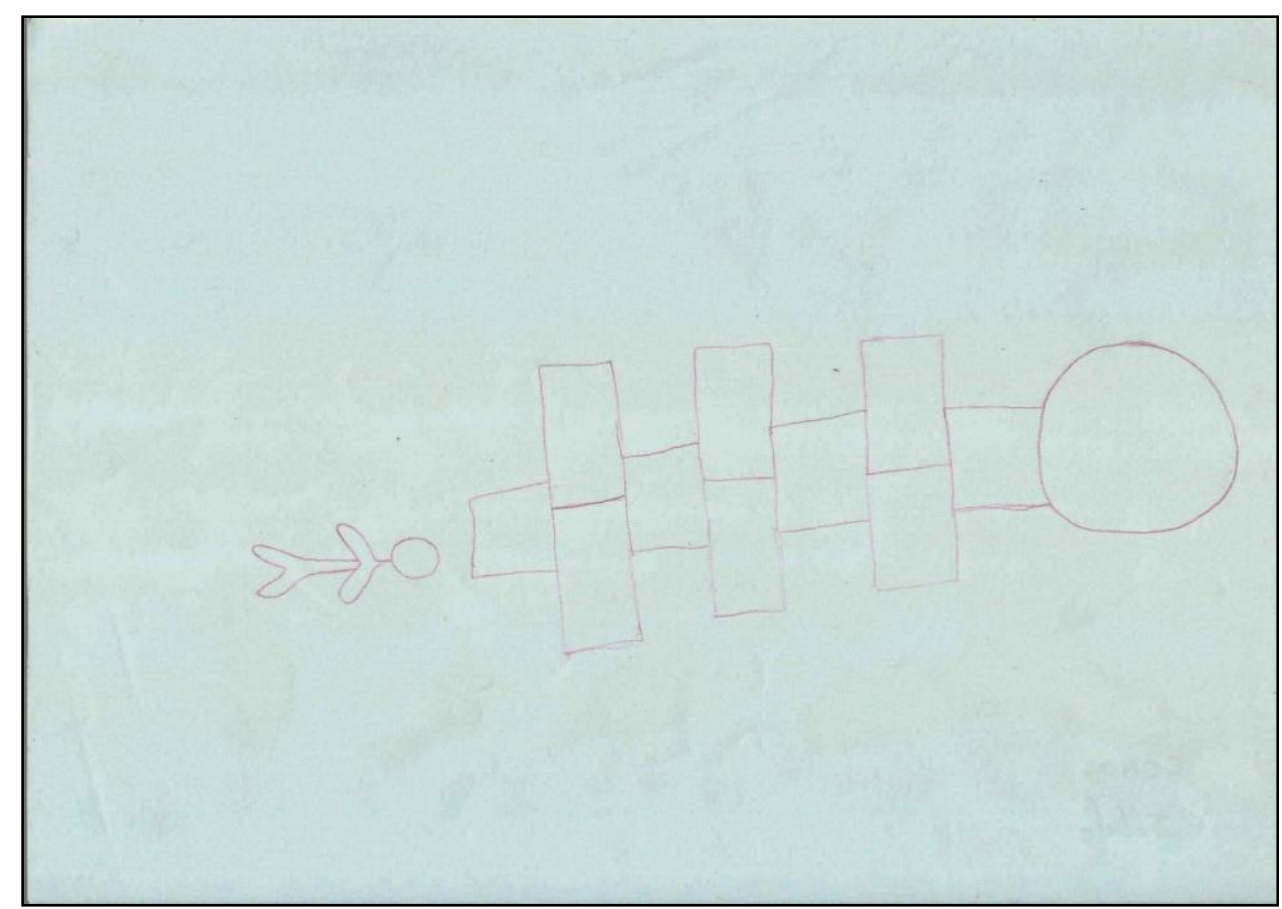

Figura 140. Lugares de lembrar a infância - aluna C-Onze. CEM 03 de Ceilândia-DF, 2015.

O desenho sugere que a criança brinca de pular amarelinha. A amarelinha é uma das brincadeiras de rua tradicional no Brasil e consiste em percorrer uma trajetória de quadrados riscados no chão de pulo em pulo, como um simbolismo da passagem do homem pela vida. Por isso, em uma das pontas se escreve céu e na outra, inferno. Existem gravuras que mostram crianças brincando de amarelinha nos pavilhões de mármore da Roma Antiga. A brincadeira foi inspirada nos treinamentos militares dos soldados romanos, quando as crianças imitavam a marcação que eles faziam no chão para treinar e pulavam para lá e pra cá ${ }^{58}$. Em seu estudo, Moreira (2013) analisa a contribuição da amarelinha para o desenvolvimento de habilidades matemáticas, como noções de números, de medidas e geometria, contagem, sequência numérica, reconhecimento de algarismos, comparação de quantidades, avaliação de distância e força, localização espacial, percepção espacial e discriminação visual nas crianças de 4 anos da educação infantil.

58 Informações disponíveis no site http://chc.cienciahoje.uol.com.br/amarelinha-e-outras-linhas/. Acesso fevereiro/2016. 
Apesar da criança aparecer só, a brincadeira geralmente é em grupo e reproduz a interação social descrita por Vigotsky (1984), como processos de aprendizagem e aprimoramento das estruturas mentais do homem desde o seu nascimento. Processo segundo o qual o ser humano necessita estabelecer uma rede de contatos com outros seres humanos para incrementar e construir novos conceitos. $\mathrm{O}$ outro social se torna altamente significativo para as crianças que estão no auge do seu desenvolvimento, uma vez que assume o papel de meio de verificação das diferenças entre as suas competências e as dos demais, para, a partir deste processo, formular hipóteses e sintetizar ideias acerca desses laços constituídos, tornando um processo interpessoal, num processo intrapessoal.

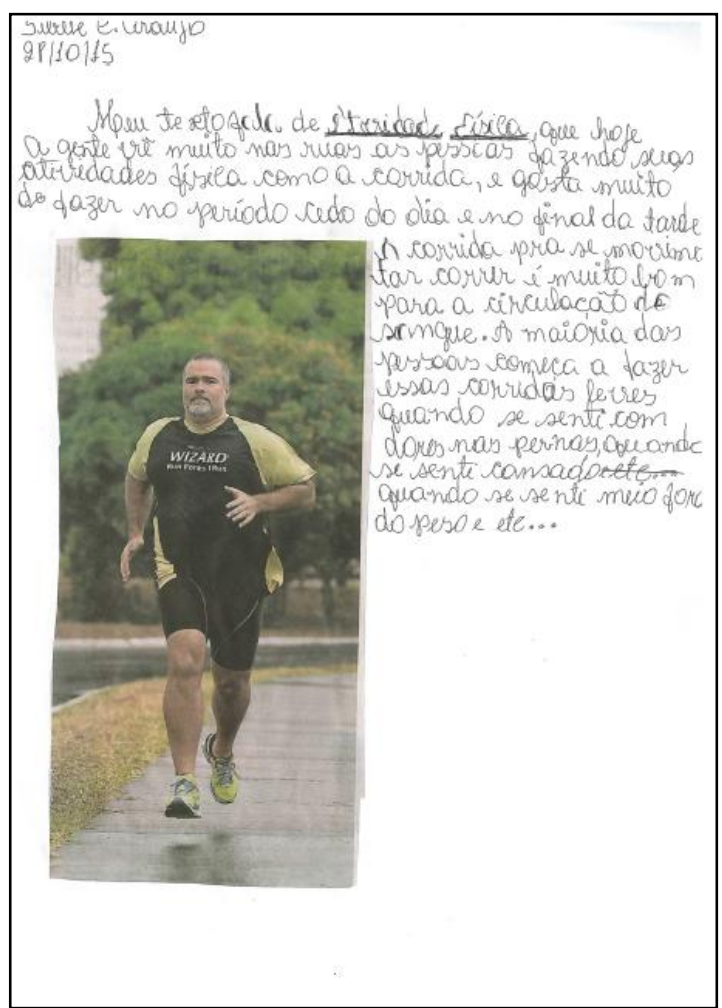

Figura 141. Lugares de lembrar a cidade e sua inserção aluna C-Onze. CEM 03 de Ceilândia-DF, 2015.
Meu texto fala de atividade física que hoje a gente ver muito nas ruas as pessoas fazendo suas atividades físicas como corrida, e gosta muito de fazer no período cedo do dia e no final da tarde.

A corrida para se movimentar, correr é muito bom para a circulação do sangue. A maioria das pessoas começa a fazer essas corridas leves quando se senti com dores nas pernas, quando se senti cansado e etc... quando se senti meio fora do peso e etc.

Sobre a narrativa da cidade, a aluna associa texto escrito e imagético, figura 141. Em seu texto fala dos benefícios da atividade física e estética para o corpo humano. A imagem reforça o que está sendo dito com a figura de um homem correndo. Em sua descrição o espaço urbano aparece de forma harmônica, possibilitando a convivência entre os cidadãos, com o respeito ao espaço de todos. Aqui temos uma espécie de parque urbano que associa práticas esportivas, educativas, culturais, artísticas ou ambientais. Esses espaços permitem a 
socialização e a contemplação de fragmentos da natureza, capazes de romper com o cotidiano do concreto.

Nas suas perspectivas futuras, figura 142, a aluna afirma a pretensão de terminar o ensino médio e cursar uma faculdade. Para realizar os seus objetivos pretende arrumar um trabalho. A sua raiz parece frágil ao afirmar que Ceilândia precisa de coisas que ainda não tem.

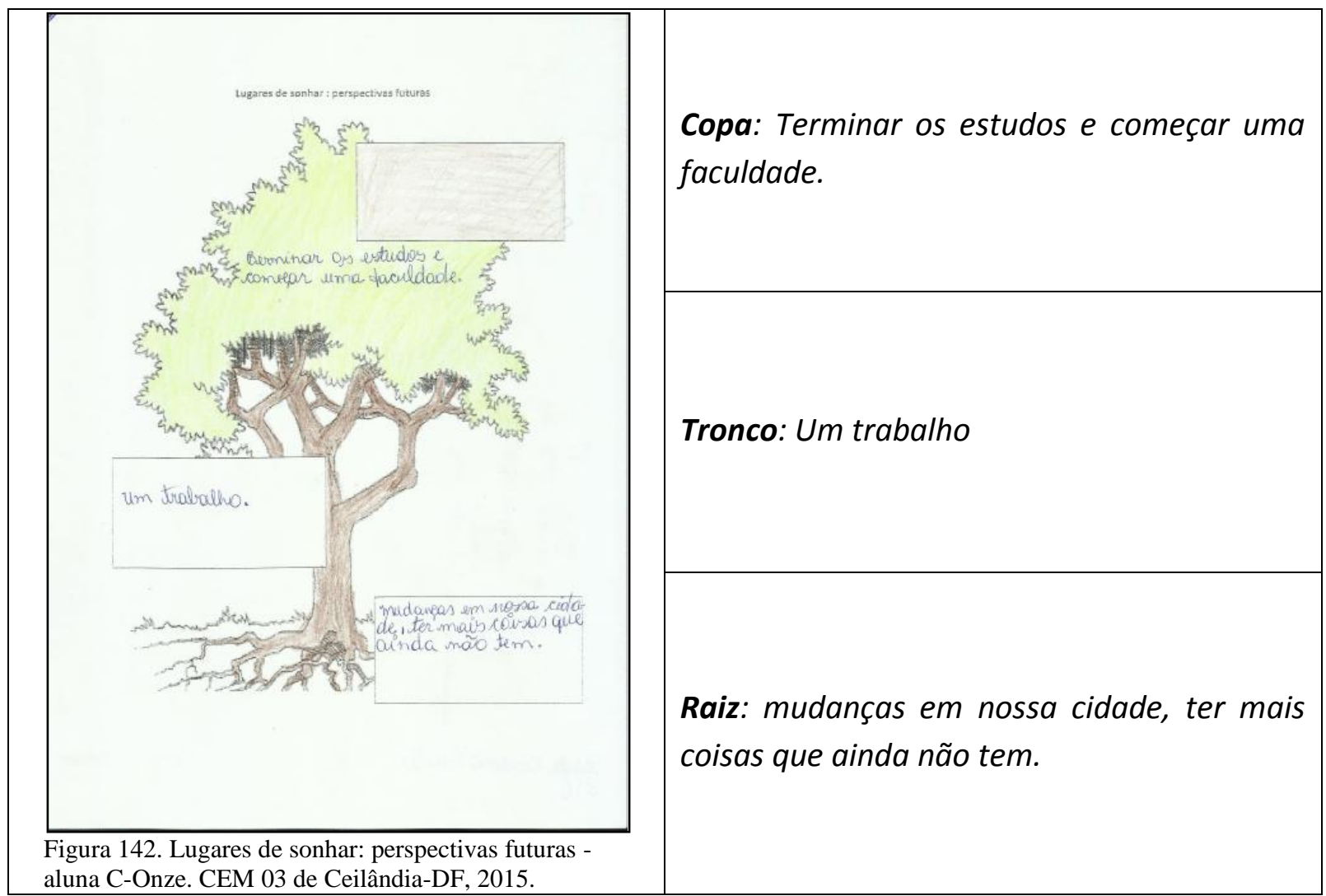

\subsubsection{Narrativa Visual - Aluno C-Dois}

A narrativa do aluno C-Dois sobre a infância, figura 143, é entremeada por desenho e escritas. O desenho sugere que o aluno joga bola e anda bicicleta com seus três grandes amigos de infância. No texto escrito fala do controle dos pais e das brincadeiras favoritas. Lembra-se do presente que ganhou do padrinho (a bicicleta). Essa narrativa reforça as ideias de Vigotsky de que "o comportamento do homem é formado por peculiaridades e condições biológicas e sociais do seu crescimento" (2001, p. 63). Possivelmente, na lembrança da infância, o aluno C-Dois deve ter aprendido com seus colegas (Wendel, Leandro e Marquinhos) o senso de certo e errado, a adequação ou não às regras do jogo de futebol, a 
andar de bicicleta, subir na árvore, dentre outros. Com isso, a criança vivencia experiências, conceitos, valores e ideias do seu meio cultural e social.

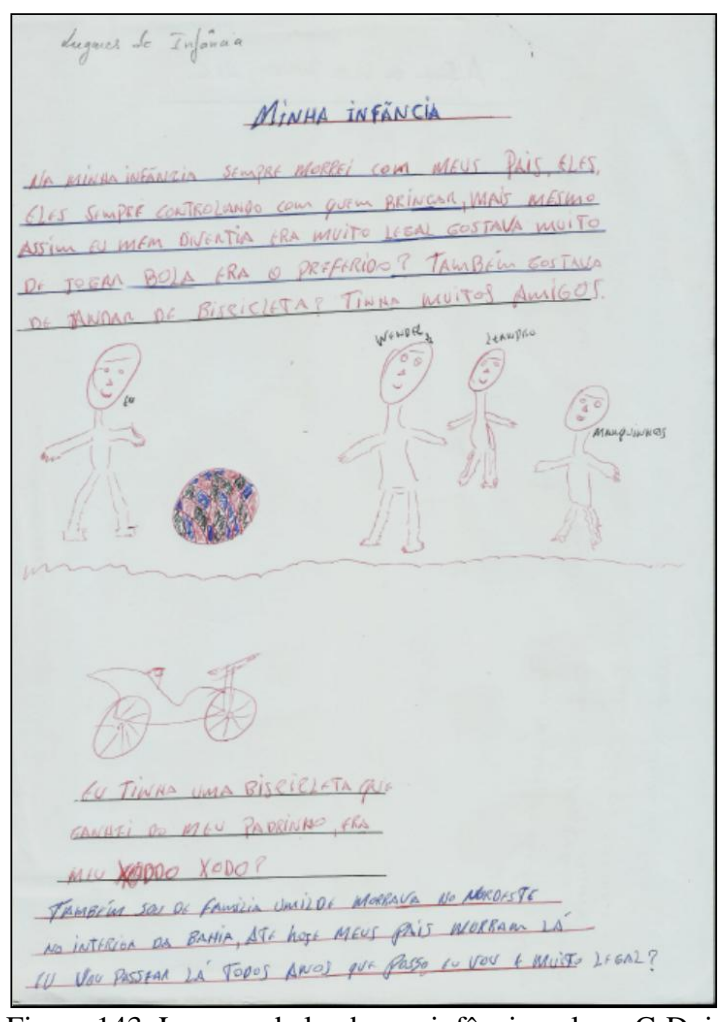

Figura 143. Lugares de lembrar a infância - aluno C-Dois CEM 03 de Ceilândia-DF, 2015.

Minha Infância
Na minha infância sempre morrei com meus
pais, eles sempre controlando com quem
brincar, mais mesmo assim eu me divertia
era muito legal gostava muito de jogar bola
era o preferido? Também gostava de andar
de bicicleta? Tinha muitos amigos.
Eu, Wendel, Leandro, Marquinhos.
Eu tinha uma bicicleta que ganhei do meu
Padrinho, era o meu xodó?
Também sou de família humilde morava no
nordeste no interior da Bahia, até hoje meus
pais morram lá
Eu vou passear lá todos os anos que posso
eu vou e muito legal?

Ao falar sobre a cidade, o aluno continua a sua narrativa pautada em um texto escrito e imagético. Por um lado, a imagem de uma jovem que sorri e oferece uma flor para a câmera. No texto escrito reproduz fragmentos do cotidiano que ilustram as contradições entre os espaços urbanos no Brasil, ao apresentar as seguintes características: modernização conservadora, industrialização truncada e incompleta e urbanização desigual, sem urbanidade, com travamento e interdição do acesso aos direitos para a maioria da população. Segundo estudo de Brandão (2015), forças sociais heterogêneas esculpiram no território nacional uma das sociedades mais desiguais, excludentes e predatórias. Uma nação com construção travada, tendo no núcleo de seu poder uma das elites mais conservadoras e retrógradas já existentes na história mundial e uma imensa massa populacional destituída de direitos, cidadania plena e acesso adequado a bens e serviços coletivos. 


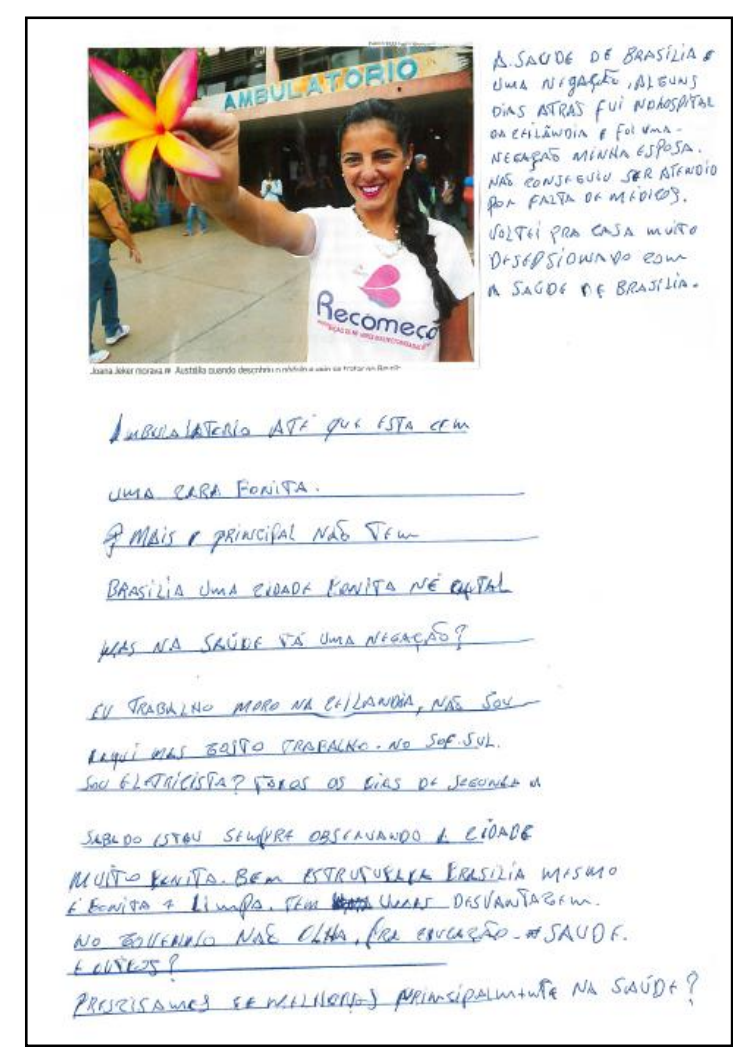

Figura 144. Lugares de lembrar a cidade e sua inserção aluno C-Dois. CEM 03 de Ceilândia-DF, 2015.
A saúde se Brasília e uma negação. Alguns dias, atrás fui ao hospital da Ceilândia, e foi uma negação minha esposa não conseguiu ser atendida por falta de médicos. Voltei para casa muito decepcionado com a saúde de Brasília.

Ambulatório até que esta com uma cara bonita. Mais o principal não tem Brasília uma cidade bonita né capital, mas na saúde tá uma negação. Eu trabalho, moro na Ceilândia, não sou daqui mas gosto trabalho no SOF-SUL.

Sou eletricista. Todos os dias de segunda a sábado estou sempre observando a cidade muito bonita. Bem estruturada Brasília mesmo é bonita e limpa. Tem uma desvantagem. No governo não olha pra educação, saúde e outros? Precisamos de melhoras principalmente na saúde?

Outra narrativa, figuras 144 e 145, sugere que o aluno é integrante da classe menos favorecida da sociedade, esta é reforçada por seu cotidiano. O aluno exerce a profissão de eletricista industrial no Setor de Oficinas (Brasília) e mora na Ceilândia. Para chegar ao trabalho, tem que acordar muito cedo. No retorno do trabalho, vai para a escola, chegando em casa para descansar muito tarde. O aluno olha pela janela do ônibus e percebe que Brasília é uma cidade bem estruturada, limpa e bonita, em oposição à péssima oferta de saúde e educação da cidade onde mora. 


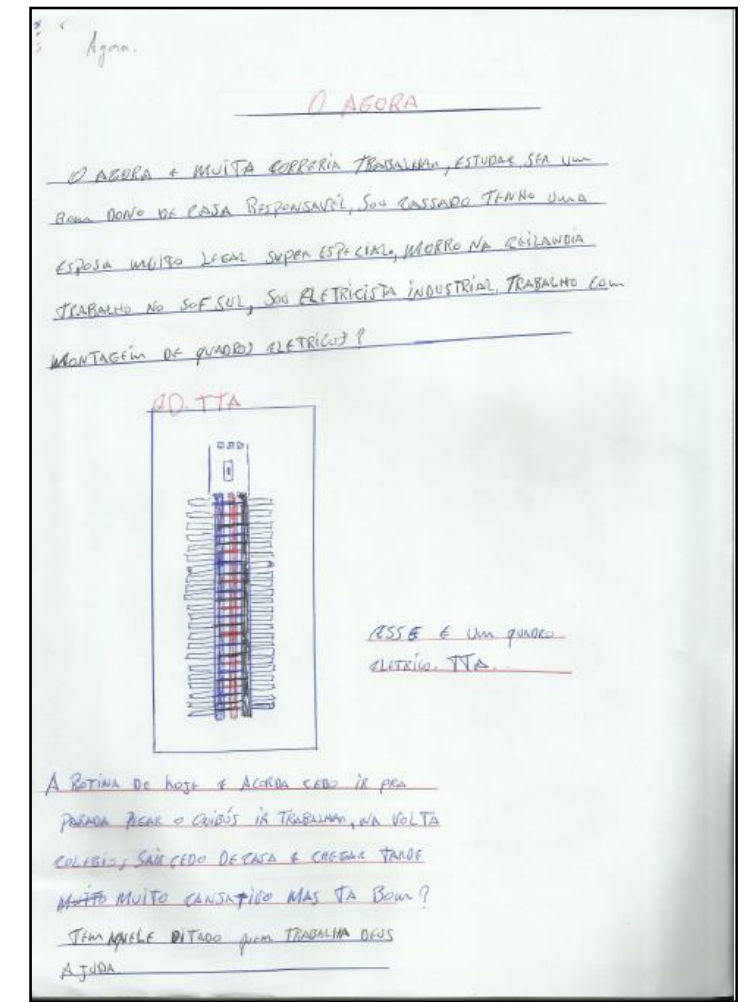

Figura 145. Lugares de lembrar a cidade e sua inserção aluno C-Dois. CEM 03 de Ceilândia-DF, 2015.

O Agora
O agora é muita correria, trabalhar, estudar,
ser um bom dono de casa, responsável. Sou
casado, tenho uma esposa muita legal,
super especial. Moro em Ceilândia, trabalho
no sOF sul, sou eletricista industrial.
Trabalho com montagens de quadros
elétricos.
Esse é um quadro elétrico. TTA
A rotina de hoje é açodar cedo ir para a
parada, pegar o ônibus, ir trabalhar. Na
volta, ir para o colégio, sair cedo de casa e
chegar tarde. Muito cansativo, mas tá bom.
Tem aquele ditado: quem trabalha Deus
ajuda.

Sobre seus planos futuros o aluno, figura 146, o aluno é firme em seus propósitos: pretende fazer engenharia elétrica. Apesar de já possuir uma profissão com a qual se identifica e tem boas relações de amizade, deseja melhorar e alçar voos maiores. O seu texto sobre a base de sustentação sugere uma família firmada na religião que caminham juntos na construção de vidas. 


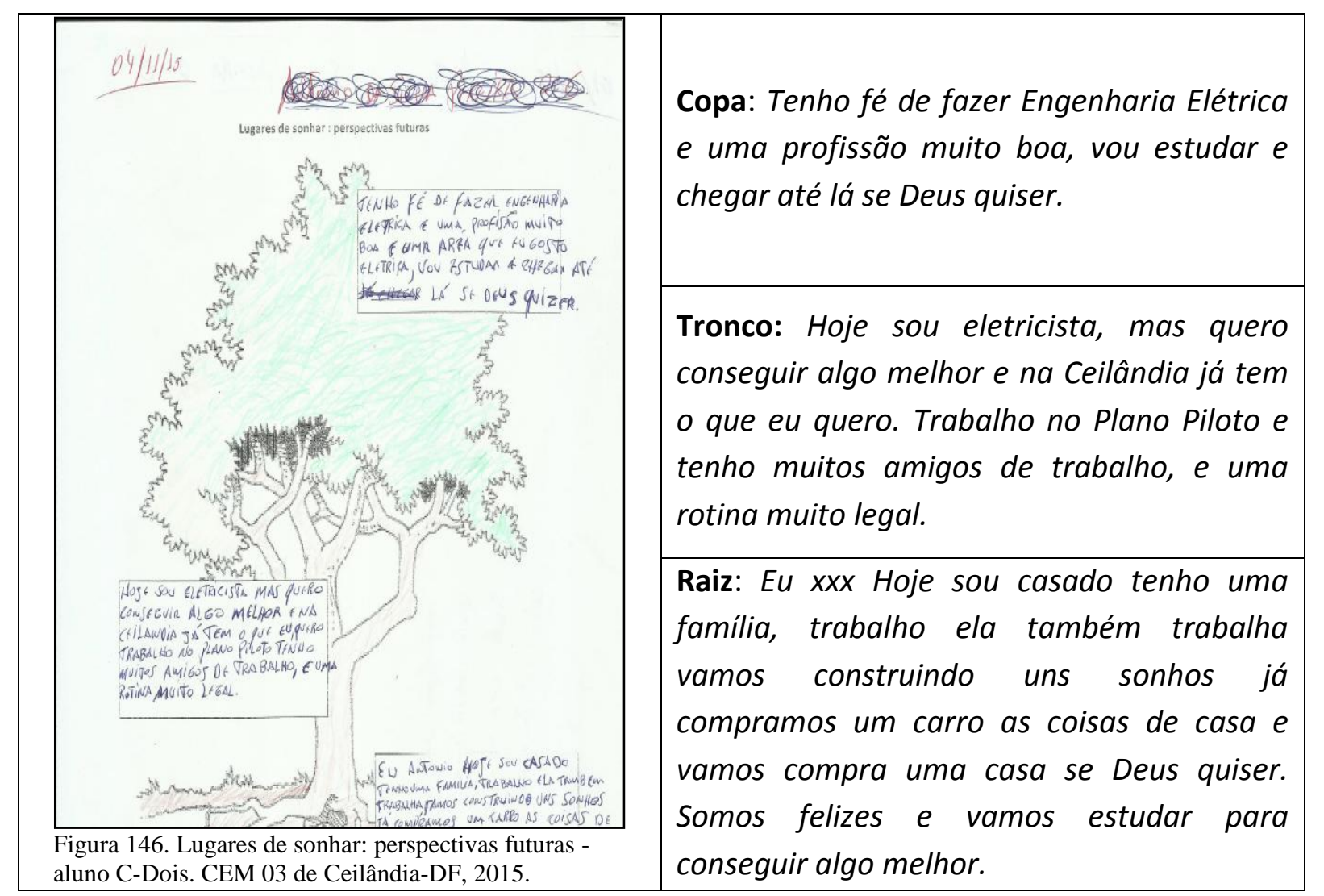

A narrativa do aluno pode se comparar ao estudo desenvolvido pelo Laboratório de Estudos sobre Cidades, Culturas Contemporâneas e Urbanidades da Universidade Federal da Paraíba (LECCUR/UFPB - 2015), que reúne fotos registradas por caminhantes em diversos bairros da cidade de João Pessoa/PB. O ensaio fotográfico procurou apreender a visão do pedestre acerca do espaço urbano produzido pelas atuais gestões públicas. As imagens foram orientadas pelas seguintes categorias: insegurança, desconforto, proteção, convívio e surpresa. A conclusão é que as imagens são fragmentos que revelam problemas importantes observados no cotidiano da cidade, bem como o descaso do poder público frente às exigências qualitativas condizentes com um espaço bem equipado, acessível e confortável, colocando o pedestre em situação de vulnerabilidade. Elas também descortinam um pedestre em constante adaptação ao mundo contemporâneo.

Em outro contexto, Victorio Filho (2011) explorou a esfera visual que atua independente da materialidade tangível e reconfigura a cidade enquanto espaço e tempo cruciais dos coletivos humanos. É o que denomina "cidade-tudo" - organização política, instalação social, cenário poético e tantas outras coisas que convivem em uma mesma dinâmica espaço-temporal, um mundo a um só tempo local e planetário. Para o autor, “sujeição, aviltamento, maravilhamento, gozo e dor são igualmente elementos constitutivos da 
cidade-tudo" (Victorio Filho, 2011, p. 193). Nela, homens e mulheres habitam com suas diversas culturas, seus abrigos identitários, suas linhas de fuga e seus sistemas de clausura, exclusão e pertencimento. Nessa cidade que é imaginal, é imagética, é visualidade e em permanente virtualização, que emerge a necessidade de uma educação visual e uma ressignificação estética do mundo e das relações sociais.

As referências citadas no decorrer do texto ilustram a aproximação do conceito de arte do cotidiano e de contextos sociais. Para Martins (2008), essa transformação está relacionada à fermentação e geração de ideias dos anos 1960, com seus movimentos: arte pop, arte conceitual, performance, instalações, arte ambiental, dentre outras, que intensificaram a resistência às polaridades do sistema das belas artes e buscaram aprofundar a relação arte e vida $^{59}$.

Com essa mudança nas artes visuais, o olhar do expectador/intérprete adquire uma dimensão cultural e a imagem passa a ser considerada não apenas em seus valores estéticos, mas sim em seu papel social. Na perspectiva de Bourriaud (2009), as práticas artísticas tomam como ponto de partida teórico e prático o grupo das relações humanas e seu contexto social. O artista passa a ser um semionauta que inventa trajetórias entre signos, conectando diferentes formas artísticas. A arte está presente em tudo, aproximando-se cada vez mais do cotidiano das pessoas, revelando aspectos ocultos da sociedade que, segundo Hernández (2007, p.35), “expõe o mundo tal qual ele é: sobre o mundo real, sobre os meios, os pobres, a rua, a música, as drogas".

\footnotetext{
${ }^{59}$ Bourriaud denomina a configuração da arte após os anos de 1990 de estética relacional que se caracteriza por serem obras de arte relacional, pois promovem encontros intersubjectivos, cujos significados são construídos coletivamente e não numa esfera de consumismo individual. Ao contrário de uma obra autônoma que transcende o seu contexto, a arte relacional está condicionada ao seu ambiente e ao seu público. A relação obra de arte/espetador sofre uma transformação, no sentido em que o espetador já não observa a obra do exterior, mas passa a integrá-la, inserindo-se no coletivo, criando uma comunidade com carácter temporário ou utópico.
} 


\section{COSTURANDO AS NARRATIVAS VISUAIS DOS ALUNOS}

Após as leituras e compreensões das vinte e uma das narrativas visuais produzidas pelos alunos de EJA sobre os espaços urbanos na perspectiva da cultura visual, costura-se enfim a resposta da pergunta a que se destina a pesquisa: Como os alunos da Educação de Jovens e Adultos interagem com as visualidades cotidianas? Como estas visualidades influenciam a leitura dos espaços que vivem?

Sob essa perspectiva, compreendeu-se que as imagens invadem nosso cotidiano e que o mundo visual em que vivemos captura composições imagéticas que atuam como uma forma de produzir ensinamentos e constituir subjetividades. Assim como, essas composições imagéticas, veiculadas nas páginas da internet, nas revistas, propagandas, programas de TV, dentre outros, carregam significados que alimentam as narrativas sobre o passado, presente e futuro dos alunos.

Foi como o semionauta ${ }^{60}$ de Bourriaud que se percorreu os signos apreendidos na pesquisa com os alunos, procurando encontrar conexões entre eles. São as conexões rizomáticas de Deuleze e Guatarri (apud Martins 2008, p. 32) "que articulam a dissolução de espaços originários e de identidades autênticas, noções herdadas da modernidade com a pretensão de carregar verdades insondáveis sobre arte, ciência, história e realidade”.

Perspectiva semelhante, Michel de Certeau ensinou que "toda reflexão acerca da sociedade deve retornar ao seu início, com uma atenção preparada para a surpresa. [...] ensinam que as revoluções do crível não são necessariamente reivindicadoras" Certeau (2016, p. 35). Nesse sentido, falar de práticas, de criações e artes na escola é pensar o cotidiano, no seu fazer e na busca da compreensão de suas regras próprias.

Nas visualidades produzidas referentes às narrativas "Lugares de lembrar a infância" foi possível observar uma diferença nítida dos espaços do brincar. Enquanto em Planaltina predominou a visão de um espaço geográfico aberto e ruralizado; Ceilândia foi possível enxergar a evocação de uma paisagem urbana em espaços fragmentados, sem padrão e sem efeito estético que exprimiu os extremos de uma sociedade dividida. Essas narrativas visuais produziram imagens cujos conteúdos foram capazes de fornecer formas de compreensão da realidade cultural e social dos espaços urbanos.

Nas visualidades dos alunos prevaleceram imagens de menino e de menina associadas com determinado tipo étnico e padrões de cores. Ao narrarem sobre as suas brincadeiras, os

60 A noção de forma-trajeto descrita por Bourriaud como uma estratégia artística de navegação em meio a paisagem de signos, na qual o artista é compreendido como um semionauta. 
meninos referiram-se constantemente às brincadeiras como pipa, jogos de futebol, bete e bolinha de gude. As meninas reproduziram as brincadeiras de boneca e de casinha. A visão de masculinidade e feminilidade no espaço infantil foi ignorada a diversidade de gênero, raça e religião em suas narrativas.

Segundo Cunha (2012), as imagens colam nas crianças como se fossem suas peles. Dessa forma, as narrativas produzidas pelas alunas, às meninas eram brancas, loiras e de olhos azuis foram às princesas e os meninos eram ágeis, fortes foram os super-heróis. Assim, o colega que estivesse fora do padrão, nesses modelos pré-estabelecidos, foram excluídos.

Deduziu-se que a narrativa de infância dos alunos, que essa invisibilidade de crianças com caracteres afrodescendentes e/ou indígenas decorrem de um processo histórico cultural de "branqueamento" da população e da sedimentação de preconceitos e estereótipos que os inferioriza.

Em suas visualidades os alunos criaram e refletiram reproduções de personagens infantis, como os personagens da Turma da Mônica e dos desenhos da Disney, geralmente produzidas como observa Hernández (2010, apud Reis, 2016, p.5-6), “em diferentes contextos históricos, institucionais e discursivos".

As narrativas sobre a infância deixaram claras que havia separações entre as brincadeiras de meninos e de meninas. Enquanto as dos meninos representaram o estereótipo masculino de virilidade; as meninas representaram brincadeiras dóceis e delicadas, como casinha, boneca, maquiagem amarelinha e bolinhas de sabão, demonstraram com isso, os estereótipos determinado por papéis sociais que cada criança deveria ocupar. Confirmando o que diz Martins (2008, p.31) de que "o olhar está traspassado por condições e referentes que se superpõem como classe, raça, idade, estilo de vida, preferências sexuais e muitas outras".

Num primeiro momento, as narrativas dos alunos em "Lugares de lembrar a cidade", os alunos evidenciaram as diferentes percepções das realidades ambientais entre as cidades: Planaltina como um campo, cujo modelo de vida sensível e espiritual tendo um ritmo mais lento e regular, em oposição à Ceilândia com a diversidade de impressões sensoriais e da intensidade dos estímulos, bem como a aceleração geral do tempo. Entretanto, essas visões foram invertidas nas narrativas, ao apresentarem uma intensa violência urbana na cidade de Planaltina em oposição aos diversos espaços de convivência social apresentadas pela cidade de Ceilândia.

Os estudos realizados por Leonardo Charréu (2007), Imagem global e cultura visual: sobre o que se pode aprender no espaço mediático apontam a existência de uma violência 
institucionalizada e espetacularizada cotidianamente pela televisão. Essas imagens veiculadas diariamente nas mídias é o que podemos designar de "banalização do mal". Para o autor, "os jovens encontram-se imersos numa difusa e complexa cultura mediático-consumista, e esta cultura de contornos mal definidos é o lugar existencial absoluto onde vive a maior parte dos jovens" Charréu, (2007, p. 192). A visão do autor está refletida nas narrativas visuais que expõem a violência da cidade de Planaltina, remetendo aos altos índices de criminalidade.

Nos percursos para às escolas foi possível perceber as diferenças entre as cidades, Planaltina se apresentava verde, aberta e rural, era possível enxergar o horizonte em quase todos os pontos da cidade. Mesmo sendo exposta às interferências urbanísticas, tais como o excesso de automóveis e a proliferação de invasões com suas casas pobres e precárias, ainda conserva sua história centenária e suas tradições religiosas.

Em Ceilândia a realidade se apresenta diferente, a cidade possui uma dinâmica diversa, tem pressa, é iluminada parece que estar sempre em festa, uma cidade dormitório, sempre em expansão.

Ao interpretar suas narrativas de cidade, os alunos deixaram vislumbrar aspectos dessa realidade observada nos percursos, com suas árvores e flores, com as brincadeiras de ruas em espaços intermináveis e pela ausência de eventos culturais, em Planaltina. Ceilândia é tudo junto, com a ausência de espaços para brincadeiras, com suas invenções e reinvenções de brinquedos, e em seus eventos musicais e feiras populares.

Foi observada a cidade como uma espécie de organismo vivo, em suas paisagens que compõem as ruas, avenidas, monumentos e edifícios, que se apresentam como partes de um cenário pronto para ser decifrado em suas relações sociais existentes em seu interior e em suas polifonias. A cidade-tudo é interpretada por Victorio Filho, "Mais do que a localização dos corpos físicos de seus habitantes, a cidade-tudo é marginal, é imagética, é visualidade em permanente virtualização" Victorio Filho (2007. P. 194). Tanto Planaltina, quanto Ceilândia abrigaram palavras, coisas e corpos em sua arquitetura e paisagem que foram se configurando e se reconfigurando; incorporando e reincorporando as vidas e histórias de seus habitantes. Nesse contexto, as visualidades foram cúmplices das cidades, retratando-as e transformandoas pelos olhares dos alunos.

Esse foi o entendimento de Lynch $(1999$, p. 4) ao afirmar que "a imagem urbana é o quadro mental generalizado do mundo físico exterior de que cada indivíduo é portador. Sendo esta imagem produto da sensação imediata e da lembrança de experiências passadas”. Nesse sentido, as cidades se constituíram como um enredo de signos que produziram informações. 
As narrativas sobre o tema "Lugares de sonhar: perspectivas futuras" dos alunos, enquanto foram lidas e compreendidas as visualidades, veio à mente o conceito de habitus concebido por Pierre Bourdieu, ao compreender as condições objetivas que caracterizam a posição do indivíduo na estrutura social. Na pesquisa desenvolvida na Argélia, nos anos 1950 e 1960, Bourdieu (2007), observou a situação de desamparo dos migrantes rurais submetidos a um ambiente urbano e capitalista. Para compreender o comportamento e as práticas desses indivíduos, o autor concebeu o conceito de habitus como princípio mediador entre as práticas individuais e as condições sociais de existência. Um conceito capaz de sistematizar a oposição aparente entre a realidade exterior e as realidades individuais, a expressão do diálogo e da troca constante e recíproca entre o mundo objetivo e o mundo subjetivo das individualidades. O habitus foi concebido como um sistema de esquemas individuais, socialmente constituído de disposições estruturadas (no social) e estruturantes (nas mentes) adquirido nas e pelas experiências práticas, em condições sociais específicas de existência, constantemente orientado para funções e ações do agir cotidiano.

O conceito de habitus se tornou importante para verificar como são produzidas e reproduzidas as práticas engendradas pela história do indivíduo e de sua coletividade. Esse sistema de disposições sociais é incorporado pelos indivíduos sob as influências familiar/social, que reproduzem características de um grupo nas suas formas objetivas e subjetivas. Nessa perspectiva, “os indivíduos nunca são sujeitos absolutos de suas práticas, visto que o habitus de classe se inscreve e materializa os modos de ser, fazer e pensar dos sujeitos” Bourdieu (2007, p. 102).

A partir deste conceito desenvolvido por Bourdieu (2007) observou-se que a maioria dos alunos de Planaltina e Ceilândia acredita que o término do ensino médio e o ingresso em uma faculdade é o ápice de sua realização, completada pela constituição de uma família, a aquisição da casa própria e outros bens. Este entendimento se evidencia o mascaramento das diferenças sociais que disfarça preconceitos, discriminação e reprodução de vantagens sociais, que perpetuam as diferenças de classes e privilégios sociais.

Foi possível identificar, permeando os textos dos alunos, uma realidade de exclusão, desigualdade e omissão do Estado, principalmente, entre os jovens nos quais incide maior vulnerabilidade social, exigindo investimento social que possa minimizar a vulnerabilidade a que estes jovens estão submetidos e que pode facilitar a entrada de crianças e adolescentes no mundo do crime. 
A ideia foi confirmada por estudos, como por exemplo, os de Castro e Abramovay (2002), que alertam para a situação de vulnerabilidade dos jovens quanto ao trabalho, sendo esse um dos contingentes populacionais que apresentam as mais altas taxas de desemprego e de subemprego no país e que demandam novos enfoques da educação e qualificação profissional, não acessível aos jovens de famílias pobres, como conhecimentos em informática e línguas estrangeiras.

Em contextos de desigualdades é comum o desenvolvimento de conflitos sociais, uma vez que os atores praticam o exercício do direito, que não é individual, mas sim um esforço coletivo pela formação de direitos coletivos. Possivelmente, este tenha sido o motor para as manifestações de junho de 2013, que eclodiram no Brasil, como uma onda de protestos populares que tomou conta das ruas da maioria das cidades do país. Tais manifestações tiveram início com os estudantes se mobilizando contra o aumento da tarifa do transporte público, e foram ganhando novas e diferentes bandeiras reivindicatórias, como qualidade dos serviços públicos de saúde e das escolas e universidades públicas, contra a realização de megaeventos esportivos e contra a corrupção na política, dentre tantas outras. Lembrando que a parcela da população que saiu às ruas durante as manifestações de junho de 2013 , era, em sua maioria, formada por jovens estudantes que dominam o uso das tecnologias de informação e comunicação. O uso desses meios no mundo virtual transbordou os fóruns de discussão na internet e redes sociais e determinou a ocupação das ruas de um número expressivo de jovens dando voz aos direitos coletivos.

Essa desigualdade constou no discurso dos alunos, na ausência do cumprimento do direito à educação, como apontado por diversos alunos ao constatarem a falta de instituições educacionais que favoreçam a especialização dos indivíduos. Temos assim, a reivindicação de educação como um direito fundamental de natureza social. Os alunos reconheceram a estreita ligação da educação com uma vida digna, com os direitos fundamentais e com a dignidade do homem. Nesse momento vem à memória, também, o texto de Paulo Freire (1995) quando afirma que:

Antes de tornar-me um cidadão do mundo, fui e sou um cidadão do Recife, a que cheguei a partir do meu quintal, no bairro da Casa Amarela. Quanto mais enraizado na minha localidade, tanto mais possibilidades tenho de me espraiar, me mundializar. Ninguém se torna local a partir do universal (FREIRE, 1995, p. 25).

O entendimento é que o processo de construção do conhecimento e de formação da cidadania parte de temas relacionados ao contexto do educando e da sua compreensão inicial do mundo. Nesse sentido, como afirma Freire (1995), conhecer é apreender o mundo a partir da dialogicidade, em que a realidade imediata vai sendo inserida em totalidades mais 
abrangentes, revelando que a realidade local, existencial, possui relações com outras dimensões: regionais, nacionais, continentais, planetárias e em diversas perspectivas sociais, política, econômica que se interpenetram.

Observou-se nas narrativas dos alunos que os projetos e sonhos individuais são também coletivos, fato que demonstraram que a linha entre o direito coletivo e o individual é extremamente tênue, misturando-se e se tornando inseparáveis.

A maioria dos alunos teve como sustentáculo a família e os amigos. A religião também estava presente como base de apoio para diversos alunos. Esses dados revelaram a importância do tema entre os jovens, onde os amigos e a família possuem um papel de apoio muito significativo.

A família representa a matriz da aprendizagem humana, com significados e práticas culturais próprias que geram modelos de relação interpessoal e de construção individual e coletiva; é a matriz do desenvolvimento psicossocial de seus membros, já que é no convívio doméstico que se vinculam os primeiros passos de uma educação moral e de valores, de exemplos de convivência social, e de amizade na relação com outros indivíduos. Entretanto, atualmente ocorre na família uma reinvenção onde a mulher e o homem assumem novos papéis e novos desafios. Segundo Libânio (2004), a família apesar de toda a fragilidade, é ainda um dos lugares privilegiados de socialização do jovem, onde se cria relações estáveis, afetivas consistentes.

O que se evidenciou nas narrativas visuais implícitas no tema abordado "Lugares de sonhar: perspectivas futuras" nas duas escolas: foi que os alunos se posicionaram segundo as visualidades difundidas pelos meios das tecnologias de informação e comunicação, que representam e justificam o mundo social, pois geram formas simbólicas que reproduzem modos de vida e definem relações entre grupos e classes sociais.

Nesse enredamento social as imagens têm uma função fundamental na definição de nosso estar no mundo, como evidencia Raimundo Martins ao afirmar que "eu não escolho nascer homem ou mulher, não escolho nascer em uma família católica de classe média, não escolho frequentar determinados ambientes. Quando me dou conta, já estou em um determinado núcleo familiar, frequentando determinados espaços" (Entrevista Raimundo Martins - Salto para o Futuro). Para o autor, essas vivências vão compondo o modo de ver e viver no mundo. 


\section{CONSIDERAÇÕES FINAIS}

O remate do trabalho exigiu respostas resultantes da produção da pesquisa narrativa visual dos alunos da educação de Jovens e Adultos na perspectiva da cultura visual: qual a finalidade da pesquisa? Como foi desenvolvido o trabalho? E, quais resultados alcançados?

A pesquisa teve como objetivos: apreender a narrativa visual dos alunos de EJA na sua relação com o espaço urbano; refletir como eles veem a cidade onde vivem e compreender como as visualidades do cotidiano afetam a leitura do mundo e como a leitura influencia sua experiência de vida.

Após a conclusão da prática pedagógica que resultou na apreensão das narrativas visuais produzidas pelos alunos das duas escolas pesquisadas, a primeira percepção gerou inquietações uma vez que nelas estavam expressas imagens das cidades onde vivem, de forma clara e objetiva os alunos projetaram as diferenças ambientais entre as Regiões Administrativas do Distrito Federal. Essas mesmas imagens foi observada nos percursos para as escolas, onde os alunos deixaram vislumbrar em suas narrativas os aspectos dessa realidade observada pela pesquisadora.

Durante a construção do texto, as narrativas visuais e os alunos da Educação de Jovens e Adultos se constituíram nos principais recursos investigativos para o desenvolvimento da pesquisa. Respaldada teoricamente na cultura visual enquanto campo interdisciplinar, que propõe um estudo não somente das imagens e seus usos, mas como essas imagens e usos são construídos por meio das relações sociais e históricas; ao mesmo tempo, como essas relações constroem as maneiras de visualizar e usar as imagens.

No contato com os alunos a intenção foi instigar os lugares e lembranças da infância, da cidade, e do futuro no cotidiano do espaço urbano onde vivem, sob a ótica da cultura visual, o que possibilitou desestabilizar as normas que permeiam o ensino da Arte descontextualizado do uso das visualidades cotidianas e da experiência de vida dos alunos, contrapondo dessa forma, que as imagens produzidas pelos alunos oferecem discursividade e constroem novos conhecimentos sobre os efeitos dessas visualidades.

Dessa forma, os conhecimentos construídos por meio das narrativas visuais produzidas pelos alunos sinalizaram para novas possibilidades de estratégias pedagógicas, no processo de ensino e aprendizagem de Arte para a modalidade de ensino de EJA, uma vez que as imagens cotidianas informam significados que orientam maneiras de perceber, estar e dialogar com o mundo imagético. 
Nessa perspectiva, os estudos da cultura visual coincidem com a mudança no conceito de arte, fazendo com que os expectadores se tornem também, intérpretes e as imagens passam a ser consideradas não apenas em seus valores estéticos, mas sim nas compreensões dos seus papéis sociais em contextos sociais.

Como observa Duncum (2011), uma educação que possa abordar os efeitos sociais da proliferação da imagética que satura a vida cotidiana, rompendo com a prática educacional centrada nos elementos e princípios modernistas. Nesse aspecto, a visualidade pode ser entendida como a construção cultural dos olhares que postulam que os significados sobre o mundo social são criados por meio das imagens visuais veiculadas pelos diferentes tipos de tecnologias visuais, como afirma Hernandez (2007).

A pesquisa transitou pelas diversas imagens expressas nas narrativas dos cotidianos dos alunos. As imagens produzidas constituíram o olhar de cada um e, ao mesmo tempo originaram inquietações que desestabilizaram, transformaram, emocionaram pela maneira como veem os espaços em que vivem. Algumas vezes geraram reflexões, outras vezes provocaram cegueira e preconceitos. Elas foram se tecendo e se associando a outras imagens já vistas e formando narrativas, por isso, a necessidade de entendê-las em seus contextos e perguntar: o que estas imagens geraram? O que elas nos disseram? Como nos afetaram?

Para responder às perguntas a partir das imagens das narrativas, inicialmente, compreendeu-se que se constituíam na realidade e a descrição dos fatos ocorridos. Entretanto, com a imersão no referencial teórico, as narrativas apreendidas apontaram como representações da realidade e, como tal, revelaram as mediações entre o universo social macroscópico e como este universo social foi apreendido e subjetivado pelos alunos, visto que os sujeitos estabelecem sua subjetividade por meio das interações com o espaço urbano em que vivem e com outros indivíduos.

Como referencia Lev Vigotsky (1984), o conhecimento ocorre a partir do que é sabido pelo individuo de seu cotidiano, do que ele internalizou ao longo de seu desenvolvimento, por meio das relações sociais estabelecidas, como produção Cultural. Essa mesma ideia encontra em Paulo Freire (1996), ao afirmar que o conhecimento deve ser construído partindo da necessidade reconhecida do cotidiano do sujeito em seu espaço histórico e cultural.

A partir dessa consciência, foi possível delinear discussões que passaram a ser momentos de conversas, encontros e trocas, sendo as narrativas visuais consideradas portadoras e mediadoras de posições discursivas que contribuíram para compreender e interpretar as representações das realidades dos alunos em seus espaços urbanos, suas 
diferentes experiências vividas e trajetórias de formação dos alunos da Educação de Jovens e Adultos.

Assim, a pesquisa consistiu na busca de um caminho que apontasse para entendimento de como os jovens e adultos lidaram e construíram significados em torno do mundo imagético e, em como construíram as narrativas sobre eles, os outros e sobre o espaço urbano, por meio de imagens. As ideias que afluíram com as imagens permitiram interações com outras imagens e outras ideias demonstrando que a cultura visual produz visões sobre nós mesmos, sobre os outros e sobre o mundo.

A própria identificação dos alunos pelo nome foi o reconhecimento de sua subjetividade como cidadão de sua comunidade, que assumiram a autoridade de narradores visuais de seus conhecimentos sociais a respeito de si, do seu meio e do seu futuro, já que foi perceptível a estreita relação entre o significado das narrativas visuais e o significado construído historicamente pelos meios social e cultural.

As interpretações das narrativas foram realizadas em sua grande maioria a partir de diálogos travados em sala de aula com os alunos, e outras, foram por meio de observações e leituras, todas com o suporte de diversos autores que discorreram sobre os conceitos e contextos das cidades, da EJA, e da cultura visual que subsidiaram as compreensões e interpretações das narrativas produzidas.

Nessa experiência surgiram possibilidades de extrair diversas interpretações de narrativas de um conjunto de evidências culturais que não podem ser descartadas como informações, já que elas apresentam eventos e descrevem cenários e circunstâncias sociais. Essas possibilidades geraram uma crença de que esse tipo de narrativa abre novas perspectivas de apreensão e compreensão de saberes das práticas sociais e culturais de comunidades.

Com isso, espera-se contribuir para que os alunos de Planaltina e Ceilândia, a partir de suas narrativas, contem e recontem histórias, alargando o entendimento do contexto sociocultural em que vivem, perfazendo assim, a história visual de si mesmos e de suas comunidades.

Cabe observar que esse é um processo em permanente construção em narrar e recontar histórias, no qual somos relatores de nossas vivências e existência e de como construímos nossas representações sobre nós, os outros e o meio que vivemos a partir dos objetos visuais que invadem nosso cotidiano. 


\section{REFERÊNCIAS}

ABRAMOVAY, Miriam et al. Juventude, violência e vulnerabilidade social na América Latina: desafios para políticas públicas. Brasília: UNESCO, BID, 2002.

ALVES-MAZZOTTI, A. J.; GEWANDSZNAJDER, F. O método nas ciências naturais e sociais: pesquisa quantitativa e qualitativa. São Paulo: Pioneira, 1998.

ANDRÉ, Marli. E. D. A. A pesquisa no cotidiano escolar. In: FAZENDA, I. (Org.). Metodologia da pesquisa educacional. 6. ed. São Paulo: Cortez, 2000.

ARIÈS, Philippe. História social da criança e da família. Rio de Janeiro: LTC, $2^{\mathrm{a}}$ ed., 2006.

ARROYO, Miguel. Educação de Jovens e Adultos: um campo de direitos e de responsabilidade pública. In: GIOVANETTI, Maria Amélia, GOMES, Nilma Lino e SOARES, Leôncio (orgs.). Diálogos na Educação de Jovens e Adultos. Belo Horizonte, MG: Autêntica, 2006.

ASSIS, Henrique Lima. Somos aquilo que narramos: relações entre experiência vividas e objetos que habitam as casas. In: OLIVEIRA, Marilda Oliveira de (Org.). Arte, Educação e Cultura. Santa Maria: Editora UFSM, 2015. p. 119-132.

AUGÉ, Marc. (2012). Não Lugares: introdução a uma antropologia da supermodernidade. São Paulo: Papirus, 2012.

BACHELARD, Gaston. A Poética do Espaço. In: Os Pensadores XXXVIII. 1. ed. São Paulo: Abril Cultural, 1974.

BALBINO, Anita Motta Jessica. Hip hop: a cultura marginal do povo para o povo, independente, 2006. Disponível em http://www.academia.edu/7969743/ Hip_hop_a_cultura marginal. Acesso fev. 2016.

BAUER, Martin W.; GASKELL, G. Pesquisa qualitativa com texto, imagem e som: um manual prático. Petrópolis, RJ: Vozes, 2002.

BAUMAN, Zygmunt. Modernidade Líquida. Rio de Janeiro: Jorge Zahar Editor, 2001.

BAUMAN, Zygmunt. Vida para Consumo: a transformação das pessoas em mercadoria. Tradução de Carlos Alberto Medeiros. Rio de Janeiro: Jorge Zahar, 2008.

BEISIEGEL, Celso de Rui. Considerações sobre a política da União para a educação de jovens e adultos analfabetos. Revista Brasileira de Educação, São Paulo, Jan./Abr. 1999, nº 4, p. 26-34.

BEISIEGEL, Celso de Rui. Estado e educação popular: um estudo sobre a educação de adultos. Brasília: Líber Livro, 2004.

BENJAMIN, Walter. Obras escolhidas. Magia e técnica, arte e política (7a ed.). São Paulo: Brasiliense, 1994.

BENJAMIN, Walter. Paris do Segundo Império. In: Charles Baudelaire: um lírico no auge do capitalismo. Obras escolhidas III. São Paulo: Brasiliense, 2000.

BENJAMIN, Walter. Reflexões sobre a criança, o brinquedo e a educação. São Paulo: Livraria Duas Cidades, 2014.

BERTRAN, Paulo. História da Terra e do Homem no Planalto Central: Eco-história do Distrito Federal: do indígena ao colonizador. Brasília: Solo Editores, 1994. 
BOGDAN, Robert C.; BIKLEN, Sari Knopp. Investigação qualitativa em educação: uma introdução à teoria e aos métodos. Porto: Porto Editora, 1982.

BOURDIEU, Pierre. Sociologia. São Paulo: Ática, 1983.

BOURDIEU, Pierre. A economia das trocas simbólicas. São Paulo: Perspectiva, 2007.

BOURRIAUD, Nicolas. Estética Relacional. São Paulo: Martins, 2009.

BRANDÃO. Carlos. Planejamento Territorial no Brasil: provisão de bens e serviços públicos e coletivos nos espaços urbanos e regionais. Revista eletrônica e-metropolis, edição $n^{\circ} 23$. 2015. Disponível em http://observatoriodasmetropoles.net/index.php? option=com_k2

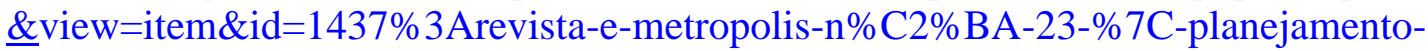
territorial-no-brasil\&Itemid=181. Acesso fev. 2016.

BRASIL. Documentário, 2012, 52 min. - Direção: Pedro Arantes. Disponível em http://www2.camara.leg.br/camaranoticias/tv/materias/DOCUMENTARIOS/429921-O-

RISO-DOS-OUTROS-(DIRECAO-PEDRO-ARANTES) e/ou www.youtube.com/watch? v=LTxtEZGp58g. Acesso mar. 2016.

BRENELLI, Rosely P. O jogo como espaço para pensar: A construção de noções lógicas e aritméticas. Campinas, SP: Papirus, 1996.

CABRAL, Alvaro. Dicionário de Psicologia e Psicanálise (2a ed.). Rio de Janeiro: Expressão e Cultura, 1979.

CANCLINI, Néstor García. Culturas híbridas: estratégias para entrar e sair da modernidade. 2.ed. São Paulo: Edusp, 1998.

CARDONETTI, Vivien Kelling; OLIVEIRA, Marilda de Oliveira. Diário de aula: disparador de problematizações e de possibilidades para pensar a formação de professores de Artes Visuais. In OLIVEIRA, Marilda de Oliveira, HERNÁNDEZ, Fernando (orgs.) A formação do professor e o ensino de Artes Visuais. Santa Maria: Editora da UFSM, 2015. p. 51-73.

CARLOS, Ana Fani Alessandri. A condição espacial. São Paulo: Contexto, 2011.

CARVALHO, José Jorge de. "O jogo das bolinhas de vidro: uma simbólica da masculinidade”. In: Anuário Antropológico 87. Brasília, UnB/Tempo Brasileiro, 1990.

CASTRO, Mary Garcia; ABROMOVAY, Miriam. Jovens em situação de pobreza, vulnerabilidades sociais e violências. Cadernos de Pesquisa, $n^{\circ}$ 116. São Paulo jul.2002. Disponível em $\quad$ http://www.scielo.br/scielo.php?script=sci_arttext\&pid=S010015742002000200007. Acesso fev. 2016.

CENTRO DE ENSINO MÉDIO 03 CEILÂNDIA. Projeto Político Pedagógico (mimeografado).

CERATTI, M. R. N. Evasão escolar: causas e consequências. 2008. Disponível em www.diaadiaeducacao.pr.gov.br/portals/pde/arquivos/242-4.pdf? Acesso jul. 2016.

CERTEAU, Michel. A invenção do cotidiano: artes de fazer. Petrópolis, Vozes, 2002.

CERTEAU, Michel. A cultura no plural. Campinas, SP, Papirus, 2012.

CHAUÍ, Marilena. Brasil: Mito fundador e sociedade autoritária. São Paulo, Perseu Abramo, 2000.

CHARRÉU, Leonardo. "Imagen global e Cultura Visual: Sobre o que se pode aprender no espaço mediático próximo/ Global Image and Visual Culture: On what we can learn from the mediatic space" (Coords) Vítor Trindade, Maria de Nazaret Trindade e Adelinda Candeias. 
Actas do Congresso Internacional The Unicity of Knowledge”. Évora: CIEP - Centro de Investigação em Educação e Psicologia da Universidade de Évora, 2007. p. 192.

CLANDININ, D. Jean; CONNELLY, F. Michael. Pesquisa Narrativa: experiência e história em pesquisa qualitativa, Uberlândia: EDUFU, 2011.

COSTA, Graciete Guerra. As Regiões Administrativas do Distrito Federal de 1960 a 2011. Tese doutorado. Faculdade de Arquitetura e Urbanismo. Brasília: UnB, 2011.

CRUZ, Michelle Brugnera. Bonecas, diversidade e inclusão: brincando com as diferenças. Revista Psicopedagogia. Vol. 28, $\mathrm{n}^{\mathrm{o}}$ 85. São Paulo, 2011. Disponível em http://pepsic.bvsalud.org/scielo.php?pid=S0103-84862011000100005\&script=sciarttext. Acesso jan. 2016.

CUNHA, Maria Isabel da. Conta-me agora! As narrativas como alternativas pedagógicas na pesquisa e no ensino. Rev. Fac. Educ., São Paulo, v. 23, n. 1- 2, jan. 1997. Disponível em: http://www.scielo.br/scielo.php?script=sci_arttext\&pid=S0102-25551997000100010. Acesso dez. 2015.

CUNHA, Susana Rangel Vieira da. Cor, som e movimento: A expressão plástica, musical e dramática no cotidiano da criança. Revista Projeto: Artes Plásticas, v. 3 n. 5, 2001.

CUNHA, Susana Rangel Vieira da. Cultura visual e Infância. Universidade Federal do Rio Grande do Sul: Faculdade de Educação. Tese de Doutorado. 2005.

CUNHA, Susana Rangel Vieira da. Imagens como pedagogias culturais em cenários da educação infantil. In MARTINS, Raimundo; TOURINHO, Irene (orgs.). Pedagogias Culturais. Santa Maria: Editora da UFSM, 2014. p. 199-223.

CUNHA, Virgínia Perini Peralta. Cotidiano, imagem e experiência - uma narrativa escolar contemporânea. Universidade Federal de Goiás: Faculdade de Artes Visuais. Dissertação de Mestrado, 2013.

DAMATTA, Roberto. et al. Universo do futebol. Rio de Janeiro: Pinakotheke, 1982.

DAMO, Arlei Sander. Monopólio estético e diversidade configuracional no futebol brasileiro. Movimento, Porto Alegre, v. 9, n. 2, p. 129-156, maio/ago., 2003.

DEL PRIORI Marly Lucy M. (Org.) História das Crianças no Brasil. São Paulo: Contexto, 1999.

DESLANDES, Suely. F. A construção do projeto de pesquisa. In: MINAYO, M. C. S. (Org.). Pesquisa social, teoria, método e criatividade. Petrópolis: Vozes, 1994.

DIAS, Belidson. O i/mundo da educação da cultura visual. Brasília: Editora da pósgraduação em arte da Universidade de Brasília, 2011.

DIAS, Belidson. Pré-acoitamentos os locais da arte/educação e da Cultura Visual. In MARTINS, Raimundo (org.). Visualidade e educação. Goiânia: FUNAPE, 2008. p. 37-53.

DINIZ, Maria Helena. Curso de direito civil brasileiro. 17. ed. São Paulo: Saraiva, 2002.

DUNCUM, Paul. Por que a arte-educação precisa mudar e o que podemos fazer. In MARTINS, Raimundo; TOURINHO, Irene (orgs.). Educação da Cultura Visual: conceitos e contextos. Santa Maria: Editora UFSM, 2011. p. 15-30.

ELIAS, Norbert \& DUNNING, Eric. A busca da excitação. Trad. de M. M. A. Silva. Lisboa: DIFEL, 1992. 
FERNANDES, Florestan. A integração do negro na sociedade de classes. Volume I. $3^{\text {a }}$ Ed. São Paulo: Ática, 1978.

FORTUNATO Ivan. Educação de jovens e adultos. Revista de Estudos Universitários. Sorocaba: São Paulo, v. 36, n. 3. 2010. p. 281-283.

FREIRE, Paulo. Educação Como Prática de Liberdade, $2^{a}$. ed. Rio de Janeiro: Paz e Terra, 1969/1992/1996/1999.

FREIRE, Paulo. Pedagogia do Oprimido. 11ª ed. Rio der Janeiro: Paz e Terra, 1982.

FREIRE, Paulo. Educação e Mudança 10a . ed. Tradução de Moacir Gadotti e Lílian Lopes Martins. Rio de Janeiro. Paz e Terra, 1982a.

FREIRE, Paulo. À sombra desta mangueira. São Paulo: Olhos d’Água, 1995.

GENTILI, Pablo. A exclusão e a escola: o apartheid educacional como política de ocultação. In. ALENCAR, Chico; GENTILI, Pablo. Educar na esperança em tempos de desencanto. Petrópolis-RJ: Vozes, 2001. p. 25-43.

GONÇALVES, Eduardo. A Casa Edison e a formação do mercado fonográfico no Rio de Janeiro no final do século XIX e início do século XX. Desigualdade \& Diversidade Revista de Ciências Sociais da PUC-Rio, $\mathrm{n}^{\mathbf{o}}$ 9, ago/dez, 2011. Disponível em http://desigualdadediversidade.soc.puc-rio.br/media/10\%20DeD\%20_\%20n.\%209\%20\%20artigo\%205\%20-\%20EDUARDO.pdf. Acesso fev. 2016.

HADDAD, Sérgio. Estado e educação de adultos (1964/1985). Tese de Doutorado. Faculdade de Educação da Universidade de São Paulo, 1991.

HADDAD, Sérgio. Em Aberto, Brasília, ano 11, n 56, out./dez. 1992.

HADDAD, Sérgio; DI PIERRO, Maria Clara. Escolarização de jovens e adultos. Revista Brasileira de Educação. Rio de Janeiro. v. 14, maio/ago. 2000. p. 108- 130.

HADDAD, Sérgio. Ação dos governos locais na educação de jovens e adultos. Revista Brasileira de Educação. Rio de Janeiro, v. 12, maio/agosto, 2007. p. 197-211.

HERNÁNDEZ, Fernando H. Transgressão e Mudança na Educação: os projetos de trabalho. Porto Alegre: Artmed, 1998.

HERNÁNDEZ, Fernando H. Cultura Visual, Mudança Educativa e Projeto de Trabalho. Porto Alegre: Artmed, 2000.

HERNÁNDEZ, Fernando H. Catadores da Cultura Visual: transformando fragmentos em nova narrativa educacional. Porto Alegre: Mediação, 2007.

HERNÁNDEZ, Fernando H.SANCHO, María Juana; RIVAS, José Ignacio (coords.). Historias de Vida em Educación: Biografias em contexto. ESBRINA - RECERCA Universitat de Barcelona, 2011. Disponível em http://diposit.ub.edu/dspace/bitstream /2445/15323/7/Historias\%20de\%20vida\%20en\%20Educaci\%C3\%B3n.\%20Biografias\%20en $\% 20$ contexto.pdf. Acesso nov/2015.

HERNÁNDEZ, Fernando H. A construção da subjetividade docente como base para uma proposta de formação inicial de professores de Artes Visuais. In: OLIVEIRA, Marilda de Oliveira, HHERNÁNDEZ, Fernando H. (orgs.). A formação do professor e o ensino das artes visuais. Santa Maria: Editora UFSM, 2015. p. 15-36.

HOLSTON, James. A Capital Modernista: uma crítica de Brasília e sua utopia. (trad. Marcelo Coelho). São Paulo, Companhia das Letras, 1993. 
HORN, Ticiana Elisabete. "É qui eu num sei nada di nada!" Visualidade sobre a infância rural em artefato visuais endereçados às crianças. In: MARTINS, Raimundo; TOURINHO, Irene (orgs.) Cultura visual e infância: quando as imagens invadem a escola. Santa Maria: Editora UFSM, 2010. p. 191-208.

JOFFILY, Geraldo I. Brasília e sua ideologia. Brasília: Thesaurus Editora, 1977.

JORGE, Maria Helena P. de Mello; LATORRE, Maria Rosário D. O. Acidentes de trânsito no Brasil: dados e tendências. Cadernos de Saúde Pública, vol. 10 sup. 1 Rio de Janeiro, 1994. Disponível em $\quad$ http://www.scielo.br/scielo.php?pid=S0102-311X1994000500003 \&script=sci_arttext. Acesso fev. 2016.

JOSSO, Marie-Chistine. Experiências de vida e formação. São Paulo: Editora Cortez, São Paulo 2004. P. 40-41.

JOSSO, Marie-Christine. A transformação de si a partir da narração de histórias de vida. Educação: Porto Alegre/RS, ano XXX, n. 3 (63), set./dez. 2007. p. 413-438.

JOSSO, Marie-Christine. Caminhar para Si. Porto Alegre: EDIPUCRS, 2010.

JOSSO, Marie-Christine. O corpo biográfico: corpo falado e corpo que fala. Educ. Real. Porto Alegre, v. 37, n. 1, jan./abr. 2012. p. 19-31. Disponível em: http://www.ufrgs.br/edu realidade/. Acesso mar. 2016.

KISHIMOTO, Tizuko. M. Jogos Infantis: o jogo, a criança e a educação. Petrópolis, Rio de Janeiro: Vozes, $12^{\mathrm{a}}$ ed., 1993.

LAKATOS, Eva M.; MARCONI, Marina A. Fundamentos da metodologia científica. 5 ed. rev. ampl. São Paulo: Atlas, 2003.

LAMPERT, Jociele. O ensino da arte em espaços silenciosos da cultura visual. In: OLIVEIRA, Marilda Oliveira de (Org.). Arte, Educação e Cultura. Santa Maria: Editora UFSM, 2015. p. 247-268.

LAVILLE, Christian. DIONNE, Jean. A construção do saber: manual de metodologia da pesquisa em ciências humanas. Porto Alegre: Artimed; Belo Horizonte: Editora UFMG, 1999.

LECCUR/UFPB. Laboratório de Estudos sobre Cidades, Culturas Contemporâneas e Urbanidades. Fotografando a experiência na cidade. Revista Eletrônica e-metropolis, $\mathrm{n}^{\mathbf{o}} 21$, ano 6. Junho de 2015. Disponível em http://emetropolis.net/system/edicoes/arquivo pdfs/000/000/021/original/emetropolis_n21.pdf?1447896387. Acesso fev. 2016.

LIBANIO, João B. Jovens em tempo de pós-modernidade: considerações socioculturais e pastorais. São Paulo: Loyola, 2004.

LOURO, Guacira Lopes. O corpo educado: pedagogias da sexualidade. Belo Horizonte: Autêntica, 1999.

LÜDKE, Menga; ANDRÉ, Marli. E. D. A. Pesquisa em educação: abordagens qualitativas. São Paulo: EPU, 2012.

LYNCH, Kevin. A imagem da cidade. São Paulo: Martins Fontes, 1999.

MARQUES, L. P.; OLIVEIRA, S. P. P. Paulo Freire e Vigotsky: reflexões sobre a educação. In: Colóquio Internacional Paulo Freire. Memórias dos Colóquios on-line. Recife: [s.n.], 2005. Disponível em: http://www.paulofreire.org.br/pdf/comunicacoes orais/. Acesso dez. 2015.

MARTINS, Raimundo. Cultura Visual: imagem, subjetividade e cotidiano. In: MEDEIROS, Maria Beatriz. (org.). Arte em Pesquisa: Especificidades Ensino e Aprendizagem da Arte 
Linguagens Visuais. V. 2. Brasília: Editora da Pós-Graduação em Arte da Universidade de Brasília, 2004. p. 160-166.

MARTINS, Raimundo. Educar com imagens: múltiplos tempos de interpretação. Artigo publicado no Boletim Arte na Escola $\mathrm{n}^{\circ}$ 45, Abril de 2007. Disponível em: http://artenaescola.org.br/sala-de-leitura/artigos/artigo.php?id=69370. Acesso jul/2016.

MARTINS, Raimundo. Das belas artes à cultura visual: enfoques e deslocamentos. In: MARTINS, Raimundo. (org.). Visualidade e educação. Goiânia: FUNAPE, 2008. p. 25-35.

MARTINS, Raimundo; TOURINHO, Irene. Pesquisa narrativa: concepções, práticas e indagações. In: Anais do II Congresso de Educação, Arte e Cultura - CEAC. Santa Maria: 2009.

MARTINS, Raimundo. Narrativas Visuais: Imagens, Visualidades e Experiência Educativa. VIS - Revista do Programa de Pós-Graduação em Arte. Brasília: Editora Brasil, v. 8 n ${ }^{\circ}$ 1, janeiro/junho de 2009. p 33-39.

MARTINS, Raimundo. Visão, visual e visualidade. In: GUIMARÃES, Leda M. de B. (Orgs.). Trama 3. Faculdade de Artes Visuais. Goiânia: FUNAPE, 2010, p. 146-151.

MARTINS, Raimundo; MARTINS, Alice Fátima. Mesclando diferenças a partir de narrativas abertas sobre estudos de cultura visual e ensino de arte. In: MARTINS, Raimundo; MARTINS, Alice Fátima (orgs.). Cultura Visual e ensino de arte: concepções e práticas em diálogo. Pelotas: Ed. UFPel, 2014. p. 7-13.

MARTINS, Raimundo. Deslocamentos perceptivos e conceituais da cultura visual: implicações para a formação de professores. In OLIVEIRA, Marilda de Oliveira; HERNÁNDEZ, Fernando. (orgs.). A formação do professor e o ensino das Artes Visuais. Santa Maria: Editora da UFSM, 2015. p. 89-102.

MARTINS, Raimundo. A cultura visual e a construção social da arte, imagem e das práticas do ver. In: OLIVEIRA, Marilda Oliveira de (Org.). Arte, Educação e Cultura. Santa Maria: Editora UFSM, 2015. p. 17-38.

MENEZES, Luciano Osmar; TREVISOL, Maria Teresa Ceron. Adolescentes e projetos de vida: um estudo com alunos do $1^{\circ}$ ano do Ensino Médio. Revista Leleopoldianum de estudos e comunicações da Universisda Católica de Santos, ano 40, no 110/111/112. Universidade do Oeste de Santa Catarina - UNOESC, 2014. p. 13-24.

MINAYO, Maria Cecília de Souza. (org.). Pesquisa social: teoria, método e criatividade. Petrópolis: Vozes, 1994.

MINAYO, Maria Cecília de Souza. O desafio do conhecimento: pesquisa qualitativa em saúde. São Paulo: Hucitec; Rio de Janeiro: Abrasco, 2000.

MINISTÉRIO DA EDUCAÇÃO. Instituto Nacional de Estudos e Pesquisas Educacionais Anísio Teixeira Censo da educação básica: 2011. Brasília: Instituto Nacional de Estudos e Pesquisas Educacionais Anísio Teixeira, 2012.

MIRANDA, Fernando. Pedagogias das imagens: de artes visuais e shopping centers. In: MARTINS, Raimundo; TOURINHO, Irene. Pedagogias culturais. Santa Maria: Editora UFSM, 2014. p. 293-313.

MOISÉS, José Álvaro. Os Brasileiros e a Democracia: bases sócio-políticas da legitimidade democrática. São Paulo: Ática, 1995. 
MOISÉS, José Álvaro. A desconfiança das instituições democráticas. Opinião Pública, vol.11, nº1, 2005. p. 33-63.

MORA, José. F. Dicionário de Filosofia. São Paulo: Martins Fontes, 1998.

MOREIRA, Daniele Aparecida Fruchi. A brincadeira de amarelinha na Educação Infantil: uma contribuição para o desenvolvimento de habilidades matemáticas, em crianças de 4 anos. Lins, São Paulo, 2013. Disponível http://www.unisalesiano.edu.br/biblioteca/monografias/56007.pdf. Acesso fev. 2016.

MOREIRA, Daniel Augusto. O método fenomenológico na pesquisa. São Paulo: Pioneira Thomson, 2002.

MOURA, Tânia Maria de. Alfabetização de Adultos. Freire, Ferreiro, Vigotsky. Contribuições teórico-metodológicas à formulação de propostas pedagógicas. Tese de Doutorado. PUC/SP, 1998.

NASCIMENTO, Erinaldo Alves. Visualidade e infância até os seis anos: versões em imagens e os desafios da educação infantil. In: MARTINS, Raimundo; TOURINHO, Irene (orgs.) Cultura visual e infância: quando as imagens invadem a escola. Santa Maria: Editora UFSM, 2010. p. 15-36.

NASCIMENTO, Erinaldo Alves. Singularidades da educação da cultura visual nos deslocamentos das imagens e das interpretações. In: MARTINS, Raimundo; TOURINHO, Irene (Org.). Educação da cultura visual: conceitos e contextos. Santa Maria: Editora UFSM, 2011. P. 209-226.

NASCIMENTO, Erinaldo Alves. A cultura Visual no Ensino de Arte Contemporânea: singularidades no trabalho com as imagens. Disponível em http://www.artenaescola.org.br. Acesso mar. 2016.

NOVACAP. Revista Brasília, Ano I, no 3 março/1957. Disponível no acervo digital do Senado Federal.

NUNES, Luciana Borre. A cultura visual nas tramas escolares: a produção da feminilidade nas salas de aula. In: MARTINS, Raimundo; TOURINHO, Irene (orgs.). Cultura Visual e infância: quando as imagens invadem a escola. Santa Maria : Editora UFSM, 2010. p. 165189.

NUNES, Luciana Borre; MARTINS, Raimundo. Um convite para "educar"/pensar infância líquidas. In: MARTINS, Raimundo; MARTINS, Alice Fátima (orgs.). Cultura Visual e ensino de arte: concepções e práticas em diálogo. Pelotas: Ed. UFPel, 2014. p. 169-188.

OLIVEIRA, Ederson Gomes. Patrimônio Histórico e Cultural de Planaltina (DF): Memória e Identidade Social. Dissertação Departamento de História, Geografia e Ciências Sociais. Goiânia: Pontifícia Universidade Católica de Goiás, 2013.

OLIVEIRA, Isabel Cristina Vasconcelos de; SALDANHA, Ana Alayde Werba. Estudo comparativo sobre a perspectiva de futuro dos estudantes de escolas públicas e privadas. Paidéia (Ribeirão Preto) vol. 20, $\mathrm{n}^{\circ}$ 45. Ribeirão Preto jan./abr. 2010. Disponível em http://www.scielo.br/scielo.php?pid=S0103-863X2010000100007\&script=sci_arttext. Acesso dez. 2015.

OLIVEIRA, Maria Cláudia Santos Lopes; PINTO, Raquel Gomes; SOUZA, Alessandra da Silva. Perspectivas de futuro entre adolescentes: universidade, trabalho e relacionamentos na transição para a vida adulta. Temas psicol. Vol. 11 n $^{\circ} 1$ Ribeirão Preto jun. 2013. Disponível 
em http://pepsic.bvsalud.org/scielo.php?pid=S1413-389X2003000100003\&scriptsci arttext. Acesso jan. 2016.

OLIVEIRA, Rômulo Andrade. Brasília e o paradigma modernista: planejamento urbano do moderno atraso. Dissertação de Mestrado, Faculdade de Arquitetura e Urbanismo. São Paulo: USP, 2008.

OLIVEIRA, Vilmar Pereira de. A influência do gosto musical no processo de construção da identidade na juventude. PUC de Minas Gerais, 2012. Disponível em http://www.psicologia.pt/artigos/textos/A0661.pdf. Acesso fev. 2016.

ORICO, Osvaldo. "Armas secretas como cidade". Revista Brasília, no 32, ano 3, agosto de 1959, p. 8.

PACIEVITCH, T. Evasão escolar. 2010. Disponível em: http://www.infoescola.com/ educacao/evasao-escolar/. Acesso jul. 2016.

PAIVA, Vanilda Pereira, MOBRAL: um desacerto autoritário I, IIe III. Rio de Janeiro: Síntese, Ibrades, n. 23-24, 1982.

PAVIANI, Aldo (org.). Periferização Urbana. Brasília: Editora da Universidade de Brasília, 1987.

PAVIANI, Aldo (org.). A Conquista da Cidade: movimentos populares em Brasília. Brasília, Editora da UnB, 1991;1998.

PAVIANI, Aldo (org.). Demandas sociais e ocupação do espaço urbano. O caso de Brasília, DF. Cadernos Metrópole, $n^{\circ}$ 21, 2009.

PEARCE, Diane. The feminization of poverty: women, work and welfare. Urban and Social Change Review, 1978, p. 28-36.

PERREAULT, Jean-Phillipe. Pensar a religião entre os jovens e pensar a juventude a partir da religião. In: CASTRO, Lucia Rabello; CORREA, Jane (orgs.). Juventude Contemporânea: Perspectivas nacionais e internacionais. I ed. Rio de Janeiro, 2005.

PEREIRA, Alexandre Adalberto. Estereótipos desenhados, identidades projetadas. In: MARTINS, Raimundo; TOURINHO, Irene (orgs.). Cultura Visual e infância: quando as imagens invadem a escola. Santa Maria : Editora UFSM, 2010. p. 209-226.

PEREIRA, Alexandre Adalberto; MARTINS, Raimundo. Cultura Visual e Identidade (s) no desenho pedagógico. 16 $^{\circ}$ Encontro Nacional da Associação Nacional de Pesquisadores de Artes Plásticas - ANPAP. Florianópolis, 2007. Disponível em http://anpap.org.br/anais/2007/2007/artigos/061.pdf. Acesso jun. 2016.

PETRONIA, Ana Paula; SOUZA, Vera Lúcia Trevisan. Vigotski e Paulo Freire: contribuições para a autonomia do professor. Rev. Diálogo Educ., Curitiba, v. 9, n. 27, maio/ago, 2009. p. 351-361.

PONTES, Fernando A. Ramos; MAGALHÃES, Celina. M. Colino. A transmissão da cultura da brincadeira: Algumas possibilidades de investigação. Psicologia: Reflexão e Crítica, UFRG, Porto Alegre, v. 16, n. 1, 2003. p. 117-124.

POSSENTI, Sírio. Os Humores da Língua: Análise Linguística de Piadas. São Paulo-SP: Mercado das Letras, 1998.

RAMOS, Maria das Graças Moreira. O Intestino da Cidade. Revista Cultura Visual: Salvador, $\mathrm{N}^{\mathrm{o}}$ 11, novembro/2008. Disponível em http://www.portalseer.ufba.br/ index.php/rcvisual/ article/view/3369/2462. Acesso jun. 2016. 
RIBEIRO, Gustavo Lins. "Arqueologia de uma cidade: Brasília e suas cidades satélites". Espaço \& Debates, no 5, ano 2, abril, 1982.

RIBEIRO, Vera Maria Masagão (coord.). Educação de Jovens e Adultos: proposta curricular para o $1^{\circ}$ segmento do ensino fundamental. São Paulo: Ação Educativa Assessoria, Pesquisa, Informação; Brasília: Ministério da Educação e do Desporto, 1997. http://www.scielo.br/pdf/ccedes/v21n55/5541.pdf. Acesso dez. 2015.

RIBEIRO, Vera Maria Masagão; CATELLI, Roberto Jr.; HADDAD, Sérgio. (org.) Avaliação da EJA no Brasil: insumos, processos, resultados. Brasília : Instituto Nacional de Estudos e Pesquisa Educacionais Anísio Teixeira. 2015.

RODRIGUES, Maria Fernanda de Carvalho Carrapiço Correia. Portfolio: Estratégia Formativa e de Reflexão na Formação Inicial em Educação de Infância. Dissertação de Mestrado em Educação. Faculdade de Psicologia e Ciências da Educação, Universidade de Lisboa, 2009. Disponível em http://repositorio.ul.pt/handle/10451/2113. Acesso jul. 2015.

RODRIGUES, Luzia Maria. A criança e o brincar. Dissertação de Mestrado. Universidade Federal Rural do Rio de Janeiro: Mesquita 2009.jj

ROLNIK, Raquel. O que é cidade?. São Paulo: Brasiliense, 1988.

RUBIM, Barbara e LEITÃO, Sérgio. O plano de mobilidade urbana e o futuro das cidades. Estudos Avançados, vol. 27. $\mathrm{N}^{\circ}$ 79. São Paulo, 2013. Disponível em http://www.scielo.br/scielo.php?script=sci_arttext\&pid=S0103-40142013000300005. Acesso jan. 2016.

SANTOS, Aparecida de Fatima T. dos. Desigualdade social e dualidade escolar: conhecimento e poder em Paulo Freire e Gramsci. Petrópolis: Vozes, 2000.

SANTOS, Lucíola L. C. P. Pluraridade de saberes em processos educativos. In: CANDAU, Vera Maria. (orgs). Didática, currículo e saberes escolares. Rio de Janeiro: DP\&A, 2000.

SANTOS, Milton. Por uma Geografia Nova. São Paulo: Hucitec, Edusp, 1978.

SANTOS, Milton. Pensando o espaço do homem. São Paulo: Hucitec, 1986.

SANTOS, Milton. O espaço do cidadão. São Paulo: Nobel, 1987.

SASSO, Leísa. Livro-objeto a/r/tográfico: práticas de pedagogia cultural na periferia de Brasília. In: Dissertação de mestrado. Universidade de Brasília. Instituto de Artes, Departamento de Artes Visuais, 2014.

SECRETARIA DE ESTADO DE EDUCAÇÃO DO DISTRITO FEDERAL. Currículo em Movimento da Educação Básica: Educação de Jovens e Adultos. Brasília: GDF, 2014-2017.

SINGER, Paul. Prevenir e Curar: o controle social através dos serviços de saúde. Rio de Janeiro: Forense-Universitária. 1988.

SILVA, Carla Fernanda. Grafias da luz: a narrativa visual sobre a cidade na Revista Blumenau em Cadernos. Dissertação de Mestrado. Departamento de História: Universidade Federal de Santa Catarina, 2008.

SOBROSA, Gênesis Marimar Rodrigues et all. Perspectivas de futuro profissional para jovens provenientes de classes socioeconômicas desfavorecidas. Temas psicol. vol.22 no.1 Ribeirão Preto abr. 2014. Disponível em http://pepsic.bvsalud.org/scielo .php?pid=S1413-389X2014000100017\&script=scirttext. Acesso dez. 2015.

SZYMANSKI, Heloisa. A relação família/escola: desafios e perspectivas. Brasília, Editora Plano, 2003. 
TAVIN, Kevin M. Antecedentes críticos da cultura visual na arte educação nos Estados Unidos. In MARTINS, Raimundo (org.) Visualidade e educação. Goiânia: FUNAPE, 2008. p. 11-23.

TEIXEIRA, Evandro Camargo. Dois ensaios acerca da relação entre criminalidade e educação. Tese apresentada Departamento de Economia: USP, São Paulo, 2011.

TOURINHO, Irene. Ouvindo escolhas de alunos: nas aulas de arte eu quero aprender. In: MARTINS, Raimundo. Visualidades e Educação. Goiânia: FUNAPE, 2008. p. 71-86.

TOURINHO, Irene. Currículo para além das grades: de porões a terraços, praças e jardins. VIS - Revista da Programa de Pós-graduação em Arte. Brasília: Editora Brasil, v. $8 \mathrm{n}^{\circ} 1$. Janeiro/junho de 2009, p. 49-59.

TOURINHO, Irene; MARTINS, Raimundo. Culturas da infância e da imagem: aconteceu um fato grave, um incidente global. In: MARTINS, Raimundo; TOURINHO, Irene. (orgs.). Cultura Visual e Infância: quando as imagens invadem a escola. Santa Maria: Editora UFSM, 2010. p. 37-55.

TOURINHO, Irene; MARTINS, Raimundo. Circunstâncias e ingerências da cultura visual In: MARTINS, Raimundo; TOURINHO, Irene. (orgs.). Educação da cultura visual: conceitos e contextos. Santa Maria: Editora da UFMS, 2011. p. 51-68.

TRIVIÑOS, Augusto. N. S. Introdução à pesquisa em ciências sociais: a pesquisa qualitativa em educação. São Paulo: Atlas, 1987.

VICTORIO FILHO, Aldo. A utopia íntima da educação na cidade-tudo: cultura visual e a formação em artes visuais. In MARTINS, Raimundo e TOURINHO, Irene (orgs.) Educação da cultura visual: conceitos e contextos. Santa Maria: Editora da Universidade Federal de Santa Maria, 2011. p. 191-208.

VICTORIO FILHO, Aldo. Enfretamentos contemporâneos no ensino formal das artes: cultura visual, o corpo e a arte. $\mathbf{2 2}^{\circ}$ Encontro Nacional da Associação Nacional de Pesquisadores de Artes Plásticas-ANPAP. Belém, 2013. Disponível em www.anpap.org.br/anais/2013/ANAIS/simposio/07/Aldo\%20Victorio\%filho.pdf. Acesso em jun. 2016. p. 3206-3220.

VICTORIO FILHO, Aldo. Culturas juvenis para além dos interditos culturais: o funk carioca, potência e beleza. In: MARTINS, Raimundo e TOURINHO, Irene (orgs.). Pedagogias culturais. Santa Maria: Ed. da UFSM, 2014. p. 275-293.

VISSER, Margareth. O ritual do jantar. Rio de Janeiro: Campus, 1998.

VIGOTSKY, Lev S. A formação social da mente: o desenvolvimento dos processos psicológicos superiores. Tradução de José Cipolla Neto, Luís Silveira Menna Barreto e Solange Castro Afeche. 6. ed. São Paulo: Martins Fontes, 1984/1998.

VIGOTSKY, Lev S. A construção do pensamento e da linguagem. São Paulo: Martins Fontes, 2001.

WRIGHT, Charles. Transporte em Brasília. In: PAVIANI, A (org.). Urbanização e metropolização: A gestão dos conflitos em Brasília. EDUnB, 1987. 


\section{ANEXOS}

\section{ANEXO I - QUESTIONÁRIO PARA IDENTIFICAÇÃO DO PERFIL DO ALUNO DE EJA: PLANALTINA E CEILÂNDIA}

1. Em que Unidade da Federação você nasceu?

2. Qual a data de seu nascimento?

3. Qual o seu endereço eletrônico (e-mail)?

4.

De acordo com a categoria de cor ou raça, utilizada pelo Instituto Brasileiro de Geografia e Estatística - IBGE você se considera:
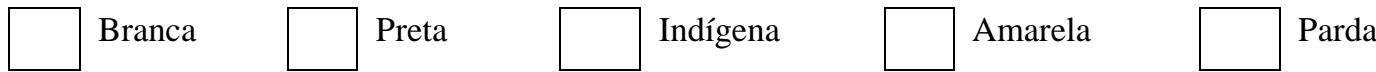

5. Situação conjugal?
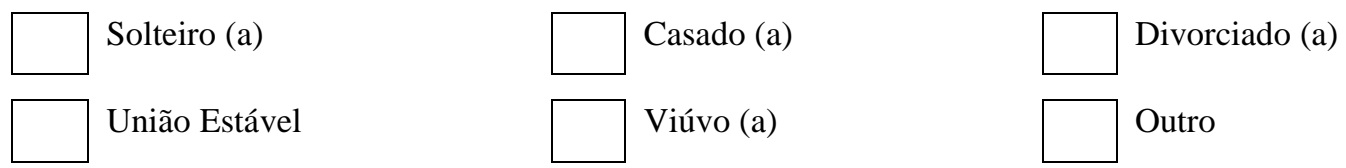

6. Voce tem filhos?

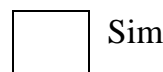

$\square$ Não Em caso afirmativo, quantos filhos:

7. Qual a sua religião?
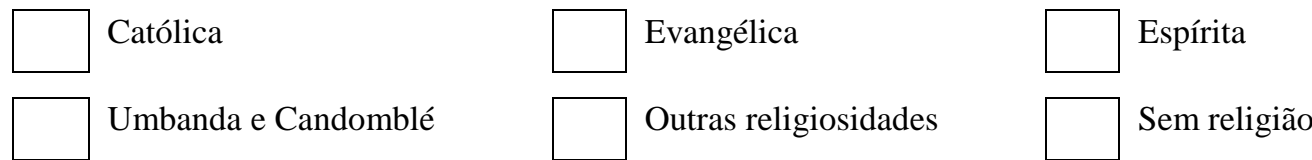

8. Na sua religião você é:
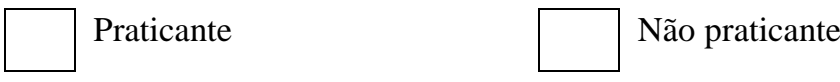

9. Qual é sua situação atual de moradia?

$\square$ Com os país

$\square$ Com o cônjuge ou companheiro(a)

Em casa de outros familiares

$\square$ Em casa de amigos

$\square$ Pensão/hotel/pensionato

Outra, qual?

10. Se você trabalha, qual(is) é(são) o(s) seu(s) turno(s) de trabalho diário?
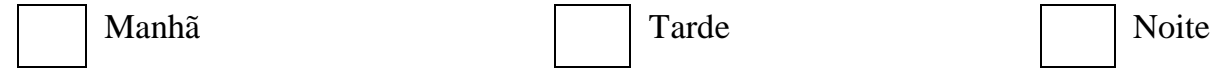

11. Na sua família quem é o chefe (pessoa que mais contribui na renda):
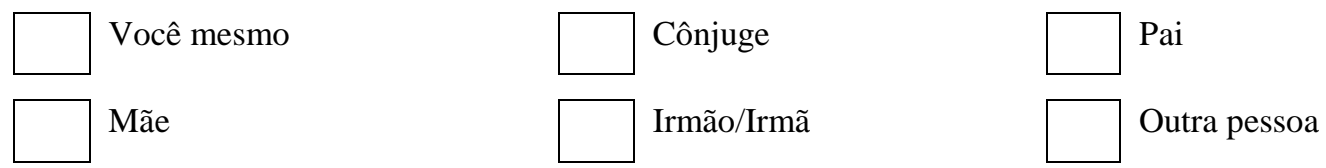

12. Qual a escolaridade do chefe de sua família:

$\square$ Analfabeto/Não estudou


$\square$ Ensino Fundamental incompleto

$\square$ Ensino Médio incompleto

$\square$ Ensino Superior Incompleto

Pós-graduação

13. Qual a escolaridade do seu pai:

$\square$ Analfabeto/Não estudou

$\square$ Ensino Fundamental incompleto

$\square$ Ensino Médio incompleto

$\square$ Ensino Superior Incompleto

$\square$ Pós-graduação

14. Qual a escolaridade de sua mãe:

\begin{tabular}{|c|}
\hline Analfabeto/Não estudou \\
\hline Ensino Fundamental incompleto \\
\hline Ensino Médio incompleto \\
\hline Ensino Superior Incompleto \\
\hline Pós-graduação \\
\hline
\end{tabular}

Ensino Médio completo

Ensino superior completo

Não sabe

Ensino Fundamental completo

Ensino Médio completo

Ensino superior completo

Não sabe

Ensino Fundamental completo

Ensino Médio completo

Ensino superior completo

Não sabe

15. Qual a sua participação na vida econômica do seu grupo familiar?

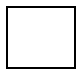

Não trabalho e sou sustentado pela família ou por outras pessoas

Trabalho, mas recebo ajuda financeira da família ou de outras pessoas

Trabalho e sou responsável apenas pelo meu próprio sustento

Trabalho, sou responsável pelo meu sustento e contribuo para o sustento da família

$\square$ Trabalho e sou o principal responsável pelo sustento da família

16. Em que tipo de escola você estudou?

$\square$ Integralmente em escola pública

Integralmente em escola particular

Maior parte em escola particular sem bolsa
Maior parte em escola pública

Em escola particular com bolsa

Em parte em escola particular com bolsa

17. Assinale o seu grau de expectativa em relação ao término do Ensino Médio, sendo:

0 - Não se aplica

2 - Alta expectativa
1 - Altíssima expectativa

3 - Indiferente 
$\square$ - Baixa expectativa

18. O que você pretende fazer após o término do Ensino Médio?
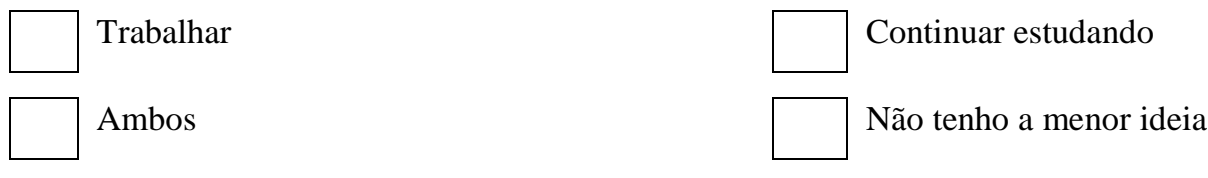

19. Se trabalhar foi uma das opções, imagina-se:

$\square$ Trabalhando exclusivamente na área de seu interesse

Trabalhando onde for possível

20. Se você optou por continuar estudando, imagina-se:

$\square$ Fazendo um Curso Profissional de nível médio

Ingressando em uma Universidade

$\square$ Fazendo uma pós-graduação em latu sensu (especialização)

Fazendo uma pós-graduação strictu sensu (mestrado/doutorado)

21. Qual a sua principal fonte de informação de acontecimentos atuais:

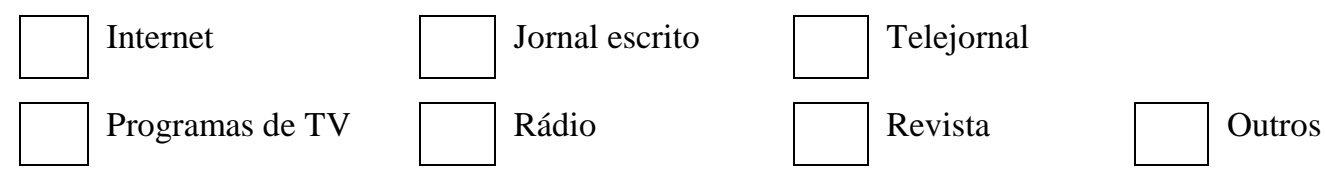

22.

Assinale o seu nível de interesse com relação aos seguintes tipos de informação. Considere zero o mínimo e cinco o máximo de interesse.
$\square$ Política

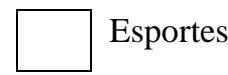
Notícias policiais
$\square$ Notícias internacionais

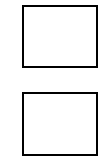
Informática

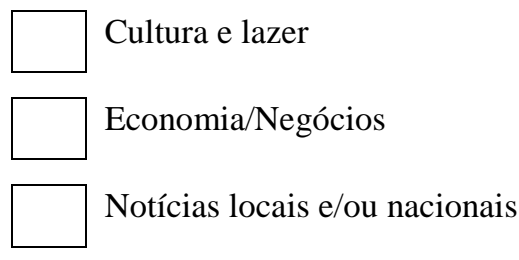

23. Com que frequência você busca essas informações?

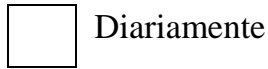

Ocasionalmente

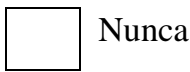

24. Excetuando livros escolares obrigatórios, que tipo de livro você lê?

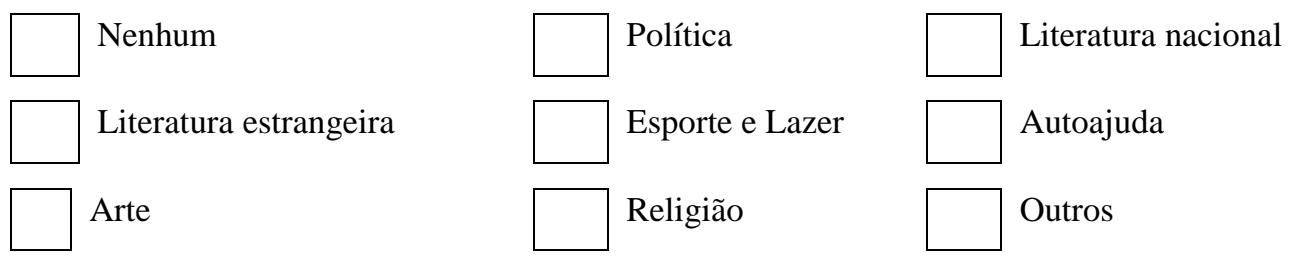

25. Quantos desses livros, aproximadamente, você lê por ano?

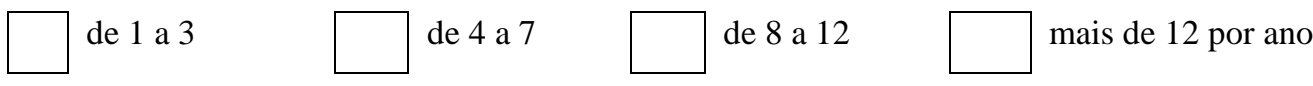

26. Com que frequência você participa das seguintes atividades? Considere os seguintes dados:

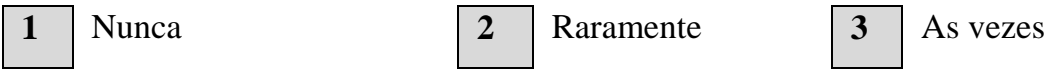


4 Frequentemente

5 Sempre

Artísticas/ Culturais/ Artesanato (coral/grupo de teatro/etc)

$\square$ Físicas e/ou Esportivas

Sociedades Científicas

Movimentos Sociais e/ou Comunitários
Político - Partidárias Movimento Estudantil

Movimentos Ecológicos

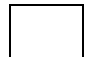

27. Com que frequência você faz as atividades abaixo, sendo:

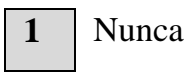

4 Frequentemente

Assistir televisão

Ir ao cinema

Jogos (baralho/bingo/vídeo game/outros)

D Dançar/ frequentar barzinhos/ encontrar amigos

28. Com relação ao domínio de microcomputador, você:

Tem muita experiência

$\square$ Tem alguma noção

\section{Raramente}

$5 \quad$ Sempre
3 As vezes

Ir ao teatro/ shows / concertos

Assistir competições esportivas

Computação (Internet/navegar/jogar)

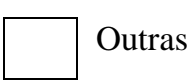

29. Com relação a línguas estrangeiras, assinale o seu nível de domínio, sendo:
1 Excelente
2 Bom
3 Regular
4 Fraco
5 Nenhum
$\square$ O seu domínio de Inglês é:
O seu domínio de Francês é:
$\square$ O seu domínio de Espanhol é:
O seu domínio de Italiano é:
$\square$ O seu domínio de Alemão é:
Outro

30. No caso de precisar de um atendimento médico, você procura preferencialmente:

$\square$ Rede Pública $\square$ Serviço Particular $\square$ Convênios tipo seguro-saúde

31. Sua última consulta médica de rotina (sem doença) ocorreu:

$\square$ No último ano

Há mais de 5 anos
Entre 1 e 5 anos

Não lembra/Nunca foi

32. Você é portador de alguma doença crônica(que necessite de tratamento constante por toda vida)

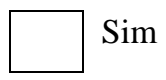

$\operatorname{Sim}$

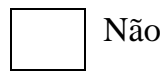

33. Você é portador de necessidade especial/deficiência?

$\square$ Visual (cego ou baixa visão)

Auditiva Física/Motora 
$\square$ Superdotado/alta habilidade

Outra (s)

34. Assinale a opção mais correta para você

— Eu só vou ao dentista se estiver com dor ou outro problema

Independente de problemas, consulto o dentista a cada 6 meses ou a cada ano

$\square$ Eu vou ao dentista esporadicamente

Eu vou ao dentista rotineiramente para tratamento especializado

Não lembra/nunca foi

35. Você já teve alguma dificuldade significativa ou crise emocional no último ano?

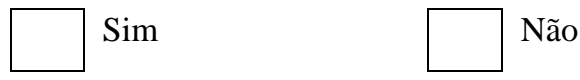

36. Você já procurou atendimento psiquiátrico em algum período de sua vida?

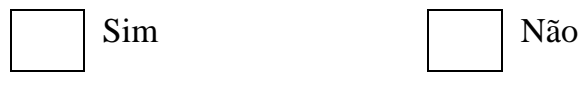

37. Assinale o grau de interferência, das dificuldades abaixo, em sua vida pessoal e/ou acadêmica, sendo:

\begin{tabular}{|c|c|c|c|c|c|}
\hline 1 & Não se aplica & 2 & Interfere muitíssimo & 3 & Interfere muito \\
\hline 4 & Interfere pouco & 5 & \multicolumn{3}{|l|}{ Não interfere } \\
\hline & \multicolumn{5}{|c|}{ Adaptação à novas situações (cidade, moradia, separar-se da família) } \\
\hline & \multicolumn{3}{|c|}{ Relacionamento social/interpessoal l(amigos ou grupos) } & & Relacionamento familiar \\
\hline & \multicolumn{3}{|c|}{ Conflitos emocionais, tais como depressão, timidez } & & Conflito de valores/conflito religioso \\
\hline & Aprendizagem & & & & Dificuldade financeira \\
\hline
\end{tabular}


ANEXO II - Plano de Trabalho/Aula - Apresentação do Projeto

TEMA:

- Apresentação do projeto para os alunos e aplicação do questionário para identificação do perfil.

\section{OBJETIVO GERAL:}

- Apresentar o projeto e coletar dados visando a identificação do perfil do aluno de EJA de Planaltina e Ceilândia.

\section{ESPECÍFICOS:}

- Especificar os objetivos do projeto de pesquisa.

- Explicar as respostas do questionário.

- Aplicar o questionário.

\section{ESTRATÉGIAS}

- Aula dialógica

- Leitura coletiva do questionário

\section{RECURSOS MIDIÁTICOS}

- Vivaldi: As quatros estações

- Projeções de fotografias das Regiões Administrativas

\section{ATIVIDADES}

- Entrega do questionário respondido 


\section{ANEXO III - Plano de Trabalho/Aula - Lugares de lembrar a infância}

\section{TEMA:}

- Lugares de lembrar a infância

\section{OBJETIVO GERAL:}

- Instigar nos alunos as memórias de infância

\section{ESPECÍFICOS:}

- Perceber as diferentes formas de perceber a infância

- Ativar a memória com música e imagens que remetem à infância

Estimular a memória infantil com as seguintes perguntas: Onde você nasceu? Quem são seus pais? Qual a história de seu nome? (quem te nomeou? porque este nome? Quais as memórias de infância que você guardou? (o que costumava fazer? Quais as brincadeiras favoritas? Com quem você brincava? Quando foi o seu primeiro dia de aula? (procure lembrar o seu primeiro dia de aula, caso não seja possível, fale do que você consegue lembrar) Como era a sua professora ou professor? (procure lembrar-se de um professor ou professora que marcou a sua vida com exemplos positivos ou negativos). E sua escola? (procure lembrar-se de uma escola que tenha marcado a sua memória: a sala de aula, a direção, os funcionários). Você lembra quem eram os seus amigos? (procure lembrar-se dos amigos que marcaram a sua vida escolar)? Com que idade começou a trabalhar e qual o seu primeiro trabalho? (fale de seu primeiro trabalho) Como você se divertia? O que gostava de fazer? (fale das opções de diversão na sua infância ou adolescência e quais você dava preferência).

\section{ESTRATÉGIAS}

- Exposição de vídeo visando instigar as memórias da infância

- Fornecer material para que os alunos expressem as suas memórias.

\section{RECURSOS MIDIÁTICOS}

- Vídeo:http://www.midiatotal.net/2015/03/tema-de-abertura-de-sete-vidas.html

- Projeções de fotografias das Regiões Administrativas 


\section{ATIVIDADES}

- Expressão das memórias a partir de desenhos, colagem, música, fotografia, história em quadrinho, redação e/ou outras ferramentas disponíveis. 


\section{ANEXO IV - Plano de trabalho/Aula - Lugares de lembrar da cidade e sua inserção na cidade}

TEMA:

- Lugares de lembrar da cidade e sua inserção na cidade

\section{OBJETIVO GERAL:}

- Ativar a memória dos alunos sobre suas vivências com a comunidade.

\section{ESPECÍFICOS:}

- Provocar as lembranças das experiências dos alunos na escola.

- Incitar as memórias das experiências na Igreja.

- Estimular as lembranças das experiências com a vizinhança.

\section{ESTRATÉGIAS}

Os alunos serão instigados a refletir sobre as seguintes questões: Quais as dificuldades, contradições, ansiedades e aspirações você evidencia no espaço da cidade? (observe o espaço da cidade: o que você ver como dificuldade, que contradições você identifica e as ansiedades e expectativas dos moradores de sua comunidade). Faça uma autorreflexão no que se refere às atitudes adotadas na comunidade em que vive. (você se sente uma pessoa comprometida na sua comunidade). Como você identificar o seu comprometimento nestes espaços?

\section{RECURSOS MIDIÁTICOS}

- Vídeo: Bola de meia, bola de gude. Disponível em https://www.youtube.com/watch?v=-F_kKRmiHAw

- Projeções de fotografias das Regiões Administrativas

- Projeções de fotografias diversas escolas de Brasília

\section{ATIVIDADES}

- Expressão das memórias a partir de desenhos, colagem, música, fotografia, história em quadrinho, redação e/ou outras ferramentas disponíveis. 
ANEXO V - Plano de Trabalho/Aula - Lugares de sonhar: perspectivas futuras

TEMA:

- Lugares de sonhar: perspectivas futuras

\section{OBJETIVO GERAL:}

- Identificar os sonhos e perspectivas dos alunos

\section{ESPECÍFICOS:}

- Ativar os sonhos dos alunos com perspectivas positivas.

- Instigar a discussão de participação popular no governo da cidade.

\section{ESTRATÉGIAS:}

Os alunos serão instigados a pensar: Como seria uma cidade ideal? Qual a sua estrutura organizacional (procure contemplar os seguintes aspectos: a igualdade de condições nessa cidade, como ela seria governada e como seria a autonomia e valorização de seus moradores).

\section{RECURSOS MIDIÁTICOS:}

- Vídeo: Cidade

Ideal (Chico

Buarque

$\mathrm{e}$

Cia)

https://www.youtube.com/watch?v=wa3nq8Qbmug

- Video: O telefone é muito pouco (Renato Matos e Cássia Eller) disponível em https://www.youtube.com/watch?v=9IP8pPi10n8

- Vídeo: Linha do Equador (Caetano Veloso) disponível em https://www.youtube.com/watch?v=8WUtiF49eek

- Projeções de fotografias das Regiões Administrativas

\section{ATIVIDADES:}

- A pesquisadora apresenta um desenho de uma árvore em um papel oficio A 4. 


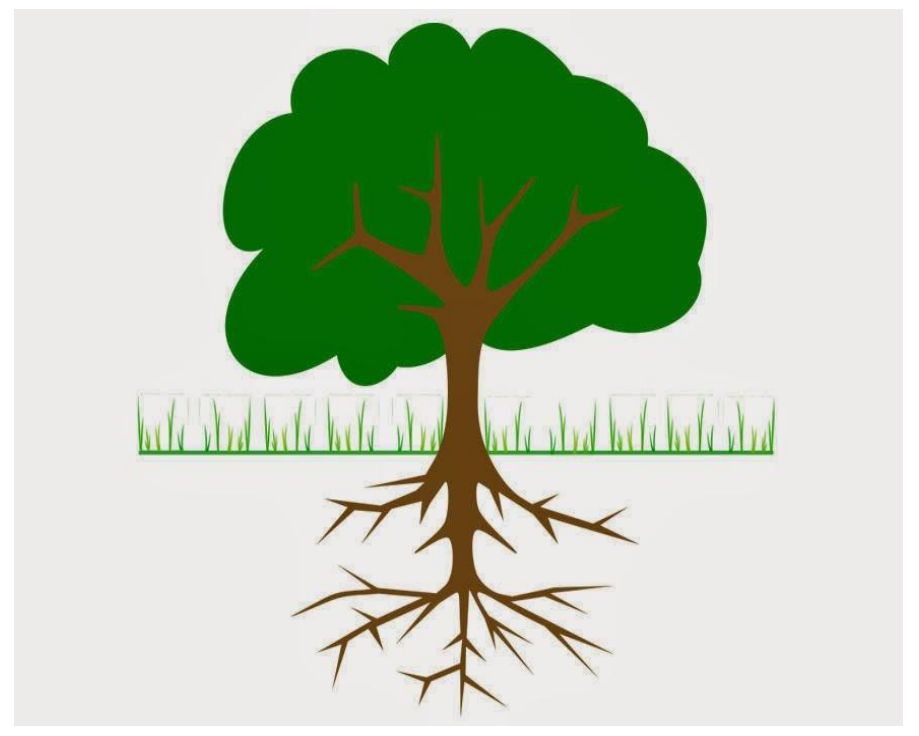

- Os alunos devem colocar na copa da árvore um sonho, um desejo, um objetivo ou um projeto de vida que pretende realizar.

- Em seguida os alunos devem escrever ao lado das raízes em que está firmado (em Deus, na família, nos amigos, na capacidade individual de realizar as suas ações, na perseverança, autoestima etc).

- No tronco os alunos devem escrever algumas ações para concretizar o que foi sonhado e/ou projetado. 


\section{ANEXO VI - TERMO DE AUTORIZAÇÃO DE USO DE FOTOGRAFIA E PRODUÇÃO EM ARTES}

Nome do autor:

RG:

Órgão Emissor:

e-mail:

Neste ato, e para todos os fins em direito admitidos, autorizo a MARGARIDA HELENA CAMURÇA MARTINS, mestranda em Arte da Universidade de Brasília - Instituto de Artes, matricula 15/0066597, a utilização com os devidos creditos de fotografias e produções de artes em caráter gratuito, exclusivamente para fins acadêmicos da pesquisa de mestrado sobre Narrativa Visual dos Alunos de Educação de Jovens e Adultos na Perspectiva da Cultura Visual.

Da minha autoria

De outros autores em que eu apareço

Estas fotografias e produções em artes poderão ser exibidas em exposições finais da referida pesquisa de mestrado, em publicações de artigos, assim como disponibilizadas seminários, congressos ou simpósios, na apresentação audiovisual, em exposições externas, e, em banco de imagens resultantes da pesquisa, sempre em âmbito acadêmico fazendo-se constar os devidos créditos.

A mestranda fica autorizada a executar edições e montagem de fotos, conduzindo as reproduções que entender necessárias, bem como a produzir os respectivos materiais de comunicação, respeitando sempre os fins estipulados.

Por esta ser a expressão da minha vontade declaro que autorizo o uso acima descrito.

Brasília, de de

Assinatura

Pesquisa: Narrativa Visual dos Alunos de Educação de Jovens e Adultos na Perspectiva da Cultura Visual. Pesquisadora: Margarida Helena Camurça Martins - Matricula UnB: 15/0066597

Telefone para contato: (61) 9908-9887 e (61) 3202-2297- e-mail: camurca7@ gmail.com. 


\section{ANEXO VII - TERMO DE CONSENTIMENTO LIVRE E ESCLARECIDO - TCLE}

$\mathrm{O}(\mathrm{a})$ Senhor(a) está sendo convidado(a) a participar da pesquisa: Narrativa Visual dos Alunos de Educação de Jovens e Adultos na Perspectiva da Cultura Visual.

O objetivo desta pesquisa é: apreender as narrativas visuais dos alunos da Educação de Jovens e Adultos sobre o espaço urbano que vivem. O(a) Senhor(a) receberá todos os esclarecimentos necessários antes e no decorrer da pesquisa e lhes asseguramos que seu nome não aparecerá, sendo mantido o mais rigoroso sigilo através da omissão total de quaisquer informações que permitam identificá-lo(a).

A sua participação será através de um de questionário que o(a) Senhor(a) deverá responder como aluno(a), na data ___________ Informamos que o(a) Senhor(a) pode se recusar a responder qualquer questão que lhe traga constrangimento, podendo desistir de participar da pesquisa em qualquer momento sem nenhum prejuízo para o(a) Senhor(a). Sua participação é voluntária, isto é, não há pagamento por sua colaboração.

Os resultados da pesquisa serão divulgados na Universidade de Brasília-UnB, podendo ser publicados posteriormente. Os dados e materiais utilizados na pesquisa ficarão sobre a guarda da pesquisadora.

Se o(a) Senhor(a) tiver qualquer dúvida em relação à pesquisa, por favor telefone para: Professora Orientadora Thérèse Hofmann Gatti, na Universidade de Brasília, telefone: (61) 3107-0299, nos horários: $8 \mathrm{~h}$ às $12 \mathrm{~h}$ e $14 \mathrm{~h}$ às $18 \mathrm{~h}$.

Brasília, de de

Assinatura

Pesquisadora: Margarida Helena Camurça Martins

Pesquisa: Narrativa Visual dos Alunos de Educação de Jovens e Adultos na Perspectiva da Cultura Visual. Pesquisadora: Margarida Helena Camurça Martins - Matricula UnB: 15/0066597

Telefone para contato: (61) 9908-9887 e (61) 3202-2297- e-mail: camurca7@gmail.com. 